EGG-PREP--8883

DE9 1006292

\title{
AN AIPPIROACH TO ESTIMATING RADIOLOGICAL RISK OF OFFSITE RELEASE FROM A DESIGN BASIS EARTHQL'AKE \\ FOR THE PROCESS EXPEFIMENTAL PILOT PLANT (PREPP)
}

Vlckle Lucero

Babette M. Meale

Danlel A. Reny

Anthony N. Brown

Publlshed September 1990

EG\&G Idahe, Inc.

Idaho Falls, Idaho 83415

Prepared for the

U. S. Department of Energy

Idoho Operations Office

Under DOE Contract No. DE-AC07-76ID01570 


\section{ABSTRACT}

In compllance with Department Of Energy (DOE) Order 6430.1A, a selsmlc analysis was performed on DOE's Process Experimental Pllot Plant (PREPP), a facility for processing low-level and transuranlc (TRU) waste. Because no hazard curves were avallable for the Idaho National Engineering Laboratory (INEL), DOE guldelines were used to estlmate the frequency for the specifled design-basis earthquake (DBE). A dynamic structural analysis of the building was performed, using the DBE parameters, followed by a probabillstlc risk assessment (PRA). For the PRA, a functional organization of the facillty equipment was effected so that top events for a representative event tree model could be determined. Bullding response spectra (calculated from the structural analysis), in conjunctlon with generls fragllity data, were used to generate fragllity curves for the PREPP equlpment. Using these curves, fallure probabilitles for each top event were calculated. These probabilltles were integrated into the event tree model, and accident sequences and respectlve probabilitles were calculated through quantiflcation. By combining the sequences fallure probabilitles with a transport analysis of the estimated airborne source term from a DBE, onsite and offsite consequences were calculated. The results of the comprehensive analysls substantlated the abillty of the PREPP facillty to withstand a DBE with negllgible consequence (l.e., estimated release was within personnel and environmental dose guldelines). 
The Department of Energy is evaluating varlous means for preparing mixed low-level and transuranic (TRU) waste for permanent storage. The Process Experimental Pllot Plant (PREPP) facllity, located at the Test Area North (TAN) site of the ldaho National Engineering Laboratory (INEL) and operated under contract by EG\&G Idaho, Inc., was bult as an experimental waste processing facllity to test the effectlveness of an incineration/grouting process. This process, which involves shredding, Incineration, off-gas treatment, and repackaging, is a proposed method for preparing waste to comply with the storage criterla at DOE's permanent storage site.

After PREPP was built, it was designated as a fully-operatlonal processing facillty and categorized as a non-reactor nuclear facillty. Additionally, since PREPP's design, DOE's design crlterla (DOE Order 6430.1) were also revised to recognize radloactive waste facllities as a separate category of non-reactor nuclear facillties with speclfic design requirements. One of the criterlon involves the abllity of the facillty to withstand a design basis earthquake (DBE). While the revised order was not intended to apply retroactively to existing facilltles, because PREPP had not yet begun to process radioactive materials, its quallflcation as an 'existing' facillty was questionable. Therefore, management determined that PREPP should meet the DBE crlterlon and a selsmic analysis ensued that utllized varlous probabillstlc rlsk assessment (PRA) techniques to determire the potentlal effects of a postulated DBE. The purpose of the selsmic analysis documented in this report is to substantlate design requirements and/or ldentify new requirer ents that will reduce risk assoclated with the facillty operailions.

While DBEs are generally determined through use of site-specific hazard curves, such curves for the INEL were not avallable when this effort began. Consequently, avallable DOE guidellnes were used to select the DBE used for the analysis efforts. As per these guidellnes, the recommended DBE for the INEL is represented by $0.14 \mathrm{~g}$ ground acceleration, with a return frequency of every 1000 years $(1 \mathrm{E}-3 / \mathrm{y})$.

Initlal accldent sequences were postulated based upon partitloning the facility into functional areas. The equipment within each area was then identifled with respect to location, elevation, function, and susceptibllity (l.e., fragillty) to a DBE. The function and design characteristics of the equlpment provided the basis for component fragillty selectlon. Because specific fragillty data do not exist for the PREPP components, PREPP components were equated to nuclear power plant components, for which component fragilitles have been documented. Integrating the PREPP-speciflc equlpment Information/evaluation with generic component fragility data, fragillty curves for each PREPP component were generated from which fallure probabillties were calculated.

Selsmic documentation indlcates that the most common equipment fallures from a DBE are support or anchor bolt fallures. For actual functional or structural failure of most equipment, considerably high ground accelerations must be experienced. 
Therefore, in order to postulate a release from the falled equipment, each support fallure probabillty was multiplled by a conservative 'breach' factor to estimate a (conservative) probability of fallure that could actually lead to release.

After fallure probabillties were estimated, event tree models were developed to represent each functlonal area. The probabilltles were Integrated into the event tree models for quantification of the postulated accident scenarlos. Because of the Importance of the heating, ventllation, and alr condlitoning (HVAC) system in mitigating potentlal environmental release of source term (glven an accident), the accident scenarlos were quantifled in two modes: success and fallure of HVAC, There were twelve dominant accldent sequences ( 6 with HVAC success; 6 with HVAC fallure) selected for further analysis with a consequence analysis.

In the consequence analysis, a transport model was developed based on the environment within the PREPP facllity (e.g., pressures, temperatures, heat structures, flow paths). The estimated failures and alrborne source term estlmated for each dominant accident sequence were entered as Initlal facllity conditions. The consequences of each of the dominant accident sequences were then calculated from time U-to-30 min to estimate maximum and final source term for each area within the facillty as well as for the environment. In addition to evaluating each functional area, two 'worst-case' sequerices were also postulated: maximum potential aerosol release of source term within the facillty from simultaneous fallures of all equipment, evaluated witn both success and fallure of HVAC.

Equipment fallures from earthquakes generally involve the anchor bolts or supports of equipment. However, It is unllkely that such fallures would constitute a release. Nevertheless, to reduce posslble equipment damage from a DBE, It was recommended that all anchor bolts and supports be strengthened to reduce the fallure probabilltiles. The fragillity analysis, however, also indicated that the quencher vessel was also suspectable to a DBE. As a result, further evaluation of the anchoring of this plece of equipment is recommendec.

Analysis of the two worst-case sequences' results indlcated that the maximum aerosol source term that could potentially be released to the environment was $2 \mathrm{mg}$ (which could only occur with HVAC fallure). Because this quantity is insignificant, no offsite analysis was deemed necessary. Additionally, examinatle $n$ of all transport analysis results showed all potential releases to be inconsequentlal within current dose guldellines. From these results, the capablity of the facllity to withstand a DBE without significant environmental impact was substantlated. 


\section{TABLE OF CONTENTS}



EXECUTIVE SUMMARY $\ldots \ldots \ldots \ldots \ldots \ldots \ldots \ldots \ldots \ldots \ldots \ldots \ldots$

1.0 INTRODUCTION $\ldots \ldots \ldots \ldots \ldots \ldots \ldots \ldots \ldots \ldots \ldots \ldots \ldots \ldots \ldots \ldots$

2.0 GENERAL METHODOLOGY $\ldots \ldots \ldots \ldots \ldots \ldots \ldots \ldots \ldots \ldots \ldots$

2.1 Structural Analysis and Response $\ldots \ldots \ldots \ldots \ldots \ldots \ldots \ldots \ldots$

2.2 Rlsk Assessment Methodology $\ldots \ldots \ldots \ldots \ldots \ldots \ldots \ldots \ldots$

2.2.1 Plant Famlliarization $\ldots \ldots \ldots \ldots \ldots \ldots \ldots \ldots \ldots, \ldots$

2.2.2 Plant Walkdowns ......................... 6

2.2.3 Accldent Scenarlo Postulation $\ldots \ldots \ldots \ldots \ldots \ldots \ldots \ldots, 6$

2.2 .4 Systems Analysls ........................, 6

2.2 .5 Component Fraglilty Determination ..............., 6

2.2.6 Final Accldent Sequence/Event Tree Model

Development . ......................... 7

2.2.7 Facillty Damage State Evaluation $\ldots \ldots \ldots \ldots \ldots \ldots \ldots, 7$

2.2 .8 Onsite Consequence Analysis $\ldots \ldots \ldots \ldots \ldots \ldots \ldots \ldots 7$

2.2 .9 Offisite Consequence Analysls $\ldots \ldots \ldots \ldots \ldots \ldots \ldots \ldots$

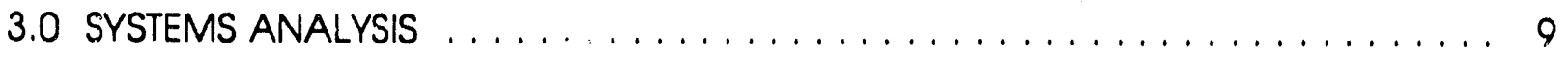

3.1 Introduction $\ldots \ldots \ldots \ldots \ldots \ldots \ldots \ldots \ldots \ldots \ldots \ldots, \ldots \ldots \ldots$

3.2 Assumptions $\ldots \ldots \ldots \ldots \ldots \ldots \ldots \ldots \ldots \ldots \ldots \ldots \ldots \ldots, \ldots \ldots \ldots$

3.3 System Equipment Analysis $\ldots \ldots \ldots \ldots \ldots \ldots \ldots \ldots \ldots \ldots$

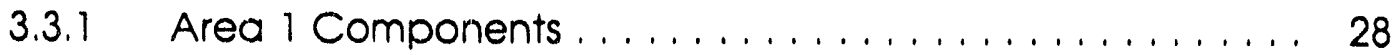

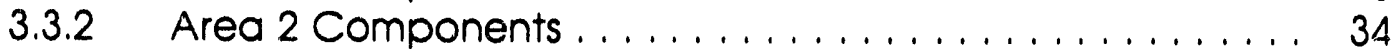

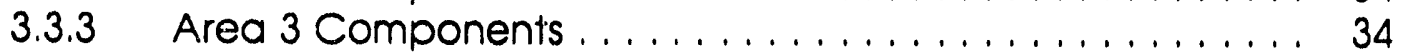

3.3.4 Area 4 Components ......................., 43

3.3.5 Area 5 Components ............................ 45

3.3.6 Area 6 Components ........................... 45

3.3.7 Area 7 Components ......................... 50

3.3.8 Area 8 Components ............................. 50

3.3.9 Area 9 Components ........................... 50 


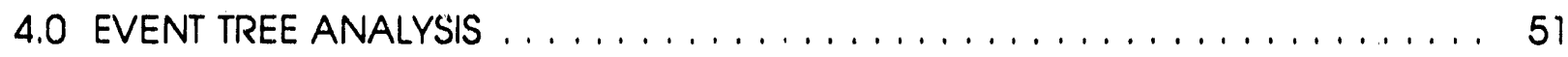

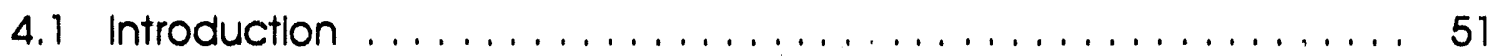

4.2 Accldent Scenarlo Development ................... 51

4.3 Dominant Accldent Sequences ......................, 51

5.0 CONSEQUENCE ANALYSIS $\ldots \ldots \ldots \ldots \ldots \ldots \ldots \ldots \ldots \ldots \ldots$

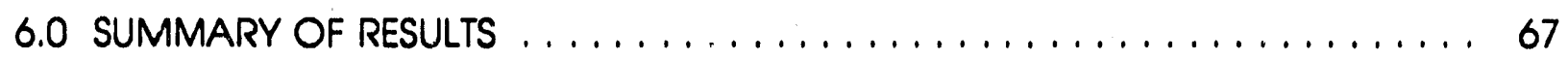

7.0 CONCLUSIONS AND RECOMMENDATIONS $\ldots \ldots \ldots \ldots \ldots \ldots \ldots . \ldots 75$

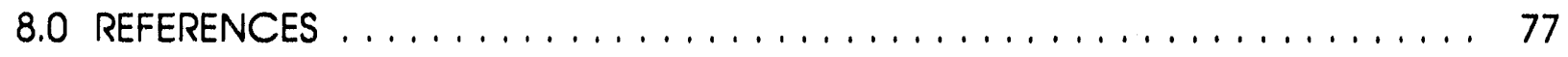

APPENDIX A--COMPONENT FRAGILITY DATA $\ldots \ldots \ldots \ldots \ldots \ldots \ldots \ldots$ A-I

APPENDIX B-AREA EVENT TREES $\ldots \ldots \ldots \ldots \ldots \ldots \ldots \ldots \ldots \ldots \ldots \ldots$ B-1

APPENDIX C--TRANSPORT DATA PLOTS $\ldots \ldots \ldots \ldots \ldots \ldots \ldots \ldots \ldots, \ldots \ldots \ldots$ 


\section{LIST OF FIGURES}

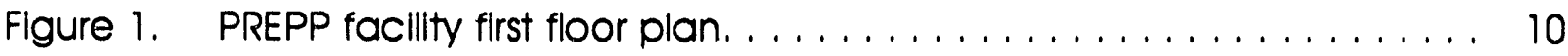

Flgure 2. PREPP facllity second iloor plan. . . . . . . . . . . . . . . 11

Flgure 3. Simplifled schematlc of the feed conveyor. . . . . . . . . . . . 32

Figure 4. Simplifled schematic of the rotary kiln and SCC . . . . . . . . . . 33

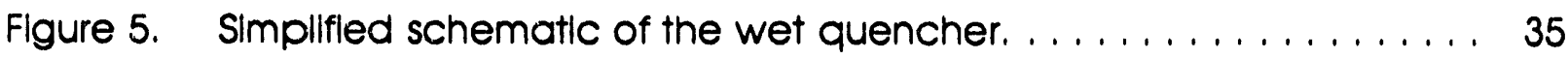

Figure 6. Simplifled schematic of the venturl scrubber. $\ldots \ldots \ldots \ldots \ldots, 36$

Figure 7. Simplifled schematlc of the entrainment ellminator. . . . . . . . . 37

Figure 8. Simplifled schematic of the mist ellminator. . . . . . . . . . . . . 38

Figure 9. Simplifled schematic of the surge recycle tank. . . . . . . . . . . 39

Figure 10. Simplifled schematic of the sludge tanks. . . . . . . . . . . . . 40

Figure 11. Simplifled schematic of the surge recycle drain tank. . . . . . . . . 4 4

Figure 12. Simplifled schematic of the emergency drain tank. . . . . . . . . 42

Figure 13. Simplified schematlc of the dlscharge conveyor. . . . . . . . . . . . 44

Flgure 14. Simplified schematlc of the trommel hopper. . . . . . . . . . . . 46

Figure 15. SImplified schematlc of the fines hoppers and blender tanks. . . . . 47

Figure 16. Simplified schematic of the fines weigh tank. . . . . . . . . . . , 48

Figure 17. Simplifled schematlc of the grout mixer tank. . . . . . . . . . . . . . 49

Flgure 18. Consequence of postulated worst-case fallure with HVAC success. 69

Figure 19. Consequence of postulated worst-case fallure with HVAC fallure. , , 72 


\section{LIST OF TABLES}

Table 1. PPEPP area designations $\ldots \ldots \ldots \ldots \ldots \ldots \ldots \ldots \ldots, \ldots \ldots \ldots$

Table 2. PREPP bullding spectra $\ldots \ldots \ldots \ldots \ldots \ldots \ldots \ldots$

Table 3. PREPP component fraglilty summary . . . . . . . . . . . . . . . . . . 29

Table 4. PREPP component fragllity values $\ldots \ldots \ldots \ldots \ldots \ldots, \ldots \ldots, \ldots, \ldots, \ldots$

Table 5. Accldent scenario and release frequency summary with HVAC success .................................... 53

Table 6. Accldent scenarlo and release frequency summary with HVAC

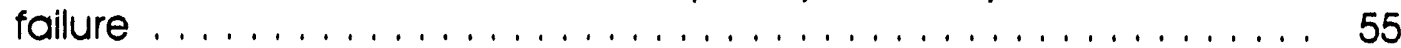

Table 7. Source term estimates $\ldots \ldots \ldots \ldots \ldots \ldots \ldots \ldots \ldots \ldots \ldots$

Table 8. PREPP control volumes . . . . . . . . . . . . . . . . . . . . . . . . . 59

Table 9. Transport results for HVAC success Accldent Scenarin 1. . . . . . . . 6 61

Table 10. Transport results for HVAC success Accident Scenarlo $2 \ldots \ldots . . .61$

Table 11. Transport results for HVAC success Accident Scenarlo $3 \ldots \ldots, \ldots .62$

Table 12. Transport results for HVAC success Accident Scenarlo $4 \ldots \ldots \ldots . .62$

Table 13. Transport results for HVAC success Accident Scenario $5 \ldots \ldots \ldots .63$

Table 14. Transport results for HVAC success Accident Scenario $6 \ldots \ldots . \ldots .63$

Table 15. Transport results for HVAC fallure Accident Scenario 1 . . . . . . . . . 64

Table 16. Transport results for HVAC fallure Accldent Scenario $2 \ldots \ldots \ldots$. . . . . 64

Table 17. Transport reuslts for HVAC fallure Accident Scenario $3 \ldots \ldots \ldots . .665$

Table 18. Transpurt results for HVAC fallure Accident Scenarlo $4 \ldots \ldots \ldots \ldots 65$

Table 19. Transport results for HVAC fallure Accident Scenario $5 \ldots \ldots \ldots \ldots 60$

Table 20. Transport results for HVAC fallure Accldent Scenario $6 \ldots \ldots . . . . .666$ 


\subsection{INTRODUCTION}

The Process Experimental Pllot Plant (PREPP) facillty, located at the Idaho National Engineering Laboratory (INEL), is operated under contract by EG\&G Idaho, Inc. It was bullt as an experimental transuranlc (TRU) waste processing faclity to prepare TRU waste, in various solld forms, for permanent storage at the Department of Energy (DOE) permanent storage site. In order to meet the permanerit storage criteria, the waste undergues a process of incineration followed by cement grouting solldification.

The PREPP facillty is bullt and operatlonal, but still undergoing pre-operational testing and development. Efflclency of the Incineration process design requirements and supporting functions, and recommended modifications for maintaining confinement control are being evaluated and impiemented. The seismic effort documented in this report is one part of the overall probabillstic risk assessment (PRA) that is belng used as a tool for substantlating the design requirements and;or identifying new requirements that will reduce risk assoclated with the facillty operations.

The PREPP faclilty is housed within a previously constructed bullding, TAN 607. Both bulldings were designed and constructed using Unlform Bullding Code (UBC) criterla which address seismic structural requirements. At the time of the design, DOE design criteria (DOE Order 6430.1) did not encompass radloactlve waste processing facillitles. Receni revision of the DOE Order 6430.1A (Ref. 1) recognizes radloactive waste facilities us a separate category of non-reactor nuclear faclilties. Under this current crlterla, PRE:PP Is classifled as a "Radloactlve Solld Waste Faclitty."

The revised oroar is not intended to apply retroactlvely to existing facillties, however, since PREPP has not started processing radloactlve materials its quallification as an existing faclllty $\mathrm{ma}$; be questloned. Also, without performing analyses to current crlterla, there would , ylways be a questlon regarding the ability of the existing facillties to meet current DOE standards for safety, both to the publlc and the employees, in the event of a design basls selsmic event. For these reasons dynamic seismic anaiyses were performed on the PREPP and TAN 607 bullding structures (Reli. 2 and 3) in accordance with DOE Order 6430.1A. Thls work was extended to provide dynamic spectra for use in design of the process system and facillty modifications currently in progress and for performing seismic risk assessment and consequence analysis assoclated with PREPP radloactive operations. This report presents the methodology and results of the risk assessment and consequence analysis performed as part of the PREPP selsmic analysis. 
Section 2.0 presents the methodology by which the analysis was performed. Included in this section are a summary of the structural analysls of the two bullding structures encompassing the facillty and descriptlons of the dlfferent tasks accomplished in performing the risk assessment.

Systems analysls tasks are described in Section 3.0. At the first of this section, a brlef overview of the facllity layout and assumptions used in the analysis are presented. The remainder of the section provides detalled accounts of the analysis for each of the nine areas within the facillty, including equipment descriptions, functlons, and locations; schematic representations of the major equipment; spectral accelerations at various locations within the facllity; and fallure probabllitles of the equipment as estimated from fraglity curves (provided in Appendlx A).

Following the Syster is Analysis section is an Event Tree Analysis sectlon (Section 4.0). Again, the section commences with an introduction of the event tree process and its specific application to the analysis. Accident scenarlo development and dominant accident sequence identiflcation are also presented in this section.

Section 5.0 presents the consequence analysis, including conclse descriptions of the computer model parameters and results. The results as presented in this sectlon and the previous analysis tasks are summarized in Section 6.0. Based on the results, conclusions and recommendations were made and are presented in Section 7.0. The final section, Sectlon 8.0. provldes a reference listing as cited throughout the report.

In addition to the main report, three appendlces are also provided: Appendlx $A$, Component Fragllity Data (in support of Section 3.0); Appendix B. Area Event Trees (supporting Section 4.0); and Appendlx C. Transport Data Plots, supporting the Consequence Ar.alysis (Section 5.0). 


\subsection{GENERAL METHODOLOGY}

This report provides the results of a probabillstlc assessment of the likellihood and magnitude of a radloactive materlal release from the PREPP facllity due to a Design Basis Earthquake (DBE). The analysis was limited to an assessment of the likellihood and magnitude assoclated with only the single selsmic level of the DBE event. However, the point estimate at the DBE level event would envelope or bound the llkellhood of release consequences assoclated with any selsmlc event of lower intensity but, would not provide any risk information about selsmic events of higher intensity than the DBE.

There are three particular selsmic fallure modes that lead to releases of material at PREPP. One, failure and collapse of the bullding structure that results in release of entire bullding inventory; two, significant overdrift of bullding structure that leads to fallure of all confinement equipment and component mounting fallures that may lead to breaches and releases; and three, Independent fallure of confinement equipment and components that may lead to breaches and releases. The total llkellihood and magnitude of release due to the DBE event would be the sum of these three fallure modes.

The first fallure mode, bullding collapse, is a functlon of the bullding structural integrity and therefore is a function of the results of the bullding structural analysis. The PREPP structural analysis results showed significant overstressing of the first fluor crossbracing connectlons which lead to probable (greater than $50 \%$ llkellihood) collapse of the entire structure. GIven the DBE freqL ency of occurrence is IE-3 per year, the PREPP structure as it stands would have a $5 \mathrm{E}-3$ llkellhood of collapse and release of a significant amount, if not all, of the source term material ronfined within the PREPP structure. However, flxes for the overstressen crossbracing connections have been Identifled and are planned. With the flxes accomplished, all of the structural stresses would be below the allowable limits, which would then provide a high confldence (about 99.9\%) that the structure would not collapse at the DBE selsmlc level event. Glven the fixes are accomplished, then the likellihood of the structural collapse fallure mode would be reduced to below $1 \mathrm{E}-5$ and could be as low as $1 \mathrm{E}-6$ per year.

The second fallure mode, bullding overdrift and equipment and component mountings fallure, can be determined by the bullding drift calculated in the bullding structural analysis. The general rule on allowable drift before component mounting fallure occurs is .01 of the bullding height. For the PREPP buliding .01 of the bullding 
helght is approximately 4 inches. The bullding structural analysis calculated the maximum bullding drift at the maximum helght of the bullding, the roof, to be 0.82 inches at the point the bullding structure falls and collapse occurs. Therefore, bullding collapse would occur prior to the overdrift component fallure mode, which makes this fallure mode inconsequential.

The third fallure mode, Indlvidual component fallures, are analyzed and results reported within this report. The analysis results identified six release sequences composed of five Indlvidual confinement equipment fallures and one simultaneous fallure of two components. All of the sequences lead to releases within the PREPP bullding. These releases within the PREPP bullding occur with the bullding structure and integrity in tact and with the bullding confinement HVAC system elther operable or falled. The sum of the likellhood of sequences leading to releases within the bulldirig with the building HVAC operable is $8.8 \mathrm{E}-5$. The amount of source term released within the bullding is considered to be signiflcant however, a bullding transport analysis shows almost none is released from the bullding to the outside environment. The sum of the llkellihood of sequences leading to releases within the bullding with the bullding HVAC Inoperable is 8.7E-6. The amount of source term released within the buliding is the same and the bullding transport analysis shows that even with the bullding HVAC falled, very llttle is released from the bullding to the outside environment.

Based on the amount of materlal released within the bullding and outside of the bullding, a bounding consequence assessment was performed to show the offsite consequences to the publlc to be within acceptable guldellne limits. However, the analysis also shows there are high consequences (above guidellnes) cassociated with personnel exposure to releases within the bullding and at the TAN slte.

Because no formal seismic evaluation had been performed for PREPP prior to this effort, it was necessary to develop an approprlate methodology specific to the facillty. This required an in-depth revlew of avallable selsmic (probabilistic) analysis methodologies and design criteria (Refs. 4-15), selsmic fragillty dota (Refs. 16-20), and varlous other documents and articles relevant to risk assessment and/or seismic analysis (Refs. 21-26). Identiflcation and review of avallable plant-speciflc documentation (Refs. 27-15) was also conducted in order to tailor the developed approach to PREPP.

A seismic risk analysis generally consists of five speciflc tasks: (1) seismic hazard analysls, (2) plant walkdowns, (3) systems analysis, (4) equipment frogilty evaluation, 
and (5) release frequency evaluation. However, the unlqueness of the PREPP facllity and the unavallabllity of site-speciflc hazard curves ard selsmic evaluation data for the PREPP equipment dictated a diverslon from the typlcal methodology. The methodology anplied to the PREPP selsmlc analysls effort is presented in the following sect'ons.

As part of a selsmlc hazard analysls, a design basis earthquake (DBE) must be deternined. While this is generally performed through use of site-speciflc hazard curves, such curves were not avallable when the PREPP seismlc effort began. Consequently, the Department of Energy's (DOE's) guldelines as presented in Reference 46 were used to select a DBE. As per these guidellnes, the recommended DBE is represented by $0.14 \mathrm{~g}$ ground acceleration, with a return frequency cf every 1000 years (IE-3/Yr).

\subsection{Structural Analysis cind Response}

A dynamic structural analysls of both the PREPP and TAN 607 structures (Refs. 2 and 3) was performed. Following the guidellnes provided in Reference 45, two loadings were considered: deadw'elght (l.e., weight forces assoclated with, the entire mass of the structure) and earthquake. Using a $7 \%$ damped spectra, the seismlc forces in the PREPP structure was evaluated in a response spectra analysls. The bullding structural response spectra was further expanded to create a two-dimenslonal stlck model with an artificial acceleration time history. Response spectra for locatlons within the faclilty were generated through a direct integration procedure which provided in-structure arceleration, time histories. (For more detalls on the in-structure response spectra, see Reference 47.)

\subsection{Rlsk Assessment Methodology}

\subsubsection{Plarit Famillarization}

Piant is,imilliarization consisted of several facillty tours and discussions with cognizunt facility personnel. Further, in-depth reviews of plant-specific documentation were conducted. information related to design criteria, design upgrades, plant operations, and administrative guldellnes were gathered durlig this task. Component and system functions were also researched. 


\subsubsection{Plant Walkdowns}

The purpose of the initial plant walkdown was to famillarize the analysts with the facillty layout and equipment locatlons. Subsequent walkdowns facilltated identiflcatlon of components that were potentially susceptlble to a DBE. Such susceptiblity was estimated based on equipment function, location, and orlentation. The walkdown process was repeated as necessary to evaluate equlpment fragllity and design upgrades, and to verify collected Information and assumptions.

\subsubsection{Accldent Scenario Postulation}

Combining the information collected during the walkdowns with other plant-speciflc data provided a basls for postulating Initial accident scenarios. Because icoms within the plant have relatlvely unlque, distinct functlons, one scenarlo was postulated ar each ruom. While thls approach provided a strong foundatlon for accldent sequence evaluation, it also generated more sequences than could be evaluated within the scope and timeframe of this effort--in fact, more than were necessary. Therefore, an in-depth systems analysis was initlated to approprlately reduce the number of sequences and to effectlvely generate final scenarlos which would accurately represent the facillty. A detalled description of the accident scenario development and modeling is presented in Section 4.0.

\subsubsection{Systems Analysls}

The systems analysls consisted of thoroughly examining system documentation, drawings, and schematics of the plant equlpment. Through this in-depth review, the varlous functions in the PREPP process were identifled aild the facllity was appropriately grouped into a more reasonable number of areas. In this regrouping, the primary functions of the faclity were each uniquely represented in one area. $A$ more detalled discussion of this task is presented in Section 3.0.

\subsubsection{Component Fragility Determination}

Component fragillty is an estimate of the condltional probability of component fallure given a selsmls event. Cetermination of the component fragilltiles entalled gathering information concerning the size, shape, and structural support for each component. Speciflc fragillity data do not exlst for the PREPP components; and the tests required to determine such data are beyond the scope of this effort. However, component fragilitles have been determined and documented for simliar equipment as found in 
nuclear pcwer plants. Therefore, using the guldelines documented in Reference 18 , each PREPP component was matched to a nuclear flant component with similar structural charcicteristics. The parameters of the nower plant component frum Reference 18 weis then used to generate a distribution to represent probabillty of component fallure with respect to the acceleration at the component's location. Section 3.0 provides more speciflc information on the methodology for determining PREPP component fraglittles.

\subsubsection{Final Accldent Sequence/Event Tree Model Developmeílt}

The next step in the analysis in'volved developing event tree models to represent the final accident sequences. Event tree analysls was chosen as the most approprlate PRA technique to systematlcally model selsmlc effects because of its abillty to address the sequentlal nature that is inherent in the consequences resuiting from a seismic event. A detalled discussion of the event tree modeling and analysis is presented in Section 4.0.

\subsubsection{Facllity Damage State Evaluation}

Determination of source term quantitles in each area and quantification of the event trees provide Input for this task. Dominant accident sequences were obtalned from the quantiflcation effort. Source term characteristics (e.g., airborne or llquld) and the quantity of the source term within the areas identlfled by the dominant sequences were then confirmed. This information was integrated with other area characteristics (e.g. . temperature, pressure, etc.) to determine the facillty damage state for each postulated dominant accldent event. The source term characteristics and quantitles and the resulting damage states for the PREPP analysls are presented in Section 4.0.

\subsubsection{Onsite Consequence Analysis}

For this analysls, the facllity was modeled as characterized by the damage states. The dominant accident sequences were analyzed indlvidually to determine the transport and dlspersion of the specifled source term within the facillty. Sectlon 5.0 presents speciflc Information and data relevant to the consequence analysis for the PREPP selsmic analysis. 


\subsubsection{Offsite Consequence Analysls}

Potentlal offsite radlological consequences for the postulated PREPP accident scenarios Ideiliffed by the event tree analysis were calculated in this task. The calculated doses represented committed effectlve dose equivalents (l.e., fraction of radlonuclides retained in the body for 50 years following the periad of intake). The PREPP-specific results of this portion of the selsmic effort are addresied in Section 5.C. 


\subsection{SYSTEMS ANALYSIS}

\subsection{Introduction}

PREPP Is a mult-level facillty comprised of two maln floors, two mezzanine floors, and a basement level or plt. Within this arrangement, some rooms are completely enclosed on one floor level, while others may encompass two or three different levels. Because of this unusual architectural design, the rooms as designated on the P\&IDs (Ref. 34) and shown in Flgures 1 and 2 were grouped Into more practical units. The purpose of this regroupling is twofold: (1) to minimize the total number of models needed to adequaiely represent the facillty and (2) to reflect the function of a particular area with respect to confinement and/or mitigation of a potentlal release. To accurately represent the distinct functions within the facillty, an in-depth revlew of the avallc.ble PREPP-speciflc documentation was performed. The newly-designated areas as derived from this revlew, Including designator (number and title), room numbers inclucied in the area, and a brlef description of the overall function of the area in terms of operations is provided as Table 1.

As summarized In Table 1, the PREPP facillty was dlvided into nine functlonal areas and two support areas. The nine functional areas are further described in the following subsections. The support areas (Areas 10 and 11), however, were not included in the detalled systems and event tree analyses but are described below.

Area 10 represents Zone $C$ areas which are used only for transport of sealed containers. All containers must be transported within slx inches of the floor at all times (see Assumption 10, Section 3.2). Although the selsmic inltiator could, feasibly, cause containers to fall from the transport enulpment, at this minimal distance no damage could be effected (Ref. 48). Additionally, in small enclosed rooms within this area (e.g. Ilft conveyors), It was considered equally incredible for movement caused by a DBE to cause any damage to sealed containers.

Area 11 !ncludes all areas that will not contain any waste (e.g., UPS, switchgear, corridors). While the rooms in this area may have implications as auxillary support and possible deterrent to the spread of a release, they have no significance from a release-source perspectlve. The addltional corrldors and/or alr locks have been incorporated in the transport analysis model, to determine accurate pathways for any releases modeled (See Section 5.0). 


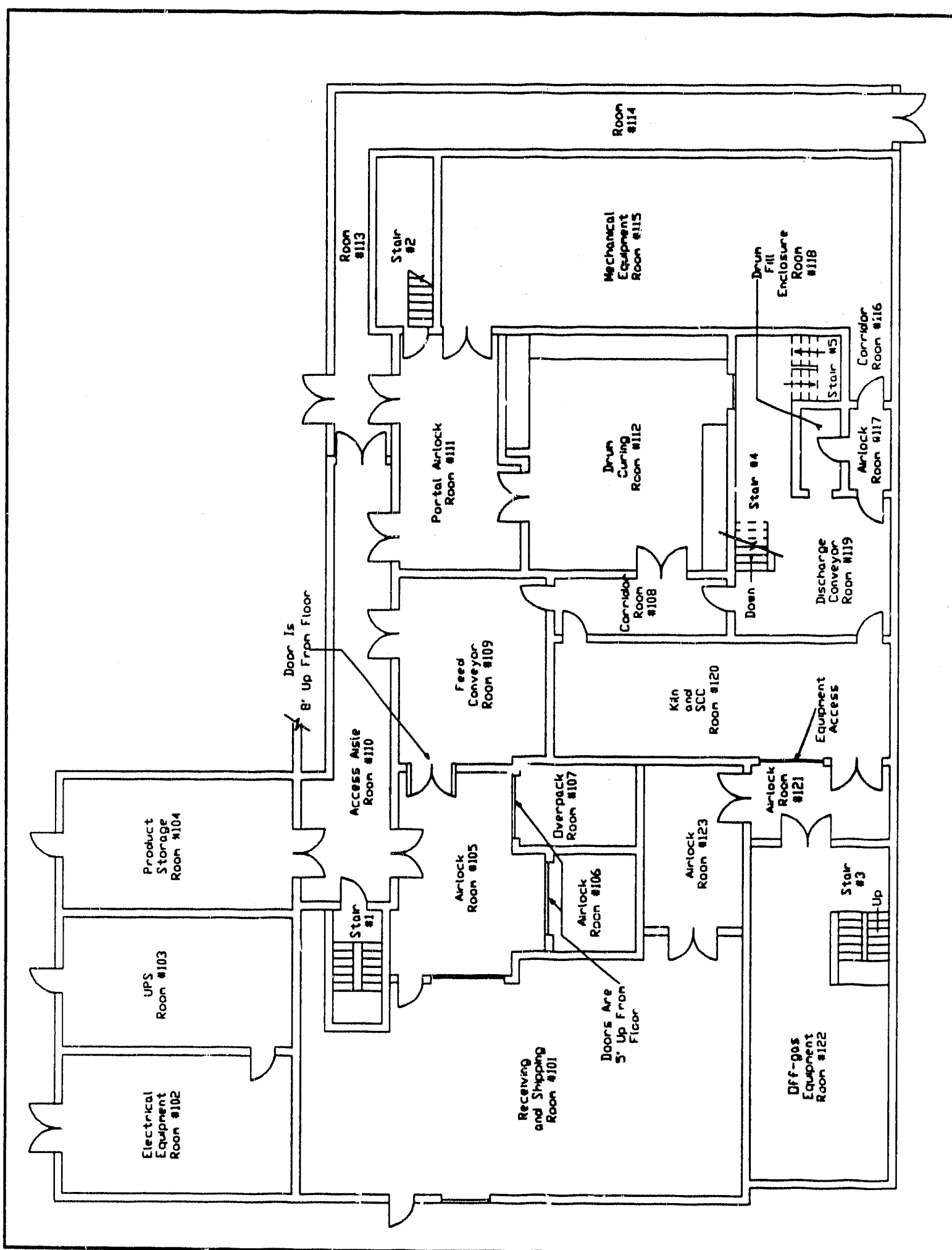

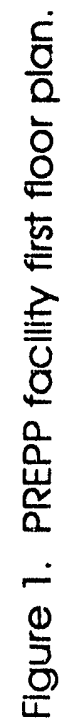




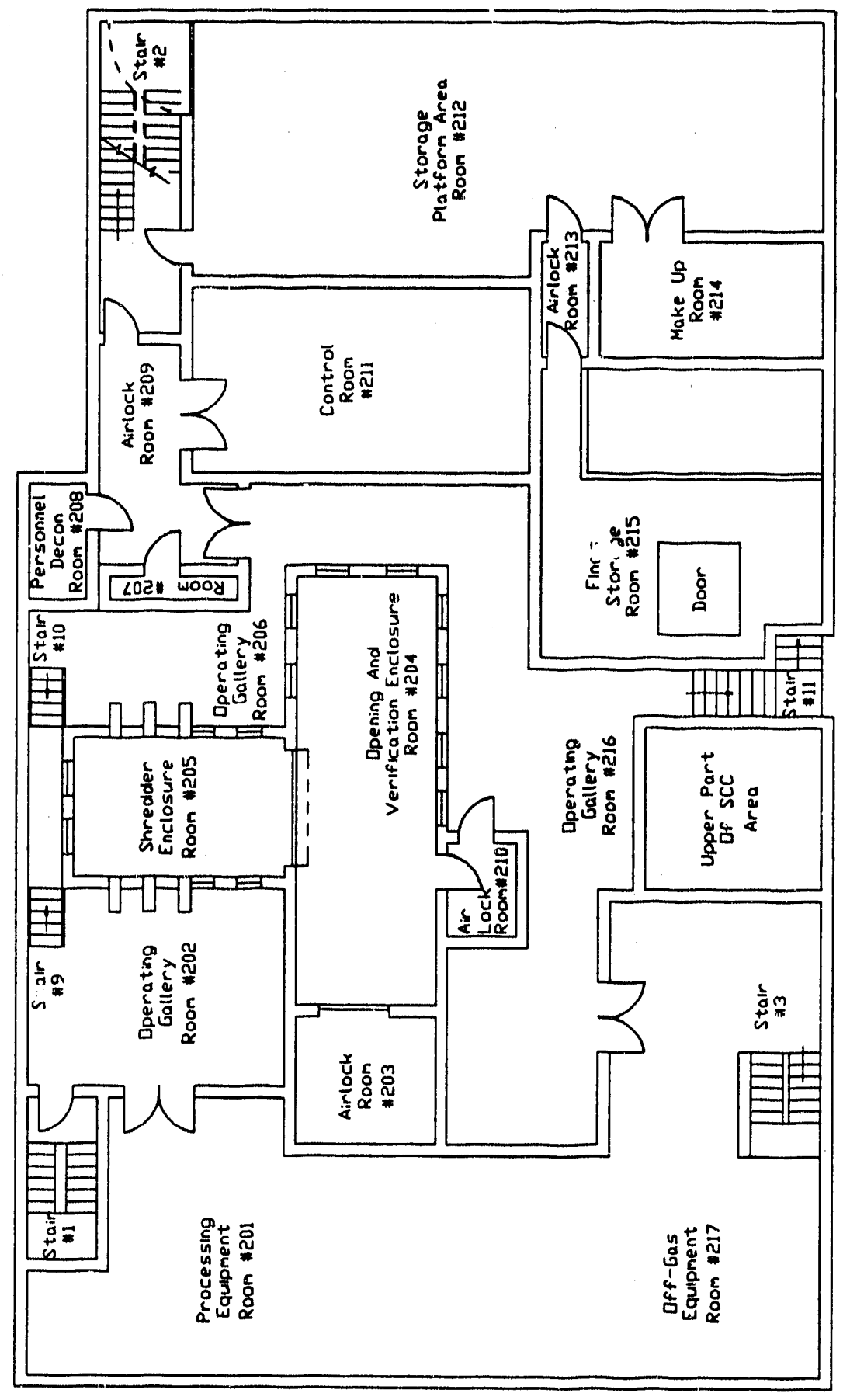

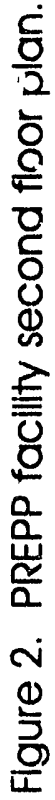


TABLE 1. PREPP AREA DESIGNATIONS

\begin{tabular}{|c|c|c|c|}
\hline $\begin{array}{l}\text { Area } \\
\text { Number }\end{array}$ & $\begin{array}{l}\text { Area } \\
\text { Name }\end{array}$ & $\begin{array}{l}\text { Room: } \\
\text { Included }\end{array}$ & $\begin{array}{l}\text { Area Function } \\
\text { and Equlpment }\end{array}$ \\
\hline 1 & Feed & $\begin{array}{l}109 \\
120\end{array}$ & $\begin{array}{l}\text { Waste feed and incineratlon. Includes } \\
\text { feed conveyor, kiln, arid secondary } \\
\text { combustion chamber (SCC). }\end{array}$ \\
\hline 2 & Off-Gas & 217 & $\begin{array}{l}\text { Processing off-gas, Includes wet } \\
\text { quencher }(W Q) \text {, venturl scrubber (VS) } \\
\text { entrainment eliminator (EE), and mist } \\
\text { ellminator (ME). }\end{array}$ \\
\hline 3 & Llquild & 122 & $\begin{array}{l}\text { Processing of the llquid by-product of } \\
\text { cleansing the off-gas. Includes Surge } \\
\text { Recycle Tank (SRT), SRT pump, sludge } \\
\text { tanks, sludge tank pumps, Surge } \\
\text { Recycle Drain Tank, and Emergency } \\
\text { Drain Tank. }\end{array}$ \\
\hline 4 & Solld & 119 & $\begin{array}{l}\text { Processing solld discharge from the killn. } \\
\text { Includes only the dlscharge conveyor. }\end{array}$ \\
\hline 5 & Fines & $\begin{array}{l}118 \\
119 \\
215\end{array}$ & $\begin{array}{l}\text { Processing the fines waste for mlxing } \\
\text { with the grout. Includes trommel } \\
\text { hopper, ash conveyor, fines hoppers, } \\
\text { fines tanks, and fines weigh tank. }\end{array}$ \\
\hline 6 & Filling & $\begin{array}{l}118 \\
119\end{array}$ & $\begin{array}{l}\text { Filling the drums with mixture of waste } \\
\text { and grout. Includes the drum being } \\
\text { fllled and drum enclosure. }\end{array}$ \\
\hline
\end{tabular}


TABLE 1. CONCLUDED.

\begin{tabular}{|c|c|c|c|}
\hline $\begin{array}{l}\text { Arec } \\
\text { Number }\end{array}$ & $\begin{array}{l}\text { Area } \\
\text { Name }\end{array}$ & $\begin{array}{l}\text { Rooms } \\
\text { Included }\end{array}$ & $\begin{array}{l}\text { Area Function } \\
\text { and Equipment }\end{array}$ \\
\hline 7 & Mixing & 215 & $\begin{array}{l}\text { Mixing the fines with grout for drum } \\
\text { storage. Includes only the grout mixer } \\
\text { tank. }\end{array}$ \\
\hline 8 & Curing & 112 & $\begin{array}{l}\text { Stirrage of flled drums. Includes the } \\
\text { stored drums only. }\end{array}$ \\
\hline 9 & HVAC & 115 & $\begin{array}{l}\text { HVAC provides negatlve pressure within } \\
\text { the PREPP facllity. Includes running } \\
\text { HVAC blower only. }\end{array}$ \\
\hline 10 & $\begin{array}{l}\text { Access } \\
\text { Ways }\end{array}$ & $\begin{array}{l}101,104 \\
105,106 \\
107,110 \\
11 \%, 121 \\
203,204\end{array}$ & $\begin{array}{l}\text { Areas through which waste can be } \\
\text { transported but is not processed. }\end{array}$ \\
\hline 11 & Corrldors & $\begin{array}{l}102,103 \\
108,113 \\
114,116 \\
117,202 \\
206,207 \\
208,209 \\
210,211 \\
212,213 \\
214,216\end{array}$ & $\begin{array}{l}\text { Areas where waste is never present } \\
\text { during normal operations. }\end{array}$ \\
\hline
\end{tabular}

${ }^{\circ}$ Rooms 201 and 205 have been excluded from the listing. Room 201 contains the HEPAS, exhaust fans, and facllity stack-release is assumed to occur prior to these components. Room 205 contains the shredder, which will always contain unconfined waste when in operation. 
Using the Table-1 regrouping, each area was evaluater' to determine actual physical confinement of the waste. Each plece of equipment providing such confinement was Identifled and evaluated as prevlously described in Section 2.6. Detalled descriptions of the equipment, presented by the Table ? area designations, are provided in Subsections 3.3.1 through 3.3.8. Included in each area description are structural attributes of the equipment contained within the area, accompanled by a simplifled schematic, and the respective functions or each major component identifled. The fragillty íor each major ccimponent (calculated from Reference 18 parameters) is also included in the descriptions.

In addition to physical confinement, the negative pressure boundary was examined. Two systems contribute to maintaining the negative pressure within the facillty: (1) the off-gas treatment system, and (2) the heating, ventllation, and air condltioning (HVAC) system. The HVAC system, however, is capable of malntaining the boundary without the off-gas. Therefore, the HVAC system (Area 9) was considered to determine success or fallure of the negatlve pressure boundary. The extent to which actual pressure boundarles within the facillty fall, given failure of the HVAC, and the effect of such fallures on offsite release are provided in the consequence analysis section (Section 5.0).

\subsection{Assumptions}

Because the PREPP facllity is stlll undergoing design changes, facllity-specific information on the process equipment as well as other process parameters was not avallable at the time of this analysis. Consequently, the following conservatlve assumptions were generated in order to provide some bounds for the analysis:

(1) The source term considereci consists of Plutonlum (Pu) and Amerlcium (Am).

Justification: References 46 and 49.

(2) Pu is characterized by the following attributes:

Oxide in form.

Justiflcation: In addltion to being ine probable form of Pu antlclpated, this assumption was needed in order to bound the analysls (Ref. 49-50).

Average partlcle size of $20 \mu \mathrm{m}$.

Justiflcation: This size is probable and presents a potential health and safety hazard (Ref. 49). 
Always attached to partlculate.

Justification: References 49-51.

Quantity $=70 \mathrm{~g} / \mathrm{ft}^{3}$ ash.

Justification: References 50-52.

Neallgible amount of Pu in coarse materlals.

Justlfication: References 49-52.

(3) Amerlclum (Am) is characterized by the following attributes:

Amount of Am is determined to be $2.5 \mathrm{mg}$ per gram of Pu generated over 25 years, plus an initial $100 \mu \mathrm{g}$ per gram of Pu present at time container was fllled.

Justlilcation: Reference 49-52.

Am will exist in the same form and react as Pu (e.g., particle size, attached to partlculate).

Justiflcation: Reference 49.

(4) Maximum storage for varlous equlpment anticlpated in normal operations is as follows:

Fines Blenders-25 $\mathrm{fi}^{3}$ Inventory assumed.

Justiflcation: Each fines blender has the capaclty for $17 \mathrm{ft}^{3}$. Under normal operating condltions, one blender would be used for drum filling and the other would be in recelving mode. Therefore, one could be full $\left(17 \mathrm{ft}^{3}\right)$, and the other beginning to recelve. Filling is expected to occur when the second hopper begins recelving (or before). Consequently, as the second hopper begins to flll, the full one is being depleted (References 49-52).

Trommel Hopper-3 $\mathrm{ft}^{3}$ inventory assumed.

Justfflcation: The hopper has recently been redesigned so that during normal operations there is $1 \mathrm{ft}^{3}$ in the monltoring area and $<4 \mathrm{ft}^{3}$ in the remalnder of the hopper. Whille not antlclpated during any normal operating conaltions, the hopper could feaslbly hold up to $8 \mathrm{ft}^{3}$. (This maxirnum quantlty may be used in performing sensitivity analyses once the selsmlc analysis is completed.)

(References 49-52.) 
Grout Mixer-3.5 $\mathrm{ft}^{3}$ inventory, consisting of fines ( $30 \%$ ), sand/sludge solld $(-31 \%)$, cement $(\sim 25 \%)$, and slu $\mathrm{ge} / \mathrm{liquid}$ $(\sim 14 \%)$.

Justiflcation: References 49-52.

Sludge Tanks--40 gal (3 tanks) Inventory.

Justification: Normal operating condltions could dictate that one tank was filled, being depleted for grouting; one tank is sparging, walting to be used for grouting: and one is being filled from off-gas. In this conilguration, c maximum of two tanks (at $25 \mathrm{gal}$ each) could be full before one begins to empty for grouting. However, grouting depletes a tank much faster than the off-gas can fill one. Therefore, less than two full tan!'s is considered more reallstlc given the limiting operating conditions imposed by grouting requlrements (References 49-52).

(5) Offilte power is unavallable.

Justification: Reference 49.

(6) TAN and PREPP diesels initially avallable.

Justiflcation: Reference 49.

(7) Waste is not in drum fill room for longer than i hour, which corresponds to orie drum/h output (two grout batches).

Justification: Normal operation Involves grouting simultaneously with incineration and grouting continuously, Normal operating procedure also requires layering of waste: resultant mixture is $200 \mathrm{lb}$ fines, $350 \mathrm{lb}$ course, and $350 \mathrm{lb}$ grout. At this rate, solld waste will not remain In the drum fill enclosure longer than the time to fill one drum (Ref. 49). If, however, grouting is not performed simultaneously with Incineration, waste could feasibly remain in enclosure between 8 and 16 hours (References 49-52). Sensittilty analyses could be performed if further analysls were warranted. 
(8) On the average, total welght of waste after incineration is 25 percent of the orlginal weight; 15 percent of this goes tu off-gas, 21 percent goes into fines, and 64 percent goes to drum fill enclosure.

Justiflcation: References 49 and 52.

(9) Only the off-gas and fines contain signiflcant zuantlties of source term of Interest. Additionally, the source term of concern is that which is not suspended In the llqulds of the off-gas vessels but only that which has the potentlal to become alrborne.

Justification: Reference 49.

(10) Drums meet criteria of 49 CFR, which states that the drurns will not breach If dropped from elevation of four feet when the drums are fllled with 98 percent water (l.e., $500 \mathrm{lb}$ ) While thls crlterla is somewhat less rigorous than what the arums will actually be subjected to, transport equlpment regulations require that drums remain within 6 " of the floor. At this helght, the difference in the 49CFR testing and actual stress on the drums is insigniflcant.

Lustification: References 48 and 49.

(11) The ducting throughout the facillty is exceptlonally rugged because of the extensive welding of the joints, anchors, and supports.

Justification: Reference 49.

(12) The lines assoclated with the sludge tank pumps are small. Therefore, they are assumed to rupture with the pumps.

Justiflcation: Reference 49.

(13) The sumps are designed to hold 125 percent of total volume capacity of tr.e liquld in the four off-gas vessels.

Justiflication: Reference 49.

(14) For purposes of this analysls, the hydrocyclone separators and the sludge tanks are evaluated as one unit.

Justiflcation: Because of thelr connections and supports, both the sludge tank and its assoclated separator would have to fall, i.e.. It is highly Improbable that one could fall structurally without the other also falling. 
(15) The SCC is not evaluated for fallure because of the sturdiness of structure and mountings.

Justiflcation: Reference 49.

(16) The fragillty of the klln was based on the trapeze supports for the seals, the tle rods, and the firing hood bolting.

Justification: Reference 49.

(17) While the feed conveyor is more rugged than tanks, It was conservatlvely evaluated with tank parameters.

Justiflcation: To determine exact fragillty of the conveyor would be beyond the scope of this effort: therefore a conservative estlmate was used.

(18) Drum being filled was evaluated by the supports that lock it into place.

Justification: These supports are rated to full drum (statlc equivalent load) capacity. The clamps. selsmically rated for 0.38 horizontal and 0.25 vertical, are assumed to hold drum in place under DBE conditions (Ref. 48).

(19) Average number of drums in short-term storage were estimated to total 60.

Justiflcation: Reference 53.

\subsection{System Equipment Analysis}

The areas identifled in Table 1 will be addressed in the following sections. Included in the dlscussions will be concise descriptions of the equipment in each area, supported with simplifled schematic representations of each major component identifled. A detalled equipment evaluation was performed to identify the primary function of the equipment, as well as to confirm several other key atiributes: location, elevation, anchoring/bolting/supports, structure, and source term parameters. These equipment features were then organized for use in the component fragillty analysis.

Component fragllity was determined by integrating the inforrnation from the equipment evaluation task and References 18 and 47. From Reference 47, spectral accelerations in all three orthogonal directlons (see Table 2) were integrated using square root of the sum of the squares (SRSS) methodology. Using appropriate 
TABLE 2. PREPP BUILDING SPECTRA

\begin{tabular}{|c|c|c|c|}
\hline \multicolumn{4}{|c|}{ Greund Floor Spectro-.5\% Damping } \\
\hline \multicolumn{2}{|c|}{ Vertical } & \multicolumn{2}{|c|}{ Horizontal } \\
\hline atzs & (Gs) & OHz) & $(\mathbf{G})$ \\
\hline 0.001 & 0 & 0.001 & 0 \\
\hline 0.1 & 0.00969 & 0.1 & 0.01428 \\
\hline 0.242 & 0.05662 & 0.242 & 0.08344 \\
\hline 0.248 & 0.05947 & 0.248 & 0.08764 \\
\hline 0.253 & 0.06194 & 0.253 & 0.09128 \\
\hline 0.256 & 0.06251 & 0.256 & 0.09212 \\
\hline 0.263 & 0.06441 & 0.263 & 0.09492 \\
\hline 0.274 & 0.06707 & 0.274 & 0.09884 \\
\hline 1.542 & 0.37734 & 1.542 & 0.55608 \\
\hline 1.599 & 0.39121 & 1.599 & 0.57652 \\
\hline 1.643 & 0.40204 & 1.643 & 0.59248 \\
\hline 1.668 & 0.40204 & 1.668 & 0.59248 \\
\hline 1.732 & 0.50204 & 1.732 & 0.59248 \\
\hline 1.818 & 0.40204 & 1.818 & 0.59248 \\
\hline 8 & 0.40204 & 8 & 0.59248 \\
\hline 10.273 & 0.35226 & 10.273 & 0.51912 \\
\hline 12.545 & 0.31692 & 12.545 & 0.46704 \\
\hline 14.818 & 0.29013 & 14.818 & 0.42756 \\
\hline 17.091 & 0.26904 & 17.091 & 0.39648 \\
\hline 19.364 & $0.2519 A$ & 19.364 & 0.37128 \\
\hline 21.636 & 0.2375 & 21.636 & 0.35 \\
\hline 2.3 .909 & 0.22534 & 23.909 & 0.33208 \\
\hline 26.182 & 0.2147 & 26.182 & 0.3164 \\
\hline 28.455 & 0.20558 & 28.455 & 0.30296 \\
\hline 30.727 & 0.19722 & 30.727 & 0.29064 \\
\hline 33 & 0.19 & 33 & 0.28 \\
\hline 100 & 0.19 & 100 & 0.28 \\
\hline
\end{tabular}




\begin{tabular}{|c|c|c|c|c|c|c|c|c|c|c|c|}
\hline \multicolumn{12}{|c|}{ Second Floor Spectra.-5\% Damping } \\
\hline \multicolumn{2}{|c|}{ Horizonted $x$} & \multicolumn{2}{|c|}{ Horizontel $Y$} & \multicolumn{2}{|c|}{ Vertical Moda 5} & \multicolumn{2}{|c|}{ Vertical Node 38} & \multicolumn{2}{|c|}{ Vertical Node 70} & \multicolumn{2}{|c|}{ Vertical Node 178} \\
\hline (t) & (G) &  & $\left(C_{0}\right)$ & $(1+4)$ & (G) & (tha) & (Ca) & $(t+4)$ & (G) & 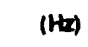 & (a) \\
\hline 0.2 & 0.00158 & 0.2 & 0.00179 & 0.2 & 0.00063 & 0.2 & 0.00062 & 0.2 & 0.00057 & 0.2 & 0.00082 \\
\hline 0.63 & 0.01187 & 0.53 & 0.01423 & 0.53 & 0.00413 & 0.53 & 0.00410 & 0.53 & 0.0041 & 0.63 & 0.00436 \\
\hline 0.68 & 0.00000 & 0.86 & 0.04305 & 0.86 & 0.01363 & 0.66 & 0.0128 & 0.80 & 0.01372 & 0.06 & 0.01416 \\
\hline 1.10 & 0.08157 & 1.19 & 0.1201 & 1.10 & 0.02522 & 1.10 & 0.02535 & 1.18 & $: 02877$ & 1.10 & 0.02627 \\
\hline 1.62 & 0.10017 & 1.62 & 0.10281 & 1.62 & 0.05140 & 1.62 & $0.040 \times 4$ & 1.62 & 0.0513 & 1.62 & 0.05133 \\
\hline 1.85 & 0.31824 & 1.85 & 0.43094 & 1.85 & 0.07451 & 1.85 & 0.0701 & 1.85 & 0.08217 & 1.85 & 0.08077 \\
\hline 2.18 & 0.45173 & 2.18 & 0.55273 & 2.18 & 0.12033 & 2.18 & 0.11208 & 2.18 & 0.12611 & 2.18 & 0.12401 \\
\hline 2.51 & 0.71868 & 2.51 & 0.89237 & 2.51 & 0.15797 & 2.51 & 0.14884 & 2.51 & 0.161 & 2.51 & 0.15065 \\
\hline 2.84 & 1.0536 & 2.84 & 1.78736 & 284 & 0.22520 & 2.84 & 0.21314 & 2.84 & 0.23194 & 2.84 & 0.2312 \\
\hline 3.17 & 1.81830 & 3.17 & 2.14084 & 3.17 & 0.27000 & 3.17 & 0.26517 & 3.17 & 0.28165 & 3.17 & 0.26821 \\
\hline 3.5 & 2.10973 & 3.5 & 1.67004 & 3.5 & 0.35654 & 3.5 & 0.30783 & 3.5 & 0.36840 & 3.5 & 0.37823 \\
\hline 3.8 .3 & 1.40732 & 3.83 & 1.38725 & 3.83 & 0.54508 & 3.83 & 0.48939 & 3.83 & 0.58843 & 3.83 & 0.58693 \\
\hline 4.16 & 1.3525 & 4.16 & 1.21043 & 4.16 & 0.79127 & 4.16 & 0.70127 & 4.16 & 0.77838 & 4.18 & 0.80454 \\
\hline 4.49 & 1.1868 & 4.49 & 1.00088 & 4.49 & 0.9774 & 4.40 & 0.85000 & 4.49 & 1.06851 & 4.40 & 1.06104 \\
\hline 4.82 & 0.96280 & 4.82 & 0.87917 & 4.82 & 1.47952 & 4.82 & 1.34805 & 4.82 & 1.60100 & 4.82 & 1.68475 \\
\hline 5.16 & 0.86718 & 5.16 & 0.81814 & 6.16 & 2.30203 & 5.16 & 2.000 & 5.15 & 2.35148 & 5.18 & 2.48107 \\
\hline 5.48 & 0.82601 & 5.48 & 0.70073 & 5.48 & 2.08749 & 6.48 & 2.168 & 5.48 & 1.80004 & 5.48 & c. .3467 \\
\hline 5.81 & 0.81711 & 5.81 & 0.73661 & 5.81 & 1.8745 & 5.81 & 2.03955 & 5.81 & 1.37727 & 5.81 & 1.6805 \\
\hline 6.14 & 0.67910 & 6.14 & 0.74003 & 8.14 & 1.65430 & 6.14 & 1.70221 & 8.14 & 1.10652 & 6.14 & 1.52662 \\
\hline 6.47 & 0.66795 & 6.47 & 0.72152 & 647 & 1.42900 & 6.47 & 1.45511 & 6.47 & 1.07801 & 6.47 & 1.38981 \\
\hline 6.8 & 0.58784 & 6.8 & 0.71535 & 6.8 & 1.16276 & 6.8 & 1.34308 & 6.8 & 1.07311 & 6.8 & 1.06393 \\
\hline 7.13 & 0.5954 & 7.13 & 0.68197 & 7.13 & 1.03322 & 7.13 & 1.15515 & 7.13 & 1.20130 & 7.13 & 0.88588 \\
\hline 7.46 & 0.61763 & 7.16 & 0.69855 & 7.46 & 0.90919 & 7.46 & 0.97028 & 7.46 & 1.12568 & 7.46 & 0.8277 \\
\hline 7.79 & 0.70245 & 7.70 & 0.79484 & 7.79 & 0.00874 & 7.70 & 0.03344 & 7.70 & 0.94941 & 7.70 & 0.74278 \\
\hline 8.12 & 0.7566 & 8.12 & 0.8636 & 8.12 & 0.80348 & 8.12 & 0.810 & 8.12 & 0.00344 & 8.12 & 0.7811 \\
\hline 8.45 & 0.75257 & 8.45 & 0.78128 & 8.45 & 0.78274 & $8.45^{\circ}$ & 0.78052 & 8.45 & 0.74183 & 8.46 & 0.76536 \\
\hline 8.78 & 0.7050 & 8.78 & 0.76618 & 8.78 & 0.73101 & 8.78 & 0.74005 & 8.78 & 0.71848 & 8.78 & 0.76824 \\
\hline 9.11 & 0.79236 & 8.11 & 0.76601 & 811 & 0.62256 & 9.11 & 0.68268 & 9.11 & 0.67735 & 9.11 & 0.69634 \\
\hline
\end{tabular}


TABLE 2. CONTINUED.

\begin{tabular}{|c|c|c|c|c|c|c|c|c|c|c|c|}
\hline \multicolumn{12}{|c|}{ Second Floor Spectra-.5\% Damping } \\
\hline \multicolumn{2}{|c|}{ Horizontal $X$} & \multicolumn{2}{|c|}{ Horizontal Y } & \multicolumn{2}{|c|}{ Vertical Node 5} & \multicolumn{2}{|c|}{ Vertical Hode 38} & \multicolumn{2}{|c|}{ Vertical Node 70} & \multicolumn{2}{|c|}{ Vertical Node 178} \\
\hline 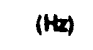 & (an) & $(H a)$ & (a) & $(1+2)$ & (a) & $($ (tat) & (a) & $(H+x)$ & (a) & $\left(H_{t}\right)$ & (a) \\
\hline 9.44 & 0.7975 & 0.44 & 0.70206 & 9.44 & 0.57121 & 9.44 & 0.63763 & 9.44 & 0.81011 & 9.44 & 0.66074 \\
\hline 9.77 & 0.80162 & 9.77 & 0.61906 & 9.77 & 0.57088 & 9.77 & 0.64606 & 9.77 & 0.6612 & 9.77 & 0.58437 \\
\hline 10.1 & 0.77218 & 10.1 & 0.60752 & 10.1 & 0.562 & 10.1 & 0.68448 & 10.1 & 0.65445 & 10.1 & 0.54719 \\
\hline 10.43 & 0.67690 & 10.43 & 0.62072 & 10.43 & 0.53217 & 10.43 & 0.64346 & 10.43 & 0.65844 & 10.43 & 0.55735 \\
\hline 10.78 & 0.57411 & 10.76 & 0.62098 & 10.78 & 0.6293 & 10.76 & 0.5869 & 10.76 & 0.65069 & 10.78 & 0.54811 \\
\hline 11.09 & 0.54873 & 11.00 & 0.58685 & 11.00 & 0.52919 & 11.00 & 0.58586 & 11.00 & 0.66266 & 11.08 & 0.53604 \\
\hline 11.42 & 0.55292 & 11.42 & 0.57317 & 11.42 & 0.52514 & 11.42 & 0.59105 & 11.42 & 0.66197 & 11.42 & 0.53535 \\
\hline 11.75 & $0.5 \mathrm{4m4}$ & 11.75 & 0.57417 & 11.75 & 0.51507 & 11.76 & 0.69087 & 11.75 & 0.85637 & 11.75 & 0.55263 \\
\hline 12.08 & 0.53756 & 12.08 & 0.55686 & 12.08 & 0.50306 & 12.08 & 0.57961 & 12.08 & 0.63103 & 12.08 & 0.56038 \\
\hline 12.41 & 0.56251 & 10.41 & 0.55686 & 12.41 & 0.50055 & 12.41 & 0.57974 & 12.41 & 0.62554 & 12.41 & 0.64875 \\
\hline 12.74 & 0.54874 & 12.74 & 0.50552 & 12.74 & 0.48308 & 12.74 & 0.57008 & 12.74 & 0.61113 & 12.74 & 0.62024 \\
\hline 13.07 & 0.53717 & 13.07 & 0.5611 & 13.07 & 0.459 & 13.07 & 0.54126 & 13.07 & 0.57568 & 13.07 & 0.48094 \\
\hline 13.4 & 0.53655 & 13.4 & 0.56647 & 13.4 & 0.45904 & 13.4 & 0.52157 & 13.4 & 0.54447 & 13.4 & 0.45129 \\
\hline 13.73 & 0.52024 & 13.73 & 0.57409 & 13.73 & 0.46481 & 13.73 & 0.53995 & 13.73 & 0.53429 & 13.73 & 0.4501 \\
\hline 14.06 & 0.51258 & 14.06 & 0.57335 & 14.06 & 0.4753 & 14.00 & 0.50124 & 14.00 & 0.53373 & 14.06 & 0.45446 \\
\hline 14.30 & 0.50784 & 14.39 & 0.55625 & 14.30 & 0.47047 & 14.39 & 0.55737 & 14.30 & 0.51822 & 14.30 & 0.44848 \\
\hline 14.72 & 0.48865 & 14.72 & 0.53362 & 14.72 & 0.45913 & 14.72 & 0.51762 & 14.72 & 0.48888 & 14.72 & 0.44279 \\
\hline 15.05 & 0.47083 & 15.05 & 0.51512 & 15.05 & 0.43983 & 15.05 & 0.52591 & 15.05 & 0.4615 & 15.05 & 0.45798 \\
\hline 15.38 & 0.46741 & 15.38 & 0.50987 & 15.38 & 0.43668 & 15.38 & 0.53185 & 15.38 & 0.42848 & 15.38 & 0.45233 \\
\hline 15.71 & 0.47818 & 15.71 & 0.5173 & 15.71 & 0.42839 & 15.71 & 0.51702 & 15.71 & 0.42867 & 15.71 & 0.43909 \\
\hline 16.04 & 0.48071 & 16.04 & 0.52083 & 18.04 & 0.42144 & 18.04 & 0.50374 & 16.04 & 0.43889 & 18.04 & 0.42699 \\
\hline 16.37 & 0.49524 & 18.37 & 0.5155 & 16.37 & 0.41297 & 18.37 & 0.48833 & 18.37 & 0.44478 & 18.37 & 0.4151 \\
\hline 16.7 & 0.48391 & 16.7 & 0.50168 & 16.7 & 0.40344 & 16.7 & 0.50253 & 18.7 & 0.44383 & 16.7 & 0.40624 \\
\hline 17.03 & 0.48563 & 17.03 & 0.40043 & 17.03 & 0.39839 & 17.03 & 0.49402 & 17.03 & 0.43108 & 17.03 & 0.40538 \\
\hline 17.36 & 0.47545 & 17.36 & 0.4787 & 17.36 & 0.39417 & 17.38 & 0.48092 & 17.36 & 0.42114 & 17.36 & 0.40805 \\
\hline 17.69 & 0.46898 & 17.69 & 0.46887 & 17.69 & 0.39191 & 17.69 & 0.46876 & 17.60 & 0.42331 & 17.60 & 0.40634 \\
\hline 18.02 & 0.46663 & 18.02 & 0.46358 & 18.02 & 0.39064 & 18.02 & 0.45706 & 18.02 & 0.42127 & 18.02 & 0.39836 \\
\hline 18.35 & 0.46318 & 18.35 & 0.45788 & 18.35 & 0.38805 & 18.35 & 0.44772 & 18.35 & 0.42816 & 18.35 & 0.3808 \\
\hline
\end{tabular}


TABLE 2. CONTINUED.

\begin{tabular}{|c|c|c|c|c|c|c|c|c|c|c|c|}
\hline \multicolumn{12}{|c|}{ Second Floor Spectra-.5\% Damping } \\
\hline \multicolumn{2}{|c|}{ Horizontal $X$} & \multicolumn{2}{|c|}{ Hortzontal Y } & \multicolumn{2}{|c|}{ Vortical Node 5} & \multicolumn{2}{|c|}{ Vertical Node 39} & \multicolumn{2}{|c|}{ Vortical Noda 70} & \multicolumn{2}{|c|}{ Vertical Node 178} \\
\hline (Hta) & (a) & $(\mathbf{H e r})$ & (Ge) & $(H A)$ & (G) & $(H)$ & (c) & $(t+x)$ & (ल) & $\left(\mathrm{H}_{2}\right)$ & (C) \\
\hline 18.68 & 0.45833 & 18.88 & 0.4489 & 18.68 & 0.37624 & 18.68 & 0.43821 & 18.68 & 0.43053 & 18.68 & 0.38829 \\
\hline 19.01 & 0.45701 & 19.01 & 0.43781 & 19.01 & 0.37294 & 19.01 & 0.43328 & $\$ 9.01$ & 0.43288 & 19.01 & 0.38673 \\
\hline 19.34 & 0.46148 & 19.34 & 0.43247 & 19.34 & 0.37075 & 19.34 & 0.42890 & 19.34 & 0.43167 & 19.34 & 0.38278 \\
\hline 19.67 & 0.46131 & 19.67 & 0.43698 & 19.67 & 0.37271 & 19.67 & 0.42544 & 19.67 & 0.42780 & 19.87 & 0.378 \\
\hline 20 & 0.4530 & 20 & 0.44753 & 20 & 0.37604 & 20 & 0.42316 & 20 & 0.43000 & $\mathbf{2 0}$ & 0.3749 \\
\hline 20.33 & 0.44488 & 20.33 & 0.45610 & 20.33 & 0.37749 & 20.33 & 0.42203 & 20.33 & 0.42782 & 20.33 & 0.37284 \\
\hline 20.66 & 0.4325 & 20.66 & 0.46265 & 20.66 & 0.37833 & 20.66 & 0.42112 & 20.68 & 0.42856 & 20.66 & 0.38976 \\
\hline 20.99 & 0.42358 & 20.90 & 0.46633 & 20.99 & 0.38066 & 20.99 & 0.41919 & 20.99 & 0.42845 & 20.99 & 0.36367 \\
\hline 21.32 & 0.41989 & 21.32 & 0.46548 & 21.32 & 0.38468 & 21.32 & 0.41658 & 21.32 & 0.42428 & 21.32 & 0.35644 \\
\hline 21.65 & 0.41947 & 21.65 & 0.46133 & 21.65 & 0.38765 & 21.60 & 0.41338 & 21.65 & 0.41798 & 21.65 & 0.35492 \\
\hline 21.98 & 0.41874 & 21.98 & 0.45544 & 21.98 & 0.39006 & 21.08 & 0.41035 & 21.98 & 0.41200 & 21.20 & 0.35557 \\
\hline 22.31 & 0.11751 & 22.31 & 0.44811 & 22.31 & 0.38882 & 22.31 & 0.41284 & 22.31 & 0.40777 & 22.31 & 0.35501 \\
\hline 22.64 & 0.41647 & 22.64 & 0.44362 & 22.64 & 0.38499 & 22.64 & 0.41346 & 22.64 & 0.40517 & 22.64 & 0.35385 \\
\hline 22.97 & 0.41468 & 22.97 & 0.43908 & 22.97 & 0.38019 & 22.97 & 0.41354 & 22.97 & 0.40414 & 22.97 & 0.35765 \\
\hline 23.3 & 0.4113 & 23.3 & 0.43582 & 23.3 & 0.37636 & 23.3 & 0.41405 & 23.3 & 0.40438 & 20.3 & 0.36174 \\
\hline 23.03 & 0.40731 & 23.63 & 0.43433 & 23.63 & 0.37115 & 23.63 & 0.41352 & 23.63 & a.406e? & 23.63 & 0.36472 \\
\hline 23.98 & 0.40433 & 23.96 & 0.43394 & 23.96 & 0.36482 & 23.08 & 0.4116 & 23.08 & 0.40615 & $22 a 88$ & 0.36632 \\
\hline 24.29 & 0.40271 & 24.29 & 0.43353 & 24.29 & 0.35859 & 24.29 & 0.40977 & 24.29 & 0.4065 & 24.29 & 0.36696 \\
\hline 24.62 & 0.40229 & 24.62 & 0.43297 & 24.62 & 0.35305 & 24.62 & 0.40781 & 24.62 & 0.40635 & 24.62 & 0.38732 \\
\hline 24.95 & 0.40234 & 24.95 & 0.43259 & 24.95 & 0.3482 & 24.95 & 0.40541 & 24.95 & 0.40000 & 24.96 & 0.36759 \\
\hline 25.28 & 0.40294 & 25.28 & 0.43257 & 25.28 & 0.34735 & 25.28 & 0.40285 & 25.28 & 0.40678 & 2528 & 0.36765 \\
\hline 25.61 & 0.40383 & 25.61 & 0.43281 & 25.61 & 0.34802 & 25.61 & 0.39051 & 25.31 & 0.400000 & 26.67 & 0.36725 \\
\hline 25.94 & 0.40498 & 25.94 & 0.433 & 25.94 & 0.34868 & 25.94 & 0.39592 & 25.24 & 0.4088 & 25.94 & 0.36687 \\
\hline 26.27 & 0.10645 & 26.27 & 0.43339 & 26.27 & 0.34916 & 28.27 & 0.3925 & 28.27 & 0.40533 & 28.27 & 0.3873 \\
\hline 26.6 & 0.40794 & 2.6 .6 & 0.43441 & 28.8 & 0.34868 & 28.6 & 0.38902 & 28.6 & 0.40448 & 28.8 & 0.36737 \\
\hline 26.93 & 0.40863 & 26.93 & 0.43582 & 26.93 & 0.3519 & 26.83 & 0.38558 & 28.23 & 0.40028 & 28.20 & 0.3664 \\
\hline 27.26 & 0.40838 & 27.28 & 0.43754 & 27.26 & 0.35587 & 27.28 & 0.38245 & 27.26 & 0.40000 & 27.28 & 0.36422 \\
\hline 27.58 & 0.40773 & 27.59 & 0.43956 & 27.59 & 0.35955 & 27.59 & 0.3814 & 27.50 & 0.30000 & 27.50 & 0.36113 \\
\hline
\end{tabular}


TABLE 2. CONTINUED.

\begin{tabular}{|c|c|c|c|c|c|c|c|c|c|c|c|}
\hline \multicolumn{12}{|c|}{ Second Floor Spectra-.5\% Dampling } \\
\hline \multicolumn{2}{|c|}{ Horizontal $x$} & \multicolumn{2}{|c|}{ Horizontal $\gamma$} & \multicolumn{2}{|c|}{ Vertical Node 5} & \multicolumn{2}{|c|}{ Vertlcal Nodw 39} & \multicolumn{2}{|c|}{ Vertical Node 70} & \multicolumn{2}{|c|}{ Vertical Hode i78 } \\
\hline$(H)$ & $\left(C_{0}\right)$ & $($ (H) & (C) & (Hta) & (G) & (He) & (Go) & $(t+2)$ & (Co) & $(H(x)$ & (G) \\
\hline 27.82 & 0.40764 & 27.22 & 0.44111 & 27.92 & 0.36265 & 27.92 & 0.38104 & 27.92 & 0.39733 & 27.82 & 0.35771 \\
\hline 28.25 & 0.40762 & 28.25 & 0.44159 & 28.25 & 0.36410 & 28.26 & 0.38078 & 28.25 & 0.39649 & 28.26 & 0.35446 \\
\hline 28.58 & 0.40784 & 28.58 & 0.44037 & 28.58 & 0.36443 & 28.58 & 0.300222 & 28.58 & 0.39681 & 28.58 & 0.36181 \\
\hline 28.81 & 0.40507 & 28.01 & 0.43731 & 28.91 & 0.38480 & 28.91 & 0.39046 & 28.91 & 0.3003 & 28.91 & 0.35022 \\
\hline 29.24 & 0.41119 & 29.24 & 0.43428 & 29.24 & 0.36446 & 20.24 & 0.38168 & 29.24 & 0.40043 & 29.24 & 0.34889 \\
\hline 29.57 & 0.41396 & 29.57 & 0.13042 & 28.57 & 0.36375 & $29.5 i$ & 0.38254 & 29.57 & $0.41 \cdot 24$ & 29.57 & 0.35046 \\
\hline 29.9 & 0.41536 & 29.9 & 0.4267 & 29.9 & 0.3629 & 29.9 & 0.38314 & 29.9 & 0.40375 & 29.9 & 0.35138 \\
\hline 30.23 & 0.41554 & 30.23 & 0.42528 & 30.23 & 0.36176 & 30.23 & 0.38356 & 30.23 & 0.4047 & 30.23 & 0.35230 \\
\hline 30.56 & 0.41427 & 30.56 & 0.428 & 30.68 & 0.36018 & 30.56 & 0.39375 & 30.56 & 0.40572 & 30.56 & 0.35356 \\
\hline 30.89 & 0.41232 & 30.80 & 0.42803 & 30.89 & 0.35821 & 30.89 & 0.38431 & 30.69 & 0.40694 & 30.69 & 0.355 \\
\hline 31.22 & 0.41042 & 31.22 & 0.43053 & 31.22 & 0.35821 & 31.22 & 0.38507 & 31.22 & 0.40807 & 31.22 & 0.35668 \\
\hline 31.55 & 0.4099 & 31.55 & 0.43284 & 31.55 & 0.35451 & 31.55 & 0.38517 & 31.55 & 0.40877 & 31.55 & 0.35805 \\
\hline 31.88 & 0.4096 & 31.88 & 0.4347 & 31.88 & 0.35326 & 31.88 & 0.38447 & 31.88 & 0.40881 & 31.88 & 0.155923 \\
\hline 32.21 & 0.40932 & 32.21 & 0.43821 & 32.21 & 0.35248 & 32.21 & 0.38288 & 32.21 & 0.40805 & 32.21 & 0.35994 \\
\hline 32.54 & 0.40804 & 32.54 & 0.43745 & 32.54 & 0.36213 & 32,54 & 0.38033 & 32.54 & 0.4085 & 32.54 & 0.36005 \\
\hline 32.87 & 0.40858 & 32.87 & 0.43834 & 32.87 & 0.35223 & 32.87 & 0.37891 & 32.87 & 0.40443 & 32.87 & 0.35959 \\
\hline
\end{tabular}


TABLE 2. CONTINUED.

\begin{tabular}{|c|c|c|c|c|c|c|c|c|c|c|c|}
\hline \multicolumn{12}{|c|}{ Roof Spactra--5\%, Damping } \\
\hline \multicolumn{2}{|c|}{ Horizontal X } & \multicolumn{2}{|c|}{ Horizontal Y } & \multicolumn{2}{|c|}{ Vertical Node 39} & \multicolumn{2}{|c|}{ Vertical Node 69} & \multicolumn{2}{|c|}{ Vertical Node 96} & \multicolumn{2}{|c|}{ Vertical Node 187} \\
\hline$(H(z)$ & (G) & $\left(\mathrm{H}_{2}\right)$ & (Gs) & $\mathrm{OHz}$ & (Gs) & $\mathrm{OH} 2)$ & (Gs) & $\mathrm{Hz}$ & (Gs) & $\mathrm{AHz}$ & (Gs) \\
\hline 0.2 & 0.00215 & 0.2 & 0.00248 & 0.2 & 0.00057 & 0.2 & 0.00081 & 0.2 & 0.00091 & 0.2 & 0.00081 \\
\hline 0.53 & 0.01617 & 0.53 & 0.01059 & 0.53 & 0.00212 & 0.53 & 0.00451 & 0.53 & 0.0047 & 0.53 & 0.00514 \\
\hline 0.86 & 0.05437 & 0.86 & 0.06014 & 0.86 & 0.00571 & 0.86 & 0.01213 & 0.86 & 0.01469 & 0.86 & 0.01598 \\
\hline 1.19 & 0.11016 & $i .19$ & 0.17338 & 1.19 & 0.01231 & 1.19 & 0.02822 & 1.19 & 0.02372 & 1.19 & 0.03196 \\
\hline 1.52 & 0.22753 & 1.52 & 0.26878 & 1.52 & 0.02369 & 1.52 & 0.04617 & 1.52 & 0.042 & 1.52 & 0.05381 \\
\hline 1.85 & 0.43968 & 1.85 & 0.59807 & 1.85 & 0.03918 & 1.85 & 0.07407 & 1.85 & 0.08736 & 1.85 & 0.08905 \\
\hline 2.18 & 0.63021 & 2.18 & 0.77745 & 2.18 & $0.04^{\prime} 388$ & 2.18 & 0.11699 & 2.18 & 0.12295 & 2.18 & 0.13491 \\
\hline 2.51 & 1.0002 & 2.51 & 1.24895 & 2.51 & 0.06608 & 2.51 & 0.15907 & 2.51 & 0.14628 & 2.51 & 0.18089 \\
\hline 2.84 & 1.46925 & 2.84 & 2.52171 & 2.84 & 0.08790 & 2.84 & 0.2196 & 2.84 & 0.23805 & 2.84 & 0.25973 \\
\hline 3.17 & 2.7002 & 3.17 & 3.0659 & 3.17 & 0.10803 & 3.17 & 0.2508 & 3.17 & 0.26277 & 3.17 & 0.29959 \\
\hline 3.5 & 3.0318 & 3.5 & 2.40703 & 3.5 & C. 1451 & 3.5 & 0.35218 & 3.5 & 0.36991 & 3.5 & 0.42165 \\
\hline 3.83 & 2.03098 & 3.83 & 2.00586 & 3.83 & 0.21864 & 3.83 & 0.52075 & 3.83 & 0.52696 & 3.83 & 0.64316 \\
\hline 4.16 & 1.97288 & 4.16 & 1.79521 & 4.16 & 0.29308 & 4.16 & 0.81108 & 4.16 & 0.7061 & 4.13 & 0.97861 \\
\hline 4.49 & 1.7875 & 4.49 & 1.6024 & 4.49 & 0.33932 & 4.49 & 1.142 & 4.49 & 0.98322 & 4.49 & 1.38095 \\
\hline 4.82 & 1.46405 & 4.82 & 1.32866 & 4.82 & 0.4683 & 4.82 & 1.68928 & 4.82 & 1.62067 & 4.82 & $2.0085 ?$ \\
\hline 5.15 & 1.29447 & 5.15 & 1.24991 & 5.15 & 0.52993 & 5.15 & 1.96115 & 5.15 & 2.34145 & 5.15 & 2.52961 \\
\hline 5.48 & 1.36797 & 5.48 & 1.27362 & 5.48 & 0.6004 & 5.48 & 1.65 & 5.48 & 1.99208 & 5.48 & 2.0029 \\
\hline 5.81 & 1.30722 & 5.81 & 1.30773 & 5.81 & 0.61407 & 5.81 & 1.69572 & 5.81 & 1.54765 & 5.81 & 1.68494 \\
\hline 0.14 & 1.21059 & 6.14 & 1.29259 & 0.14 & 0.50068 & 6.14 & 1.88583 & 6.14 & 1.30927 & 0.14 & 1.59674 \\
\hline 3.47 & 1.35916 & 6.47 & 1.29178 & 6.47 & 0.51343 & 6.47 & 1.8502 & 6.47 & 1.20611 & 3.47 & 1.40077 \\
\hline 6.8 & 1.32676 & 6.8 & 1.31201 & 0.8 & 0.73694 & 6.8 & 2.07781 & 6.8 & 1.23111 & 6.8 & 123332 \\
\hline 7.13 & 1.35763 & 7.13 & 1.20233 & 7.13 & 0.99531 & 7.13 & 2.09537 & 7.13 & 1.45221 & 7.13 & 1.29627 \\
\hline 7.46 & 1.38061 & 7.46 & 1.20201 & 7.46 & 1.22962 & 7.46 & 2.04495 & 7.46 & 1.61883 & 7.46 & 1.22789 \\
\hline
\end{tabular}


TABLE 2. CONTINUED.

\begin{tabular}{|c|c|c|c|c|c|c|c|c|c|c|c|}
\hline \multicolumn{12}{|c|}{ Roof Spectra-.5\% Damping } \\
\hline \multicolumn{2}{|c|}{ Horizontal $X$} & \multicolumn{2}{|c|}{ Horizonial Y } & \multicolumn{2}{|c|}{ Vertical Node 39} & \multicolumn{2}{|c|}{ Vertical Node 69} & \multicolumn{2}{|c|}{ Vertical Node 96} & \multicolumn{2}{|c|}{ Vertical Node 187} \\
\hline$(\mathrm{H} z)$ & (Gs) & $(\mathrm{Hz})$ & (Gs) & $(\mathrm{Hz})$ & (Gs) & $(\mathrm{Hz})$ & (Gs) & $(\mathrm{Hz})$ & (Gs) & $\left(\mathrm{H}_{2}\right)$ & (Gs) \\
\hline 7.79 & 1.30807 & 7.79 & 1.0308 & 7.79 & 1.46139 & 7.79 & 1.78718 & 7.79 & 1.75195 & 7.79 & 1.01335 \\
\hline 8.12 & 1.11803 & 8.12 & 0.89652 & 8.12 & 1.36844 & 8.12 & 1.39829 & 8.12 & 1.74166 & 8.12 & 0.8696 \\
\hline 8.45 & 0.86822 & 8.45 & 0.81699 & 8.45 & 1.16717 & 8.45 & 1.22744 & 8.45 & 1.40341 & 8.45 & 0.78507 \\
\hline 8.78 & 0.76941 & 8.78 & 0.77392 & 8.78 & 0.98783 & 8.78 & 1.09193 & 8.78 & 1.20974 & 8.78 & 0.76534 \\
\hline 0.11 & 0.72394 & $9: 11$ & 0.755995 & 9.11 & 0.8567 & 9.11 & 0.95726 & 9.11 & 1.11655 & 9.11 & 0.76035 \\
\hline 9.44 & 0.70881 & 9.44 & 0.71587 & 9.44 & 0.80302 & 9.44 & 0.89538 & 9.44 & 1.01825 & 9.44 & 0.73994 \\
\hline 9.77 & 0.70539 & 9.77 & 0.70916 & 9.77 & 0.75099 & 9.77 & 0.82956 & 9.77 & 0.98516 & 9.77 & 0.78081 \\
\hline 10.1 & 0.73089 & 10.1 & 0.73575 & 10.1 & 0.80747 & 10.1 & 0.7716 & 10.1 & 0.87242 & 10.1 & 0.72029 \\
\hline 10.43 & 0.75077 & 10.43 & 0.73806 & 10.43 & 0.7731 & 10.43 & $0.7447 ?$ & 10.43 & 0.7816 & 10.43 & 0.65506 \\
\hline 10.76 & 0.72127 & 10.76 & 0.71627 & 10.76 & 0.71293 & 10.76 & 0.72924 & 10.76 & 0.76261 & 116 & 0.63059 \\
\hline 11.09 & 0.69047 & 11.09 & 0.70073 & 11.09 & 0.67894 & 11.09 & 0.68724 & 11.09 & 0.77699 & 11.09 & 0.62059 \\
\hline 11.42 & 0.70481 & 11.42 & 0.70311 & 11,42 & 0.64463 & 11.42 & 0.65264 & 11.42 & 0.74895 & 11.42 & 0.59823 \\
\hline 11.75 & 0.70088 & 11.75 & 0.70347 & 11.75 & 0.60773 & 11.75 & 0.65294 & 11.75 & 0.69933 & 11.75 & 0.58521 \\
\hline 12.08 & 0.68961 & 12.08 & 0.69238 & 12.08 & 0.5694 & 12.08 & 0.65642 & 12.08 & 0.64473 & 12.08 & 0.58697 \\
\hline 12.41 & 0.0225 & 12.41 & 0.6916 & 12.41 & 0.55953 & 12,41 & 0.64016 & 12.41 & 0.61206 & 12.41 & 0.5808 \\
\hline 12.74 & 0.62976 & 12.74 & 0.68235 & 12.74 & 0.55948 & 12.74 & 0.63334 & 12.74 & 0.60446 & 12.74 & 0.57624 \\
\hline 13.07 & 0.62903 & 13.07 & 0.67392 & 13.07 & 0.52778 & 13.07 & 0.63778 & 13.07 & 0.64283 & 13.07 & 0.57943 \\
\hline 13.4 & 0.63524 & 13.4 & 0.6769 & 13.4 & 0.49396 & 13.4 & 0.63684 & 13.4 & 0.64826 & 13.4 & 0.58046 \\
\hline 13.73 & 0.62704 & 13.73 & 0.66696 & 13.73 & 0.47718 & 13.73 & 0.62541 & 13.73 & 0.61477 & 13.73 & 0.57433 \\
\hline 14.06 & 0.62258 & 14.06 & 0.65853 & 14.06 & 0.47692 & 14.06 & 0.59842 & 14.06 & 0.5825 & 14.06 & 0.55943 \\
\hline 14.39 & 0.62162 & 14.39 & 0.66157 & 14.39 & 0.47085 & 14.39 & 0.5660 & 14.39 & 0.58544 & 14.39 & 0.53558 \\
\hline 14.72 & $0.6 C 854$ & 14.72 & 0.66102 & 14.72 & 0.45356 & 14.72 & 0.55237 & 14.72 & 0.58447 & 14.72 & 0.50585 \\
\hline 15.05 & 0.59271 & 15.05 & 0.66019 & 15.05 & 0.42201 & 15.05 & 0.55181 & 15.05 & 0.58836 & 15.05 & 0.48966 \\
\hline 15.38 & 0.58698 & 15.38 & $0.6 x 474$ & 15.38 & 0.39127 & 15.38 & 0.55258 & 15.38 & 0.58247 & 15.38 & 0.4812 \\
\hline 15.71 & 0.59575 & 15.71 & 0.66751 & 15.71 & 0.37643 & 15.71 & 0.55134 & 15.71 & 0.59523 & 15.71 & 0.49271 \\
\hline 16.04 & 0.60943 & 16.04 & 0.66684 & 16.04 & 0.37603 & 16.04 & 0.54384 & 16.04 & 0.592 & 16.04 & 0.50547 \\
\hline 16.37 & 0.61726 & 16.37 & 0.66365 & 16.37 & 0.37059 & 16.37 & 0.53037 & 16.37 & 0.57362 & 16.37 & 0.50191 \\
\hline
\end{tabular}


TABLE 2. CONTINUED.

\begin{tabular}{|c|c|c|c|c|c|c|c|c|c|c|c|}
\hline \multicolumn{12}{|c|}{ Roof Spectra--5\% Damping } \\
\hline \multicolumn{2}{|c|}{ Horizontal X } & \multicolumn{2}{|c|}{ Horizontal Y } & \multicolumn{2}{|c|}{ Vertical Node 39} & \multicolumn{2}{|c|}{ Vertical Nods 69} & \multicolumn{2}{|c|}{ Vertical Node 96} & \multicolumn{2}{|c|}{ Vertical Node 187} \\
\hline$(\mathrm{H}(2)$ & (G) & $(\mathrm{O}+2)$ & (Gs) & (Hz) & (Gs) & $\mathrm{OH}_{22}$ & (Gs) & 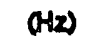 & (Go) & (H) & (Gs) \\
\hline 16.7 & 0.61845 & 16.7 & 0.65352 & 16.7 & 0.37881 & 16.7 & 0.52078 & 16.7 & 0.55966 & 16.7 & 0.49638 \\
\hline 17.03 & 0.01933 & 17.03 & 0.63975 & 17.03 & 0.37345 & 17.03 & 0.51657 & 17.03 & 0.54837 & 17.03 & 0.49882 \\
\hline 17.36 & 0.62657 & 17.36 & 0.62518 & 17.36 & 0.38217 & 17.36 & 0.51057 & 17.36 & 0.53691 & 17.36 & 0.50617 \\
\hline 17.69 & 0.62958 & 17.69 & 0.61279 & 17.69 & 0.35294 & 17.69 & 0.5117 & 17.69 & 0.51833 & 17.69 & 0.51205 \\
\hline 18.02 & 0.6285 & 18.02 & 0.59844 & 18.02 & 0.34829 & 18.02 & 0.51009 & 18.02 & 0.49883 & 18.02 & 0.51557 \\
\hline 18.35 & 0.62382 & 18,35 & 0.58465 & 18.35 & 0.34555 & 18.35 & 0.50613 & 18.35 & 0.48368 & 18.35 & 0.51547 \\
\hline 18.68 & 0.61629 & 18.68 & 0.57892 & 18.68 & 0.34403 & 18.68 & 0.49962 & 18.68 & 0.47321 & 18.68 & 0.51348 \\
\hline 19.01 & 0.60671 & 19.01 & 0.57415 & 19.01 & 0.34266 & 19.01 & 0.49156 & 19.01 & 0.46655 & 19.01 & 0.50922 \\
\hline 19.34 & 0.5998 & 19.34 & 0.57357 & 19.34 & 0.33893 & 19.34 & 0.48295 & 19.34 & 0.46216 & 19.34 & 0.50282 \\
\hline 19.67 & 0.5972 & 19.67 & 0.58199 & 19.67 & 0.33271 & 19.67 & 0.48711 & 19.67 & 0.4589 & 19.67 & 0.49695 \\
\hline 20 & 0.59421 & 20 & 0.58714 & 20 & 0.32647 & 20 & 0.49497 & 20 & 0.45669 & 20 & 0.49413 \\
\hline 20.33 & 0.58774 & 20.33 & 0.58785 & 20.33 & 0.32055 & 20.33 & 0.50024 & 20.33 & 0.4547 & 20.33 & 0.49203 \\
\hline 20.66 & 0.58409 & 20.66 & 0.58636 & 20.66 & 0.3171 & 20.66 & 0.50092 & 20.66 & 0.45187 & 20.66 & 0.48696 \\
\hline 20.99 & $0.578 y 2$ & 20.99 & $0.5828 \mathrm{~A}$ & 20.99 & 0.31866 & 20.99 & 0.40 .75 & 20.99 & 0.44897 & 20.99 & 0.47845 \\
\hline 21.32 & 0.57383 & 21.32 & 0.57821 & 21.32 & 0.32209 & 21.32 & 0.494 & 21.32 & 0.44792 & 21.32 & $0.46 \%$ \\
\hline 21.65 & 0.56864 & 21.65 & 0.57387 & 21.65 & 0.3261 & 21.65 & 0.49034 & 21.65 & 0.44749 & 21.65 & 0.46369 \\
\hline 2998 & 0.56329 & 21.98 & 0.57175 & 21.98 & 0.32696 & 21.98 & 0.48652 & 21.98 & 0.44676 & 21.98 & 0.46128 \\
\hline 22.31 & 0.55965 & 22.31 & 0.57167 & 22.31 & 0.32445 & 22.31 & 0.48172 & 22.31 & 0.44567 & 22.31 & 0.4627 \\
\hline 22.64 & 0.55868 & 22.64 & 0.57205 & 22.64 & 0.32051 & 22.64 & 0.47655 & 22.64 & 0.44487 & 22.64 & 0.46548 \\
\hline 22.97 & 0.557 & 22.97 & 0.57222 & 22.97 & 0.31725 & 22.97 & 0.4734 & 22.97 & 0.44532 & 22.97 & 0.46894 \\
\hline 23.3 & 0.5538 & 23.3 & 0.57215 & 23.3 & 0.31494 & 23.3 & 0.47604 & 23.3 & 0.4473 & 23.3 & 0.47195 \\
\hline 23.63 & 0.54996 & 23.63 & 0.57163 & 23.63 & 0.31229 & 23.63 & 0.48087 & 23.63 & 0.45011 & 23.63 & 0.47367 \\
\hline 23.96 & 0.54708 & 23.96 & 0.57042 & 23.96 & 0.30906 & 23.96 & 0.48539 & 23.96 & 0.45262 & 23.96 & 0.47422 \\
\hline 24.29 & 0.54539 & 24.29 & 0.56883 & 24.29 & 0.30638 & 24.20 & 0.48838 & 24.29 & 0.45383 & 24.29 & 0.475 \\
\hline 24.62 & 0.54423 & 24.62 & 0.56749 & 24.62 & 0.30383 & 24.62 & 0.48952 & 24.62 & 0.45348 & 24.62 & 0.47532 \\
\hline 24.95 & 0.54353 & 24.95 & 0.56746 & 24.95 & 0.30194 & 24.95 & 0.49096 & 24.95 & 0.45268 & 24.95 & 0.47541 \\
\hline 25.28 & 0.54348 & 25.28 & 0.56742 & 25.28 & 0.30084 & 25.28 & 0.4905 & 25.28 & 0.45133 & 25.28 & 0.4752 \\
\hline
\end{tabular}


TABLE 2. CONTINUED.

\begin{tabular}{|c|c|c|c|c|c|c|c|c|c|c|c|}
\hline \multicolumn{12}{|c|}{ Roof Spectra--5\% Damplng } \\
\hline \multicolumn{2}{|c|}{ Horizontal $\mathrm{X}$} & \multicolumn{2}{|c|}{ Horizontal Y } & \multicolumn{2}{|c|}{ Vertical Node 39} & \multicolumn{2}{|c|}{ Vertical Node 69} & \multicolumn{2}{|c|}{ Vertical Node 96} & \multicolumn{2}{|c|}{ Vertical Node 187} \\
\hline$(\mathrm{Hz})$ & (Gs) & $(\mathrm{Hz})$ & (Gs) & $(\mathrm{Hz})$ & (Gs) & $(\mathrm{H} 2)$ & (Gs) & $(\mathrm{Hz})$ & (Gs) & $(\mathrm{Hz})$ & (Gs) \\
\hline 25.61 & 0.54389 & 25.61 & 0.56787 & 25.61 & 0.30027 & 25.61 & 0.48824 & 25.61 & 0.44883 & 25.61 & 0.47472 \\
\hline 25.94 & 0.54465 & 25.94 & 0.56866 & 25.94 & 0.29976 & 25.94 & 0.48453 & 25.94 & 0.44554 & 25.94 & 0.47404 \\
\hline 26.27 & 0.54598 & 26.27 & 0.56912 & 26.27 & 0.29873 & 26.27 & 0.47991 & 26.27 & 0.44201 & 26.27 & 0.47288 \\
\hline 26.6 & 0.54775 & 26.6 & 0.56907 & 26.6 & 0.29698 & 26.6 & 0.47527 & 26.6 & 0.43901 & 26.6 & 0.47087 \\
\hline 26.93 & 0.54919 & 26.93 & 0.56871 & 26.93 & 0.29499 & 26.93 & 0.47188 & 26.93 & 0.43707 & 26.93 & 0.46792 \\
\hline 27.26 & 0.55053 & 27.26 & 0.56829 & 27.26 & 0.2932 & 27.26 & 0.47062 & 27.26 & 0.43624 & 27.26 & 0.46434 \\
\hline 27.59 & 0.55288 & 27.59 & 0.56798 & 27.59 & 0.29134 & 27.59 & 0.47118 & 27.59 & 0.43614 & 27.59 & 0.46073 \\
\hline 27.92 & 0.55495 & 27.92 & 0.56803 & 27.92 & 0.28872 & 27.92 & 0.47258 & 27.92 & 0.43627 & 27.92 & 0.45758 \\
\hline 28.25 & 0.55747 & 28.25 & 0.56871 & 28.25 & 0.28516 & 28.25 & 0.47404 & 28.25 & 0.43639 & 28.25 & 0.45529 \\
\hline 28.58 & 0.55952 & 28.58 & 0.56989 & 28.58 & 0.28123 & 28.58 & 0.47532 & 28.58 & 0.43654 & 28.58 & 0.45428 \\
\hline 28.91 & 0.56097 & 28.91 & 0.57098 & 28.91 & 0.27795 & 28.91 & 0.47632 & 28.91 & 0.4369 & 28.91 & 0.4548 \\
\hline 29.24 & 0.56173 & 29.24 & 0.57144 & 29.24 & 0.27598 & 29.24 & 0.47668 & 29.24 & 0.43754 & 29.24 & 0.4565 \\
\hline 29.57 & 0.56185 & 29.57 & 0.57103 & 29.57 & 0.27521 & 29.57 & 0.47586 & 29.57 & 0.43832 & 29.57 & 0.45857 \\
\hline 29.9 & 0.56153 & 29.9 & 0.57041 & 29.9 & 0.275 & 29.9 & 0.47375 & 29.9 & 0.43913 & 29.9 & 0.46035 \\
\hline 30.23 & 0.5627 & 30.23 & 0.56888 & 30.23 & 0.2747 & 30.23 & 0.47079 & 30.23 & 0.44005 & 30.23 & 0.46176 \\
\hline 30.56 & 0.56378 & 30.56 & 0.560688 & 30.56 & 0.27463 & 30.56 & 0.46706 & 30.56 & 0.44127 & 30.56 & 0.46307 \\
\hline 30.89 & 0.56464 & 30.89 & 0.56603 & 30.89 & 0.27446 & 30.89 & 0.46505 & 30.89 & 0.44292 & 30.89 & 0.46433 \\
\hline 31.22 & 0.56503 & 31.22 & 0.56707 & 31.22 & 0.27398 & 31,22 & 0.46349 & 31.22 & 0.4451 & 31.22 & $0.46 c 34$ \\
\hline 31.55 & 0.56453 & 31.55 & 0.56953 & 31.55 & 0.27346 & 31.55 & 0.46312 & 31.55 & 0.44783 & 31.55 & 0.46583 \\
\hline 31.88 & 0.56279 & 31.88 & 0.57287 & 31.88 & 0.27314 & 31.88 & 0.46381 & 31.88 & 0.45094 & 31.88 & 0.46568 \\
\hline 32.21 & 0.56029 & 32.21 & 0.57639 & 32.21 & 0.27314 & 32.21 & 0.46528 & 32.21 & 0.45403 & 32.21 & 0.46482 \\
\hline 32.54 & 0.55867 & 32.54 & 0.57955 & 32.54 & 0.27339 & 32.54 & 0.46719 & 32.54 & 0.45653 & 32.54 & 0.46333 \\
\hline 32.87 & 0.55582 & 32.87 & 0.58199 & 32.87 & 0.27366 & 32.87 & 0.46922 & 32.87 & 0.45795 & 32.87 & 0.46146 \\
\hline
\end{tabular}


frequency ranges for each component (from Reference 18), acceleratlon distributlons were developed from the Table 2 data to represent an estimated mean acceleration at the required component locations.

The approprlate fragillty distributlon parameters were determined for each component based on Reference-18 components with similar structural propertles. Table 3 summarizes the results of the component mappling, Inclualing distribution parameters and the bullding structural node from Reference 47 that were used in determining component fragllity. The fragllity curves generated from these distributions are provided in Appendlx $A$.

By locating the acceleration value on the approprlate fragllity curve, the probability of fallure could be estimated. Thls probabillty, however, represented the fallure mode from Reference 18, which was usually anchor bolts or support fallures. To expan!! this estimate to include fallure probability that could represent a potential release, a cc nservative "breacin" factor of 0.1 was applied to all components where the fallure mode !nvolved supports or anchoring. The final fragllty determination for each component is included in the following area dlscussions and presented in Table 4.

\subsubsection{Area 1 Components}

The function of this area is waste feed and incineration. Area 1 consists of Rooms 109 and 120. The feed enclosure, located In Room 109, contains the equipment that performs the waste feed function. The kiln and secondary combustion chamber (SCC) located in Room 120 incinerate the waste and ensure complete comibustion of volatlle by-products of the incineration process, respectivel $\%$.

The feed enclosure consists of the feed conveyor and auger mechanism as shown in Figure 3. The feed conveyor recelves waste from the shredder dlscharge and transfers It vla the auger into the kiln. It is mounted to the second floor, a first mezzanine platform, and the wall adjacent to the klln. The fragillty for the feed conveyor is illustrated by the curve in Figure A-I (Appendlx A). As indicated in Table 4, fallure probabillty for the feed conveyor was estimated to be 0.00353 .

The incineration process is accomplished by the kiln and SCC, which are lllustrated in Figure 4. The klln burns all the combustibles and the SCC ensures that all volatile by-products are gasifled. The klln sits on a fiberglass support structure to permit some free movement. Additional support is provided by celling mounts. The SCC was assumed not to fall because of the sturdiness of structure and mountings (see 
TABLE 3. PREPP COMPONENT FRAGILITY SUMMARY

\begin{tabular}{|c|c|c|c|c|c|}
\hline \multirow[t]{2}{*}{ COMPONENT } & \multirow[t]{2}{*}{$\begin{array}{l}\text { DESCRIPTION } \\
\text { (Hrom Relorence 18) }\end{array}$} & \multirow[t]{2}{*}{ FAILURE MODE } & \multicolumn{2}{|c|}{$\begin{array}{l}\text { DISTRIBUTION } \\
\text { PARAMETERS }\end{array}$} & \multirow[t]{2}{*}{$\begin{array}{c}\text { NODE } \\
\text { (from Toble 2) }\end{array}$} \\
\hline & & & MEDIAN & BETA & \\
\hline FEED CONVEYOR & $\begin{array}{l}\text { LARGE HORIZONTAL VESSEL--lncludes large } \\
\text { storoge tanks and heat exchangers. } \\
\text { Charactertzed by large volume, relatively low } \\
\text { pressure, thin wall cyllindrical tanks mounted } \\
\text { with the ryllinder axis in the horkontal position. } \\
12 \% 0 \mathrm{~h} \text { : with } 5 \% \text { dampling. }\end{array}$ & FAILURE OF ANCHOR BOLTS & 3.91 & 0.61 & $70 / 178$ \\
\hline KILN & $\begin{array}{l}\text { LARGE HORIZONTAL VESSEl--Includes large } \\
\text { storage tanks and heat exchangers. } \\
\text { Characterized by large volume, relatively low } \\
\text { pressure, thin wall cylindrkcal tanks mounted } \\
\text { with the cyllnder cxis in the hortzontal position. } \\
12-20 \mathrm{hz} \text { with } 5 \% \text { dampling. }\end{array}$ & FAILURE OF ANCHOR BOLIS & 3.91 & 0.61 & $70 / 178$ \\
\hline $\begin{array}{l}\text { EMERGENCY } \\
\text { DRAIN TANK }\end{array}$ & $\begin{array}{l}\text { LARGE HORIZONTAL VESSEL--Includes large } \\
\text { storage tanks and heat exchangers, } \\
\text { Characterized by large volume, relatively low } \\
\text { pressure, thin wall cylindrlcal tanks mounted } \\
\text { with the cyllinder coxls in the hortzontal position. } \\
12-20 \mathrm{hz} \text { wilth it dampling. }\end{array}$ & FAILURE OF ANCHOR BOLTS & & & Ist Floor \\
\hline GROUT MIXER & $\begin{array}{l}\text { LARGE HORIZONTAL. VESSEL-Includes large } \\
\text { storage tanks and heat exchangers. } \\
\text { Characterized by large volume, relatively low } \\
\text { pressure, thin wall cylindrlcal tanks mounted } \\
\text { with the cyllinder axis in the horizuntal position. } \\
12-20 \mathrm{hz} \text { with } 5 \% \text { damping. }\end{array}$ & FAILURE OF ANCHOR BOLTS & & & 39 \\
\hline $\begin{array}{l}\text { FINES } \\
\text { HOPPERS/BLENDER } \\
\text { TANKS }\end{array}$ & $\begin{array}{l}\text { LARGE VERTICAL VESSEL WITH FORMED } \\
\text { HEAD--Includes accumulator and volume } \\
\text { control tanks. Typically low pressure with thin } \\
\text { wail construction supported by skitts. May have } \\
\text { non-integrally reinforced nozdes or } \\
\text { non-reinforced fabricated nozates. Fluid } \\
\text { stoshing and fluld-structure interaction are } \\
\text { critical with respect to dynamic response. } \\
4-10 \mathrm{hz} \text {. }\end{array}$ & $\begin{array}{l}\text { RUPTURE OF ANCHOR } \\
\text { BOLTS; BREAKING OF } \\
\text { SUPPORTS }\end{array}$ & 1.46 & 0.40 & 39 \\
\hline $\begin{array}{l}\text { ENTRAINMENT } \\
\text { ELIMINATOR }\end{array}$ & $\begin{array}{l}\text { LARGE VERTICAL VESSEL WITH FORMED } \\
\text { HEAD--ncludes accumulator and volume } \\
\text { control tanks. Typically low pressure with thin } \\
\text { wall construction supported by skirts. May have } \\
\text { non-integrally reinforced nocdes or } \\
\text { non-reinforced fabricated nozles. Fluid } \\
\text { sloshing and fluid-structure interactlon are } \\
\text { critical with respect to dynamic response. } \\
4-10 \mathrm{hz} \text {. }\end{array}$ & $\begin{array}{l}\text { RUPTURE OF ANCHOR } \\
\text { BOLTS: BREAKING OF } \\
\text { SUPPORTS }\end{array}$ & & & 39 \\
\hline VENTURI SCRUBBER & $\begin{array}{l}\text { LARGE VERTICAL VESSEL WTH FORMED } \\
\text { HEAD--Includes accumulator and volume } \\
\text { control tanks. Typlcally low pressure with thin } \\
\text { wall construction supported by skitrs. May have } \\
\text { non-integrally reinforced nozzles or } \\
\text { non-relnforced fabricated nozzes. Fluid } \\
\text { sloshing and fluld-structure interaction are } \\
\text { critlcal with respect to dynamic response. } \\
4-10 \mathrm{hz} \text {. }\end{array}$ & $\begin{array}{l}\text { RUPTURE OF ANCHOR } \\
\text { BOLTS; BREAKING OF } \\
\text { SUPPORTS }\end{array}$ & & & 39 \\
\hline
\end{tabular}


TABLE 3. CONCLUDED.

\begin{tabular}{|c|c|c|c|c|c|}
\hline \multirow[t]{2}{*}{ COMPONENT } & \multirow[t]{2}{*}{$\begin{array}{l}\text { DESCRIPTION } \\
\text { (Irom Reterence 18) }\end{array}$} & \multirow[t]{2}{*}{ FAILURE MODE } & \multicolumn{2}{|c|}{$\begin{array}{l}\text { DISTRIBUTION } \\
\text { PARAMETERS }\end{array}$} & \multirow[t]{2}{*}{$\begin{array}{c}\text { NODE } \\
\text { (trom Table 2) }\end{array}$} \\
\hline & & & MEDIAN & BETA & \\
\hline MIST ELIMINATOR & $\begin{array}{l}\text { LARGE VERTICAL VESSEL WTH FORMED } \\
\text { HEAD-Includes accumulator and volume } \\
\text { control tanks. Typlcally low pressure with thin } \\
\text { wall construction supported by skitts. May have } \\
\text { non-integrally reinforced nozzles or } \\
\text { non-reinforced fabicated nozdes. Fluld } \\
\text { sloshing and fluid-structure interaction are } \\
\text { critlcal with respect to dynamic response. } \\
4-10 \mathrm{hz} \text {. }\end{array}$ & $\begin{array}{l}\text { RUPTURE OF ANCHOR } \\
\text { BOLTS: BREAKING OF } \\
\text { SUPPORTS }\end{array}$ & & & 39 \\
\hline SLUDGE TANK & $\begin{array}{l}\text { LARGE VERTICAL VESSEL WTH FORMED } \\
\text { HI D-includes accumulator and volume } \\
\text { control tanks. TYplcally low pressure with thin } \\
\text { wall construction supported by skirts. May have } \\
\text { nun-integrally reiriforced nozzles or } \\
\text { non-reinforced fabricated nozzles. Fluld } \\
\text { sloshing and fluid-structure interaction are } \\
\text { critical with respect to dynamic response. } \\
\text { 4-10 hz. }\end{array}$ & $\begin{array}{l}\text { RUPTURE OF ANCHOR } \\
\text { BOLTS: BREAKING OF } \\
\text { SUPPCIRTS }\end{array}$ & & & 38 \\
\hline $\begin{array}{l}\text { SURGE RECYCLE } \\
\text { TANK }\end{array}$ & $\begin{array}{l}\text { LARGE VERTICAL VESSEL WITH FORMED } \\
\text { HEAD-Inciudes accumulator and volume } \\
\text { control tanks. Typlcally low pressure wilth thin } \\
\text { wall construction supported by skirts. May have } \\
\text { non-integrally reinforced nozzles or } \\
\text { non-reinforced fabricated nozdes. Fiuld } \\
\text { sloshing and fluid-structure interactlon are } \\
\text { critkal with respect to dynamic response. } \\
4-10 \mathrm{hz} \text {. }\end{array}$ & $\begin{array}{l}\text { RUPTURE OF ANCHOR } \\
\text { BOLTS: BREAKING OF } \\
\text { SUPPORTS }\end{array}$ & & & ist Floor \\
\hline $\begin{array}{l}\text { SURGE RECYCLE } \\
\text { DRAIIN TANK }\end{array}$ & 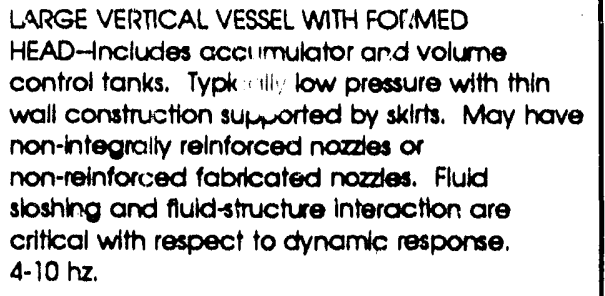 & $\begin{array}{l}\text { RUPTURE OF ANCHOR } \\
\text { BOLIS; BREAKING OF } \\
\text { SUPPORTS }\end{array}$ & & & 38 \\
\hline QUENCHER & $\begin{array}{l}\text { LARGE VERTICAL VESSEL--Large storage tanks } \\
\text { typlcally anchored to the foundation. Fluld } \\
\text { stoshing effects are critical with respect to } \\
\text { dynamle response. } 4-10 \mathrm{hz} \text {. }\end{array}$ & $\begin{array}{l}\text { FRACTURE OF ANCHOR } \\
\text { BOLTS }\end{array}$ & 2.01 & 0.38 & $38 / 187$ \\
\hline $\begin{array}{l}\text { DISCHARGE } \\
\text { CONVEYOR }\end{array}$ & $\begin{array}{l}\text { SMALL-MEDIUM VESSEL-Cylinditcal or spherical } \\
\text { In shape mounted hortzontally or vertlcally. } \\
\text { Supports are typically legs or saddles welded } \\
\text { directly to the pressure boundary and bolted to } \\
\text { the floor. } 15-30 \mathrm{hz} \text { with } 5 \% \text { damping. }\end{array}$ & $\begin{array}{l}\text { RUPTURE OF ANCHOR } \\
\text { BOLTS: SUPPORT FAILURE }\end{array}$ & 1.84 & 0.51 & $38 / 187$ \\
\hline GROUTED DRUMS & $\begin{array}{l}\text { SMALL-MEDIUM VESSEL-Cyllindical or spherical } \\
\text { in shape mounted horizontally or vertically, } \\
\text { Supports are typically legs or saddles welded } \\
\text { directly to the pressure boundary and bolted to } \\
\text { the floor. } 15-30 \mathrm{hz} \text { with } 5 \% \text { damping. }\end{array}$ & $\begin{array}{l}\text { RUPTURE OF ANCHOR } \\
\text { BOLTS; SUPPORT FAILURE }\end{array}$ & & & 178 \\
\hline $\begin{array}{l}\text { DRUMS BEING } \\
\text { FILED }\end{array}$ & $\begin{array}{l}\text { SMALL-MEDIUM VESSEL-Cylindical or spherical } \\
\text { in shape mounted horizontally or vertically. } \\
\text { Supports are typically legs or saddles welded } \\
\text { dlrectly to the pressure boundary and bolted to } \\
\text { the floor. } 15-30 \mathrm{hz} \text { with } 5 \% \text { damping. }\end{array}$ & $\begin{array}{l}\text { RUPTUR: OF ANCHOR } \\
\text { BOLTS; SUPPORT FAILURE }\end{array}$ & & & Ist Floor \\
\hline
\end{tabular}


TABLE 4. PREPP COMPONENT FRAGILITY VALUES

\begin{tabular}{|c|c|c|c|}
\hline & PREPP Component & Fragllity & Total Fragillty \\
\hline $\mathrm{FC}$. & - Feed Conveyor & 0.0353 & 0.00353 \\
\hline $\mathrm{KL}=$ & $-\quad K \| I n$ & 0.0024 & 0.00024 \\
\hline $\mathrm{B} 1$ & - HVAC System & 0.0900 & 0.09000 \\
\hline D2 & - Grouted drums & 0.1700 & 0.01700 \\
\hline $\mathrm{T} 1$ & - Surge Recycle Tank (SRT) & 0.1295 & 0.01295 \\
\hline si - & - Sludge tank (reclr. w/SRT) & 0.6110 & 0.06110 \\
\hline T2 & - Surge Recycle Drain Tank & 0.6110 & 0.06110 \\
\hline ET - & - Emergency Drain Tanik & 0.0024 & 0.00024 \\
\hline S2 - & - Sludge tank (grouting) & 0.6110 & 0.06110 \\
\hline s3 & - Sludge tank (sparging) & 0.6110 & 0.06110 \\
\hline $\mathrm{P} 2$ & - Sludge pump for \$2 & 0.0087 & 0.00087 \\
\hline P3 & - Sludge pump for $\$ 3$ & 0.0087 & 0.00087 \\
\hline$M X$. & - Grout mixer & 0.0071 & 0.00071 \\
\hline THE - & - Trommel hopper & 0.1295 & 0.01295 \\
\hline T3 & - Fines hopper \& blender (input) & 0.0004 & 0.00004 \\
\hline T4 & - FInes hopper \& blender (output) & 0.0004 & 0.00004 \\
\hline T5 & - Fines Weigh Tank & 0.2000 & 0.02000 \\
\hline V4 & - Discharge conveyor & 0.0240 & 0.00240 \\
\hline$W Q$ & - Wet Quencher & 0.6156 & 0.06156 \\
\hline$O G$ & - Off-Gas Vesisels (VS,EE,ME) & 0.0002 & 0.00002 \\
\hline DI & - Drums being filled & 0.0001 & 0.00010 \\
\hline
\end{tabular}

"Probability of support failure at the estimated acceleration expected for the component.

${ }^{b}$ Actual probability of breach is < IE-5; nevertheless, a conservative probability of 0.1 has been applied to all support fragilities except $B I$ and DI, to provide a total estimated failure probability. 


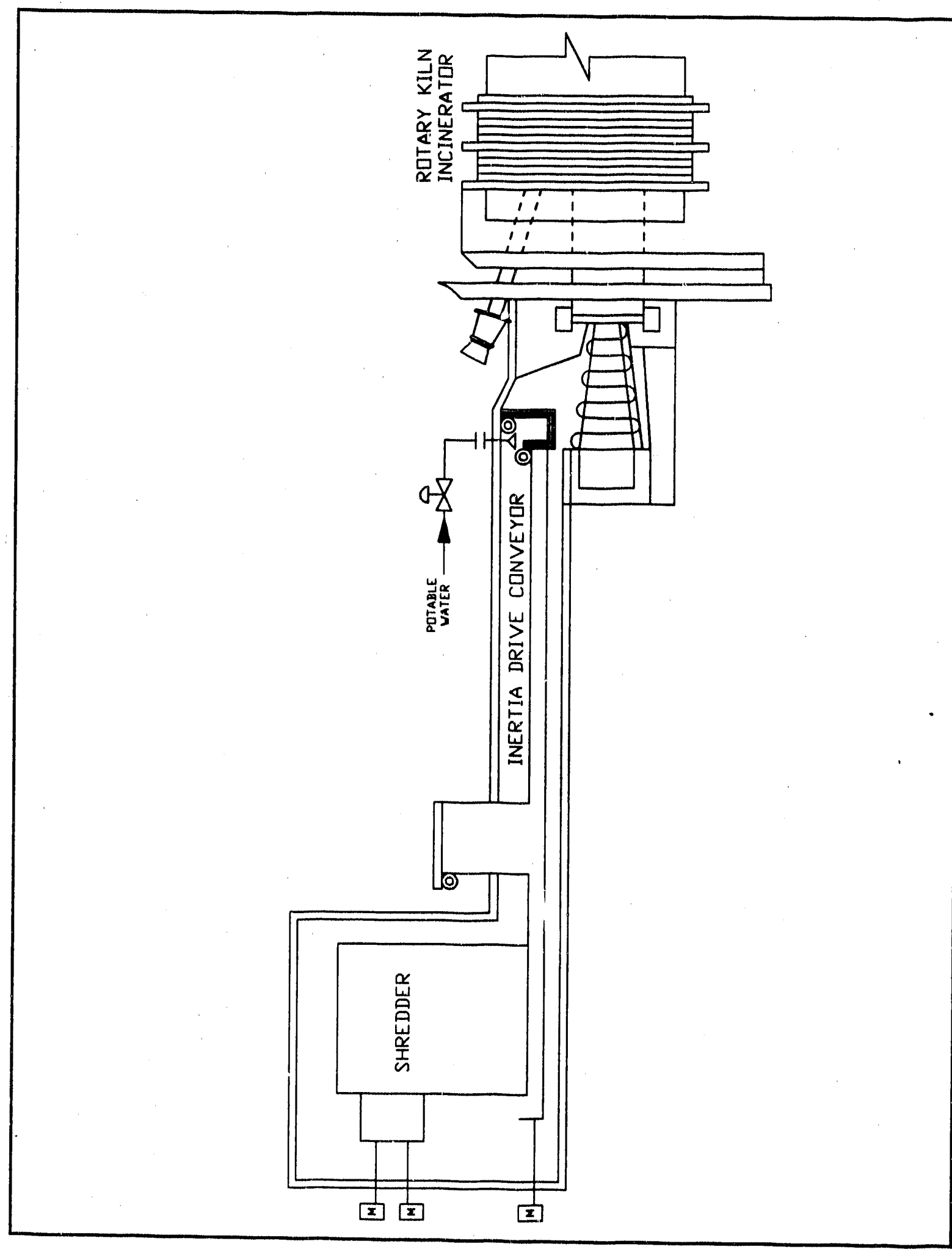

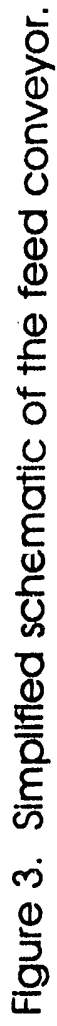




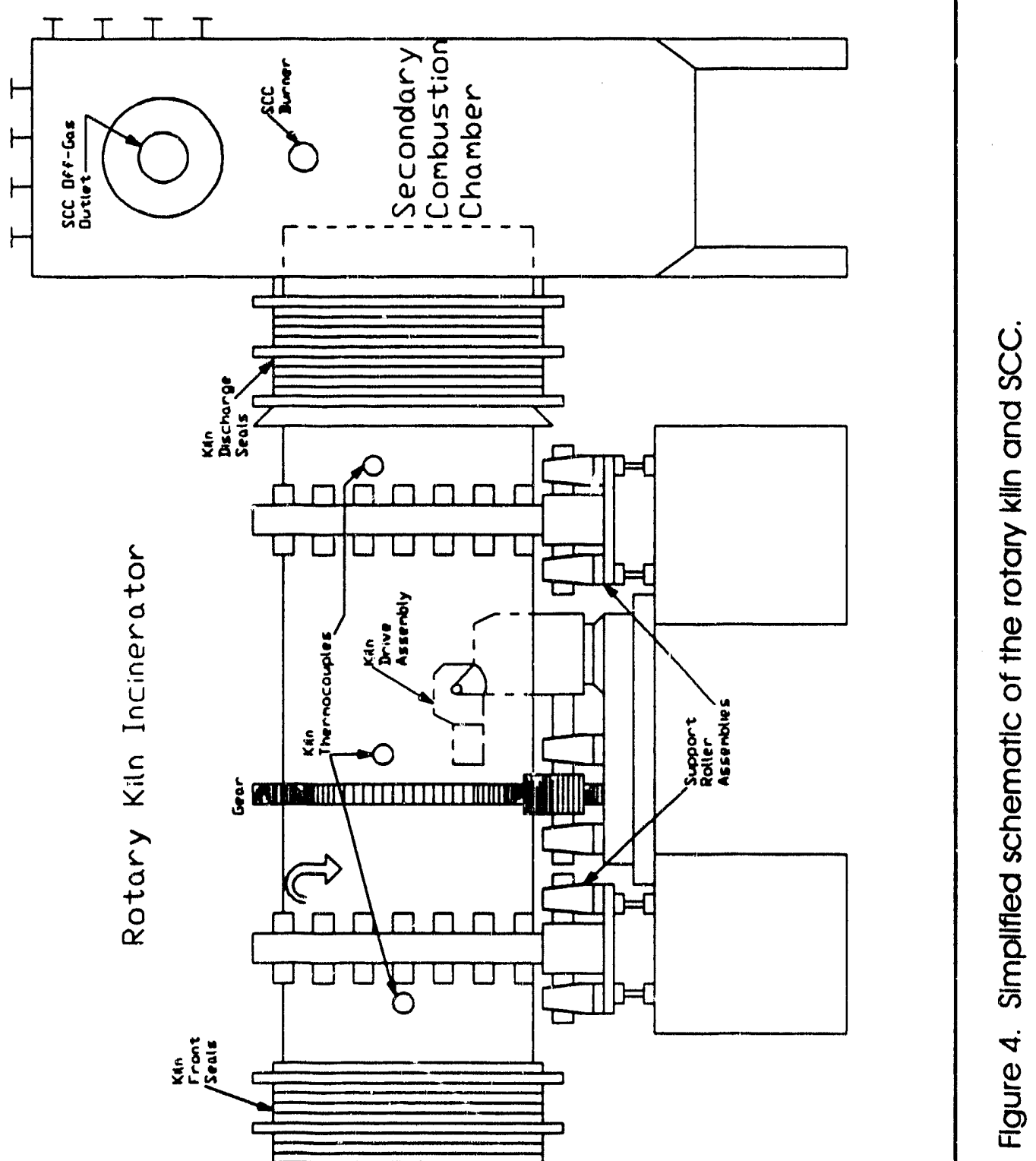


Assumption 15). The fragillty for the klln is lllustrated by the curve in Figure A-2 (Appendlx A). As indicated In Table 4, fallure probabillty for the klln was estimated to be 0.00024 .

\subsubsection{Area 2 Cumponents}

The functlon of this area is to process the off-gas generated by the waste incineration. The off-gas components modeled were the wet quencher, venturl scrubber, entrainment eliminator, and mist ellminator (see Figures 5-8). These components are all located in Room 217.

The wet quencher and venturl scrubber cleanse the off-gas of both particulate and acldic compounds using a sodlum carbonate scrubbing solution. Also, the off-gas is cooled from $\sim 2300^{\circ} \mathrm{F}$ to $\sim 180^{\circ} \mathrm{F}$ by the quencher. The entrainment elliminator and mist ellminator remove the free llquid in the off-gas stream. The wet quencher sits on a spring-type support mounted to a second mezzanine platform. It is also welded to a duct that extends through the adjacent corridor walls into the SCC. Because the venturl scrubber, entrainment ellminator, and mist ellminator are located relatively close to each other and secured with welded plping connections, they were considered in the analysis as one entity. The fragllity for the off-gas vessels is Illustrated by the curve in Figure A-3 (Appendlx A). As Indlcated in Table 4, the fallure probabillty for the quencher was estlmated to be 0.06156; for the three grouped components, 0.0002 .

\subsubsection{Area 3 Components}

The function of this area is to process the llquid by-product from the off-gas cleansing process. The components required for this function are the SRT and assoclated pump (Flgure 9), and the three sludge tanks and their associated hydrocyclone separators and pumps (Figure 10). The Surge Recycle Drain Tank (SRDD and Emergency Draln Tank (EDD) as shown in Figures 11 and 12, respectlvely, are also included in this area. These components are all located in Room 122.

The SRT collects llquids from the area sumps and the off-gas components. For thls analysis, the SRT and its assoclated pump were considered as one entity, mounted to the flrst floor. However, the pump fragillty was negllgible relative to that of the SRT,

\footnotetext{
- Because of the similarity in shape and elevation of the vessels, the same fragility curve represents all four vessels. However, because of limited supports, the quencher was considered more susceptible (i.e., Inore 'fragile' than the other three vessels, which were assumed to fail concurrently.
} 




Figure 5. Simpllfled schematic of the wet quencher. 


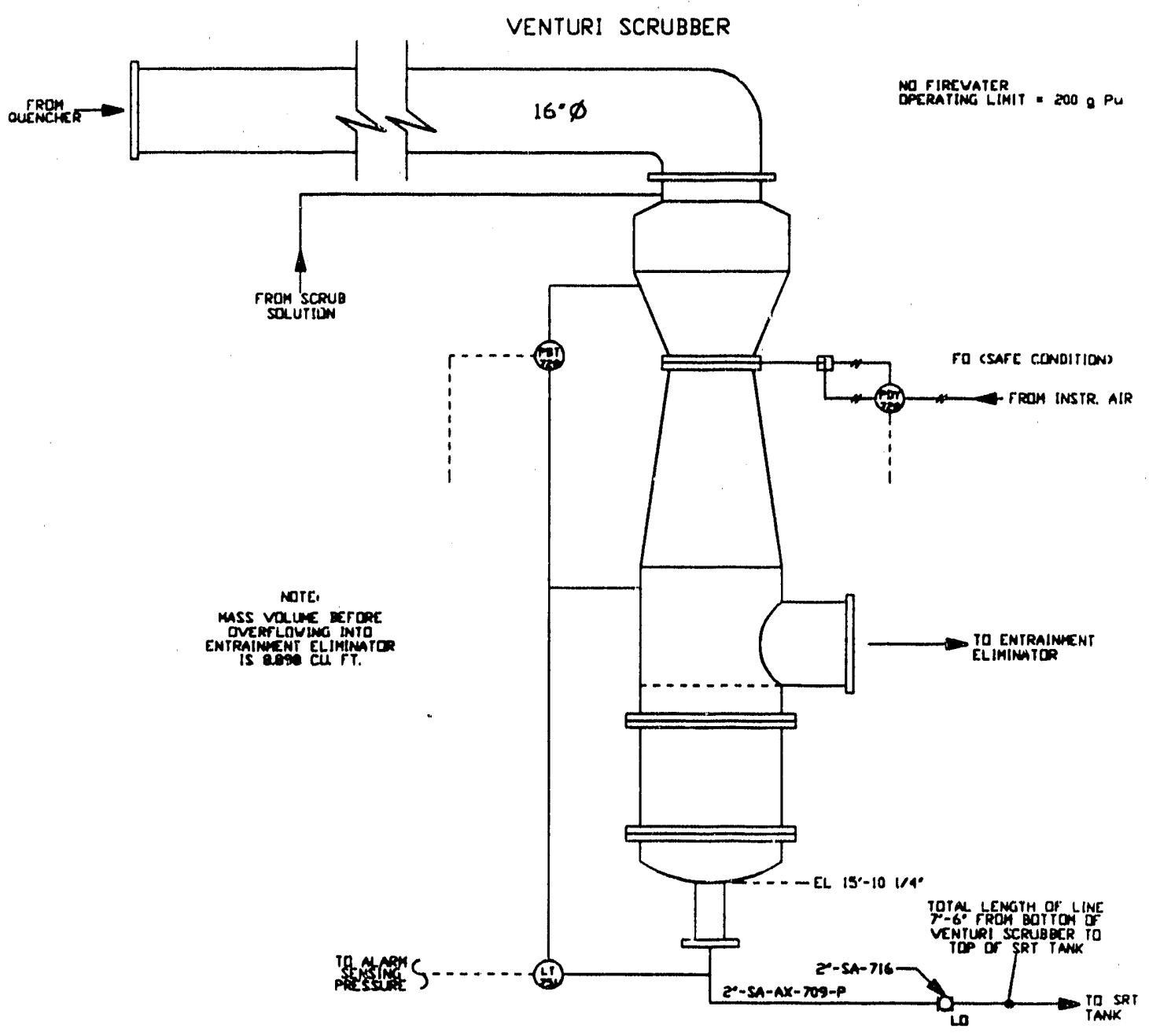

Figure 6. Simplifled schematlc of the venturl scrubber. 


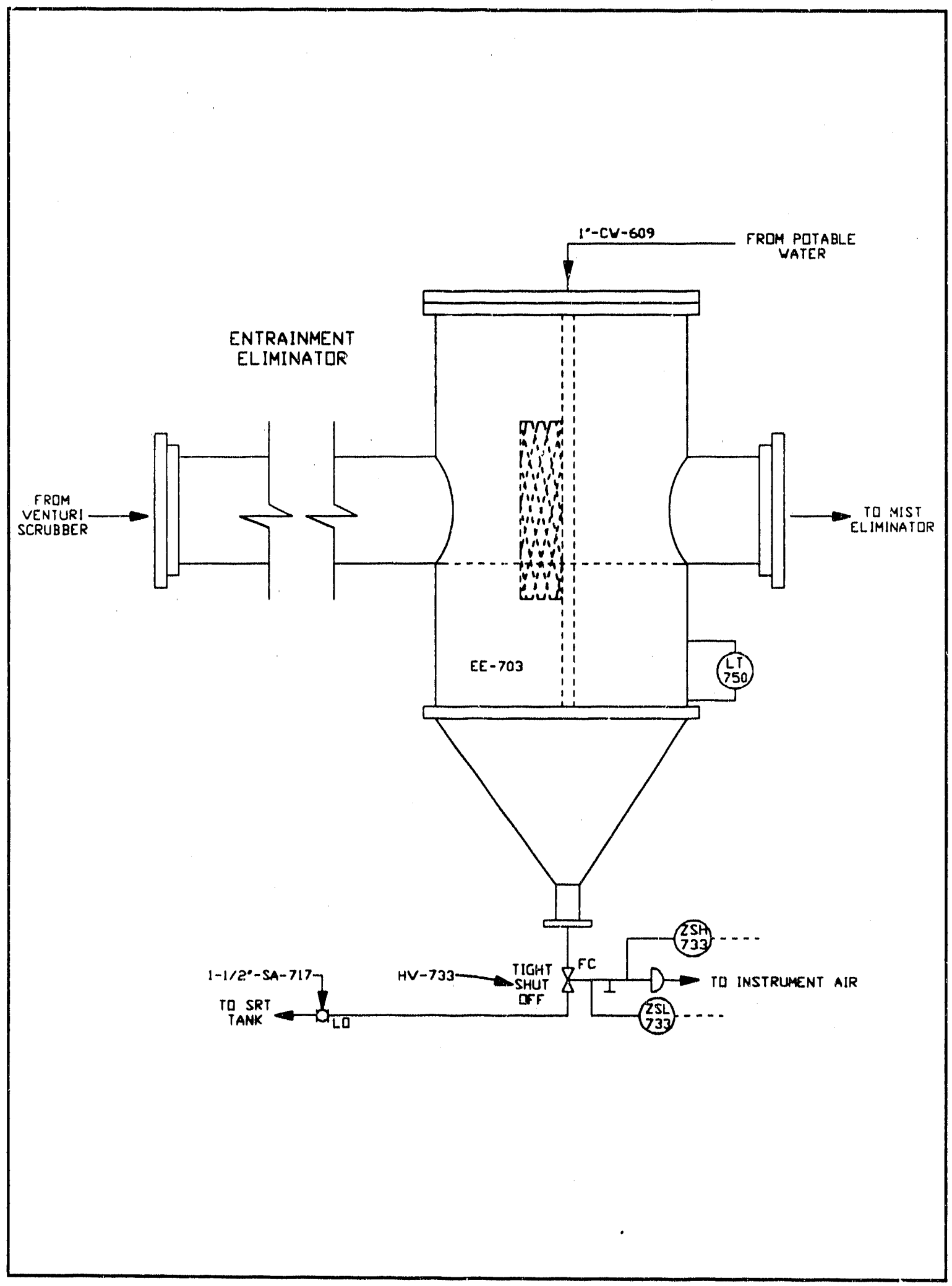

Figure 7. Simplifled schematlc of the entrainment ellminator. 


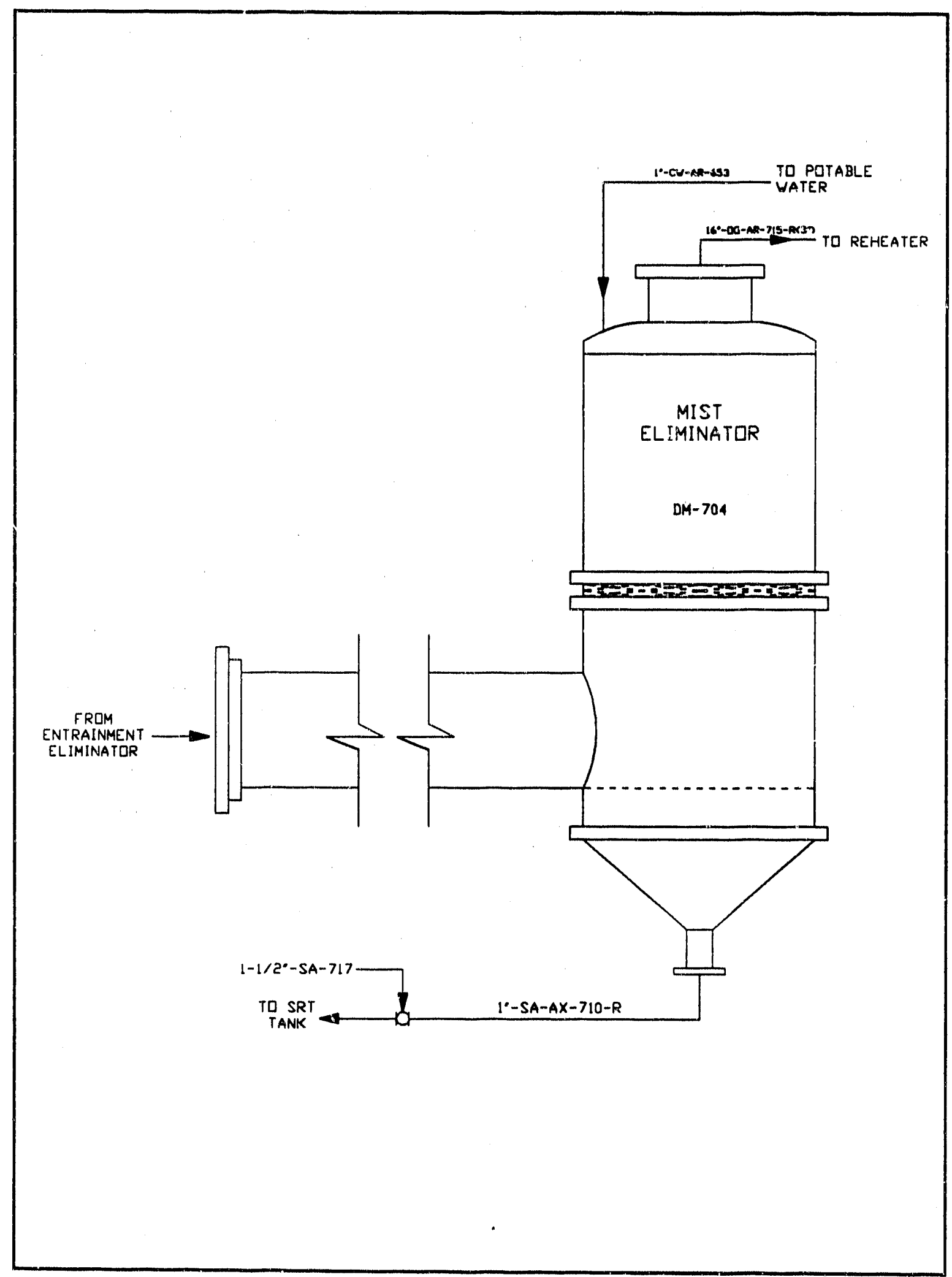

Figure 8. Simplifled schematlc of the mist ellminator. 


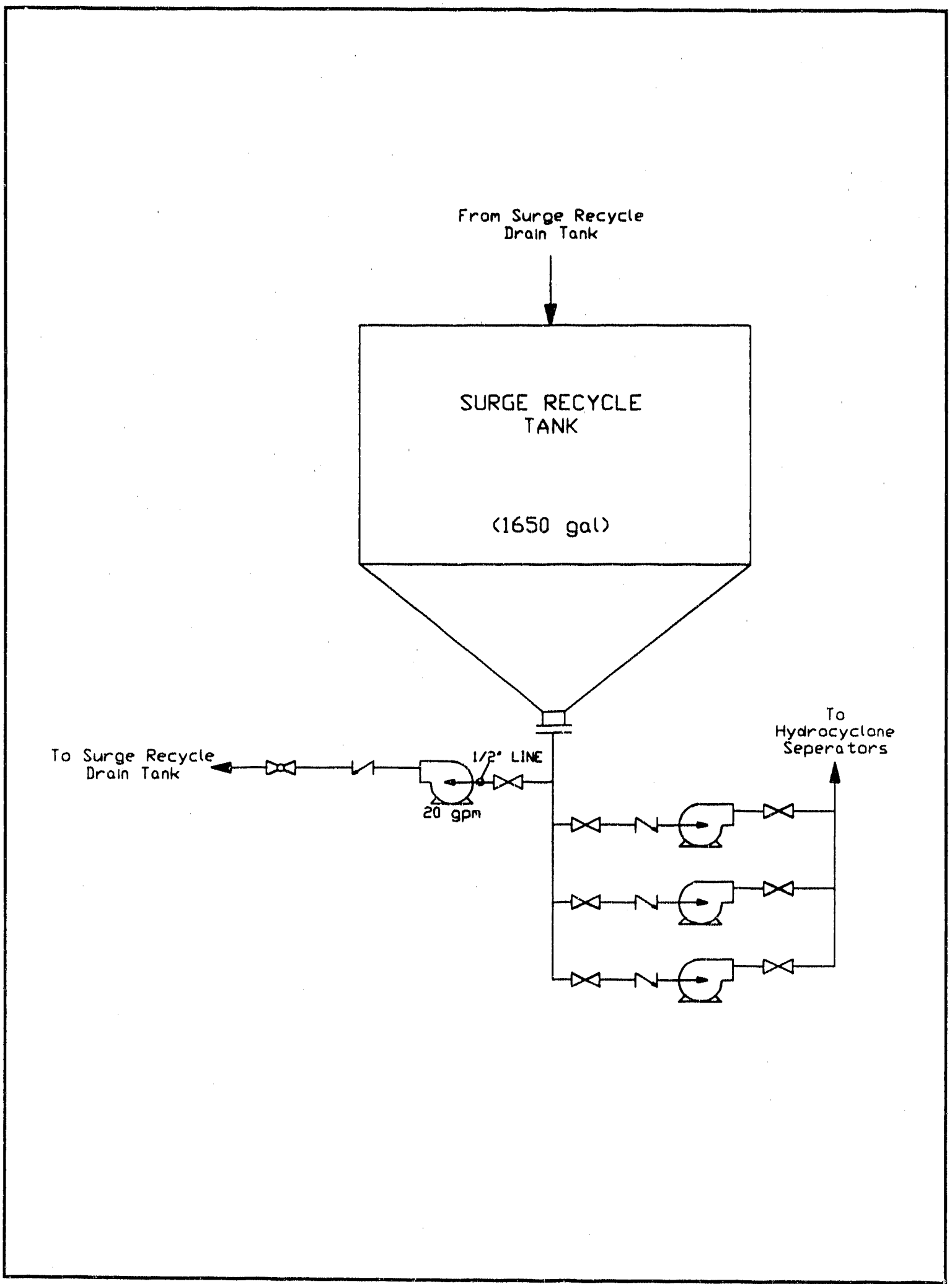

Figure 9. Simpilfled schematic of the surge recycle tank. 




Figure 10. Simplified schematlc of the sludge tanks. 


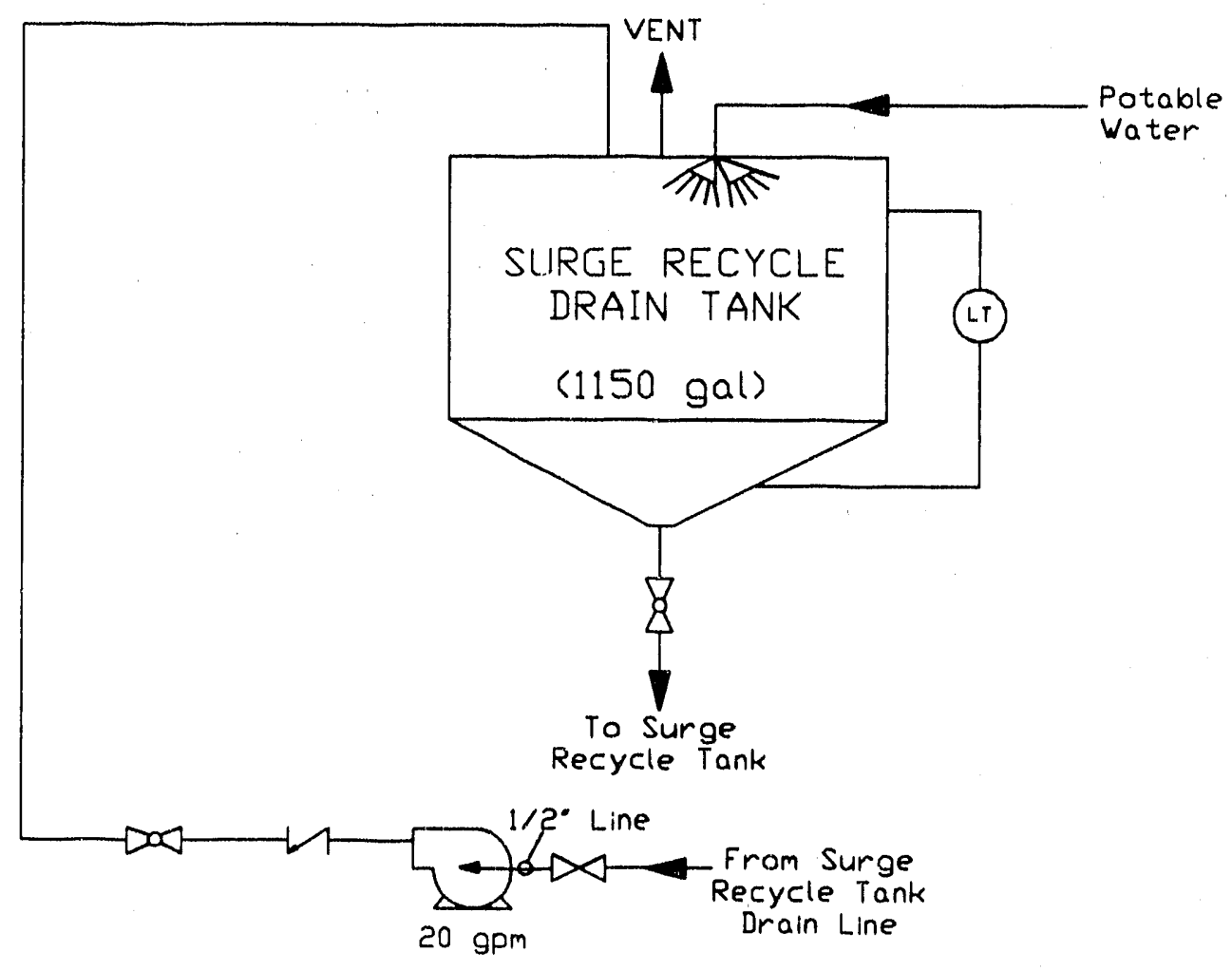

Figure 11. Simplifled schematlc of the surge recycle drain tank. 


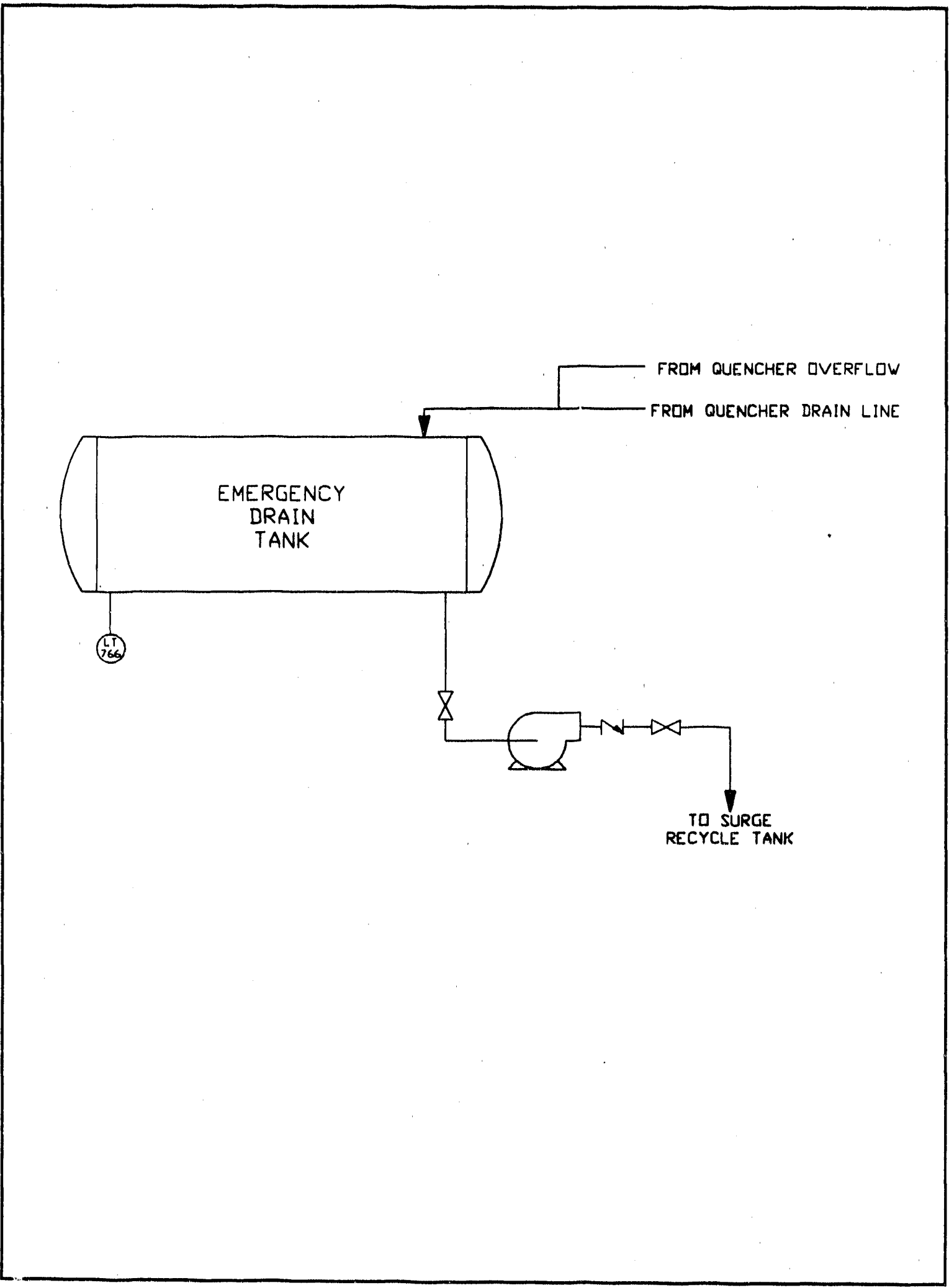

Figure 12. Simplifled schematlc of the emergency drain tank. 
Illistrated by Figure A-4 (Appendlx A), irom this curve, the SRT was assigned the fallure probabllity of 0.01294 (see Table 4).

Normal conflguration of the sludge tanks and assoclated equipment is that one tank is being depleted for grouling; one tank is sparging, walting to be used for grouting; and one is bieing filled from the off-gas cleansing process (see Assumption 4). For purposes of this analysls, the hydrocyclone separators and the sludge tanks are evaluatea as one unit (see Assumption 14). The tank units are mounted to the SRT from the bottom and the off-gas vessels from the top. Addltonal support is provided from structures mounted to the flrst mezzanine (e.g., plping). The fragllity for the sludge tanks is shown by the curve in Figure A-5 (Appendlx A). As indicated In Table 4 , the failure probabillty for the sludge tanks was estimated to be 0.0611 . The pumps assoclated with the sludge tanks that are sparging and grouting were evaluated as separate entitles because the plpes assoclated with these pumps are small and are assumed to rupture with the pumps (see Assumptlon 12). Therefore, the fragillty assoclated with the pumps is shown by the curve in Figure A-6 (Appendix A) and the fallure probabillty for each pump was estimated to be 0.00087 (see Table 4).

The SRDT and EDT are back-up tanks requlred for off-normal situations. Mounted to the first mezzanine, the SRDT and EDT are both illustrated by the curve In Figure A-7 (Appendix A). As indlcated by the flgure and listed in Table 4, the fallure probabllity for both the SRDT and EDT is 0.0611 .

\subsubsection{Area 4 Components}

The function of this area is to process the solid discharge from the klln. The only compone, it required for this function is the discharge conveyor (Flgure 13), which is located in risom 119.

The dlscharge conveyor recelves waste dlscharged from the SCC and transfers it to the trommel hopper (Area 5). The dlscharge conveyor coollng system cools the waste from a maximum entrance temperature of $1800^{\circ} \mathrm{F}$ to less that $180^{\circ} \mathrm{F}$ before dlscharging It to the trommel hopper. On the sldes, the discharge conveyor is mounted to the wall adjacent to the SCC and the drum fill enclosure via the trommel hopper. It also is supported from the first and second floors. The fraglity for the dlscharge conveyor is illustrated by the curve in Figure A-8 (Appendlx A). As indlcated in Table 4, the fallure probability estimated for the discharge conveyor was 0.0024 . 


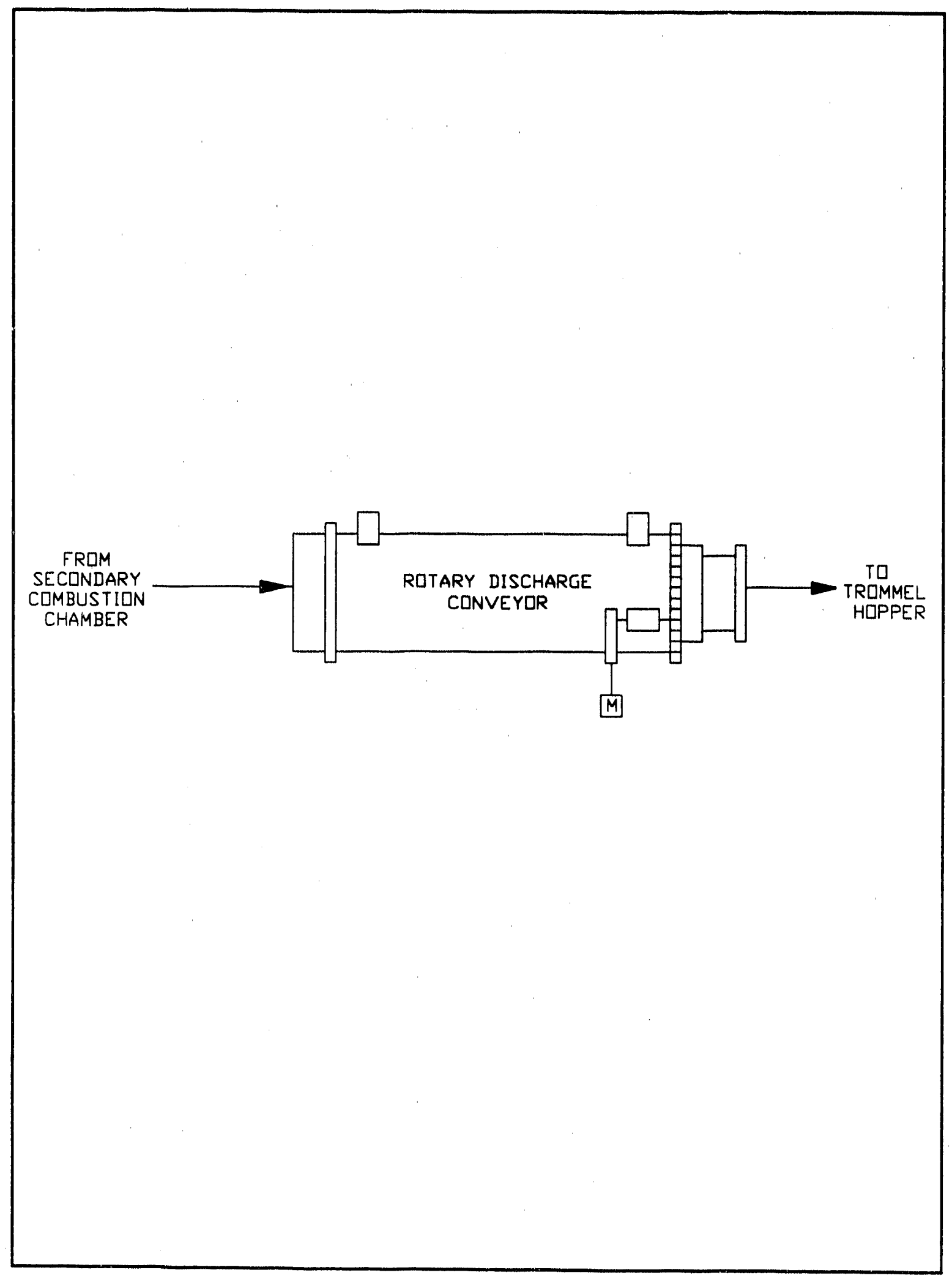

Figure 13. Simplifled schematic of the discharge conveyor. 


\subsubsection{Area 5 Components}

The function of thls area is to process the flnes waste for mlxing with the grout. The components modeled for this function are the trommel hopper, fines hoppers and blender tanks, and fines weigh tank (Figures 14 through 16, respectlvely). This equipment is located in Rooms 118, 119, and 215.

Course waste is separated from the flne ash in the trommel hopper. Waste materlal $<1 / 4^{\prime \prime}$ dlameter and 1" long are processed as fines; and the larger pleces move through the trommel and into the drum flll enclosure. The fine ash is removed from the trommel hopper by a pneumatlc ash conveyor and sent to one of two fines filter hoppers. The fines are dumped from the flnes filter hoppers into the fines blender tanks. Each blender tank contains a mixer to thoroughly blend the fines before being Included in the grout reclpe. The trommel hopper has supports to the dlscharge conveyor, drum fill enclosure, first floor, and basement. The flnes filter hoppers and blender tanks are mounted from the second mezzanine, the second floor, and a first mezzanine platform. The fines welgh tank is welded to plping that is supported by both the second mezzanine anc second floor. The fragllitles for the trommel hopper and the fines hoppers/blender tanks are shown by the curves presented in Figures A-9 and A-10 (Appendlx A), respectlvely. The fragllity for the fines weight tank was calculated from the fragillty data represented by plping and tank fallures. As indlcated in Table 4, the failure probabillties estimated for these components are 0.01295 (trommel hopper), 0.00004 (flnes hoppers/blender tanks, Including the ash conveyor), and 0.02 (flnes welgh tank).

\subsubsection{Area 6 Components}

The functlon of this area is filling the drums with a mixture of waste and grout. This area encompasses the drum enclosure and the drum belng fllled. The filling process takes place in Rooms 118 and 119. The drum enclosure contains only course waste; and it has been assumed that a negllglble amount of plutonlum is in the coarse materlals (see Assumption 2). Therefore, only the drums being filled have been modeled. The fallure probabillty estimated for these drums was 0.0001 (see Table 4) based upon Assumption 18. 


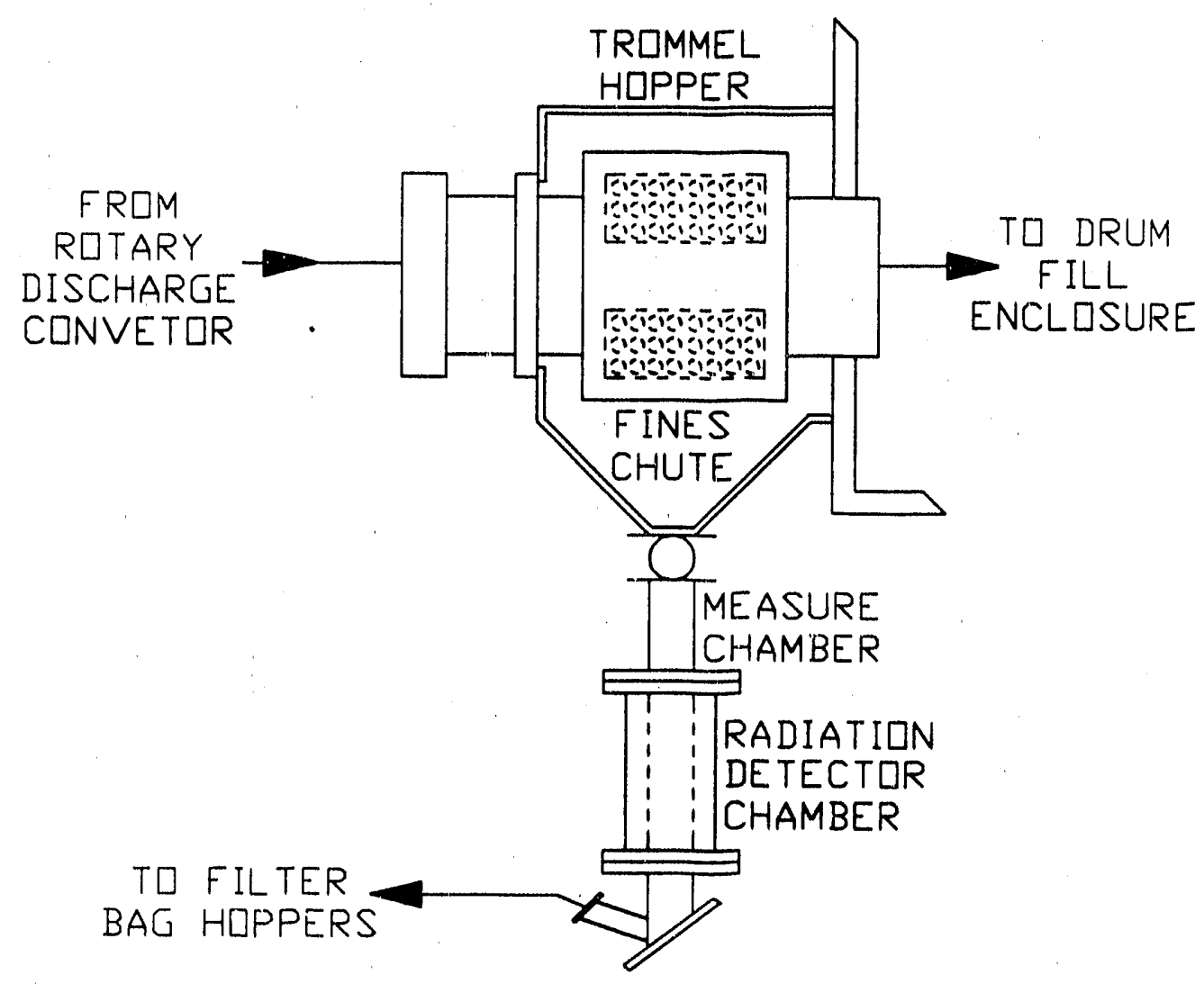

Figure 14. Simplifled schematlc of the trommel hopper. 


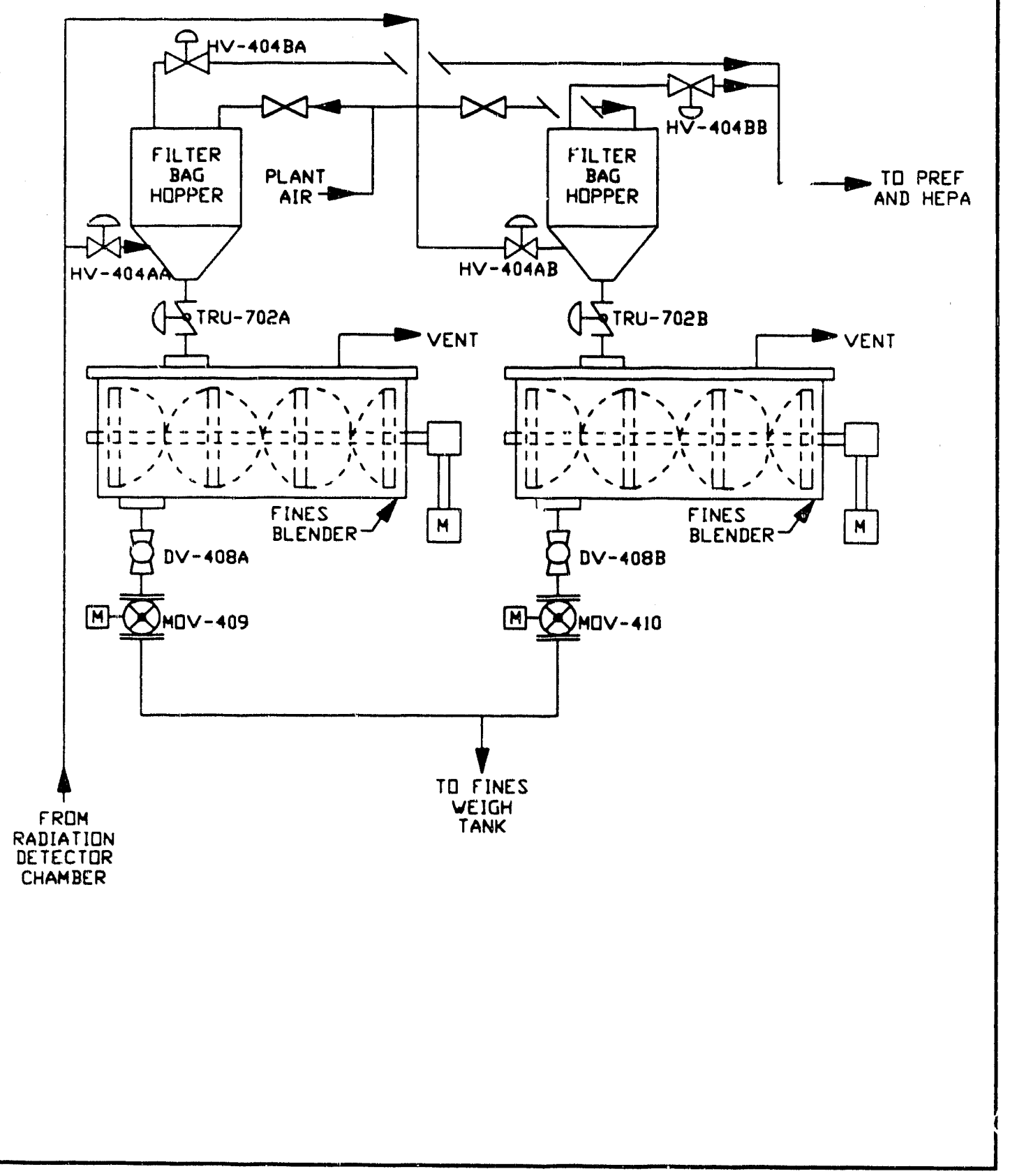

Figure 15. Simplifled schematic of the fines hoppers and blender tanks. 


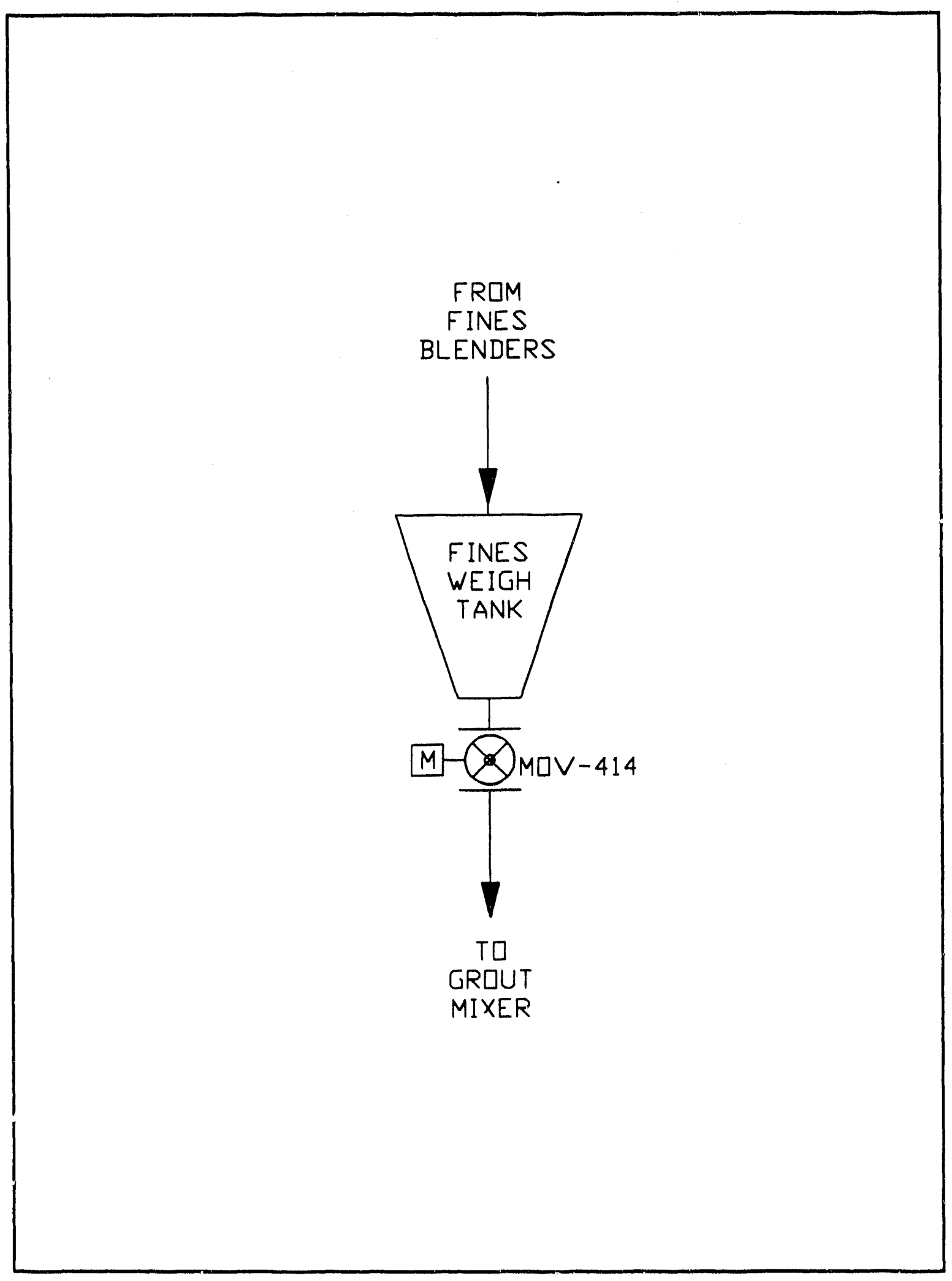

Figure 16. Simplifled schematic of the fines weigh tank. 


\subsubsection{Area 7 Components}

The function of this area is mixing the fines with grout for drum filling. Only the grout mixer tank is required for this functlon (see Figure 17). This tank is located in Room 215. The grout mixer tank takes sand, cement, water, sludge, and plastlcizer to produce grout for fllling the waste drums. The grout mixer supports are mounted to the second floor. The fragillty for the grout mixer tank is represented by the curve in Figure $A-11$ (Appendix A). As indicated in Takle 4, the fallure probabillty estimated for the grout mixer tank was 0.00071 .

\subsubsection{Area 8 Components}

The functlon of this area is curing the grout-fllled drums. Once the drums have been filled, they are moved to Room 112 to cure. The only source of release in the curing process is breach of the drums; and this fallure probabillty has been estimated, calculated from the maximum number and locations of drums expected in this room (see Assumption 19), to be 0.017 .

\subsubsection{Area 9 Components}

The function of this area is to provide negatlve pressure boundarles within the faclilty. This is accompllshed using orie HVAC blower. The fallure probabillity for this blower was estimated to be 0.39 based upon the estimated avallabillty of electrlc power during the seismlc event (Assumptions 5 and 6 ). 




Figure 17. Simplifled schematlc of the grout mixer tank. 


\subsection{EVENT TREE ANALYYSIS}

\subsection{Introduction}

Event tree analysis is a PRA technique for systematically modeling and evaluating accident scenarios. It possesses a unique abllity to address the sequential nature that is inherent in consequences resulting from a selsmlc event. The overall process involved development of accldent scenarlos and entering the scenarios into the computerized event tree modeling code. Riskman (Ref. 54). Once a complete model was developed, the fragillty curves provlded the probabllity data needed for quantification of the event tree model. The quantification process provided insight into the dominant accldent scenarlos, l.e. , the ones with the highest frequencles. The source term, environmental conditions, and fallures for the areas represented by the dominant accident scenarios were then evaluated to determine the condition of the facllity following such events, l.e., facllity damage state.

\subsection{Accident Scenarlo Development}

Initially, scenarios were postulated for each room in the facllity. A precursory look at the resultant scenarios, however, indicated numerous scenarlos with negliglble contribution to any potentlal release. The facllty was then dlvided into functional areas, including all applicable equipment. The areas correspond to those discussed in the systems analysls section, Section 3.3. These functional areas were evaluated and reduced in order to obtain reallstlc scenarios that represented potentlal risk to the faclity personnel or to the environment (and, subsequently, the publlc). Event trees for each of these areas are illustrated in Appendlx B. Figures B-1 through B-9.

\subsection{Dominant Accident Sequences}

The event tree models Illustrated in Appendlx B were quantifled using probabillties from the systems analysis fragillty data (see Section 3.0). For PREPP, the models were separated into two categorles: (1) only llquld release (Areas 3) and (2) poteninl alrborne release (Areas 1,2,4, and 5). Because the Category (1) releases would have not apparent environmental impact, dominant accident sequences* were selected from the Category (2) scenarlos. Detalls of these dominant accident sequences,

\footnotetext{
"Dominant accident sequences were identified as those with probabilities greater than $1 E-6$ when HVAC' succeeded and greater that $1 E-7$ when HVAC failed.
} 
evaluated with and without the HVAC system, are presented in Tables 5 and 6 , respectively. Dominant sequences involve the multipllcation (Indlcated by the asterlsks, "') of the fallure probabilltles of partlcular components and the success probabilltles of other components. In Tables 5 and 6 , fallures are indlcated with a slash preceding the component acronym (e.g., /WQ).

In tharacterizing these 12 dominant sequences with respect to source term quantitles, the estimates in Table 7 were used. The numbers in Table 7. were derlved from Reference 55. These source term estimates were then integrated with equipment fallures and environmental conalitions for determining total facllity damage state conditlons for each dominant accldent sequence. These facillty damage states were further integrated in the consequence model described in Sectlon 5.0. 
SEQUENCE NAME

QUENCHER FAILS

\section{ACCIDENT SEQUENCE}

FC"KL"V4"/WQ"OG'THE"T3"T4*T5"BI

\section{Sequence Breakdown}

$F C=$ Success of fe日d conveyor

$\mathrm{KL}=$ Success of $\mathrm{klln} \& \mathrm{SCC}$

$\mathrm{VA}=$ Success of discharge conveyor

$\mathrm{WW}=$ Failure of wet quencher

$O G=$ success of off-gas vessels

THE = Success of trommel hopper

T3 = Success of fines blender (Input)

T4 = Success of fines blender (output)

T5 = Success of fines weigh tank

$B 1=$ Success of HVAC
FREQUENCY

5.3837E-05
FINES WEIGH TANK FAILS

TROMMEL HOPPER FAILS

\section{FC'KL'V4*WQ'OG'THE'T3"T4*/T5"B1}

Sequence Breakdown

$F C=$ Success of feed conveyor

$\mathrm{KL}=$ Success of kiln \& SCC

$\mathrm{V} 4$ = Success of discharge conveyor

$W Q=$ success of wet quencher

$O G$ = success of off-gas vessels

THE = Success of trommel hopper

T3 = Success of fines blender (input)

T4 = Success of fines blender (output)

$/ T 5=$ Fallure of fines weigh tank

$B I=$ success of HVAC
Probability

9.9647E-01

$9.9976 \mathrm{E}-01$

9.9760E-01

$6.1560 \mathrm{E}-02$

9.9977E-01

9.8705E-01

9.9996E-01

$9.9996 \mathrm{E}-01$

9.8000E-01

9.1000E-01

$1.6749 \mathrm{E}-05$

Probabillty

9.9647E-01

9.9976E-01

9.9760E-01

$9.3844 E-01$

9.9977E-01

9.8705E-01

9.9996E-01

9.9996E-01

2.0000E-02

9.1000E-01

\section{FC"KL・V4*WQ*OG*/THE"T3*T4"T5 ${ }^{\circ} B 1$}

\section{Sequence Breakdown}

$F C=$ Success of feed conveyor

$\mathrm{KL}=$ Success of kiln \& SCC

$V 4=$ Success of discharge conveyor

$W Q=$ Success of wet quencher

$O G=$ success of off-gas vessels

/THE = Failure of trommel hopper

T3 = Success of fines blender (input)

T4 = Success of fines blender (output)

$T 5=$ Success of fines weigh tank

$B 1$ = Success of HVAC
Probabillty

9.9647E-01

9.9976E-01

9.9760E-01

9.3844E-01

9.9977E-01

$1.2950 \mathrm{E}-02$

9.9996E-01

9.9996E-01

9.8000E-01

9. 1000E-01 
TABLE 5. CONCLUDED.

SEQUENCE NAME

FEED ENCLOSURE FAILS
ACCIDENT SEQUENCE

/FC"KL"V4"WQ"OG"THE"T3"TA"T5"B1
FREQUENCY

2.9074E-06

Probability

3.5300E-03

9.9976E-01

9.9760E-01

9.3844E-01

9.9977E-01

9.8705E-01

9.9996E-01

$9.9996 \mathrm{E}-01$

9.8000E-0I

9. 1000E-01

DISCHARGE CONVEYOR FAILS

FC"KL"/V4"WQ'OG・THE"T3*Y4"T5"B1

$1.9744 E-06$

Sequence Breakdown

$F C=$ Success of feed conveyor

$\mathrm{KL}=$ Success of kiln \& SCC

N4 = Failuie of discharge conveyor

$W Q=$ Success of wet quencher

$O G=$ success of off-gas vessels

THE = Success of trommel hopper

$T 3$ = Success of fines blender (input)

$T 4$ = Success of fines blender (output)

$T 5=$ success of fines weigh tank

$B 1$ = Success of HVAC
Probabillty

9.9647E-01

9.9976E-01

2.4000E-03

9.3844E-01

9.9977E-01

9.8705E-01

$9.9996 \mathrm{E}-01$

9.9996E-01

$9.8000 \mathrm{E}-01$

9.1000E-01

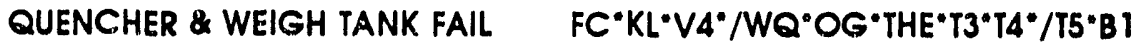

$1.0987 E-06$

Sequence Breakdown

$$
\begin{aligned}
F C & =\text { Success of feed conveyor } \\
K L & =\text { Success of kiln \& SCC } \\
V 4 & =\text { Success of discharge conveyor } \\
\text { SW } & =\text { Failure of wet quencher } \\
O G & =\text { Success of off-gas vessels } \\
T H E & =\text { Success of trommel hopper } \\
T 3 & =\text { Success of fines blender (input) } \\
T 4 & =\text { Success of fines blender (output) } \\
/ T 5 & =\text { Failure of fines weigh tank } \\
B 1 & =\text { Success of HVAC }
\end{aligned}
$$

Probability

9.9647E-01

$9.9976 \mathrm{E}-01$

$9.9760 \mathrm{E}-01$

$6.1560 \mathrm{E}-02$

$9.9977 \mathrm{E}-01$

9.8705E-01

9.9996E-01

$9.9996 E-01$

2.0000E-02

$9.1000 E-01$ 
TABLE 6. ACCIDENT SCENARIO AND RELEASE FREQUENCY SUMMARY WITH HVAC FAILURE

SEQUENCE NAME

QUENCHER FAILS
ACCIDENT SEQUENCE

FC"KL"V4"/WQ*OG'THE'T3*T4"T5*/BI

Sequence Breakdown

$F C=$ Success of feed conveyor

$\mathrm{KL}=$ Success of kiln \& SCC

$\mathrm{V} 4$ = Success of discharge conveyor

$M Q=$ Fallure of wet quencher

$O G=$ success of off-gas vessels

THE = Success of trommel hopper

T3 = Success of fines blender (input)

$T 4$ = Success of fines blender (output)

T5 = Success of fines weigh tank

$|B|=$ Failure of HVAC
FREQUENCY

5.3246E-06

Probability

9.9647E-01

9.9976E-01

9.9760E-01

6.1560E-02

9.9977E-01

9.8705E-01

9.9996E-01

9.9996E-01

9.8000E-01

9.0000E-02

FINES WEIGH TANK FAILS

FC"KL"V4"WQ"OG'THE"T3*T4*/T5"/B I

$1.6565 E-06$

Sequence Breakdown

Probabllity

$F C=$ success of feed conveyor

$\mathrm{KL}=$ Success of kiln \& SCC

9.9647E-01

9.9976E-01

$V 4=$ Success of discharge conveyor

$W Q=$ success of wet quencher

9.9760E-01

$O G$ = success of off-gas vessels

9.3844E-01

9.9977E-01

THE = Success of trommel hopper

9.8705E-01

$\mathrm{T} 3=$ Success of fines blender (input)

9.9996E-01

$T 4=$ Success of fines blender (output)

$9.9996 \mathrm{E}-01$

$/ T 5=$ Failure of fines weigh tank

$2.0000 E-02$

$|B|=$ Failure of HVAC

$9.0000 \mathrm{E}-02$

TROMMEL HOPPER FAILS

FC"KL"V4"WQ*OG*/THE"T3"T4"T5"/BI

1.0649E-06

\section{Sequence Breakdown}

$F C=$ Success of feed conveyor

$\mathrm{KL}=$ Success of kiln \& SCC

$\mathrm{V4}=$ Success of discharge conveyor

$W Q=$ success of wet quencher

$O G=$ success of off-gas vessels

$/ T H E=$ Failure of trommel hopper

$\mathrm{T} 3$ = Success of fines blender (input)

$\mathrm{T} 4$ = Success of fines blender (output)

T5 = Success of fines weigh tank

$|B|=$ Failure of HVAC
Probability

9.9647E-01

$9.9976 \mathrm{E}-01$

9.9760E-01

9.3844E-01

9.9977E-01

$1.2950 \mathrm{E}-02$

$9.9996 \mathrm{E}-01$

$9.9996 \mathrm{E}-01$

9.8000E-01

9.0000 E-02 
TABLE 6. CONCLUDED.

SEQUENCE NAME

FEED ENCLOSURE FAILS
ACCIDENT SEQUENCE

/FC"KL'V4"WQ*OG'THE"T3*T4"T5*/B I

Sequence Breakdown

$/ F C=$ Fallure of feed conveyor

$\mathrm{KL}=$ Success of kiln \& SCC

$V 4=$ success of discharge conveyor

$W Q=$ Success of wet quencher

$O G=$ Success of off-gas vessels

THE = Success of trommel hopper

T3 = Success of fines blender (input)

$T 4$ = Success of fines blender (output)

T5 = Success of fines weigh tank

$|B|=$ Failure of HVAC
FREQUENCY

2.8754E-07

Probability

3.5300E-03

9.9976E-01

9.9760E-01

9.3844E-01

9.9977E-01

9.8705E-01

$9.9996 \mathrm{E}-01$

$9.9996 \mathrm{E}-01$

$9.8000 \mathrm{E}-01$

$9,0000 \mathrm{E}-02$

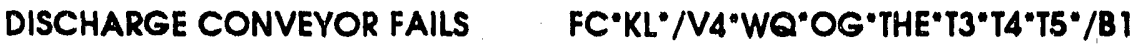

1.9527E-07

Sequence Breakdown

Probability

$F C=$ Success of feed conveyor

$\mathrm{KL}=$ Success of kiln \& SCC

9.9647E-01

N4 = Failure of discharge conveyor

9.9976E-01

$W Q=$ success of wet quencher

$2.4000 E-03$

$O G=$ success of off-gas vessels

9.3844E-01

THE = Success of trommel hopper

9.9977E-01

T3 = Success of fines blender (input)

9.9705E-01

T4 = Success of fines blender (output)

9.9996E-01

9.9996E-01

T5 = Success of fines weigh tank

$9.8000 E-01$

$|B|=$ Failure of HVAC

$9.0000 E-02$

QUENCHER \& WEIGH TANK FAIL FC"KL"V4*/WQ'OG"THE*T3*T4*/T5*/B1

$1.0866 \mathrm{E}-07$

Sequence Breakdown

Probability

$F C=$ Success of feed conveyor

9.9647E-01

$\mathrm{KL}=$ Success of kiln \& SCC

9.9976E-01

$V_{4}=$ Success of discharge conveyor

$9.9760 \mathrm{E}-01$

$M Q=$ Failure of wet quencher

$6.1560 \mathrm{E}-02$

$O G$ = success of off-gas vessels

9.9977E-01

THE = success of trommel hopper

9.8705E-01

T3 = Success of fines blender (input)

9.9996E-01

T4 = Success of fines blender (output)

9.9996E-01

$/ T 5=$ Failure of fines weigh tank

$|B|=$ Failure of HVAC

$2.0000 E-02$

$9.0000 E-02$ 


\begin{tabular}{|c|c|c|c|}
\hline PREPP Area & Total Grams & Release Fraction & Alrborne Grams \\
\hline Feed & 592.0 & $5 E-4$ & 0.30 \\
\hline Off-Gas & 500.0 & $5 E-4$ & 0.25 \\
\hline Llquid & 3837.0 & 0.00 & 0.00 \\
\hline Solld & 64.5 & $5 E-4$ & 0.03 \\
\hline Fines & 2240.0 & $5 E-4$ & 1.12 \\
\hline Filling & 21.5 & 0.00 & 0.00 \\
\hline Mixing & 63.0 & 0.00 & 0.00 \\
\hline Curing & 860.0 & 0.00 & 0.00 \\
\hline
\end{tabular}




\subsection{CONSEQUENCE ANALYSIS}

In this analysis, the characterlstlcs of each accident scenario (l.e., facillty damage state) were consolldated with facillty internal environmental conditlons to model alspersion of the estimated alrborne source term within the facllity and the amount that could potentlally be released to the environment. In a prelliminary analysis effort, potentlal radiologlcal consequences for the postulated PREPP accidents were calculated based on the RSAC-4 computer code (Ref. 56). The calculated doses Included inhalation and air Immersion pathways, represeriing committed effectlve dose equivalents (l.e., fractlon of radlonuclldes retalned in the body for 50 years following the perlod of Intake). Following these preliminary results, a more in-depth analysls was performed to obtain more reallstic quantitles than the original conservative estimates of source term. A complex transport computer modeling code was used in the final consequence analysis. A presentation of the details and results of the consequence analysis follows.

Varlous consideratlons were included In developing the computer model used in this analysis (MELCOR, Ref. 57). Partlcularly close attention was pald to the modelling of temperatures, pressures, and heat structures (l.e., floors, cellings, and walls). No credlt was taken for the TAN structure whlch houses the PREPP facillty, l.e., any releases from PREPP were assumed to be to the environment.

In creating the model for thls analysis, the PREPP facillty was dlvided into 12 areas called control volumes: 11 representing the 39 rooms in the facillty, and 1 representing the environment. Table 8 provides the designation for the 12 control volumes and the rocms represented by each.

Because of the unlque differences implled by the success or fallure of HVAC, two models were developed--one to represent the sequences with HVAC success (see Table 5); the other to represent the sequences with HVAC fallure (see Table 6). For HVAC success, 44 flow paths throughout the facllity were modeled; for HVAC fallure, 28 flow paths. These flow paths were modeled to represent the small gap around closed doors, assumed to have a size corresponding to the full circumference of the door $(2 \mathrm{~mm})$, creating an opening of $0.012 \mathrm{~m}^{2}$ per door. Flow cath length was assumed to be $0.1 \mathrm{~m}$ (approximate thickness of the door). A conservative assumptlon that no flow restrictions exist in any control volume is also included in the model. With 


\begin{tabular}{ccc} 
CONTROL VOLUME & ROOMS INCLUDED & DESIGNATION \\
\cline { 2 - 3 } & none & Environment \\
2 & $104,109,110$ & Feed Conveyor \\
3 & $105,106,107,203$ & Overpack Area \\
4 & $108,117,118,119, \mathrm{M}-102$ & Drum Fill Area \\
5 & $111,112,115,116$ & Drum Curing \\
6 & 120 & Kiln/SCC \\
7 & $121,122, M-103,201,217, S 3$ & Off-Gas Equipment \\
8 & $202,206,218, S 1, S 11$ & Gallery \\
9 & $204,205,210,218, M-201$ & Shredder Rooms \\
10 & $207,208,209, M-202, S 2$ & Personnel Decon. \\
11 & 211 & Control Room \\
12 & $213,214,215$ & Fines Storage/ \\
& & Handling
\end{tabular}

${ }^{a}$ ' $M$ ' indicates a mezzanine; ' $S$ ' indicates stairs.

the exception of Control Volume 11 (Control Room), each control volume contalns at least two flow paths.

Each control volume also has numerous assoclated heat structures. All floors, walls, and cellings were included in thls parameter, to create a total of 109 heat structures. Elght different structure types are represented, dependent on material composition, thlckness, and communication. Most walls interlor to the confinement were modeled as adlabatic, l.e., no heat conduction. All perimeter walls and the walls of the klln were modeled to allow one-dimenslonal conductlon between control volumes, with convection on both sides of the walls. 
Each of the 12 accident scenarlos were modeled, with assoclated source term and fallures, to determine dispersion/transport of the source term. Tables 9 through 20 present the results of the 12 accldent scenarlos. In the slx models representing HVAC success (Tables 9 - 14), the 12 control volumes were connected by velocity controlled flow paths. A unlform size of $1 \mathrm{~m}^{2}$ and a constant velocity in concert with the HVAC system flow rates was chosen for each of the 44 flow paths in this model. No consideration was included, however, for the removal efflclency of the HEPA filters through which the aerosol would pass before belng released to the environment. Therefore, a HEPA fllter efflclency factor of $99.97 \%$ should be applled to the source term Indlcated in these tables (Tables 9-14) to obtain the actual source term potentlally released to the environment.

The remaining six tables, Tables 15 through 20, represent the scenarlos from Table 6 (l.e.. HVAC fallure). In these scenarios, the release was not through the HEPAs; aerosols were assumed to be released to the environment through seal openings around doors. Therefore, no additional credlt or reductions can be applled to the source term quantitles presented in these tables (Tables 15 - 20). 
TABLE 9. TRANSPORT RESULTS FOR HVAC SUCCESS ACCIDENT SCENARIO 1.

\begin{tabular}{|c|c|c|c|}
\hline CONTROL VOLUME & ROOMS INCLUDED & $\frac{\text { PEAK QUANTITY }}{\text { OF Pu }(k g)^{\mathrm{b}}}$ & $\frac{\text { PINAL QUANTIIY }}{\text { OF PU }(\mathrm{kg})^{\mathrm{D}}}$ \\
\hline 1 & none & 0.000010 & 0.000010 \\
\hline 2 & 104.109 .110 & 0.000000 & 0.000000 \\
\hline 3 & 105.106 .107 .203 & 0.000000 & 0.000000 \\
\hline 4 & $108.117 .118 .119 . \mathrm{M}-102$ & 0.000013 & 0.000000 \\
\hline 5 & 111.112 .115 .116 & 0.000000 & 0.000000 \\
\hline 6 & 120 & 0.000000 & 0.000000 \\
\hline 7 & $121.122 . \mathrm{M}-103.201 .217 .53$ & 0.000000 & 0.000000 \\
\hline 8 & 202.206 .218 .51 .511 & 0.000000 & 0.000000 \\
\hline 9 & $204.205 .210 .218 . M-201$ & 0.006000 & 0.000000 \\
\hline 10 & $207.208 .209 . M-202.52$ & 0.000000 & 0.000000 \\
\hline 11 & 211 & 0.000000 & 0.000000 \\
\hline 12 & 213.214 .215 & 0.000000 & 0.000000 \\
\hline \multicolumn{4}{|c|}{$\begin{array}{l}{ }^{\circ} M \text { ' indicates a mezanine: ' } S \text { ' indicates stairs. } \\
{ }^{\circ} M e a s u r e d \text { from time } 0-10-30 \mathrm{~min} \text {. }\end{array}$} \\
\hline
\end{tabular}

TABLE 10. TRANSPORT RESULTS FOR HVAC SUCCESS ACCIDENT SCENARIO 2

\begin{tabular}{|c|c|c|c|}
\hline CONTROL VOLUME & ROOMS INCLUDED & $\frac{\text { PEAK QUANTITY }}{\text { OF PU (kg) }}$ & $\frac{\text { FINAL QUANTITY }}{\text { OF PU (kg) }}$ \\
\hline \multicolumn{4}{|c|}{ (1) } \\
\hline 2 & none & 0.000035 & 0.000035 \\
\hline 3 & $104,109.110$ & 0.000000 & 0.000000 \\
\hline 4 & 105.106 .107 .203 & 0.000000 & 0.000000 \\
\hline 5 & $108.117 .118 .119 . \mathrm{M}-102$ & 0.000047 & 0.000047 \\
\hline 6 & 111.112 .115 .116 & 0.000001 & 0.000001 \\
\hline 7 & 120 & 0.000000 & 0.000000 \\
\hline 8 & $121.122 . \mathrm{M}-103.201 .217 . \mathrm{S3}$ & 0.000000 & 0.000000 \\
\hline 9 & 202.206 .218 .51 .511 & 0.000000 & 0.000000 \\
\hline 10 & $204.205 .210 .218, M-201$ & 0.000000 & 0.000000 \\
\hline 11 & $207.208,209, \mathrm{M}-202, \mathrm{~S} 2$ & 0.000000 & 0.000000 \\
\hline \multirow[t]{2}{*}{12} & 211 & 0.000000 & 0.000000 \\
\hline & 213.214 .215 & 0.000000 & 0.000000 \\
\hline $\begin{array}{l}{ }^{\circ} M \text { ' indicate } \\
{ }^{\circ} M e a s u r e d ~ f r c\end{array}$ & $\begin{array}{l}\text { nezzanine: ' } S \text { ' indicates } \\
\text { ime } 0 \text {-to- } 30 \mathrm{~min} \text {. }\end{array}$ & & \\
\hline
\end{tabular}


TABLE 11. TRANSPORT RESULTS FOR HVAC SUCCESS ACCIDENT SCENAIIIO 3

\begin{tabular}{|c|c|c|c|}
\hline CONTROL VOLUME & ROOMS INCLUDED & $\frac{\text { PEAK QUANTITY }}{\text { OF PU }(\mathrm{kg})^{\mathrm{b}}}$ & $\frac{\text { FINAL QUANTITY }}{\text { OF Pu }(\mathrm{kg})^{\mathrm{b}}}$ \\
\hline 1 & none & 0.000045 & 0.000045 \\
\hline 2 & 104.109 .110 & 0.000000 & 0.000000 \\
\hline 3 & $105,106,107,203$ & 0.000000 & 0.000000 \\
\hline 4 & $108.117 .118 .119 . \mathrm{M}-102$ & 0.000060 & 0.000000 \\
\hline 5 & $111,112.115 .116$ & 0.000001 & 0.000001 \\
\hline 6 & 120 & 0.000000 & 0.000000 \\
\hline 7 & $121,122, \mathrm{M}-103,201,217,53$ & 0.000000 & 0.000000 \\
\hline 8 & $202,206,218,51,511$ & 0.000000 & 0.000000 \\
\hline 9 & $204.205,210.218 . M-20 i$ & 0.000000 & 0.000000 \\
\hline 10 & $207.208,209, M-202, S 2$ & 0.000000 & 0.000000 \\
\hline 11 & 211 & 0.000000 & 0.000000 \\
\hline 12 & $213,214,215$ & 0.000000 & 0.000000 \\
\hline \multicolumn{4}{|c|}{ ' $M$ ' indicates a mezzanine; ' $S$ ' indicates stairs. } \\
\hline
\end{tabular}

TABLE 12. TRANSPORT RESULTS FOR HVAC SUCCESS ACCIDENT SCENARIO 4

\begin{tabular}{|c|c|c|c|}
\hline CONTROL VOLUME & ROOMS INCLUDED & $\frac{\text { PEAK QUANTITY }}{\text { OF PU }(K g)^{b}}$ & $\frac{\text { FINAL QUANTITY }}{\text { OF PU }(k g)^{\circ}}$ \\
\hline 1 & none & 0.000018 & 0.000018 \\
\hline 2 & 104.109 .110 & 0.000000 & 0.000000 \\
\hline 3 & $105,106,107,203$ & 0.000000 & 0.000000 \\
\hline 4 & $108,117,118,119 . \mathrm{M}-102$ & 0.000001 & 0.000000 \\
\hline 5 & 111.112 .115 .116 & 0.000000 & 0.000000 \\
\hline 6 & 120 & 0.000004 & 0.000004 \\
\hline 7 & $121,122, M-103,201.217,53$ & 0.000061 & 0.000000 \\
\hline 8 & $202,206.218, S 1,511$ & 0.000000 & 3.000000 \\
\hline 9 & $204.205 .210 .218 . M-201$ & 0.000000 & 0.000000 \\
\hline 10 & $207,208,209, M-202 . \$ 2$ & 0.000000 & 0.000000 \\
\hline 11 & 211 & 0.000000 & 0.000000 \\
\hline 12 & $213,214.2 .15$ & 0.000000 & 0.000000 \\
\hline \multicolumn{4}{|c|}{$\begin{array}{l}{ }^{\circ} M \text { ' indicates a mezzanine: 'S' indicates stairs. } \\
{ }^{\circ} M e a s u r e d \text { from time } 0-10-30 \mathrm{~min} \text {. }\end{array}$} \\
\hline
\end{tabular}


TABLE 13. TRANSPORT RESULTS FOR HVAC SUCCESS ACCIDENT SCENARIO 5

\begin{tabular}{|c|c|c|c|}
\hline CONTROL VOLUME & ROOMS INCLUI)ED & $\frac{\text { PEAK QUANTITY }}{\text { OF PU }(\mathrm{kg})^{\mathrm{b}}}$ & $\frac{\text { FINAL QUANTITY }}{\text { OF Pu }(\mathrm{kg})^{\mathrm{b}}}$ \\
\hline 1 & none & 0.000053 & 0.000053 \\
\hline 2 & $104,109.110$ & 0.000000 & 0.000000 \\
\hline 3 & 105.106 .107 .203 & 0.000000 & 0.000000 \\
\hline 4 & $108,117,118,119 . \mathrm{M}-102$ & 0.000047 & 0.000000 \\
\hline 5 & 111.112 .115 .116 & 0.000001 & 0.000000 \\
\hline 6 & 120 & 0.000004 & 0.000000 \\
\hline 7 & $121,122 . \mathrm{M}-103,201,217 . \mathrm{S3}$ & 0.000061 & 0.000000 \\
\hline 8 & 202.206 .218 .51 .511 & 0.000000 & 0.000000 \\
\hline 9 & $204,205,210,218, M-201$ & 0.000000 & 0.000000 \\
\hline 10 & $207.208 .209 . M-202 . S 2$ & 0.000000 & 0.000000 \\
\hline 11 & 211 & 0.000000 & 0.000000 \\
\hline 12 & 213.214 .215 & 0.000000 & 0.000000 \\
\hline \multicolumn{4}{|c|}{$\begin{array}{l}{ }^{\circ} M \text { ' indicates a mezzanine: 'S' indicates stairs. } \\
{ }^{\circ} M \text { Measured from time } 0-t o-30 \mathrm{~min} \text {. }\end{array}$} \\
\hline
\end{tabular}

TABLE 14. TRANSPORT RESULTS FOR HVAC SUCCESS ACCIDENT SCENARIO 6

\begin{tabular}{|c|c|c|c|}
\hline CONTROI VOLUME & ROOMS INCLUDED & $\frac{\text { PEAK QUANTITY }}{\text { OF PU }(\mathrm{kg})^{\mathrm{b}}}$ & $\frac{\text { FINAL QUANTITY }}{\text { OF PU }(\mathrm{kg})^{\mathrm{b}}}$ \\
\hline 1 & none & 0.000031 & 0.000031 \\
\hline 2 & $104,109,110$ & 0.000069 & 0.000000 \\
\hline 3 & $105,106,107,203$ & 0.000000 & 0.000000 \\
\hline 4 & $108.117 .118 .119 . \mathrm{M}-102$ & 0.000004 & 0.000047 \\
\hline 5 & 111.112 .115 .116 & 0.000004 & 0.000001 \\
\hline 6 & 120 & 0.000005 & 0.000000 \\
\hline 7 & $121,122, M-103,201,2 i 7.53$ & 0.000000 & 0.000000 \\
\hline 8 & 202.206 .218 .51 .511 & 0.000000 & 0.000000 \\
\hline 9 & $204,205,210,218 . M-201$ & 0.000000 & 0.000000 \\
\hline 10 & $2 C 7.208 .209 . M-202.52$ & 0.000000 & 0.000000 \\
\hline 11 & 211 & 0.000000 & 0.000000 \\
\hline 12 & $213,214,215$ & 0.000000 & 0.000000 \\
\hline \multicolumn{4}{|c|}{$\begin{array}{l}\text { 'M' indicates a mezzanine: 'S' indic ates stairs. } \\
{ }^{\circ} M \text { Measured from time' } 0 \text {-to-30 min. }\end{array}$} \\
\hline
\end{tabular}


TABLE 15. TRANSPORT RESULTS FOR HVAC FAILURE ACCIDENT SCENARIO I

\begin{tabular}{|c|c|c|c|}
\hline CONTROL VOLUME & ROOMS INCLUDED & $\frac{\text { PEAK QUANTTYY }}{\text { OF PU }(k g)^{b}}$ & $\frac{\text { FINAL QUANTITY }}{\text { OF PU }(\mathrm{kg})^{\mathrm{b}}}$ \\
\hline 1 & none & 0.000000 & 0.000000 \\
\hline 2 & 104.109 .110 & 0.000000 & 0.000000 \\
\hline 3 & $105.106,107,203$ & 0.000000 & 0.000000 \\
\hline 4 & $108.117 .118 .119, \mathrm{M}-102$ & 0.000014 & 0.000000 \\
\hline 5 & 111.112 .115 .116 & 0.000000 & 0.000000 \\
\hline 6 & 120 & 0.000000 & 0.000000 \\
\hline 7 & $121.122 . \mathrm{M}-103,201.217 .53$ & 0.000000 & 0.000000 \\
\hline 8 & $202,206,218.51 .511$ & 0.000000 & 0.000000 \\
\hline 9 & $204.205,210.218 . M-201$ & 0.000000 & 0.000000 \\
\hline 10 & $207,208,209, M-202, S 2$ & 0.000000 & 0.000000 \\
\hline 11 & 211 & 0.000000 & 0.000000 \\
\hline 12 & $213,214,215$ & 0.000000 & 0.000000 \\
\hline \multicolumn{4}{|c|}{$\begin{array}{l}{ }^{\circ} M \text { ' indicates a mezzanine: ' } S \text { ' indicates stairs. } \\
{ }^{b} M \text { Measured from time } 0-t o-30 \mathrm{~min} \text {. }\end{array}$} \\
\hline
\end{tabular}

TABLE 16. TRANSPORT RESULTS FOR HVAC FAILURE ACCIDENT SCENARIO 2

\begin{tabular}{|c|c|c|c|}
\hline CONTROL VOLUME & ROOMS INCLUDED & $\frac{\text { PEAK QUANTITY }}{\text { OF PU }(k q)^{b}}$ & $\frac{\text { FINAL QUAANTITY }}{\text { OF Pu }(\mathrm{kg})^{\mathrm{b}}}$ \\
\hline 1 & none & 0.000000 & 0.000000 \\
\hline 2 & $104,109,110$ & 0.000000 & 0.000000 \\
\hline 3 & $105,106,107,203$ & 0.000000 & 0.000000 \\
\hline 4 & $108.117,118,119, M-102$ & 0.000052 & 0.000000 \\
\hline 5 & 111.112 .115 .116 & 0.000000 & 0.000000 \\
\hline 6 & 120 & 0.000000 & 0.000000 \\
\hline 7 & $121,122, \mathrm{M}-103,201,217,53$ & 0.000000 & 0.000000 \\
\hline 8 & $202,206.218, S 1 . S 11$ & 0.000000 & 0.000000 \\
\hline 9 & $204,205,210,218 . \mathrm{M}-201$ & 0.000000 & 0.000000 \\
\hline 10 & $207,208,209, \mathrm{M}-202, \mathrm{~S} 2$ & 0.000000 & 0.000000 \\
\hline 11 & 211 & 0.000000 & 0.000000 \\
\hline 12 & 213.214 .215 & 0.000000 & 0.000000 \\
\hline \multicolumn{4}{|c|}{$\begin{array}{l}{ }^{\circ} \mathrm{M} \text { ' indicates a mezzanine; ' } S \text { ' indicates stairs. } \\
{ }^{\circ} M \text { Measured from time } 0-10-30 \mathrm{~min} \text {. }\end{array}$} \\
\hline
\end{tabular}


TABLE 17. TRANSPORI RESULTS FOR HVAC FAILURE ACCIDENT SCENARIO 3

\begin{tabular}{|c|c|c|c|}
\hline CONTROL VOLUME & ROOMS INCLUDED & $\frac{\text { PEAK QUANTITY }}{\text { OF PU }(\mathrm{kg})^{\mathrm{b}}}$ & $\frac{\text { FINAL QUANTITY }}{\text { OF PU }(k g)^{b}}$ \\
\hline 1 & none & 0.000000 & 0.000000 \\
\hline 2 & 104.109 .110 & 0.000000 & 0.000000 \\
\hline 3 & $105,106,107,203$ & 0.000000 & 0.000000 \\
\hline 4 & $108,117,118,119, \mathrm{M}-102$ & 0.000066 & 0.000000 \\
\hline 5 & 111.112 .115 .116 & 0.000000 & 0.000000 \\
\hline 6 & 120 & 0.000000 & 0.000000 \\
\hline 7 & $121,122, \mathrm{M}-103,201,217, \mathrm{S3}$ & 0.000000 & 0.000000 \\
\hline 8 & $202.206,218,51,511$ & 0.000000 & 0.000000 \\
\hline 9 & $204,205,210,218, M-201$ & 0.000000 & 0.000000 \\
\hline 10 & $207.208 .209, M-202.52$ & 0.000000 & 0.000000 \\
\hline 11 & 211 & 0.000000 & 0.000000 \\
\hline 12 & $213,214.215$ & 0.000000 & 0.000000 \\
\hline \multicolumn{4}{|c|}{$\begin{array}{l}{ }^{a} M \text { ' indicates a mezzanine: ' } S \text { ' indicates stairs. } \\
{ }^{\circ} M \text { Measured from time } 0-10-30 \mathrm{~min} \text {. }\end{array}$} \\
\hline
\end{tabular}

TABLE 18. TRANSPORT RESULTS FOR HVAC FAILURE ACCIDENT SCENARIO 4

\begin{tabular}{|c|c|c|c|}
\hline CONTROL VOLUME & ROOMS INCLUDED & $\frac{\text { PEAK QUANTITY }}{\text { OF PU }(k g)^{b}}$ & $\begin{array}{l}\text { FINAL QUANTITY } \\
\text { OF PU }(\mathrm{kg})^{\mathrm{b}}\end{array}$ \\
\hline 1 & none & 0.000000 & 0.000000 \\
\hline 2 & 104.109 .110 & 0.000000 & 0.000000 \\
\hline 3 & $105,106,107,203$ & 0.000000 & 0.000000 \\
\hline 4 & $108,117,118,119, M-102$ & 0.000000 & 0.000000 \\
\hline 5 & $111,112.115,116$ & 0.000000 & 0.000000 \\
\hline 6 & 120 & 0.000000 & 0.000000 \\
\hline 7 & $121,122, \mathrm{M}-103,201,217, \mathrm{~S} 3$ & 0.000062 & 0.000000 \\
\hline 8 & $202,206,218, S 1 . \$ 11$ & 0.000000 & 0.000000 \\
\hline 9 & $204.205 .210 .218, M-201$ & 0.000000 & 0.000000 \\
\hline 10 & $207,208,209, M-202 . S 2$ & 0.000000 & 0.000000 \\
\hline 11 & 211 & 0.000000 & 0.000000 \\
\hline 12 & $213,214,215$ & 0.000000 & 0.000000 \\
\hline \multicolumn{4}{|c|}{$\begin{array}{l}{ }^{\circ} M \text { ' indicates a mezzanine; ' } S \text { ' indicates stairs. } \\
{ }^{\circ} M \text { Measured from time } 0-t o-30 \mathrm{~min} \text {. }\end{array}$} \\
\hline
\end{tabular}


TABLE 19. TRANSPORT RESULTS FOR HVAC FAILURE ACCIDENT SCENARIO 5

\begin{tabular}{|c|c|c|c|}
\hline CONTROL VOLUME & ROOMS INCLUDED & $\frac{\text { PEAK QUANTITY }}{\text { OF PU }(k, g)^{b}}$ & $\frac{\text { FINAL QUANTITY }}{\text { OF PU }(k g)^{b}}$ \\
\hline 1 & none & 0.000000 & 0.000000 \\
\hline 2 & 104.109 .110 & 0.000000 & 0.000000 \\
\hline 3 & 105.106 .107 .203 & 0.000000 & 0.000000 \\
\hline 4 & $108,117,118,119, \mathrm{M}-102$ & 0.000052 & 0.000000 \\
\hline 5 & $111,112.115 .116$ & 0.000000 & 0.000000 \\
\hline 6 & 120 & 0.000000 & 0.000000 \\
\hline 7 & $121,122 . \mathrm{M}-103,201,217, \mathrm{~s} 3$ & 0.000062 & 0.000000 \\
\hline 8 & $202,206,218,51,511$ & 0.000000 & 0.000000 \\
\hline 9 & $204,205,210,218, M-201$ & 0.000000 & 0.000000 \\
\hline 10 & $207.208 .209 . \mathrm{M}-202 . \mathrm{S} 2$ & 0.000000 & 0.000000 \\
\hline il & 211 & 0.000000 & 0.000000 \\
\hline 12 & 213.214 .215 & 0.000000 & 0.000000 \\
\hline \multicolumn{4}{|c|}{${ }^{\circ} M$ ' indicates a mezzanine; ' $S$ ' indicates stairs. } \\
\hline
\end{tabular}

TABLE 20. TRANSPORT RESULTS FOR HVAC FAILURE ACCIDENT SCENARIO 6

\begin{tabular}{|c|c|c|c|}
\hline CONTROL VOLUME & ROOMS INCLUDED & $\frac{\text { PEAK QUANTTYY }}{\text { OF PU }(\mathrm{kg})^{\mathrm{b}}}$ & $\frac{\text { FINAL QUANTITY }}{\text { OF PU }(\mathrm{kg})^{\mathrm{b}}}$ \\
\hline 1 & none & 0.000000 & 0,000000 \\
\hline 2 & 104.109 .110 & 0.000072 & 0.000001 \\
\hline 3 & $105,106,107,203$ & 0.000000 & 0.000000 \\
\hline 4 & $108,117.118,119, \mathrm{M}-102$ & 0.000000 & 0.000000 \\
\hline 5 & 111.112 .115 .116 & 0.000000 & 0.000000 \\
\hline 6 & 120 & 0.000000 & 0.000000 \\
\hline 7 & $121.122, \mathrm{M}-103,201,217 . \mathrm{S3}$ & 0.000000 & 0.000000 \\
\hline 8 & $202.206,218.51 .511$ & 0.000000 & 0.000000 \\
\hline 9 & $204,205.210,218 . M-201$ & 0.000000 & 0.000000 \\
\hline 10 & $207,208,209 . M-202.52$ & 0.000000 & 0.000000 \\
\hline 11 & 211 & 0.000000 & 0.000000 \\
\hline 12 & 213.214 .215 & 0.000000 & 0.000000 \\
\hline \multicolumn{4}{|c|}{$\begin{array}{l}{ }^{\circ} M \text { ' indicates a mezzanine: ' } S \text { ' indicates stairs. } \\
{ }^{b} M e a s u r e d \text { from time } 0-10-30 \mathrm{~min} \text {. }\end{array}$} \\
\hline
\end{tabular}




\subsection{SUMMARY OF RESULTS}

This analysls was characterlzed by four key subtasks: methodology development, systems analysls, event tree or accident scenario analysls, and consequence analysis. The methodology, described in Section 2.0, provided the structure around which the actual analyses were performed.

The first efforts in the systems analysis task Involved the regrouping of the rooms within the facllity into appropriate functlonal areas. These areas include waste feed, off-gas, llquld waste, solld waste, fines handlling and storage, grout mixing, filling of new drums, drum curing, and mechanical equipment (HVAC). The equipment in each of these nine areas was identifled and evaluated with respect to its location, elevation, and susceptlbillity (l.e., fragllity) to a DBE. The results from the systems analysis task were consolldated as fallure probabilitles (given a DBE) assoclated with each component evaluated within the facllity. These probabilltles were provided in Table 4, Section 3.0.

In the event tree analysis task, accident scenarios were postulated. Event tree models were developed for each area; and the fallure probabillties for the system analysls task were integrated into the appropriate model. Because the models represented included both llquid and aerosol releases, only the event tree models representing potentlal aerosol release were further quantifled (see Appendlx B). However, for possible clean-up implications from liquid releases, these models were also quantffled and Inclucled in Appendix B.

Quantification of the models of concern (I.e., aerosol) generated fallure probabillties for all sequences represented. Both success and fallure of HVAC were represented in the calculations (see Tables 5 and 6 , respectlvely). As shown in Tables 5 and 6 , the probabilitles for release with HVAC failure are $\leq 2.8754 \mathrm{E}-07$; and with HVAC success, $\leq 5.3837 \mathrm{E}-05$. Source term estimates were also calculated during this task (see Table 7). These estimates were incorporated as Initlal condltions in the consequence analysis computer model.

The environment within the PREPP facllity (e.g., pressures, temperatures, heat structures, and flow paths) was establlshed in a transport model. The estimated releases and fallures of each postulated accident sequence were incorporated as initial conditions of the facllity. The transport model calculated the consequences or effects of each postulated accldent sequence, for time 0 to $30 \mathrm{~min}$. 
In addlition to the 12 required scenarlos, two 'worst-case' models were also generated to reflect simultaneous fallures within all areas--again, with HVAC success and fallure. The results of these two models are provided as Flgures 18 and 19. As llustrated in these two figures, the maximum source term that could reach the environment is $2 \mathrm{ing}$ (see Figure 19). Because of this incredibly low amount, no offsite analysis was considered necessary. However, the data in these two flgures and Appendix $C$ provide valuable insight to potentlal onsite hazards that could be encountered with clean-up activitles. 


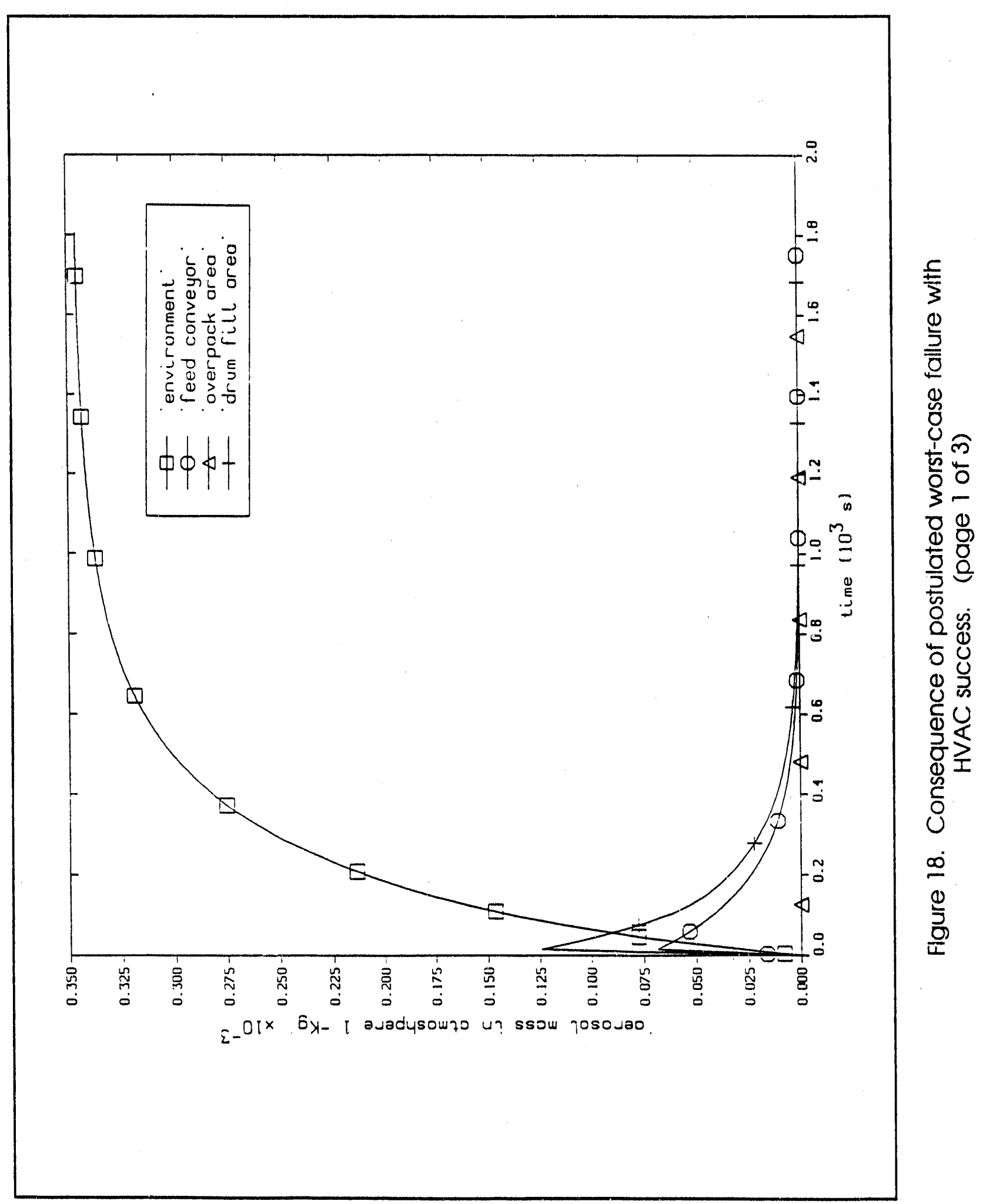




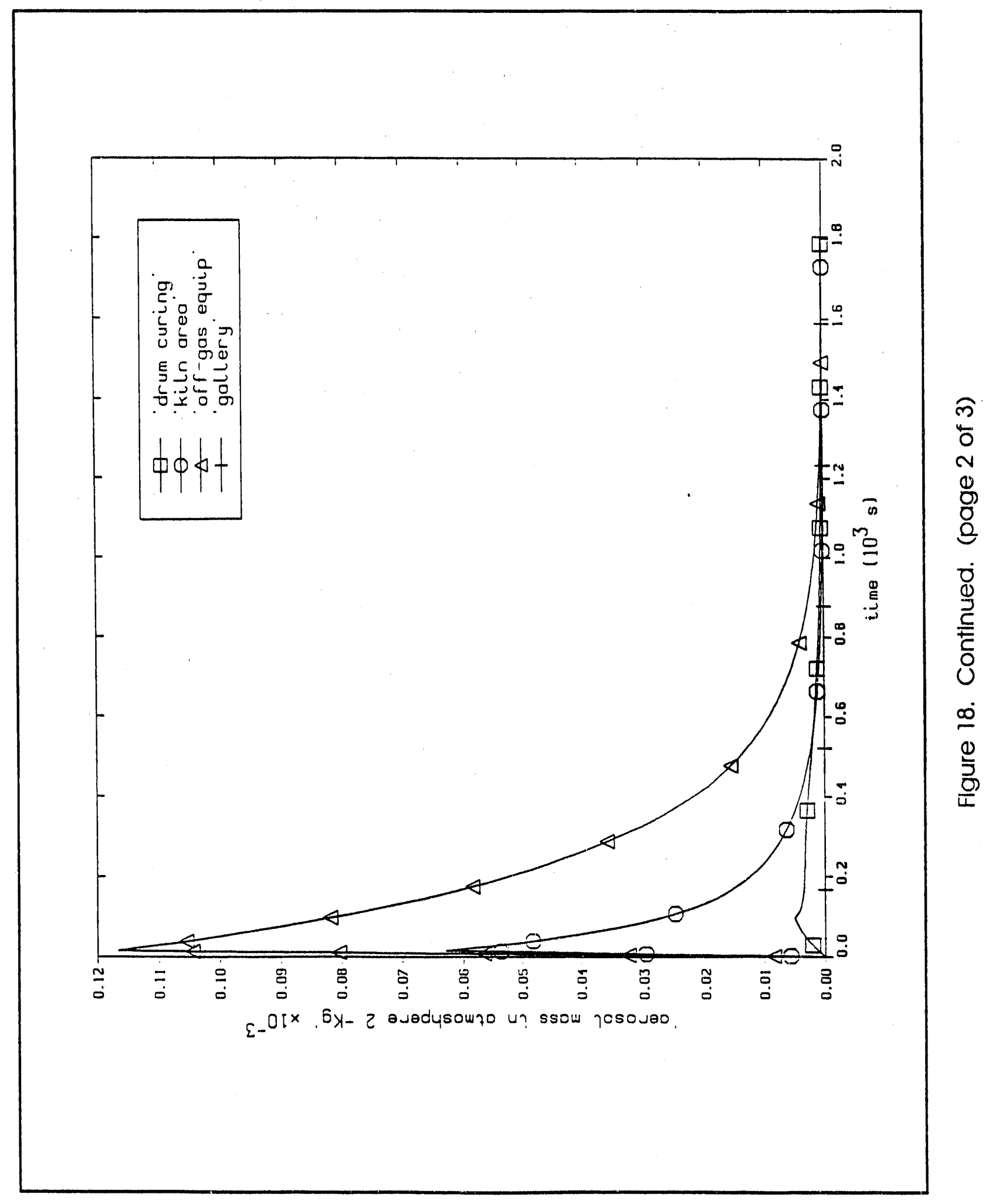









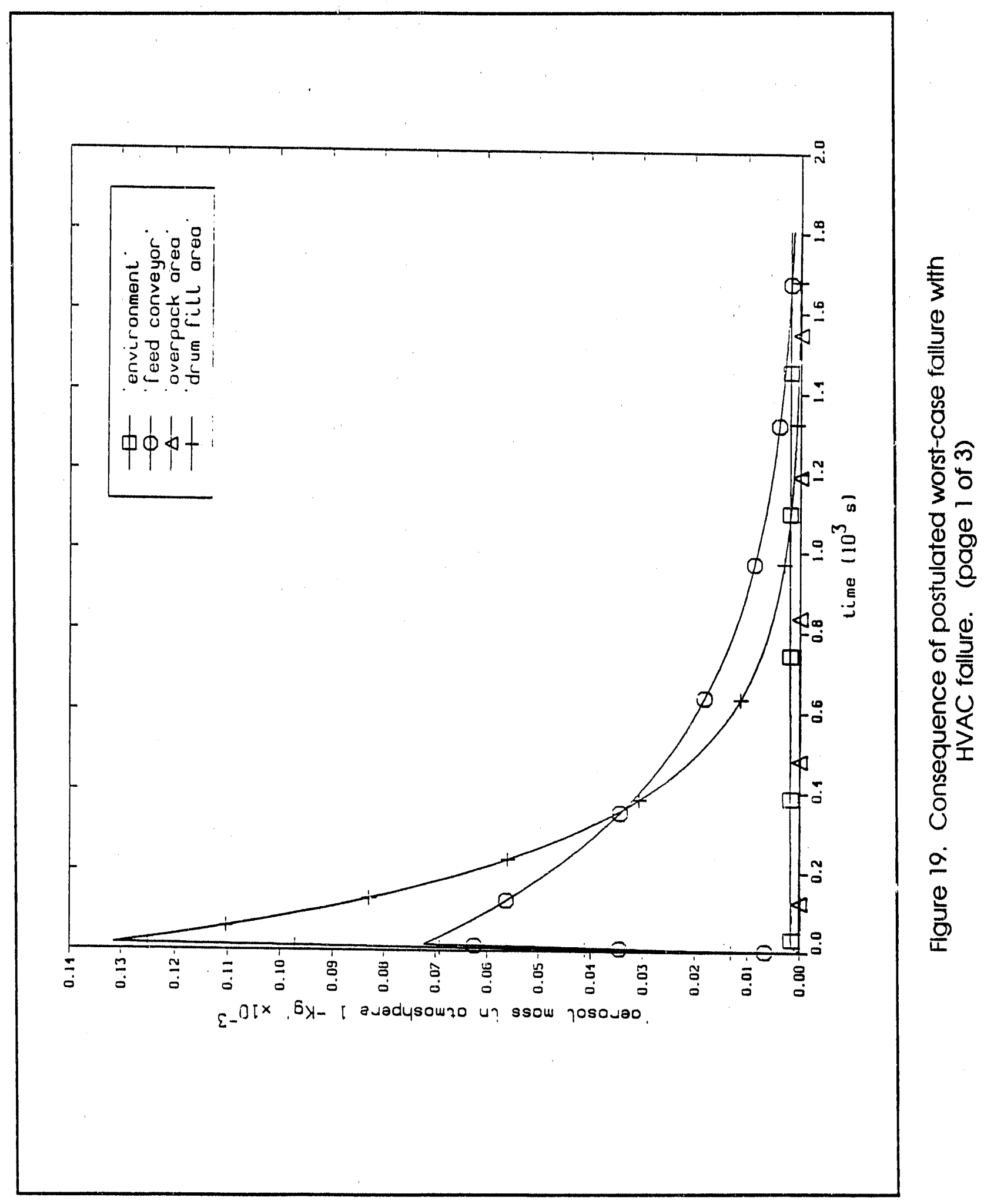









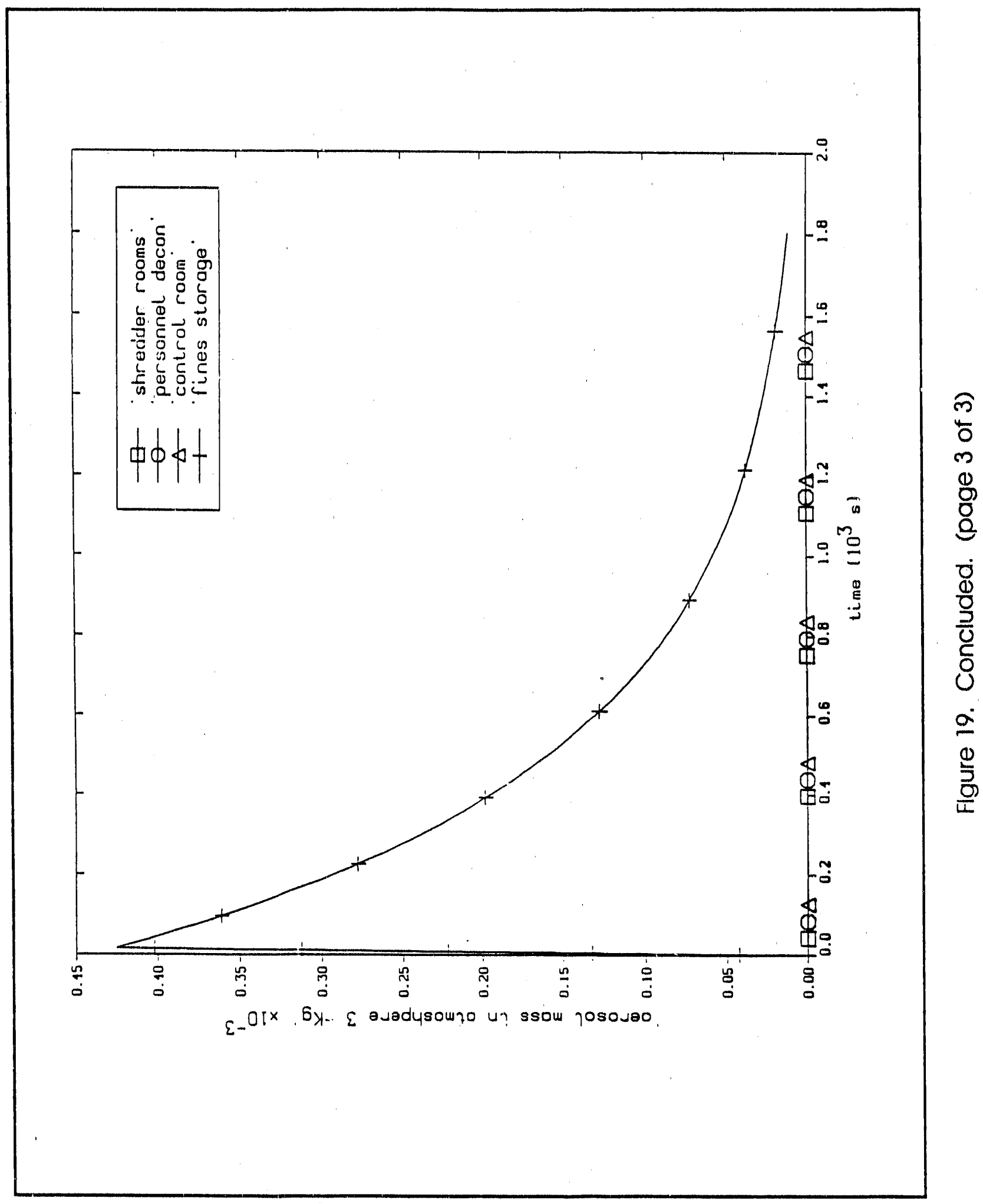




\subsection{CONCLUSIONS AND RECOMMENDATIONS}

The results of this entire analysis effort were thoroughly examined for apparent and/or subtle safety/risk Implications. One major assumption of this entire analysis effort was that the problem areas identifled in the structural analyses (Refs. 2 and 3) would be corrected (l.e., the bullding would remain intact). Therefore, results from both structural and equipment/faclilty analyses are Iricluded in the following conclusions and (where approprlate) recommendations:

(1) TAN 607 Structure-In the TAN 607 analysis, two areas were Identifieci as presenting potentlal risk (see Section 3.2.1). The scope of the current modiflcatlons will be expanded to include design and implementation of solutions to these two areas of primary concern. One of two solutions could satsfy the ecst wall concern: add addltional dlagonal bracing to the upper portions of the wall or remove the bridge crane, whichever is most cost-beneficlal. The solution to the concern with the truss In the north wall was the addltion of dlagonal bracing. Addlitional analysis of local areas of lesser concern will also be performed to ensure there will be no structural fallures of the TAN 607 bullying which would be detrimental to the integrity of the PREPP structure housed within the building.

(2) PREPP Structure-As mentioned above in Sectlo:1 1.0, the PREPP structural analysls indlcated that the PREPP bulliding structure meets current design criterla with the exception of end connections on the lower level dlagonal cross bracing between the support columns of the multllevel bullding walls. About seventy percent of these connections are directly accessible for rework and the rernaining locations may be rewoiked with relatively little structural modifications. Accordingly, the scope of the current modifications will be expanded to adequately strengthen the Indlcated cross bracling end connections to make the bullding si, cture comply wlith current DOE design criteria. 
(3) Confinernent (equipment structures)--The most common fallure Identifled for the equipmient within the PREPP facillty Involved the bolts and/or anchors supporting the equlpment. Therefore, it is recommended that adequate and proper anchoring of all equipment be verifled to ensuite structural ruggedness uf each of the confinements. 


\subsection{REFERENCES}

1. General Design Criteria, DOE Order 6430. 1A, Department of Energy, Washington, DC, Aprll 1989.

2. Singh, J. N., Seismic Evaluation of Two Bays of TAN-607, EDF-PREPP-408, EG\&G Idaho, Inc., Idaho Falls, ID, November 14, 1989.

3. Russell, M. J., Dynamlc Selsmic Analysis of the PREPP Bullaling, EDF-PREPP-400, EG\&G Idaho, Inc., Idaho Falls, ID, November 15, 1989.

4. Approach to the Quantification of Selsmic Margins in Nuclear Power Plants, NUREG/CR-4334, Lawrence Livermore National Laboratory, Livermore, CA, August 1985.

5. "Selsmlc and Dynamic Analysis Methods," PVP-Vol. 81, presented at The 1984 Pressure Vessels and Piping Conference and Exhibition in San Antonio, TX, American Soclety of Mechanlcal Engineers, New York, NY, 1984.

6. Shleh, L. C., et al., Simplifled Selsmlc Probabllistic Rlsk Assessment: Procedures and Limitations, NUREG/CR-4331, UCID-20468, Lawrence Livermore National Laboratory, Livermore, CA, August 19!5.

7. Prassinos, P. G., M. K. Ravindra, and J. B. Savy, Recommendatlons to the Nuclear Regulatory Commission on Trlal Guldellines for Selsmic Margin Revlews of Nuclear Power Plants, DRAF, NUREG/CR-4482, UCID-20579, Lawrence LIvermore Natlonal Laboratory, LIvermore, CA, Marci 1986.

9. Kimura, C. Y., and R. J. Budnitz, Evaluation of External Hazards to Nuclear Power Plants in the United States, NUREG/CR-5042, UCID-21223, Lawrence Livermore Natlonal Laboratory, Livermore, CA, December 1987.

10. Proceedings on Probabillistlc Methods in Selsmic Risk Assessment of Nuclear Power Plants, from Second CSNI Speclallst Meeting held In LIvermore, CA, USA, 16-18 May 1983, ESNI Report No. 76. Committee on the Safety of Nuclear Installations, Parls, France, 1983.

11. Budnitz, R. J., et al., An Approach to the Quantification of Selsmic Margins in Nuclear Power Plants, NUREG/CR-4334, UCID-20444, Lawrence Livermore National Laboratory, Livermore, CA, August 1985.

12. Newmark, N. M. and W. J. Hall, Development of Criterla for Selsmic Review of Selected Nuclear Power Plants, NUREG/CR-0098, N. M. Newmark Consulting Engineering Services, Urbana, IL, May 1978. 
13. Coats, D. W., Recommended Revisions to Nuclear Regulatory Commission Selsmlc Design Criterla, NUREG/CR-1161, Lawrence Livermore Laboratory, Livermore, CA, May 1980.

14. A Methodology for Assessment of Nuclear Power Plant Selsmic Margin, EPRI-NP-6041, Electric Power Research Instltute, Palo Alto, CA, October 1988.

15. Garrick, B. John, Karl N. Fleming, and Alfred Torrl, Seabrook Station Probabllistlc Safety Assessment Technical Summary Report, PLG-0365, Plckard, Lowe and Garrick, Inc., Newport Beach, CA, June 1984.

16. Campbell, R. D., et al., Compllation of Fraglllty Information from Avallable Probabillstlc Rlsk Assessments, UCID-20571, Lawrence Livermore National Laboratory, CA, September 1985.

17. Kennedy, R. P., et al., Subsystem Fragllity, Selsmic Safety Margins Research Program, Phase !, NUREG/CR-2405, UCRL-15407, Lawrence Livermore National Laboratory, Livermore, CA, February 1982.

18. Cover, L. E., et al., Handbook of Nuclear Power Plant Selsmic Fragilltles, Selsmic Safety Margins Research Program, NUREG/CR-3558, UCRL-53455, Lawrence Livermore National Laboratory, Livermore, CA, June 1985.

19. Bandyopadhyay, K. K., et al., Seismic Fragllity of Nuclear Power Plant Components, Phase II, NUREG/CR-3549, Vol. 2, Brookhaven National Laboratory, Long Island, NY, December 1987.

20. Smith, C. B. and K. L. Merz, Generlc Selsmic Ruggedness of Power Plant Equlpment, NP-5223, ANCO Engineers, Inc., Culver Clty, CA, May 1987.

21. Probabillstic Rlsk Assessment (PRA) Reference Document, NUREG-1050, U.S. Nuclear Regulatory Commlssion, Washington, D.C., September 1984.

22. PRA Procedures Gulde, NUREG/CR-2300, Vols. 1 and 2, U. S. Nuclear Regulatory Commission, Washington, D.C.. January 1983.

23. Budnitz, Robert J., "Selsmlc PRA: Recent Developments In Methodology and Applications," Future Resources Assoclates, Inc., Berkeley, CA, 1989.

24. Shibata, H. and K. Abe, "Discussion of Seismlc Risk Analysis issues in Japan Ralsed by Recent Research at Jaeri," University of Tokyo and Japan Atomic Energy Research Instltute, Japan, 1989.

25. Chen, J. T. and W. D. Beckher, "Severe Accident Pollcy Implementation External Events," U.S. Nuclear Regulatory Commission, Washington, D.C., 1989.

26. Wells. J. E., Rellabllity Data Required for a Selsmic Risk Assessment, Lawrence Livermore Natlonal Laboratory, Livermore, CA. 
27. Singh, Jag N., Selsmic Evaluation of Process Experimental Pllot Plant, EG\&G Idaho, Inc., Idaho Falls, ID, January 1989.

28. Prellminary PREPP Facillty Probabillstic Safety (Risk) Assessment, Phase I Report, Rev, O, EG\&G Idaho, Inc., Idaho Falls, ID, January 1989.

29. "PREPP Phase I PRA Review Presentation," EG\&G Idaho, Inc., Idaho Falls, ID, April 18, 1988.

30. Wilkins, D. E., Crlticallty Control Plan for the Process Experimental Pillot Plant (PREPP), Draft, EG\&G Idaho, Inc., Idaho Falls, ID, January 15, 1986.

31. PREPP Operating Manual, Vo', I, EG\&G Idaho, Inc., Idaho Falls, ID, 1988.

32. PREPP Operating Manual, Vol. II, EG\&G Idaho, Inc., Idaho Falls, ID, 1988.

33. PREPP Operating Manual, Vol, III, EG\&G Idaho, Inc., Idaho Falls, ID, 1988.

34 PREPP Operating Manual, Vol. IV, EG\&G Idaho, Inc., Idaho Falls, ID, 1988.

35. Woods, W. D., Correspondence re: Job 5943--Process Experimental Pllot Plant Off-Gas Piping Analysls, HALS-52-84, The Ralph M. Parsons Company, Pasadena, CA, May 10, 1984.

36. Morton, D. K., PREPP Off-Gas System Stress Reanalysis, EDF-PREPP-149, EG\&G Idaho, Inc., ldaho Falls, ID, December 20, 1984.

37. Miller, G. K., Siress Effects of Misallanment of the Quencher Vessel, EDF-PREPP-230, EG\&G Idaho, Inc., Idaho Falls, ID, December 1, 1986.

38. Rahl, R. G., Feed System Stress Analysis on Lexan Window, EDF-PREPP-155, EG\&G Idaho, Inc., Idaho Falls, ID, January 17, 1985.

39. Uldrich, E. D., Stress Analysls of PREPP incinerator Discharge Conveyor, EDF-PREPP-1 16, EG\&G Idaho, Inc., Idaho Falls, ID, September 11, 1984.

40. Gale, L., Report on Test Results for ATP'S 19006 (oolv), 19007 (PVC), 19008 (mixtures), 19015 (fiberglass \& wood), and 19016 (paper), EDF-PREPP-348, EG\&G Idaho, Inc., Idaho Falls, ID, January 10, 1989.

41. Langford, J. E., "Revlew of Feed System Operating System - JEL-9-89," Interofflce Correspondence, EG\&G ldaho, Inc., Idaho Falls, ID, November 13, 1989.

42. Gale, L., Evaluation of the Off-Gas System Capacity, EDF-PREPP-383, EG\&G Idaho, Inc., Idaho Falls, ID, August 30, 1989. 
43. Stermer, D. and L. Gale, Report Documenting Results and Conclusions from the Quencher Droplet Test - ATP9312, EDF-PREPP-374, EG\&G Idaho, Idaho Falls, ID, August 30, 1989.

44. Stermer, D. L., Report on the Off-Gas System Components Performance Test Results Durlog ATP-9307, ATP-9310, ATP-9311, ATP-19013, and ATP-19018, EDF-PRE 349, EG\&G ldaho, Inc., Idaho Falls, ID, Aprll 20, 1989.

45. Franz, W. A. "Process Experimental Pllot Plant (PREPP) NESHAP Appllcation WAF-71-89," Correspondence, EG\&G Idaho, Inc., idaho Falls, ID, September 28, 1989.

46. Kennedy, Robert P., et al., Deslgn and Evaluation Guldeilnes for Department of Energy Facllitles Subjected to Natural Phenomena Hazards, UCRL-15910, Draft, Lawrence Livermore Natlonal Laboratory, Livermore, CA, Aprll 1988.

47. Miller, G. V., Floor Acceleration Response Spectra Generation for the PREPP Building, EDF-PREPP-406, EG\&G Idaho, Inc., Idaho Falls, ID, January 15, 1990.

48. 49 CFR, Ch. $1,178.109-11,10-1-86$.

49. Meeting with L. Eale, J. Langford, L. Ball, B. Meale, V. Lucero for determining assumptions, equipment characterization, and other deterministic information necessary for completing the analysis, held on 19 December 1989.

50. Notegram from L. J. Ball to Vickle Lucero, re: "Informatlon Requested for PREPP seismic Consequence Analysis," December 14, 1989.

51. Gale, L., Informal written communication re: "Reasonable Estimate of Pu Content of the Scrub Solution," December 21, 1989.

52. Gale, L., Informai communication, December 1989.

53. Ball, L., Informal communication, January 15, 1990.

54. RISKMAN, PRA Workstation Software, developed by PIckard, Lowe, and Garrick, Inc., October 1989.

55. Draft Environmental Assessment for The Process Experlmental Pllot Plant Idaho National Engineering Laboratory, Predecisional (DOE/EA), U.S. Department of Energy, Idaho Falls, ID, February 1990.

56. Wenzel, D. R., Radlologlcal Safety Analysls Computer (RSAC) Program, Version 4.0, 1990.

57. MELCOR, computer modellng code, developed by Sandia National Laboratorles, Albuquerque, NM, 1988. 
APPENDIX A COMPONENT FRAGILITY CURVES 




Figure A-1. Feed conveyor fraglilty curve.

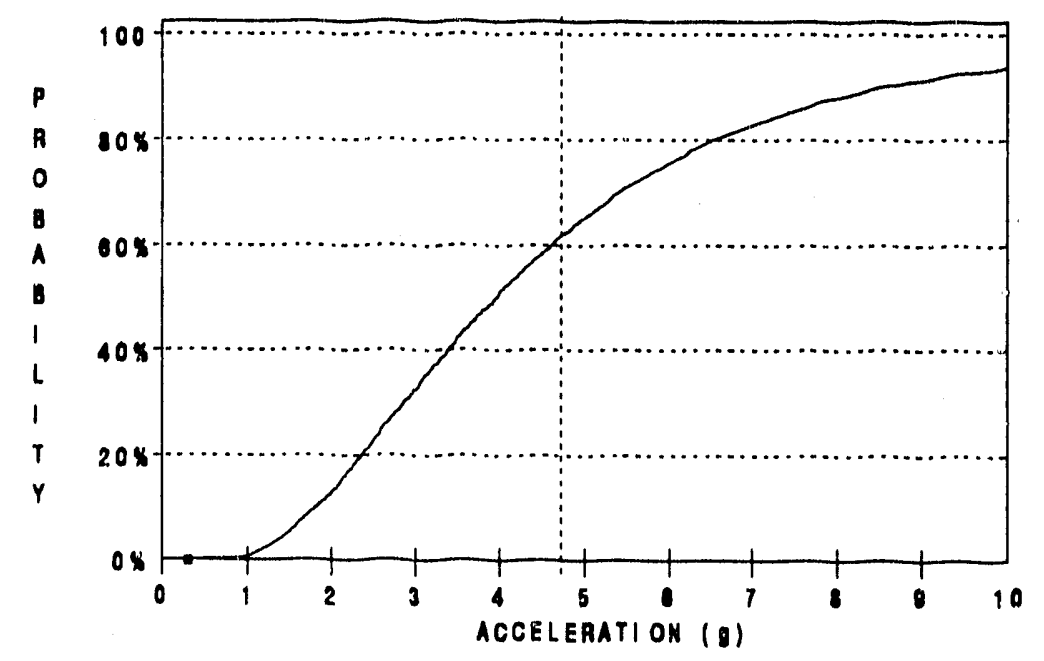

Flgure A-2. Kiln fragllity curve. 


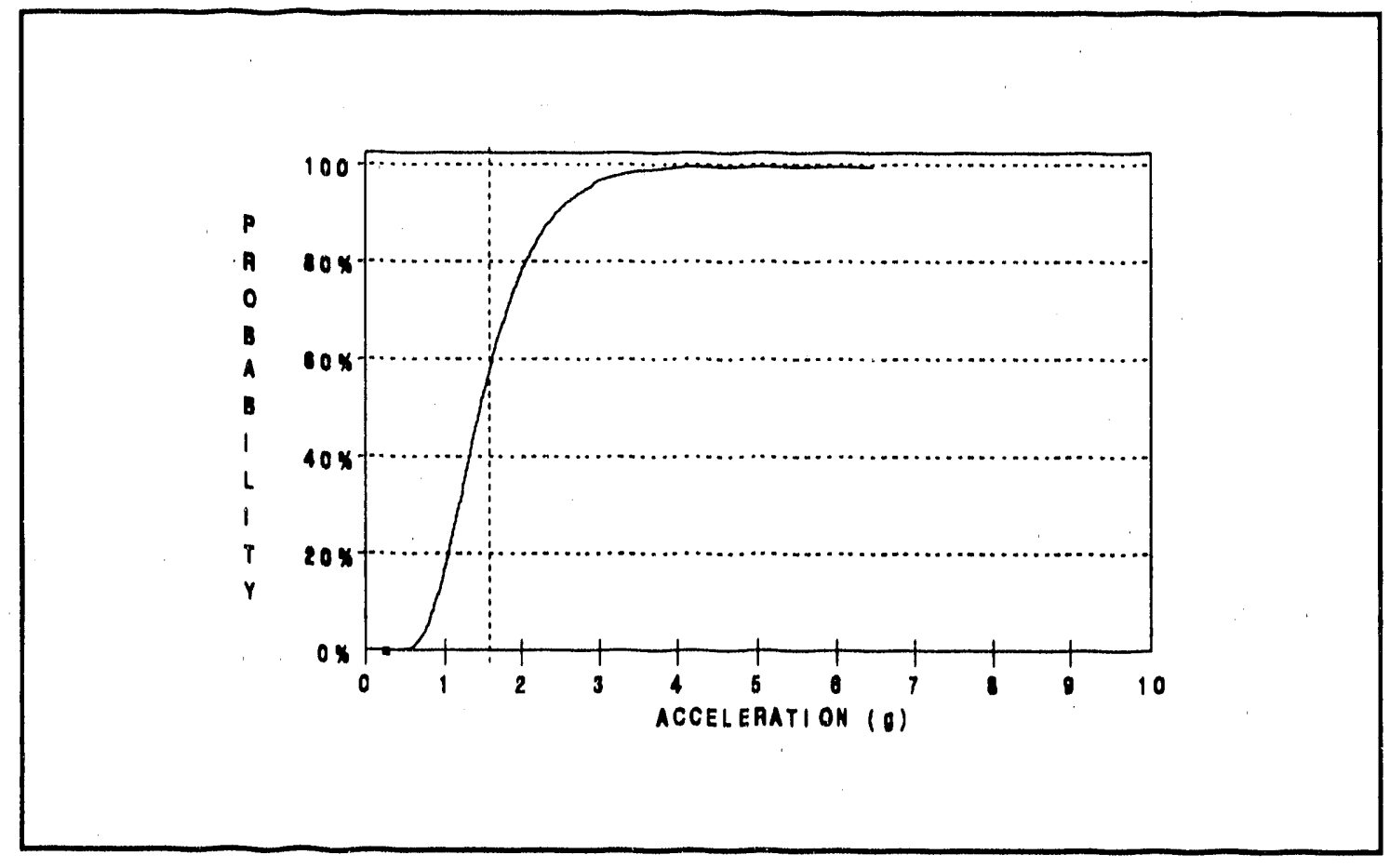

Figure A-3. Off-gas vessels fragillty curve.

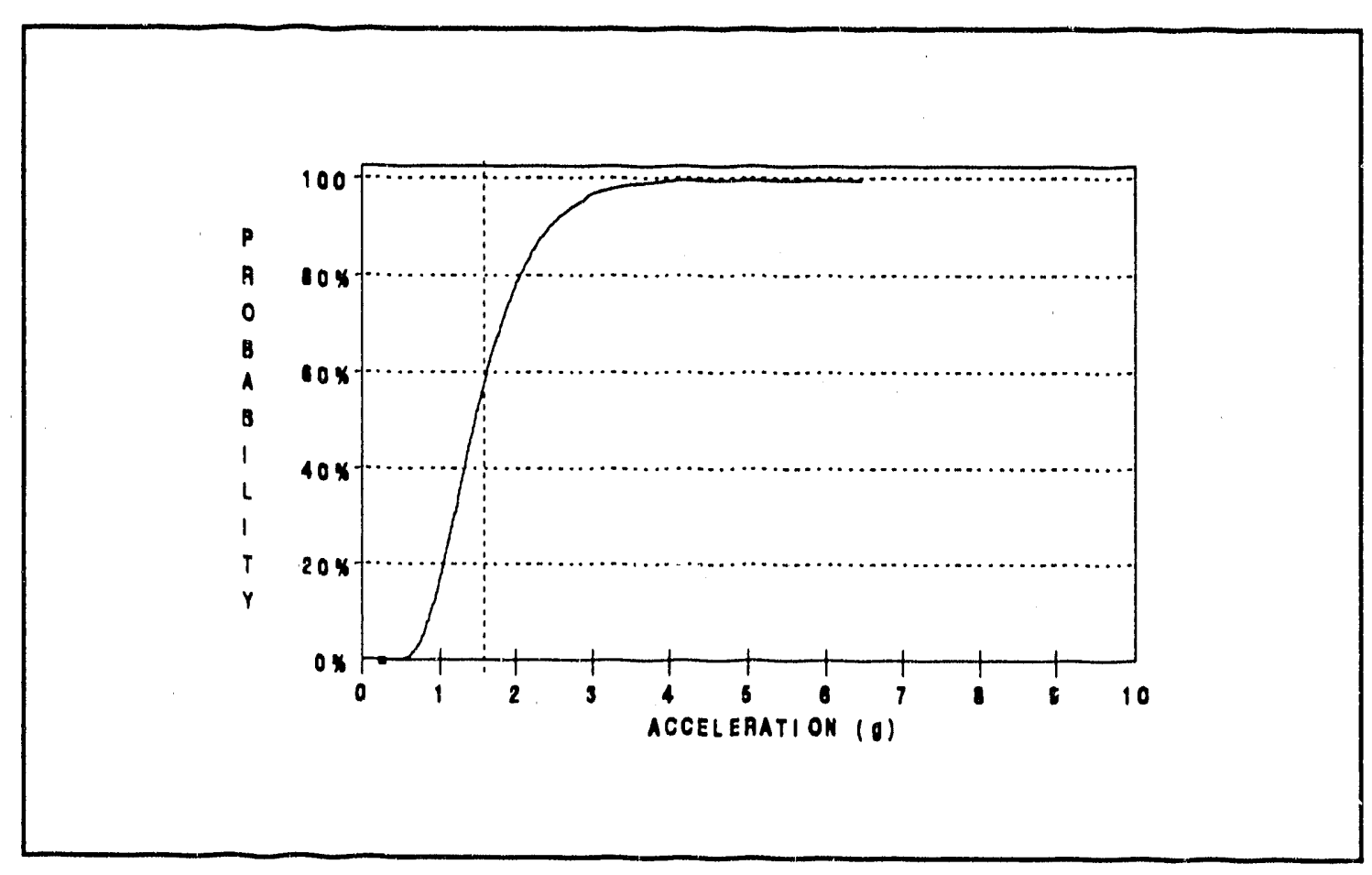

Figure A-4. Surge Recycle Tank fragillty cunve. 


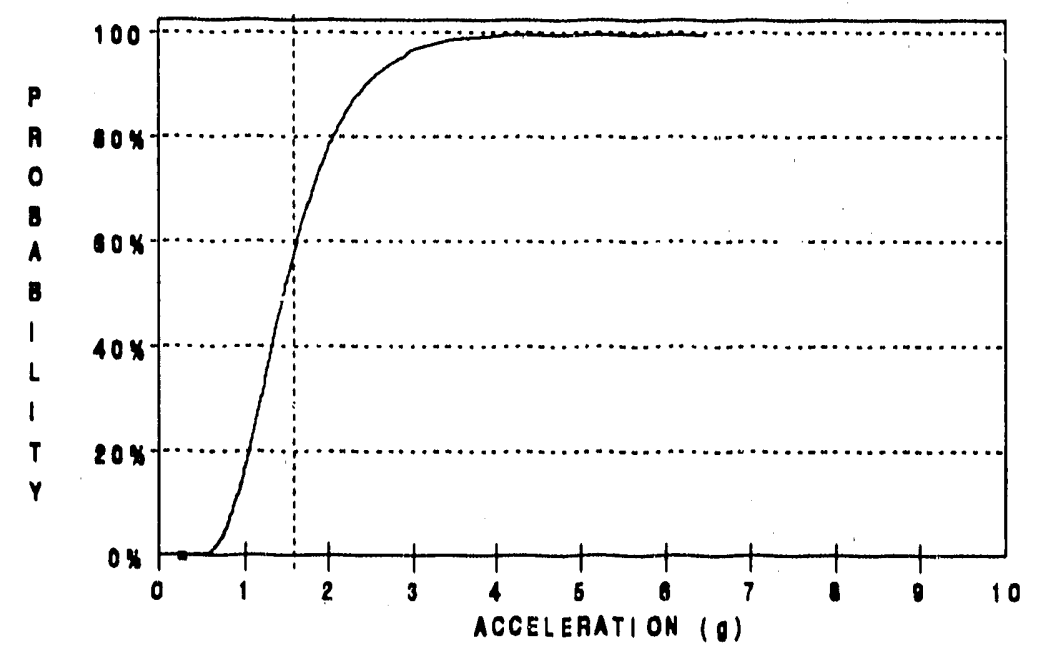

Flgure A-5. Sludge tank fragillty curve.



Figure A-6. Sludge tank pump fragillty curve. 


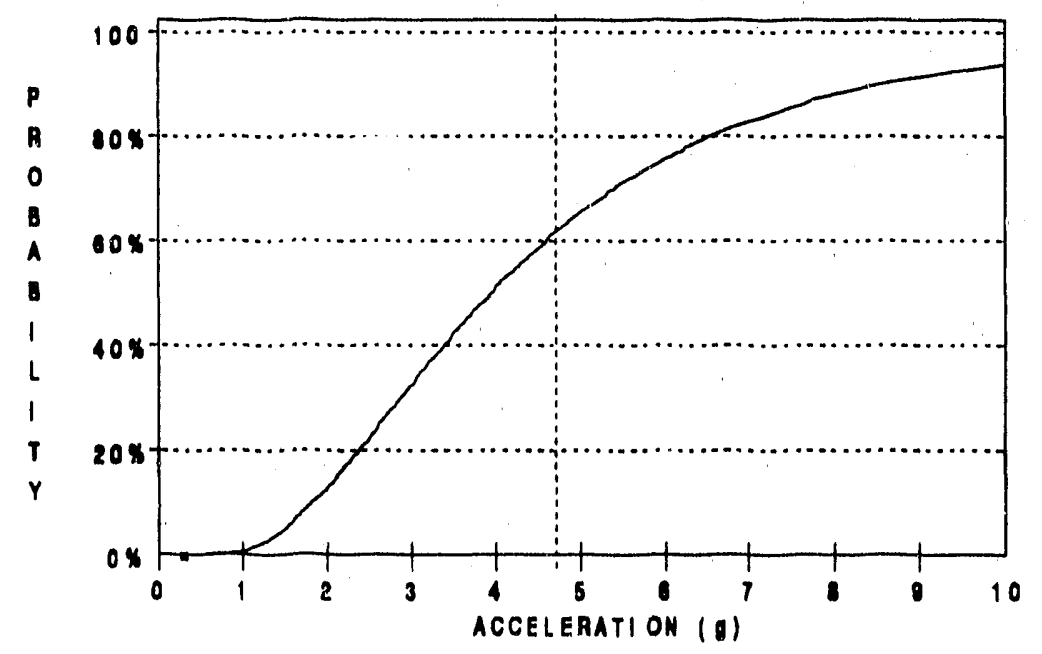

Flgure A-7. Surge recycle and emergency drain tanks fragillity curve.

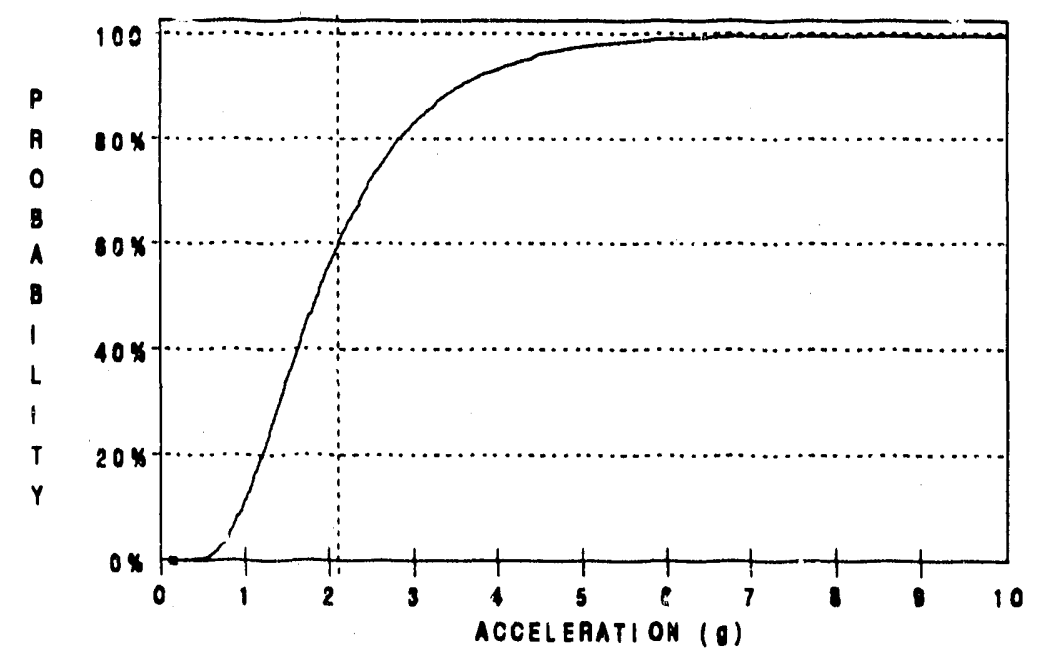

Flgure A-8. Discharge conveyor fraglllty curve. 


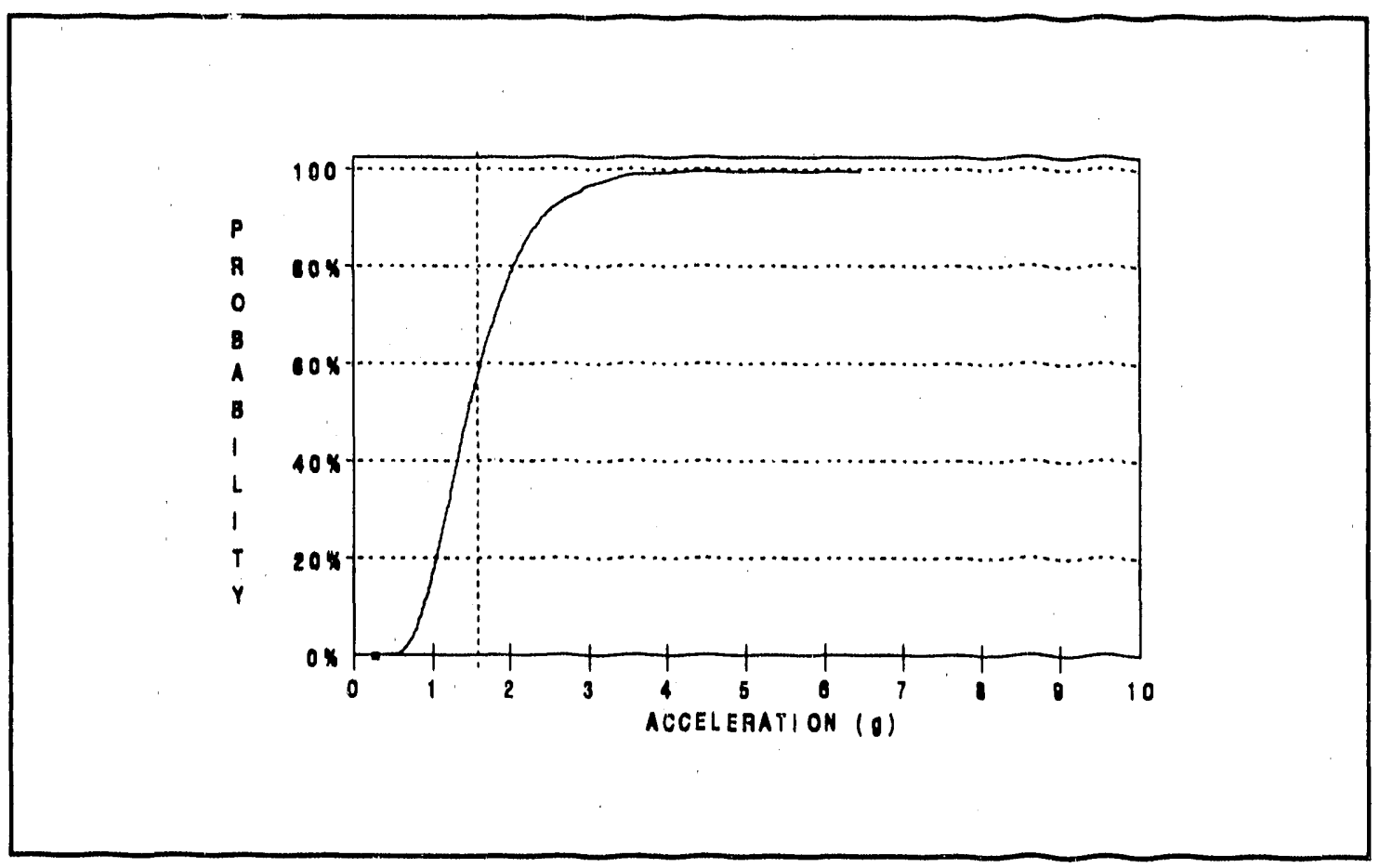

Flgure A-9. Trommel hopper fraglllty curve.

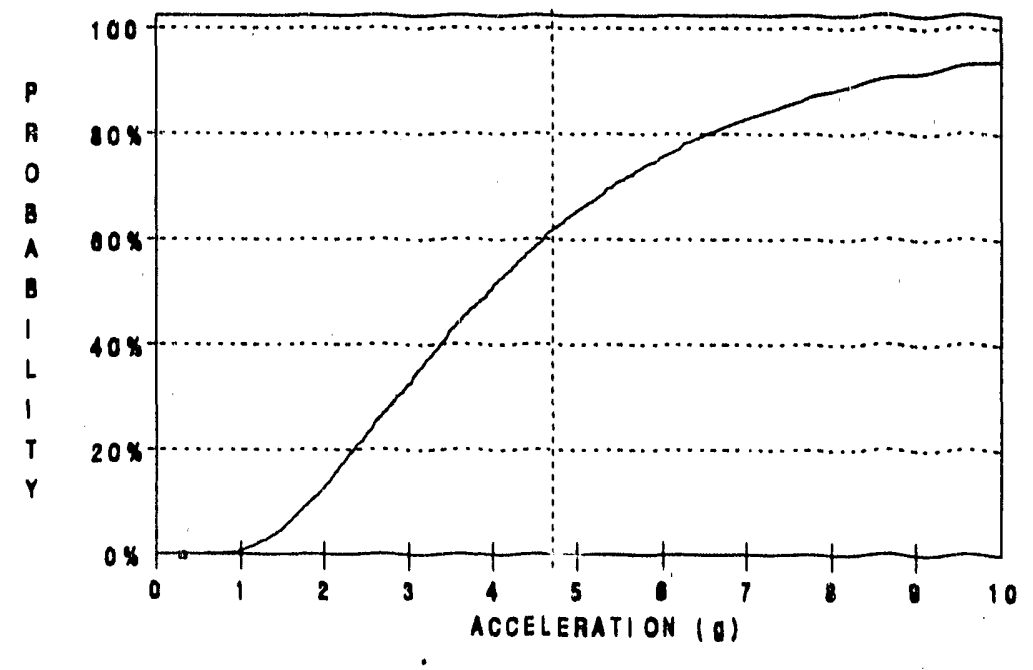

Flgure A-10. Fines hoppers and blenders fraglity curve. 


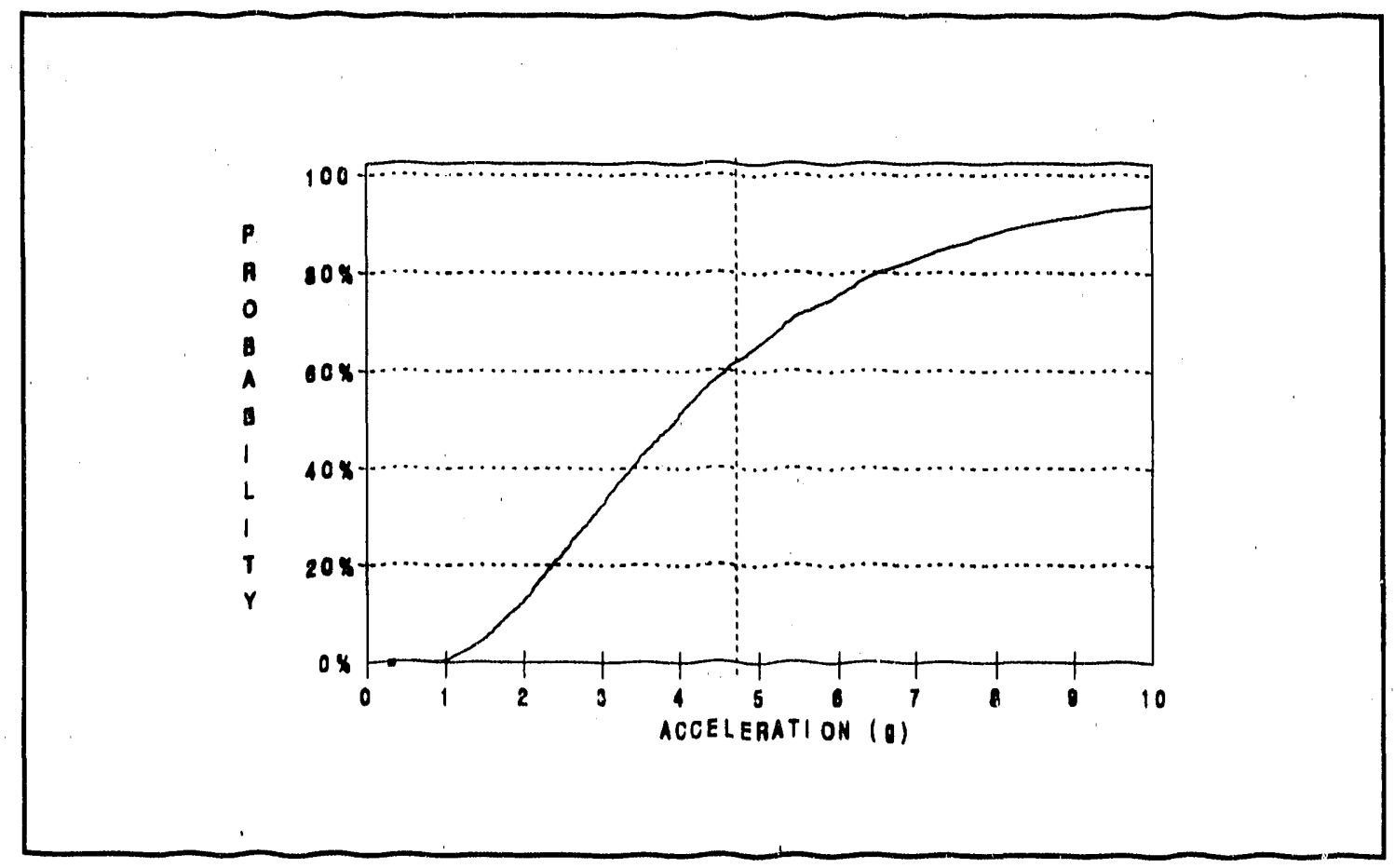

Figure A-11. Grout mixer fragllity curve. 
APPENDIX B

AREA EVENT TREES 


\begin{tabular}{|c|c|c|c|}
\hline $\begin{array}{l}\text { SEISMIC } \\
\text { INITIATING } \\
\text { EVENT }\end{array}$ & $\begin{array}{l}\text { FEED } \\
\text { CDNVEYDR } \\
\text { ENCLDSURE }\end{array}$ & $\begin{array}{l}\text { KILN \& } \\
\text { SECDNDARY } \\
\text { CDMBUSTIUN } \\
\text { CHAMBER }\end{array}$ & $\begin{array}{l}\text { SEQUENCE } \\
\text { PRDBABILITY }\end{array}$ \\
\hline IE & $F C$ & $K L$ & \\
\hline \multirow{7}{*}{$1.0 E-3$} & \multirow[b]{2}{*}{$9.9647 E-1$} & $9.9976 E-1$ & \multirow{2}{*}{$9.9623 E-4$} \\
\hline & & & \\
\hline & \multirow[b]{4}{*}{$3.53 E-3$} & $2.4 E-4$ & \multirow[t]{2}{*}{$2.3915 E-7$} \\
\hline & & & \\
\hline & & $9.9976 E-1$ & \multirow{2}{*}{$3.5292 E-6$} \\
\hline & & \multirow{2}{*}{$2.4 E-4$} & \\
\hline & & & $8.472 E-10$ \\
\hline
\end{tabular}

Figure B-1. Area 1 (feed) event tree. 


\begin{tabular}{|c|c|c|c|}
\hline $\begin{array}{l}\text { SEISMIC } \\
\text { INITIATING } \\
\text { EVENT }\end{array}$ & $\begin{array}{l}\text { WET } \\
\text { QUENCHER }\end{array}$ & $\begin{array}{l}\text { DFF-GAS } \\
\text { VESSELS }\end{array}$ & $\begin{array}{l}\text { SEQUENCE } \\
\text { PRDBABILITY }\end{array}$ \\
\hline IE & $W Q$ & QG & \\
\hline \multirow{4}{*}{$1.0 E-3$} & $9.3844 E-1$ & \multirow[b]{2}{*}{$2.33 E-4$} & $9.3822 E-4$ \\
\hline & & & $2.1866 E-7$ \\
\hline & $6.156 E-2$ & $9.9977 E-1$ & $6.1546 E-5$ \\
\hline & & $2.33 E-4$ & $1.4343 E-8$ \\
\hline
\end{tabular}

Flgure B-2. Area 2 (off-gas) event tree. 


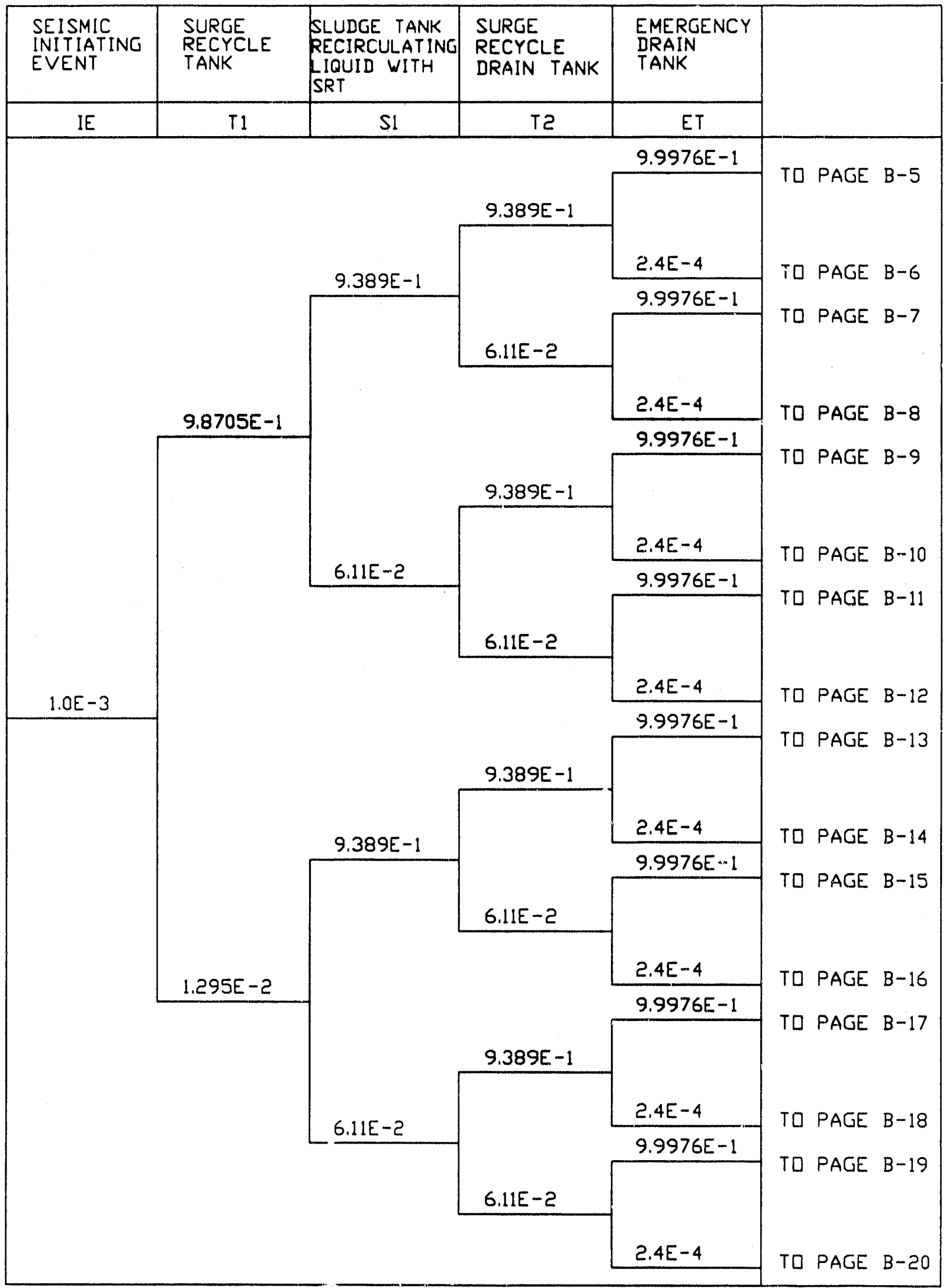

Figure B-3. Area 3 (liquid) event tree. (page 1 of 17) 


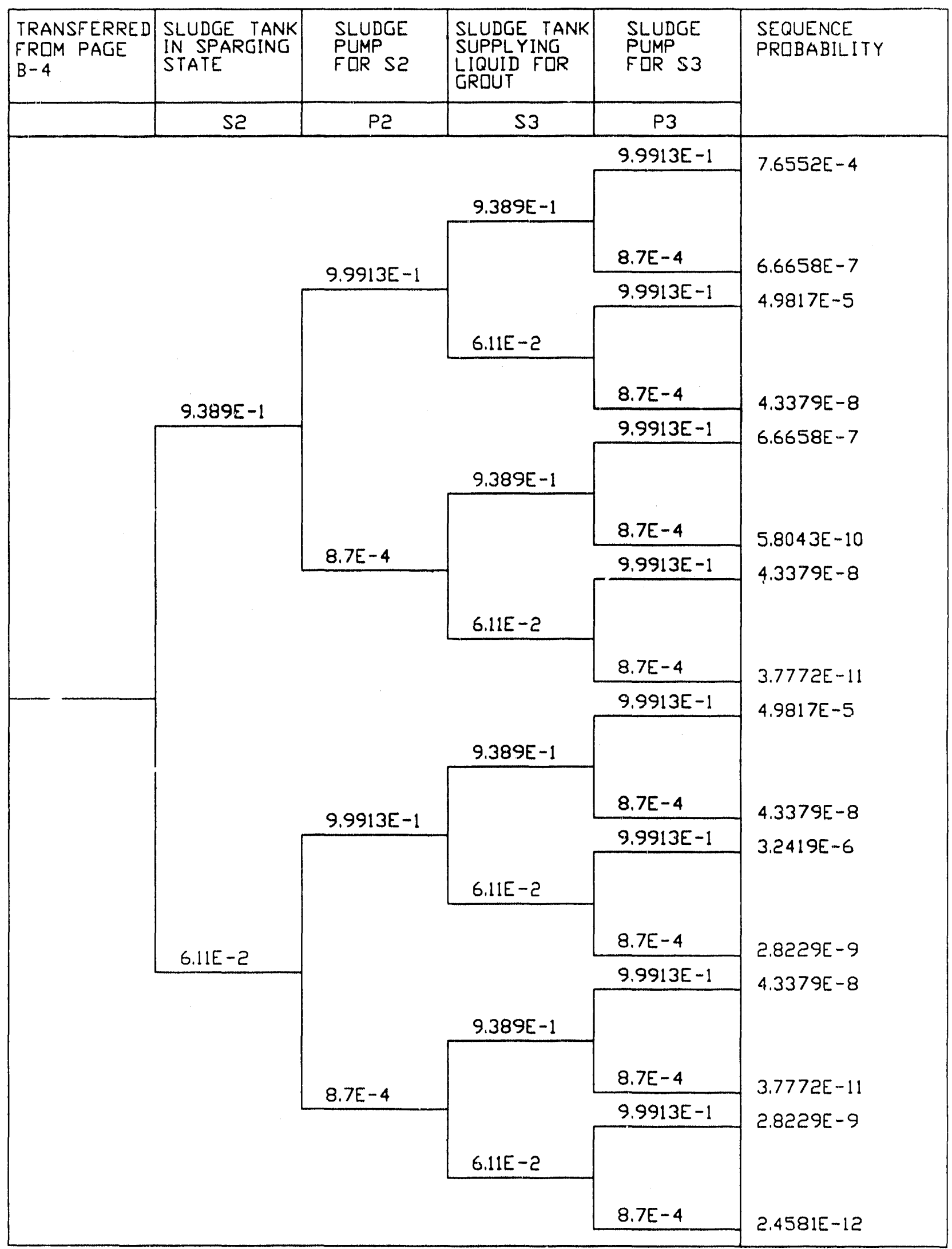

Figure B-3. Continued. (page 2 of 17) 


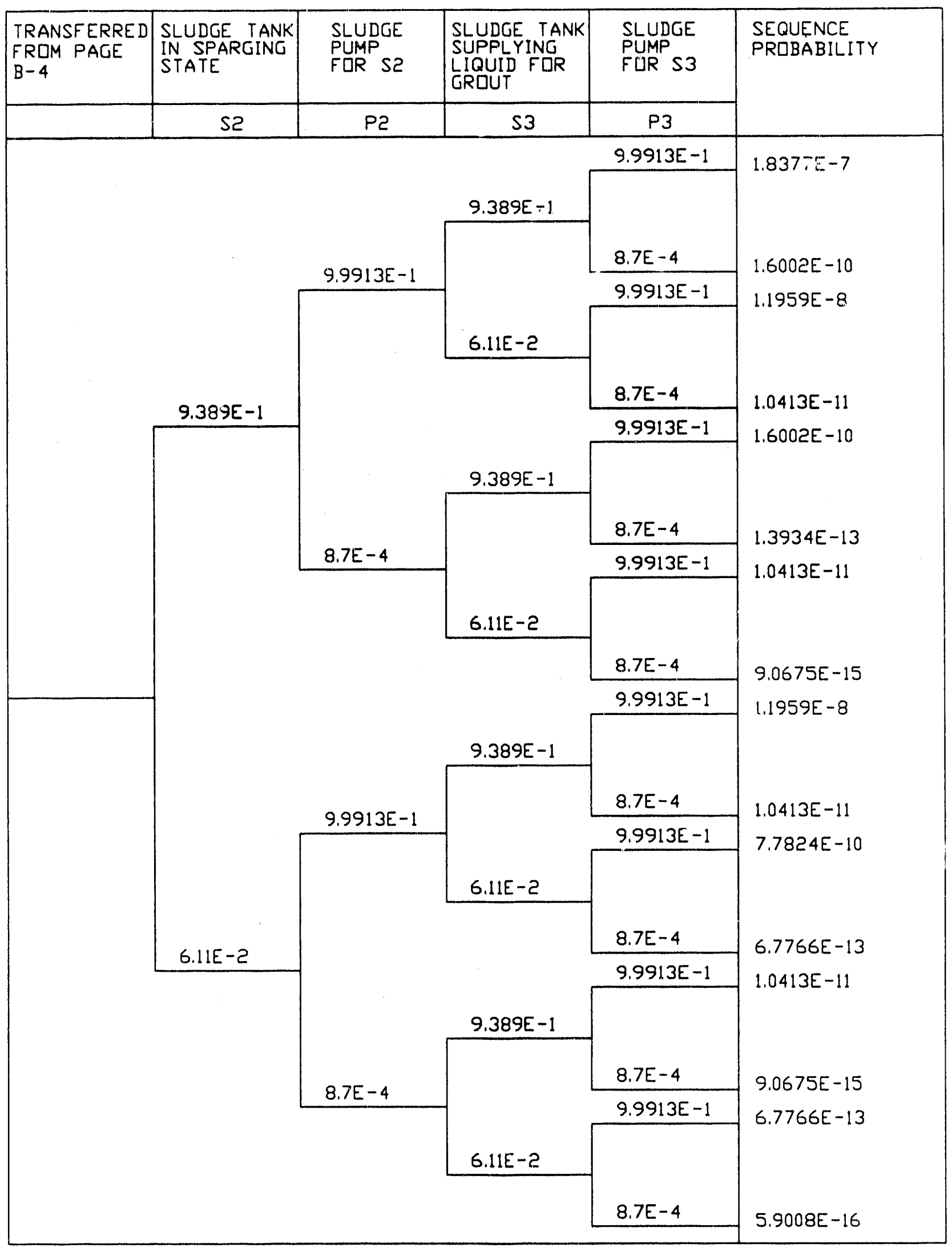

Figure B-3. Continued. (page 3 of 17) 


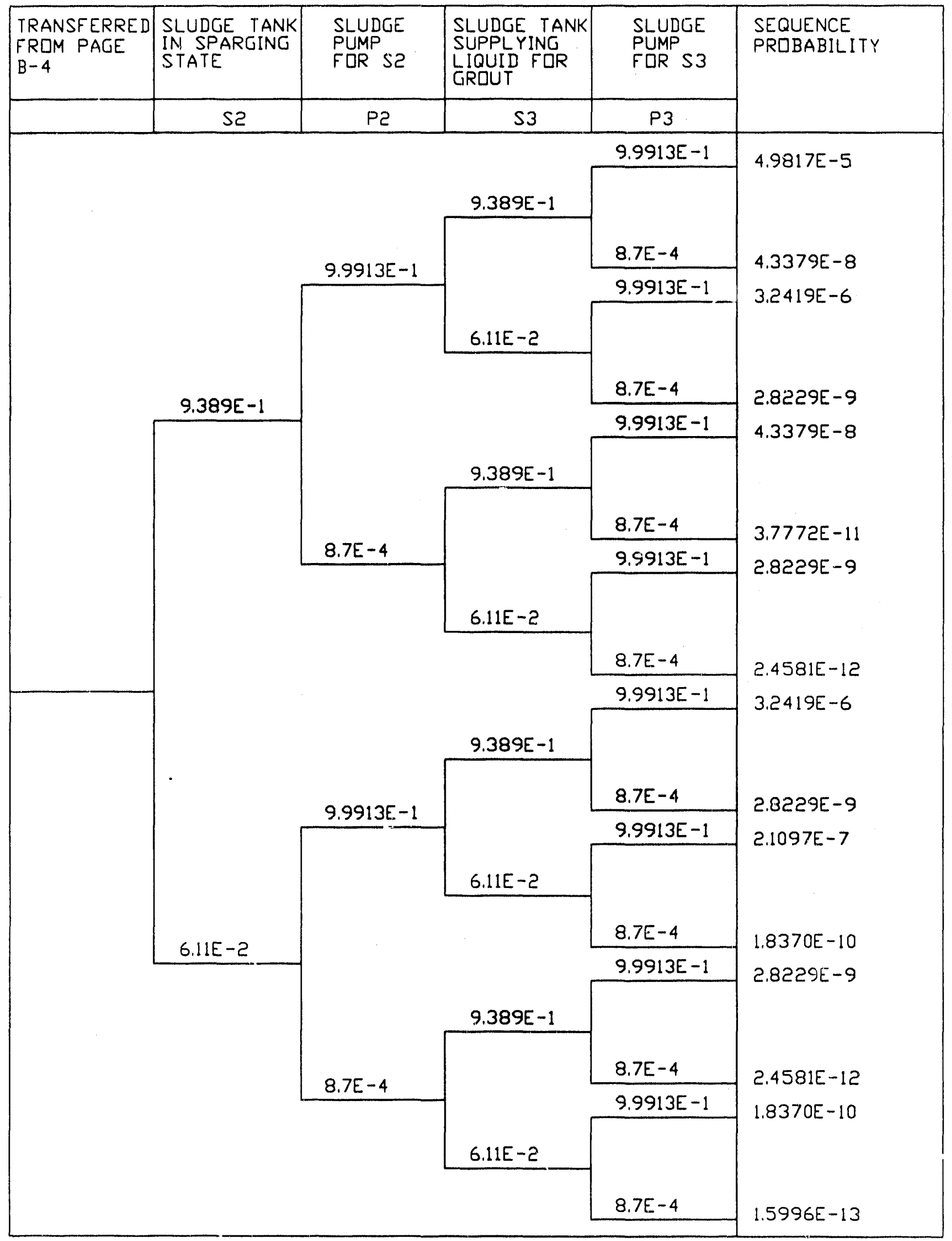

Figure B-3. Continued. (page 4 of 17) 




Figure B-3. Continued. (page 5 of 17) 


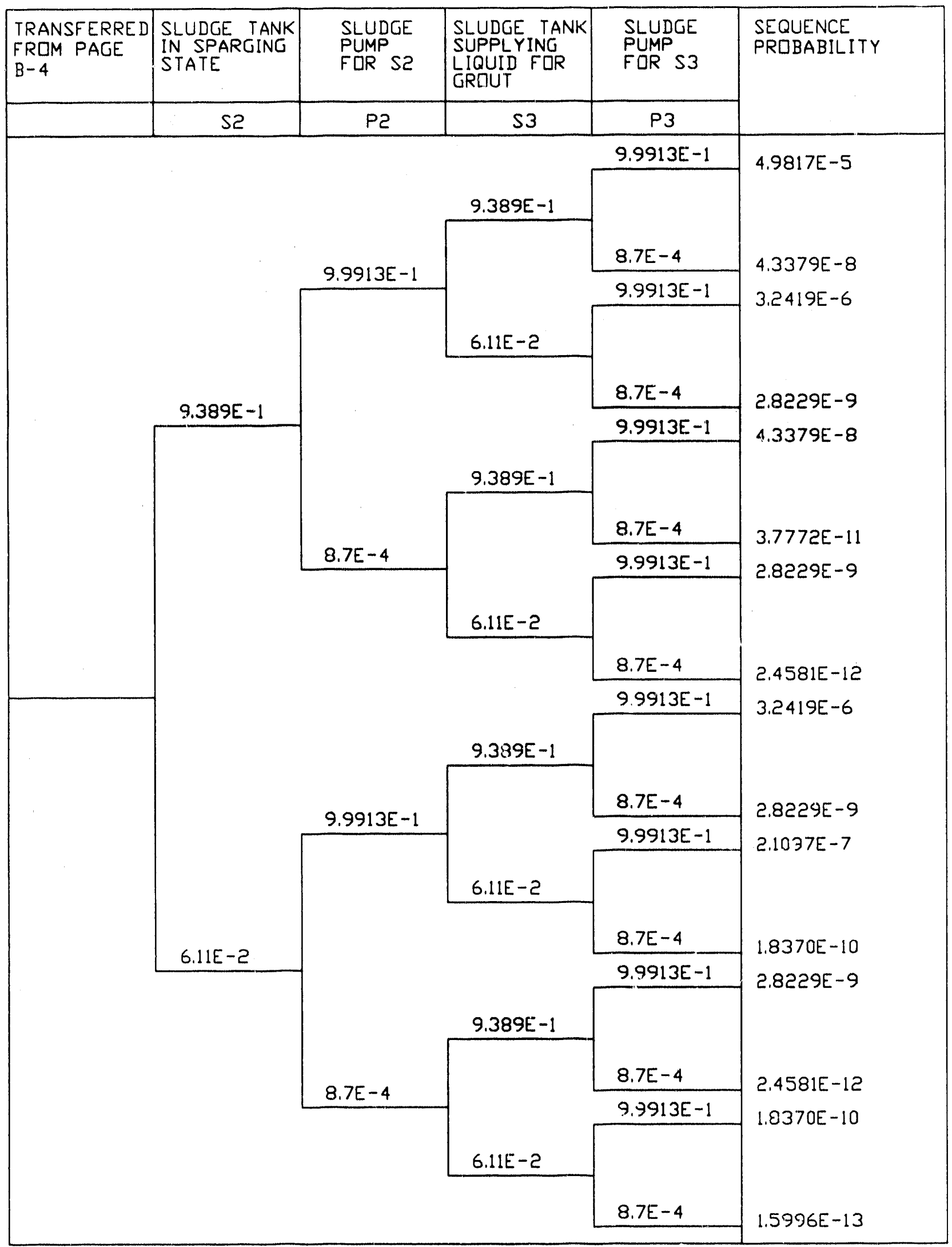

Figure B-3. Continued. (page 6 of 17) 


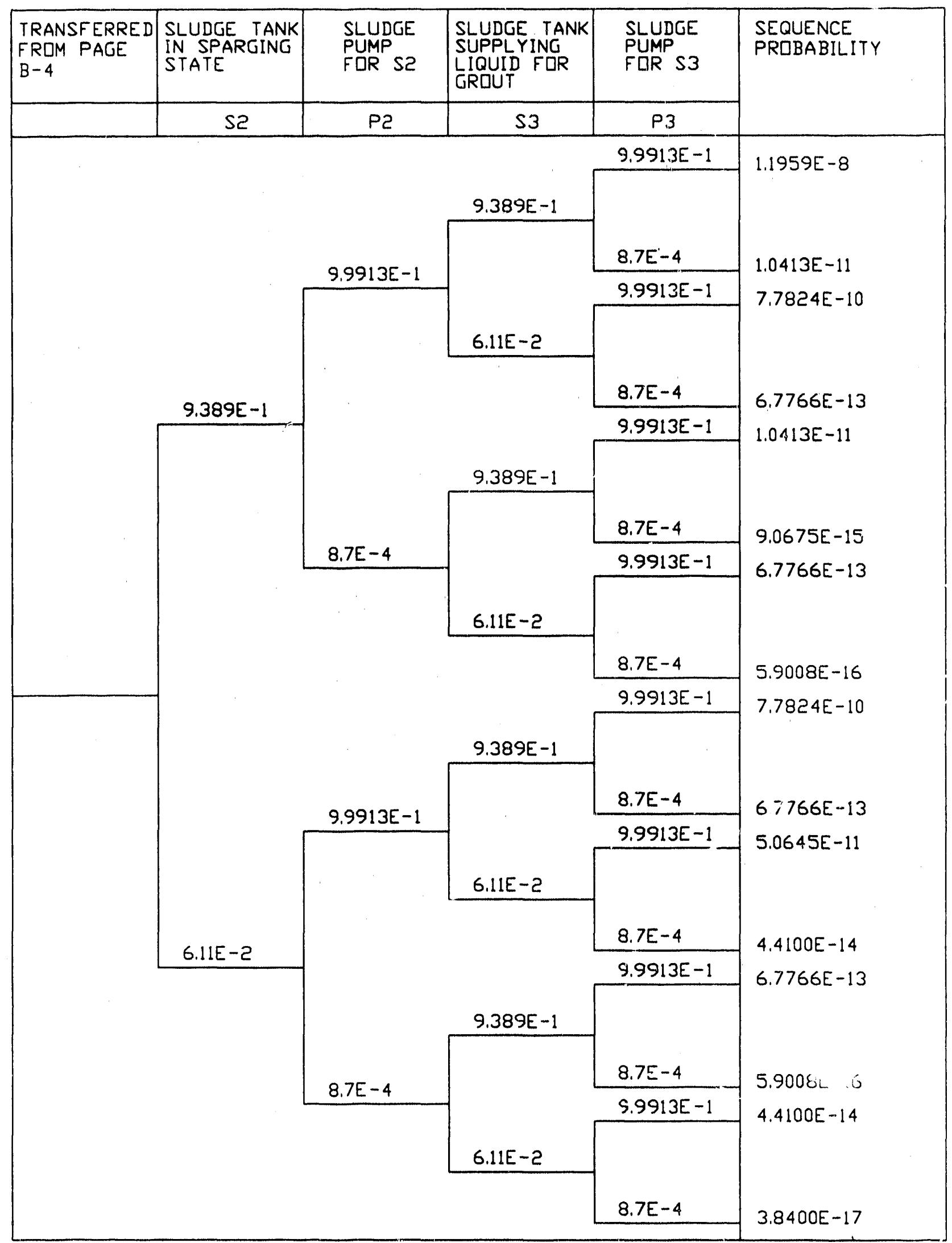

Figure B-3. Continued. (page 7 of 17) 


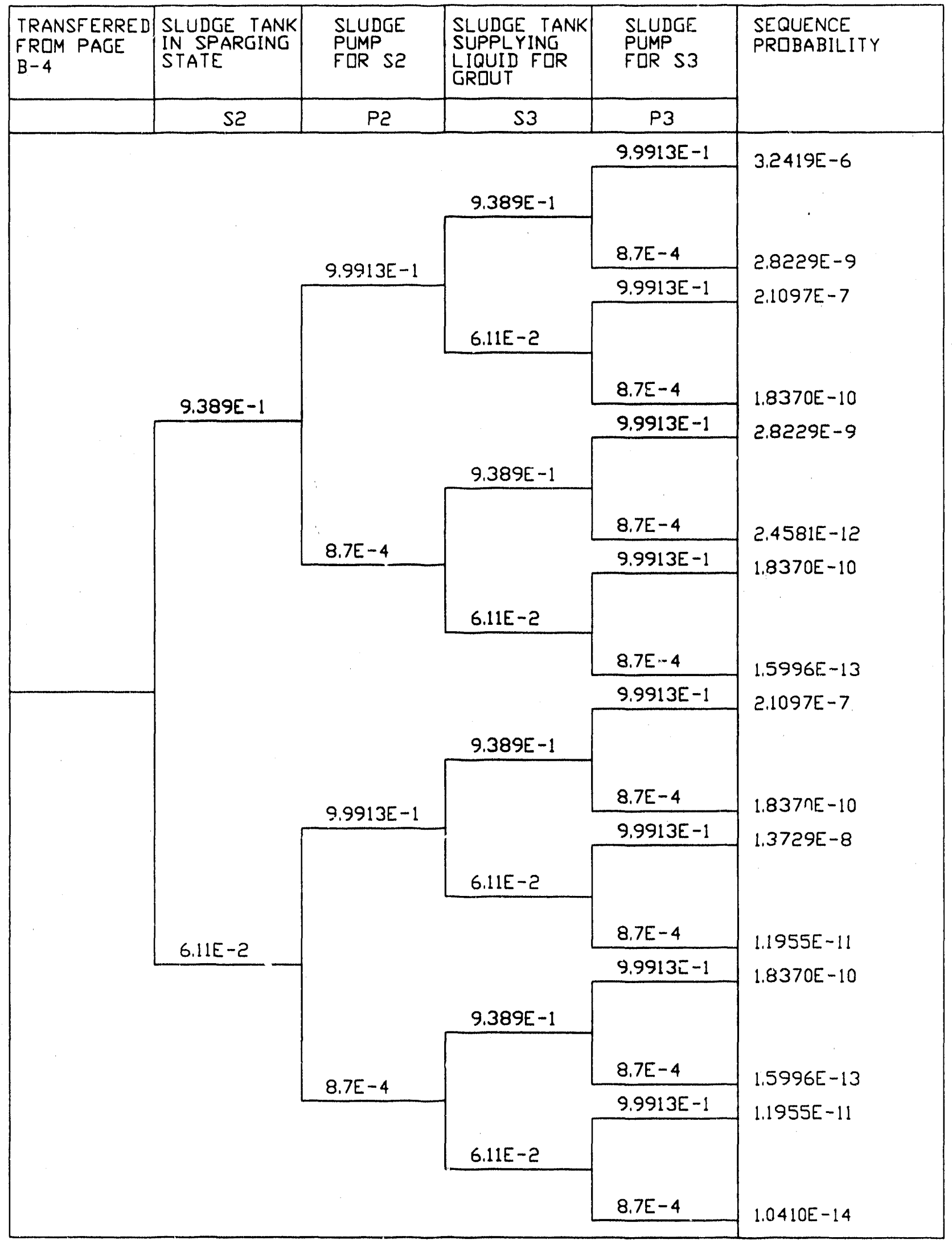

Figure B-3. Continued. (page 8 of 17) 




Figure B-3. Continued. (page 9 of 17) 




Figure B-3. Continued. (page 10 of 17) 


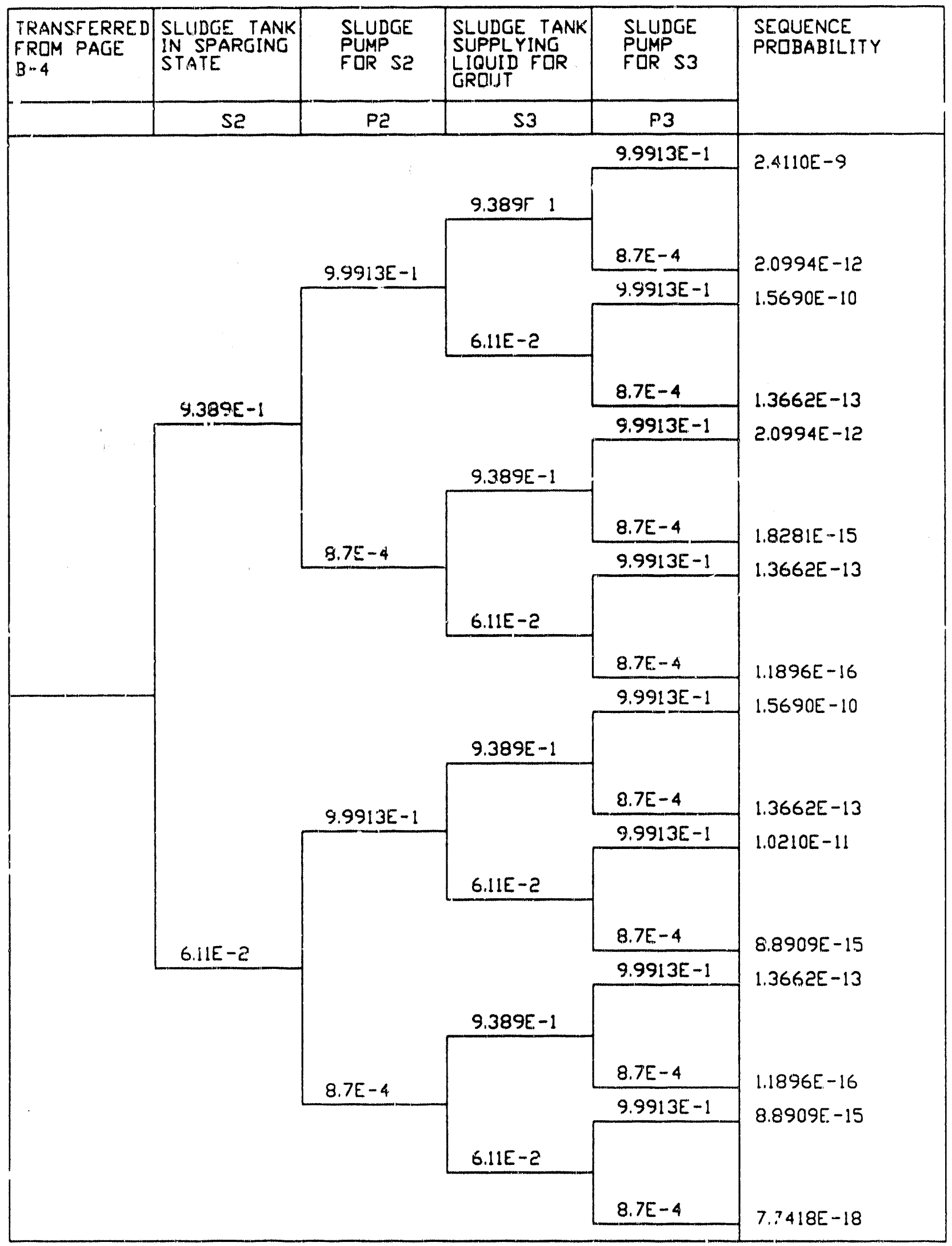

Figure 8-3. Continued. (page 11 of 17) 


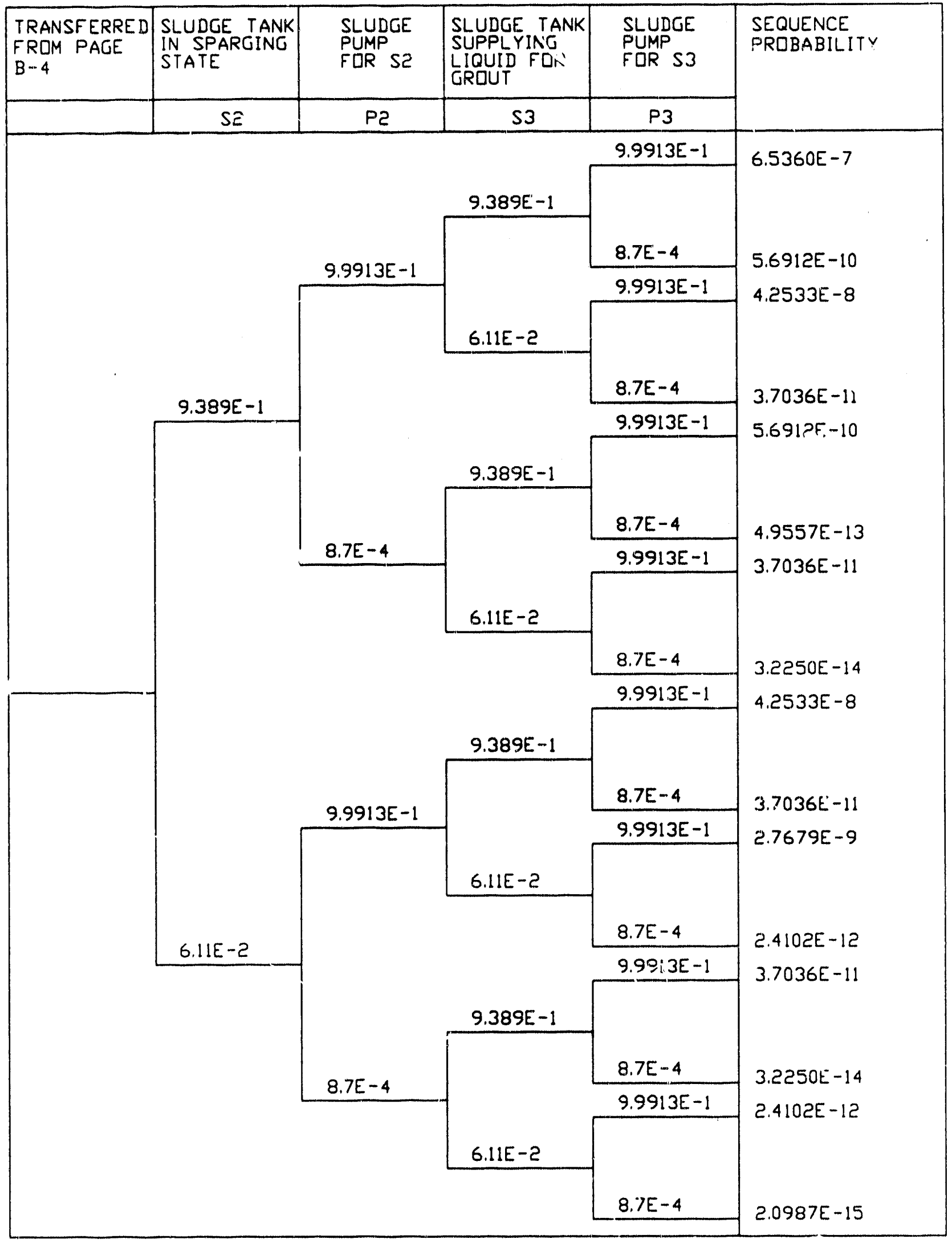

Figure B-3. Continued. (page 12 of 17) 


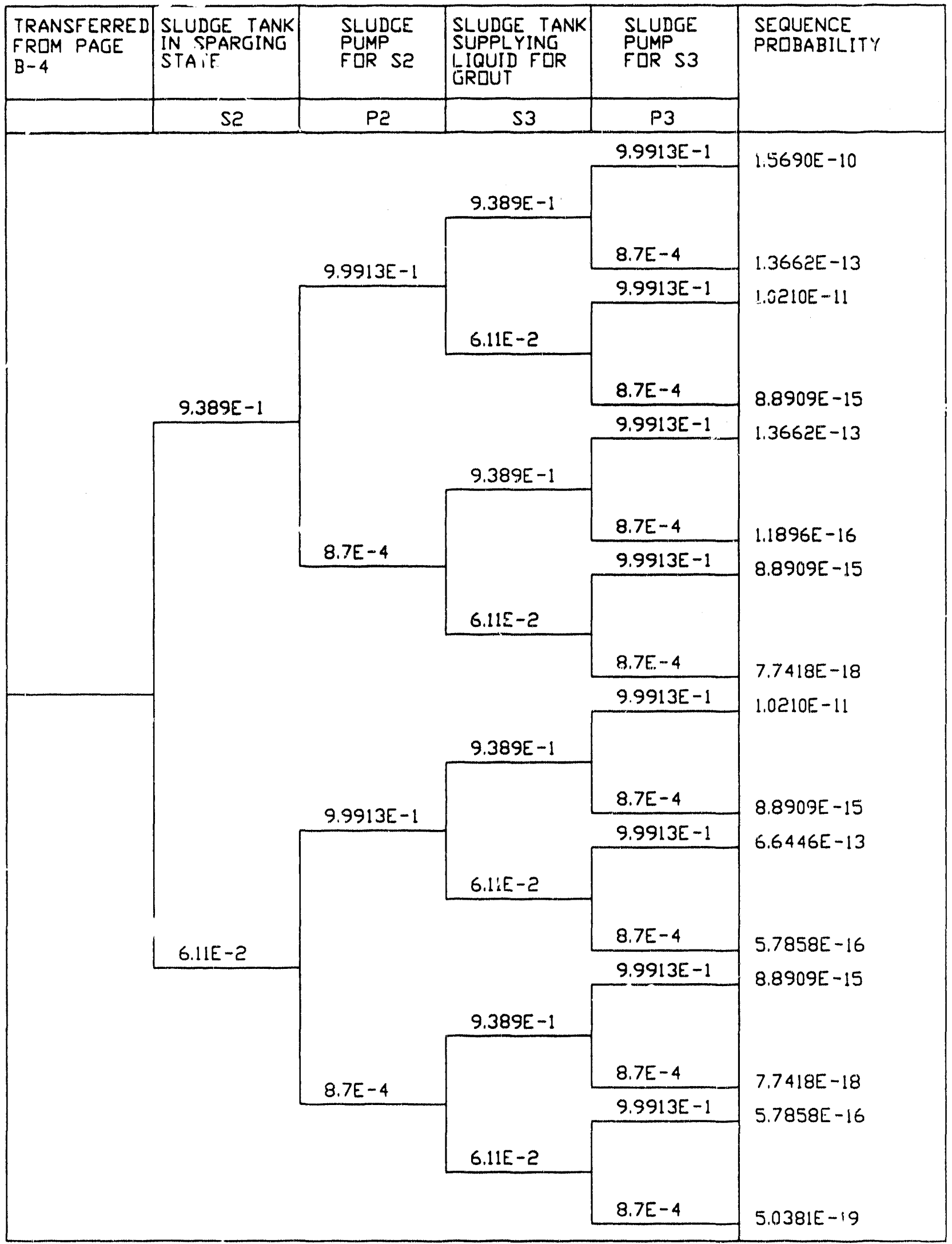

Figure B-3. Continued. (page 13 of 17) 


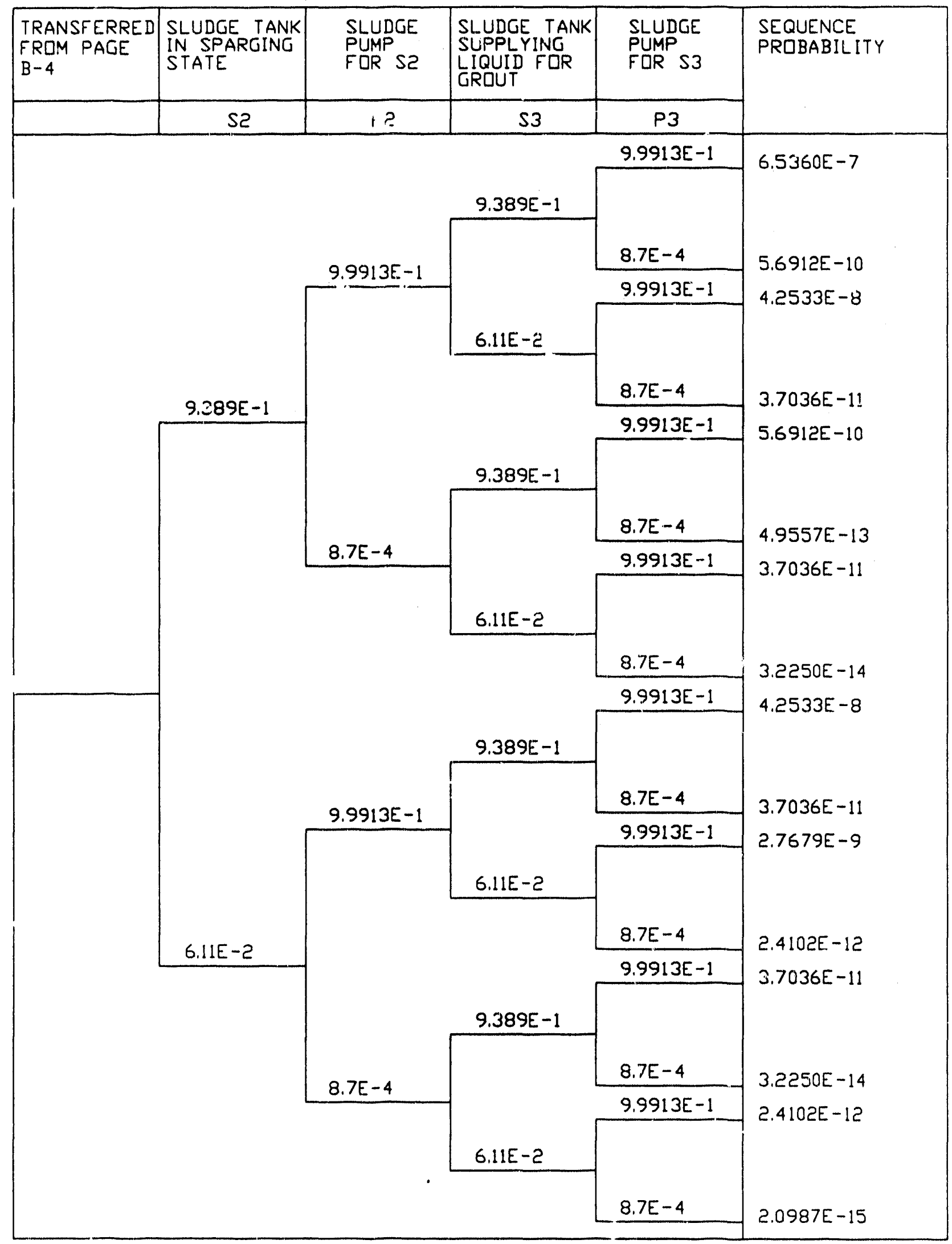

Figure B-3. Continued. (page 14 ( f 17) 


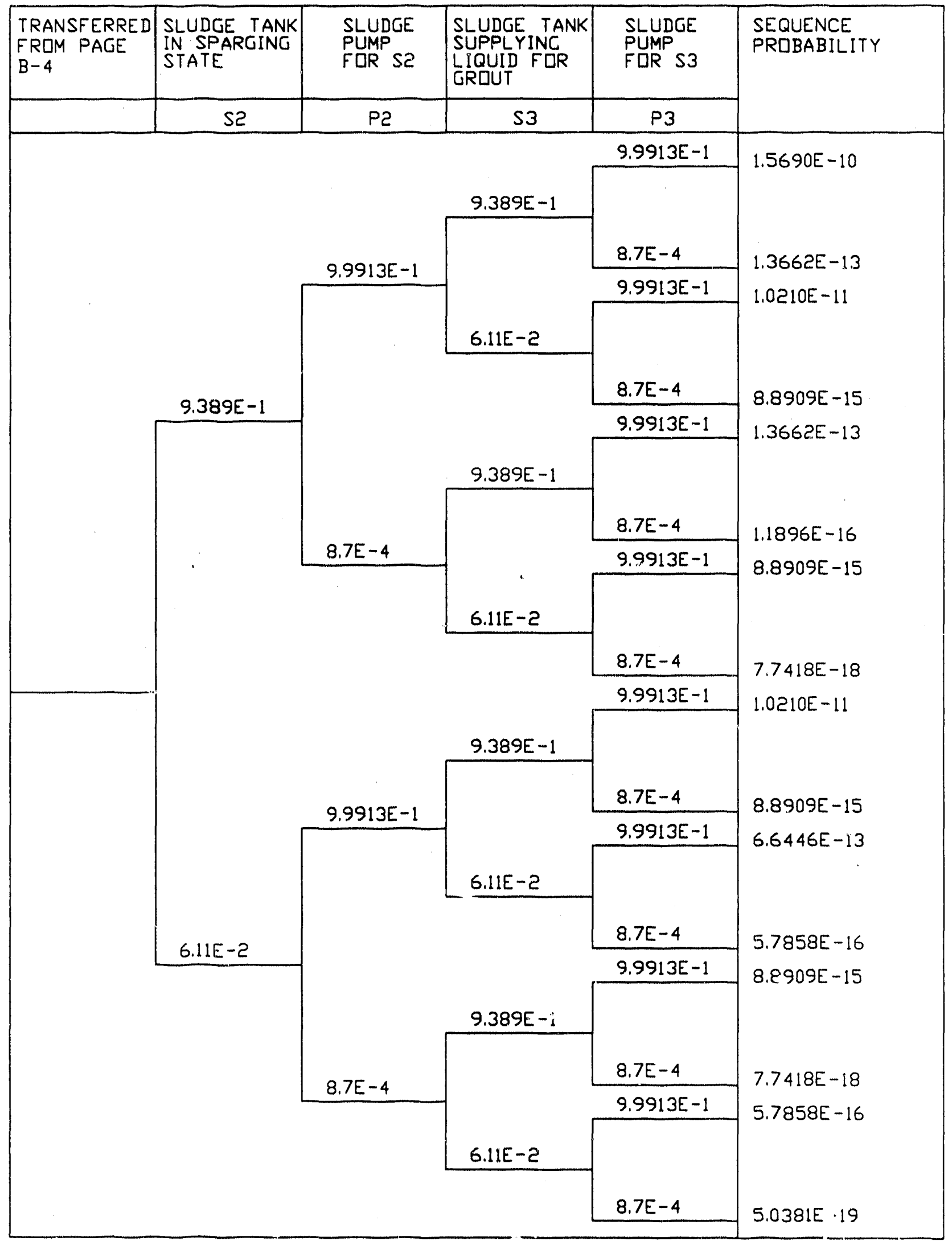

Figure B-3. Continued. (page 15 of 17) 


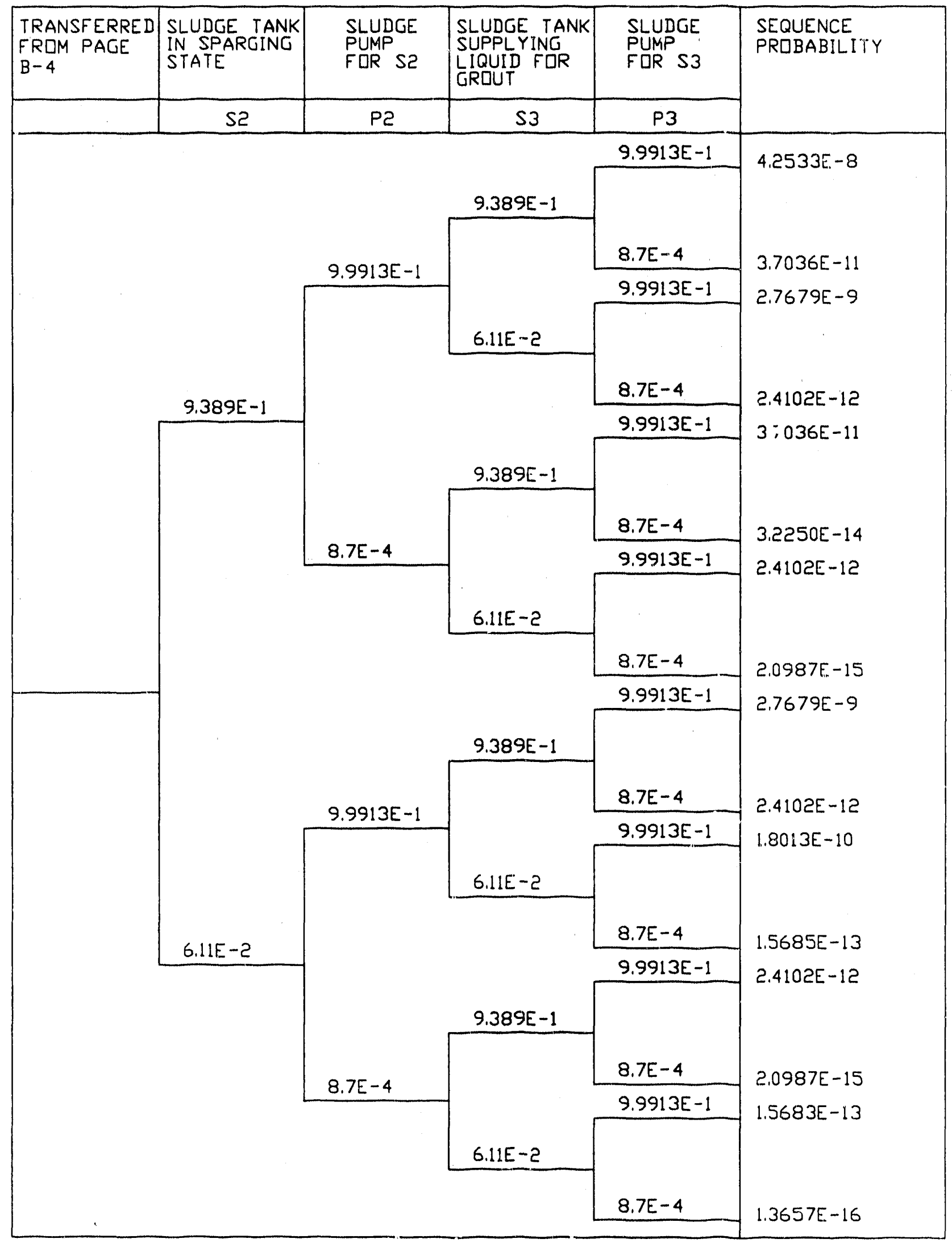

Figure B-3. Continued. (page 16 of 17) 


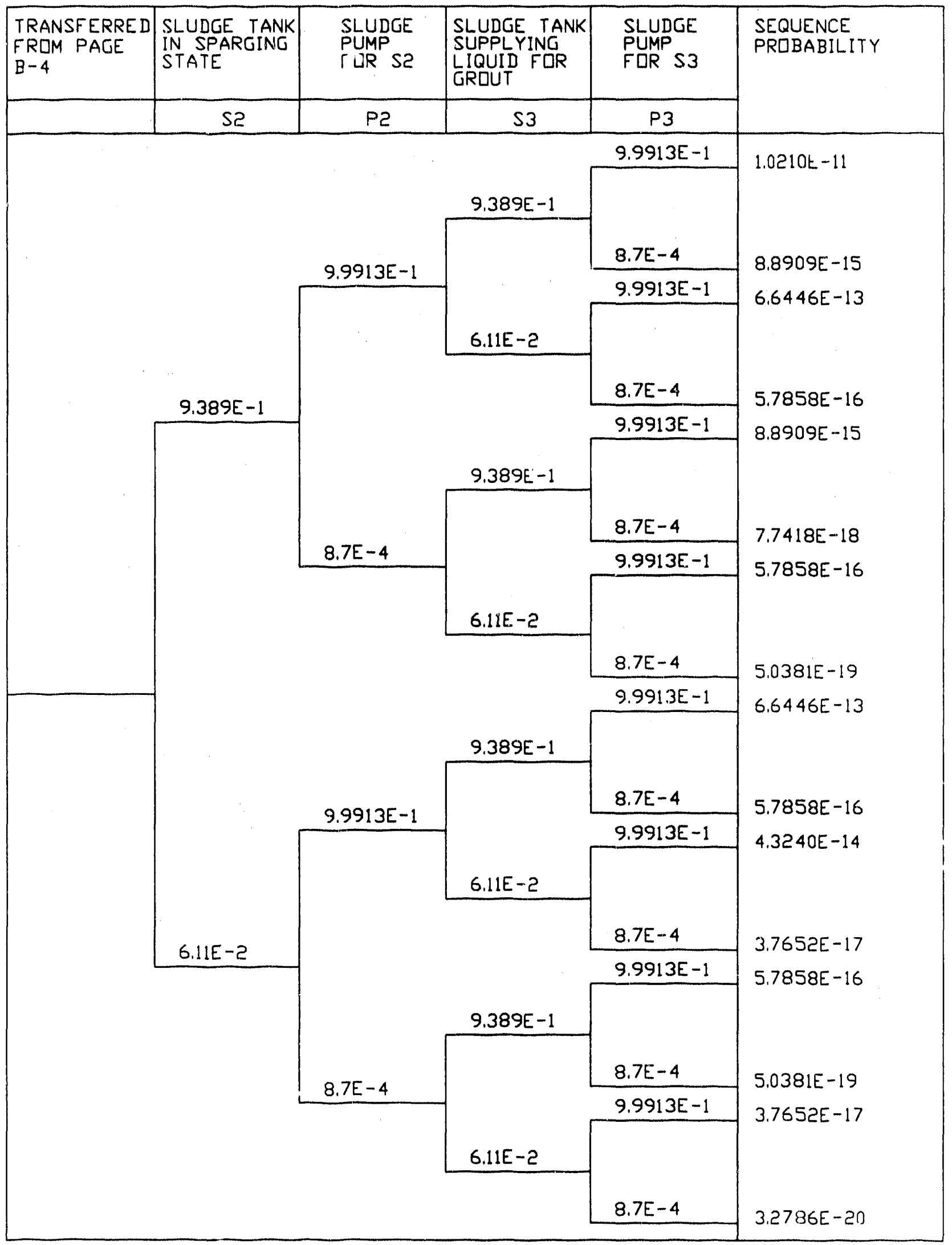

Figure B-3. Continued. (page 17 of 17) 


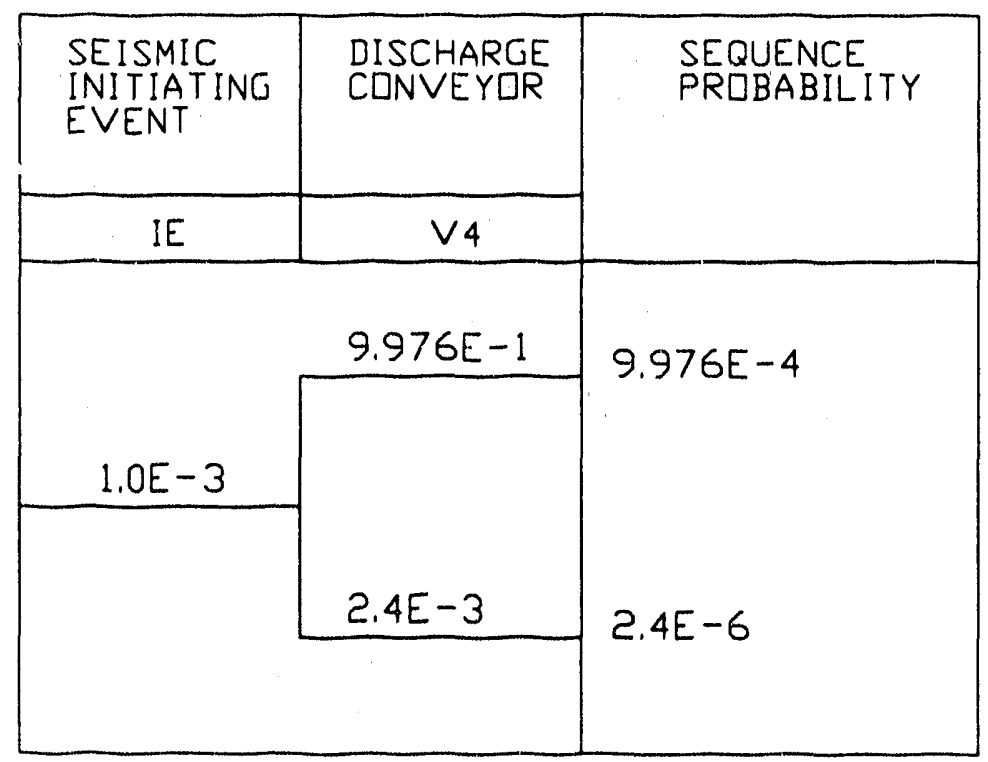

Figure B-4. Area 4 (solid) event tree. 




Figure B-5. Area 5 (fines) event tree. 


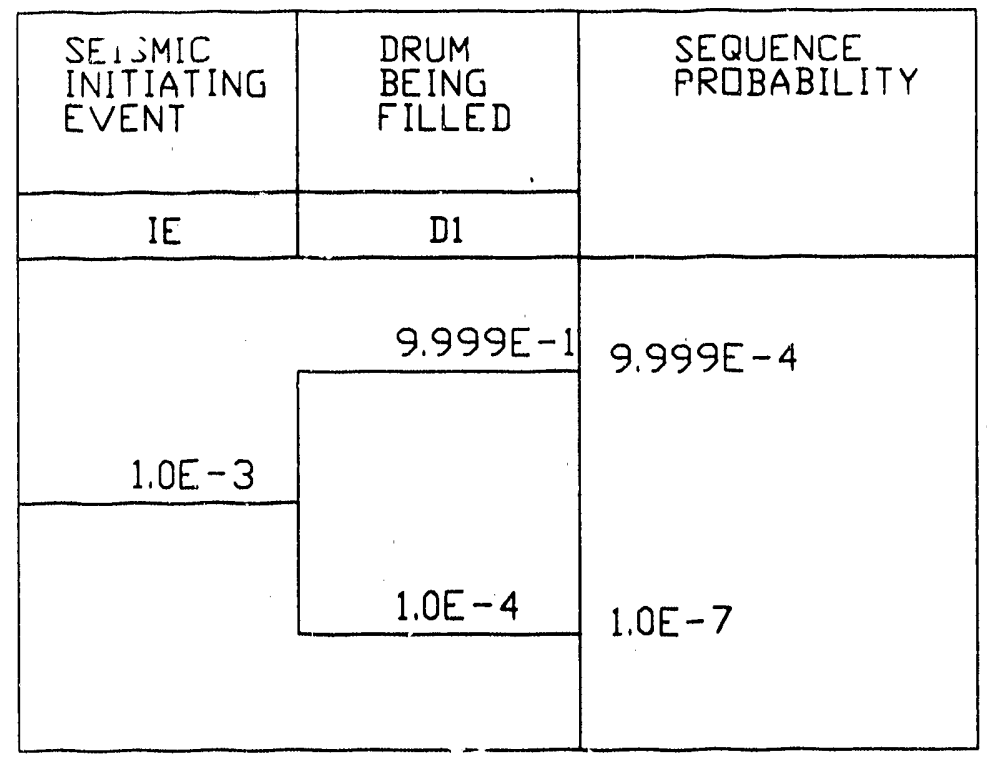

Figure B-6. Area 6 (flling) event tree. 


\begin{tabular}{|c|c|c|}
\hline $\begin{array}{l}\text { SEISMIC } \\
\text { INITIATING } \\
\text { EVENT }\end{array}$ & $\begin{array}{l}\text { GRDUTED } \\
\text { DRUM }\end{array}$ & $\begin{array}{l}\text { SEQUENCE } \\
\text { PROBABILITY }\end{array}$ \\
\hline IE & $\mathrm{D} 2$ & \multirow{4}{*}{$9.83 E-4$} \\
\hline \multirow[b]{2}{*}{ 1.DE - 3} & $9.83 E-1$ & \\
\hline & \multirow{2}{*}{$1.7 E-2$} & \\
\hline & & \\
\hline
\end{tabular}

Figure B-8. Area 8 (curing) event tree. 


\begin{tabular}{|c|c|c|}
\hline $\begin{array}{l}\text { SEISMIC } \\
\text { INITIATING } \\
\text { EVENT }\end{array}$ & $\begin{array}{l}\text { HVAC } \\
\text { SYSTEM }\end{array}$ & $\begin{array}{l}\text { SEQUENCE } \\
\text { PRQBABILITY }\end{array}$ \\
\hline IE & B1 & \\
\hline \multirow{3}{*}{$1.0 E-3$} & $9.1 E-1$ & \multirow[t]{3}{*}{$9.1 E-4$} \\
\hline & & \\
\hline & $9.0 E-2$ & \\
\hline
\end{tabular}

Flgure B-9, Area 9 (HVAC) event tree. 
APPENDIX C

TRANSPORT DATA PLOTS 


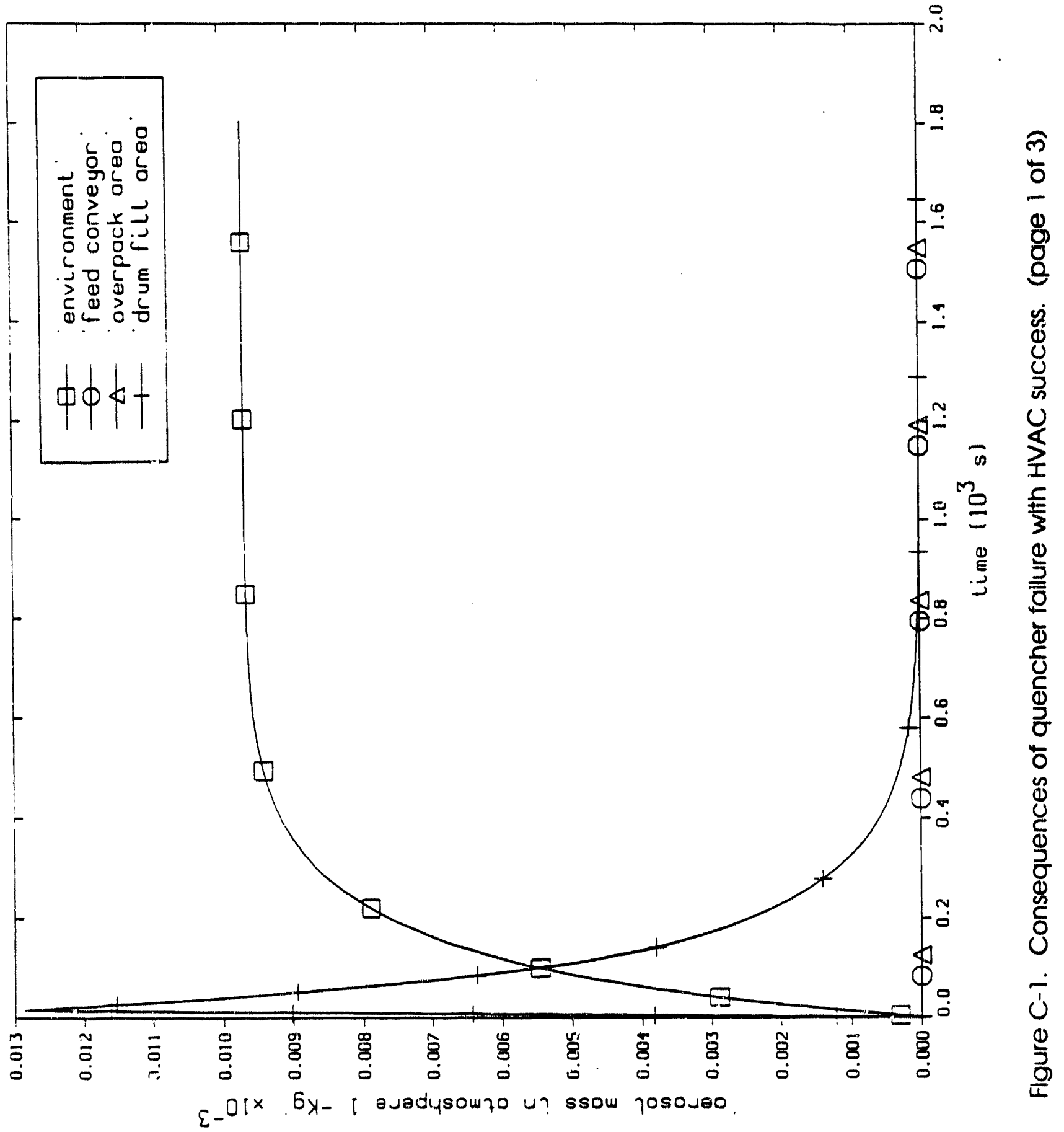

C-2 


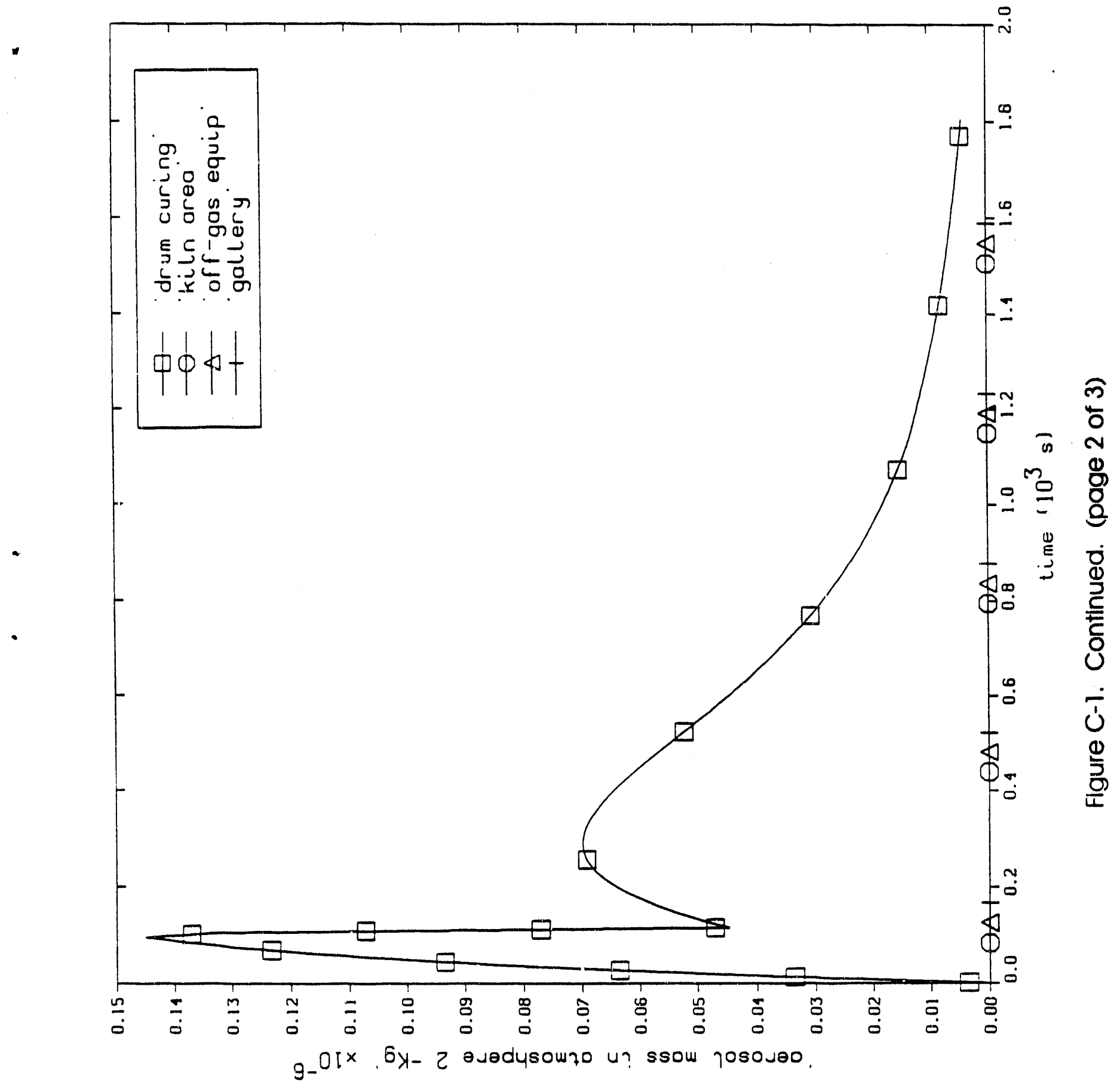

C-3 


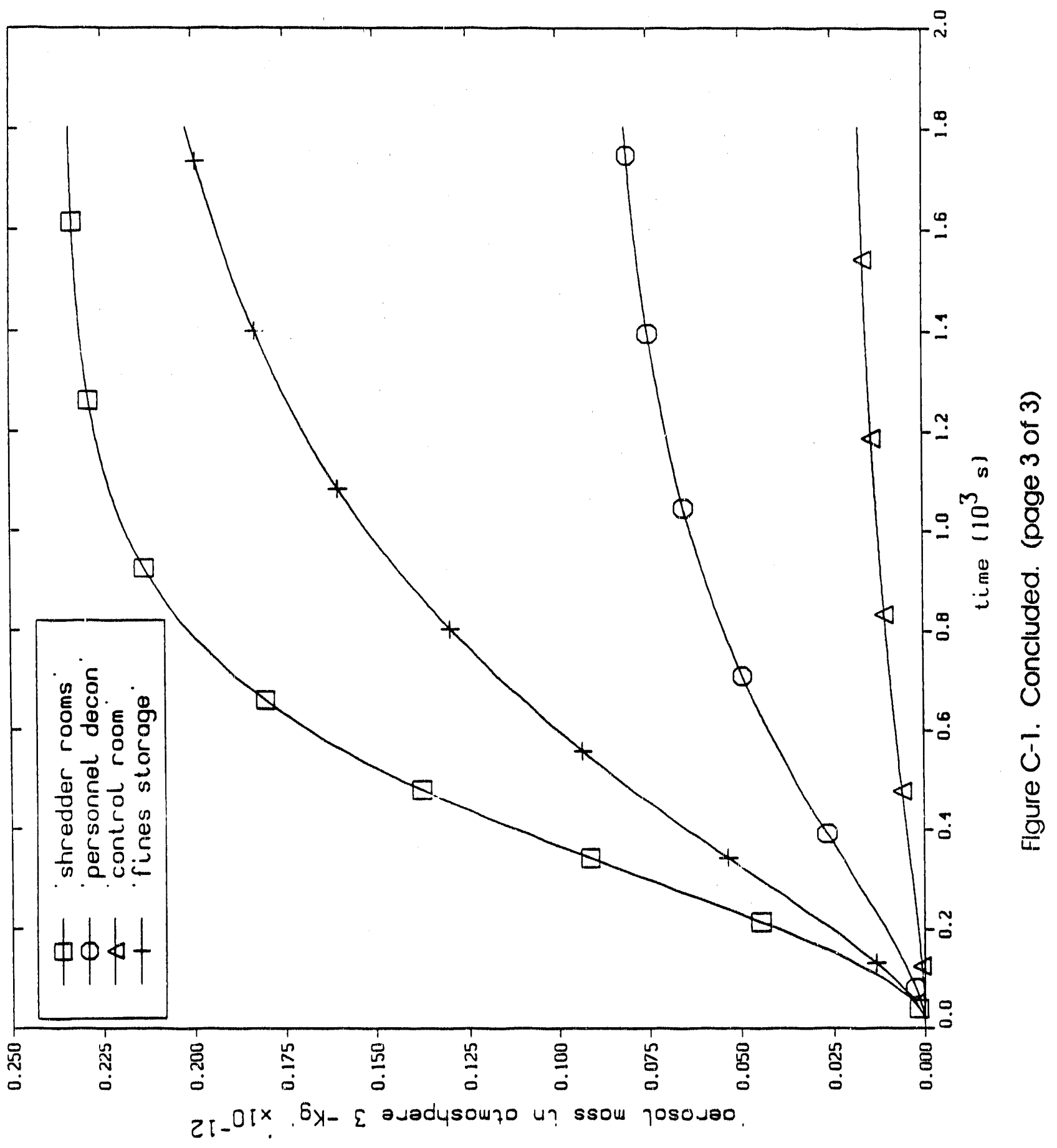

C-4 


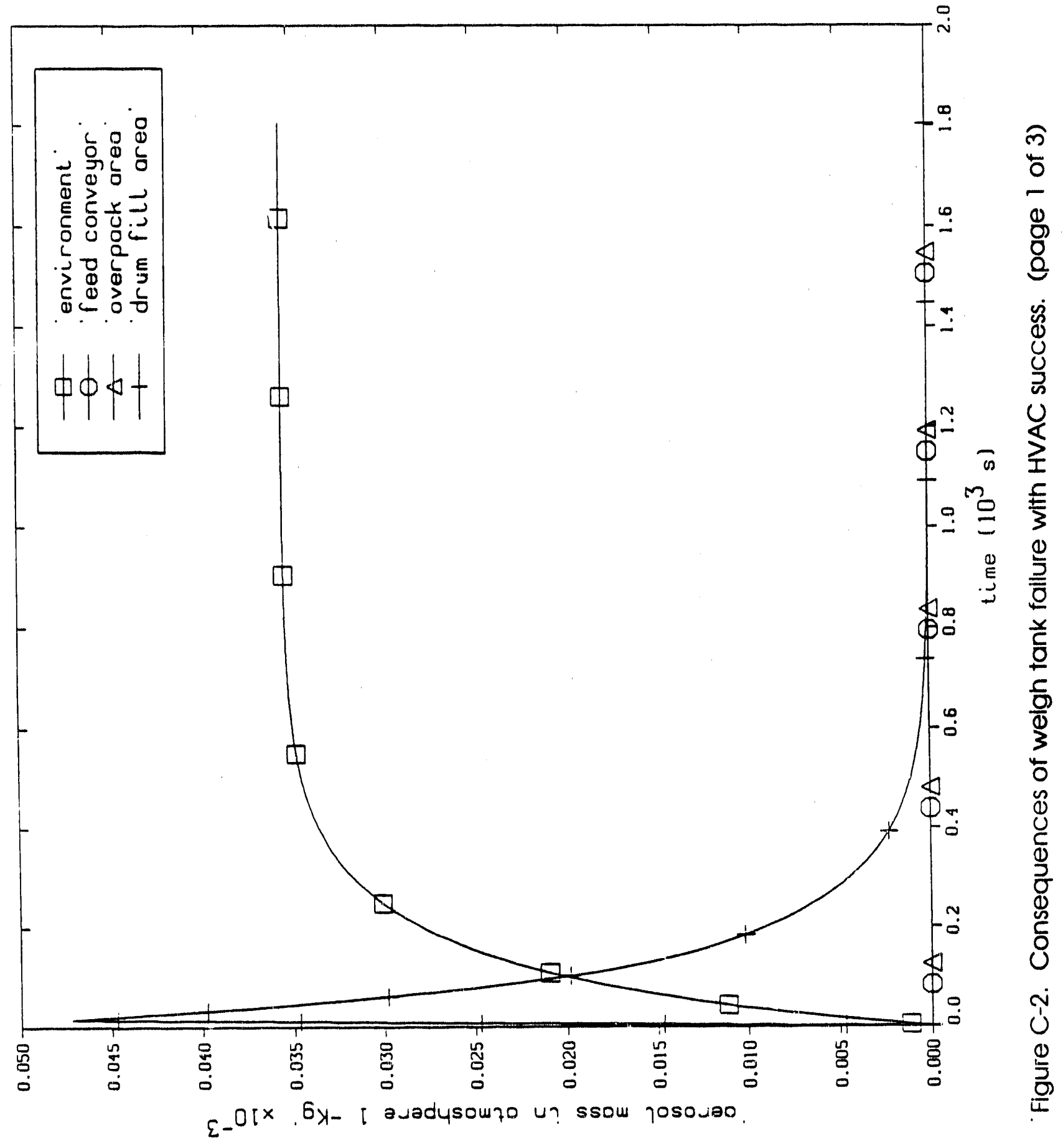

C-5 


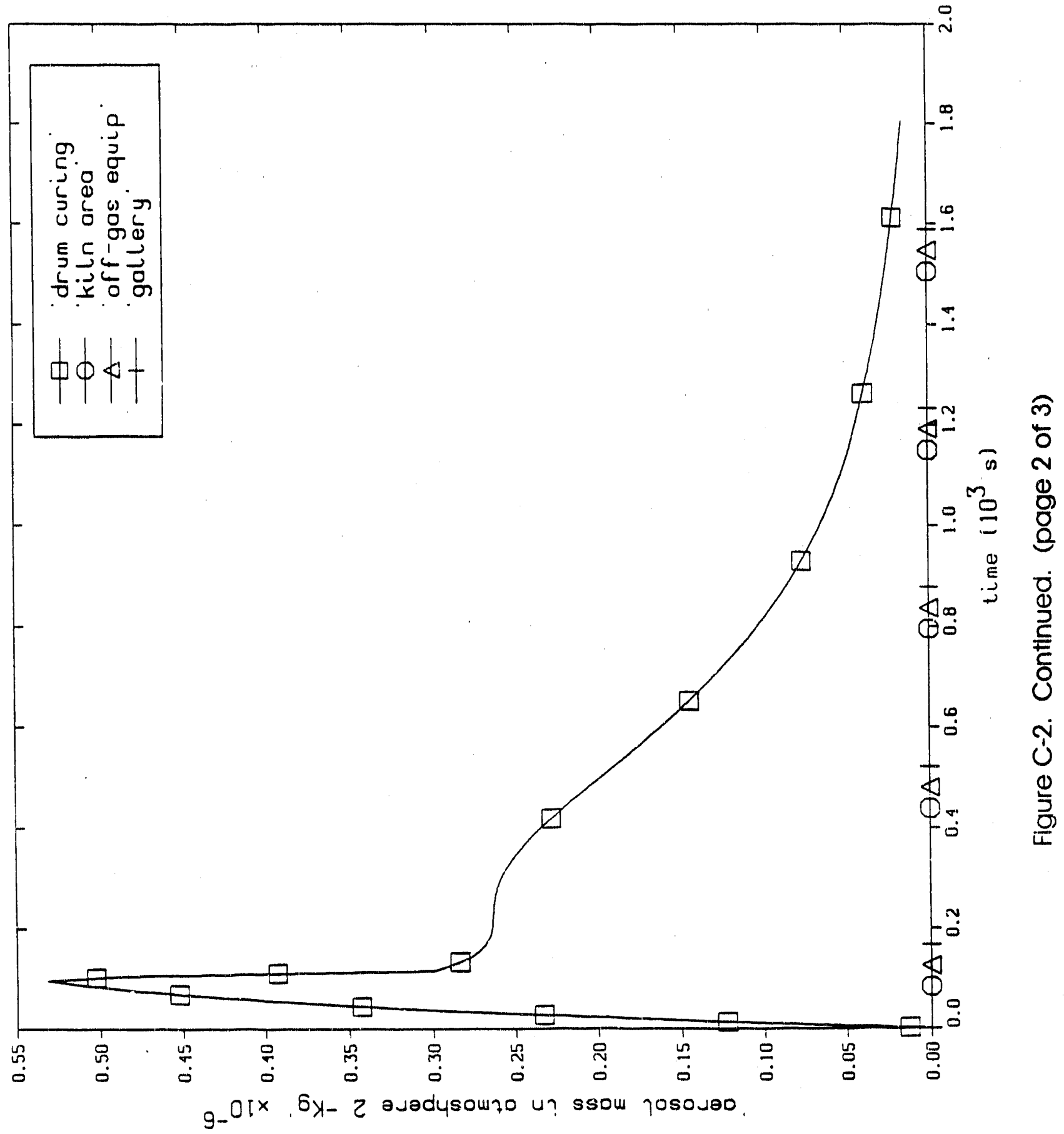




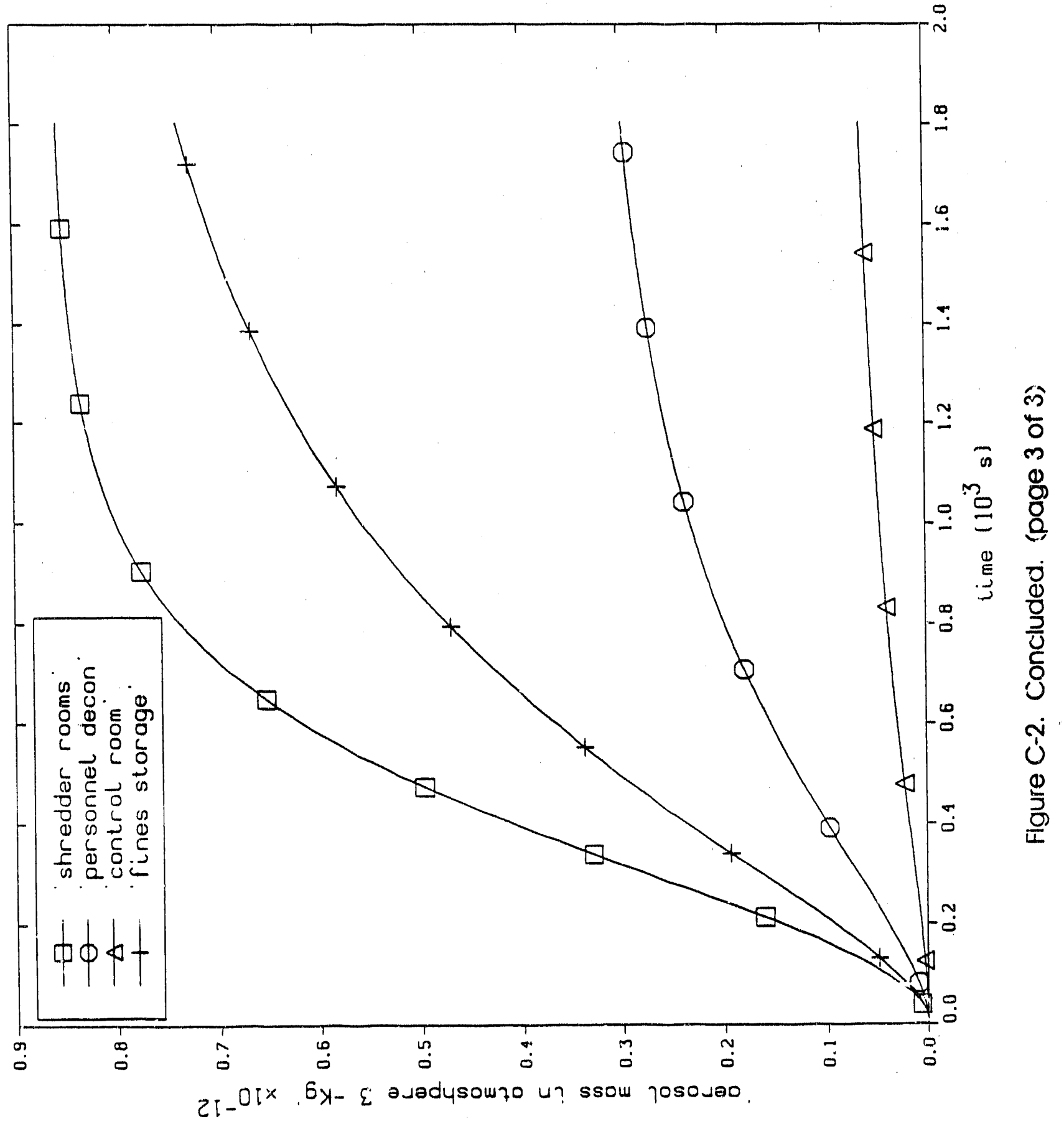

C. 7 


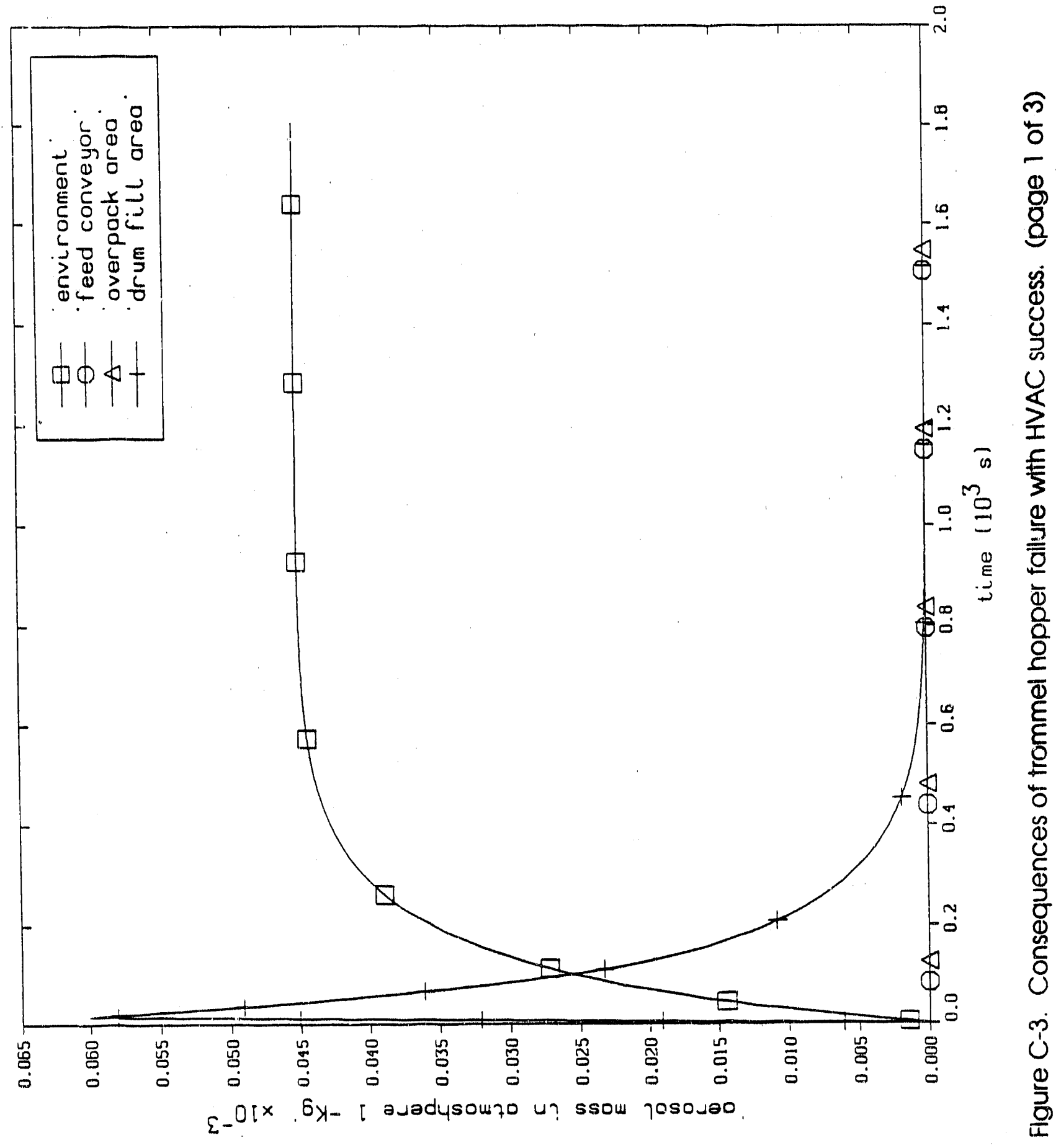






C-9 


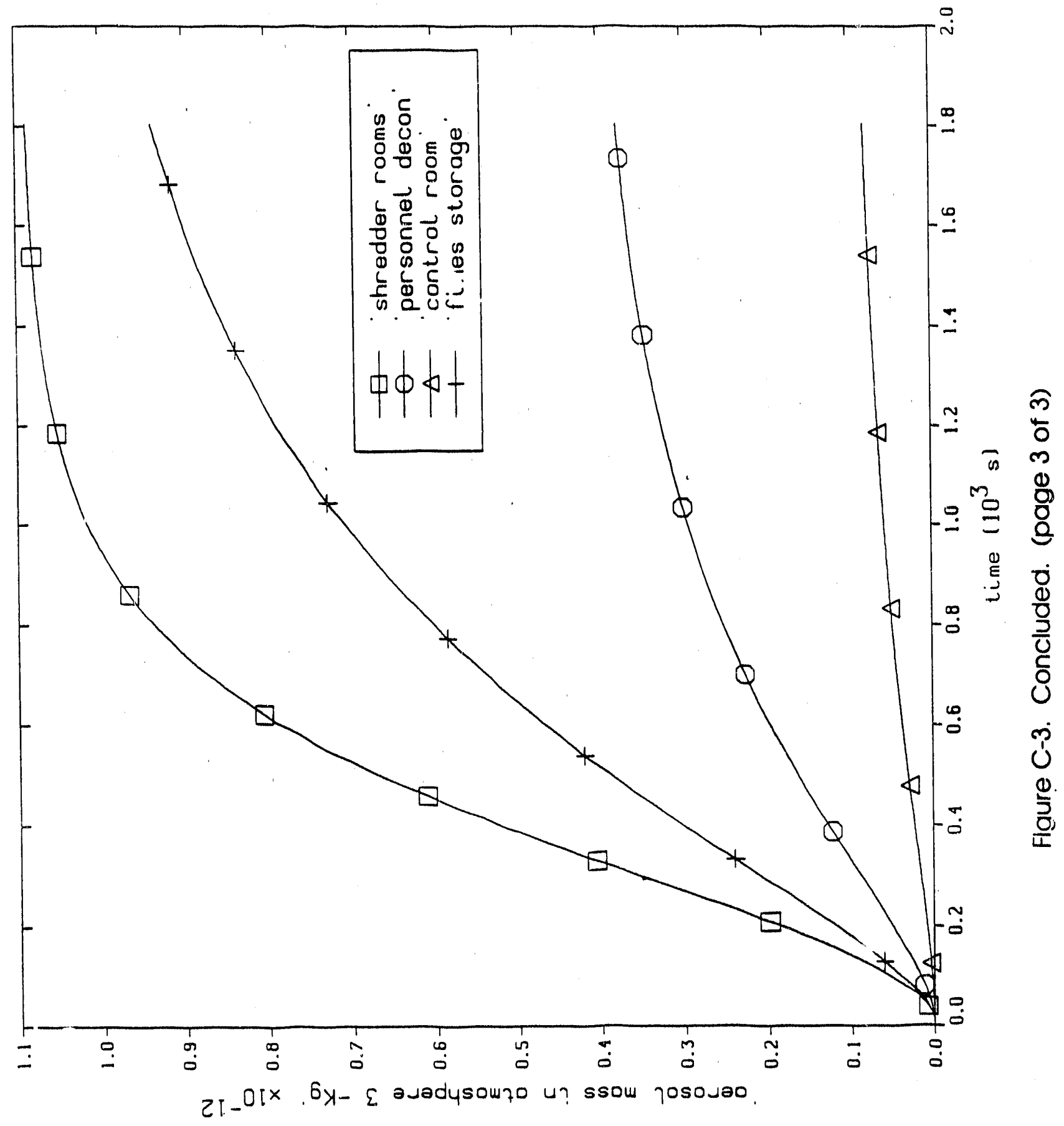

C- 10 


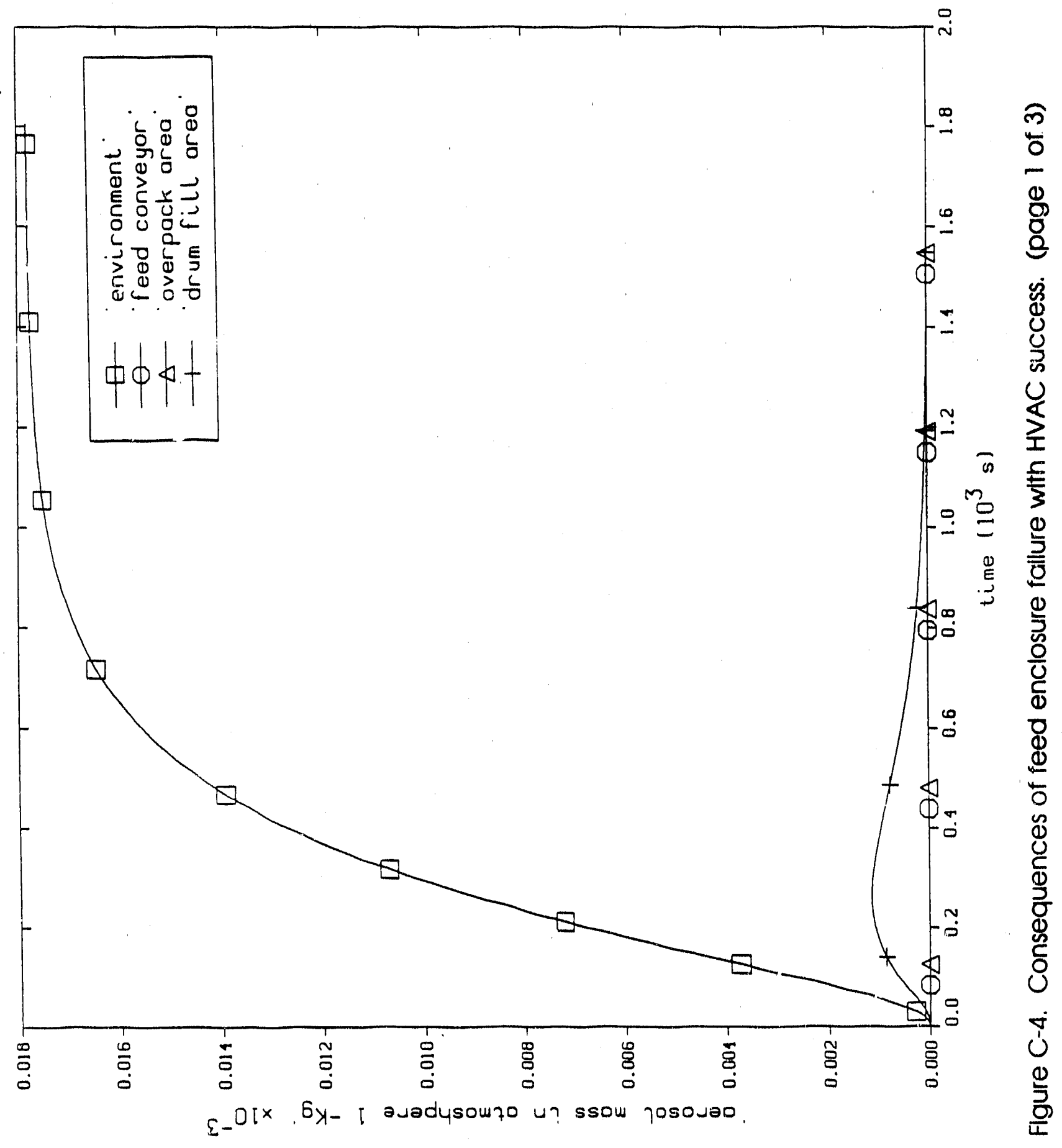

C-11 


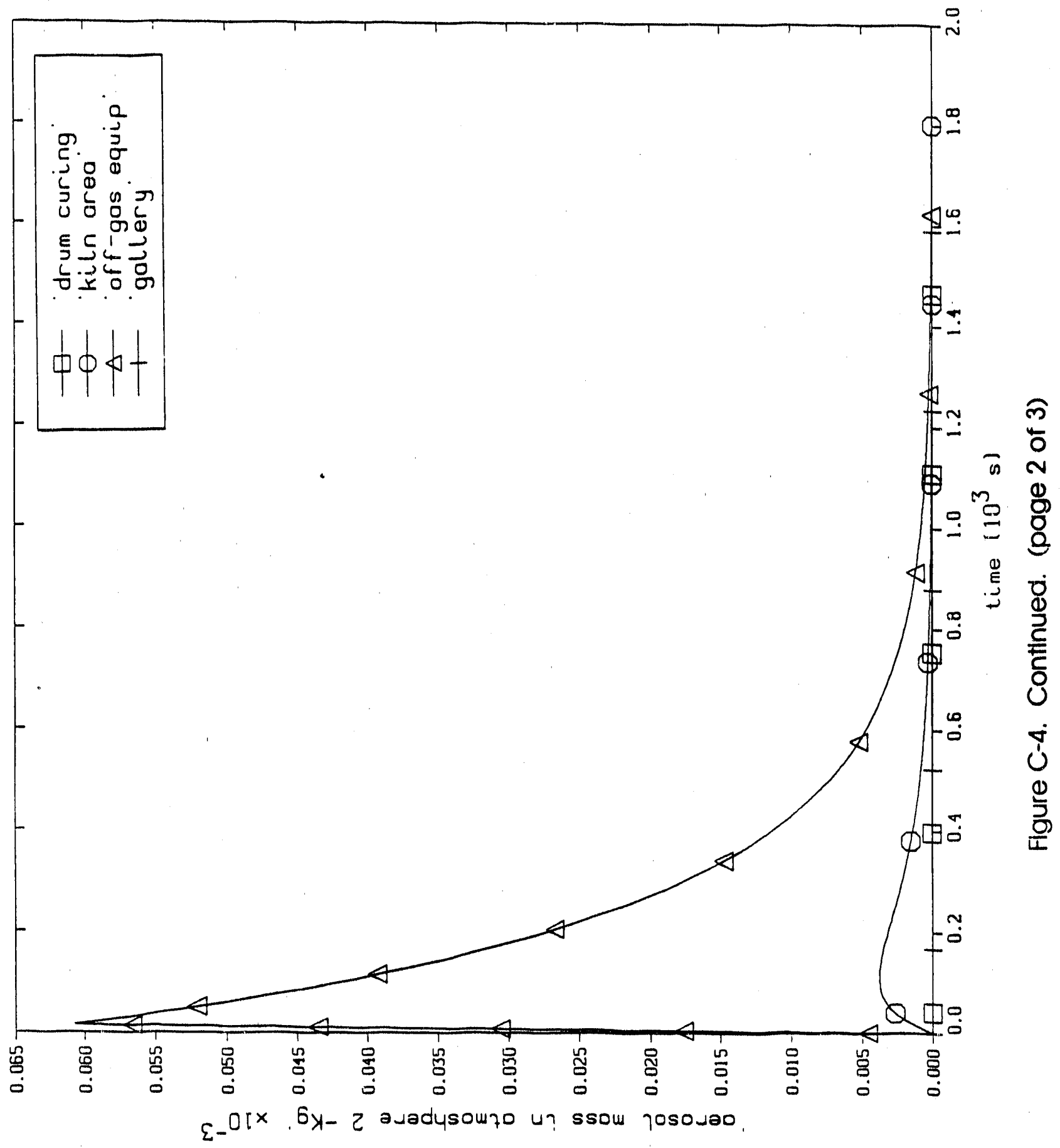

C- 12 


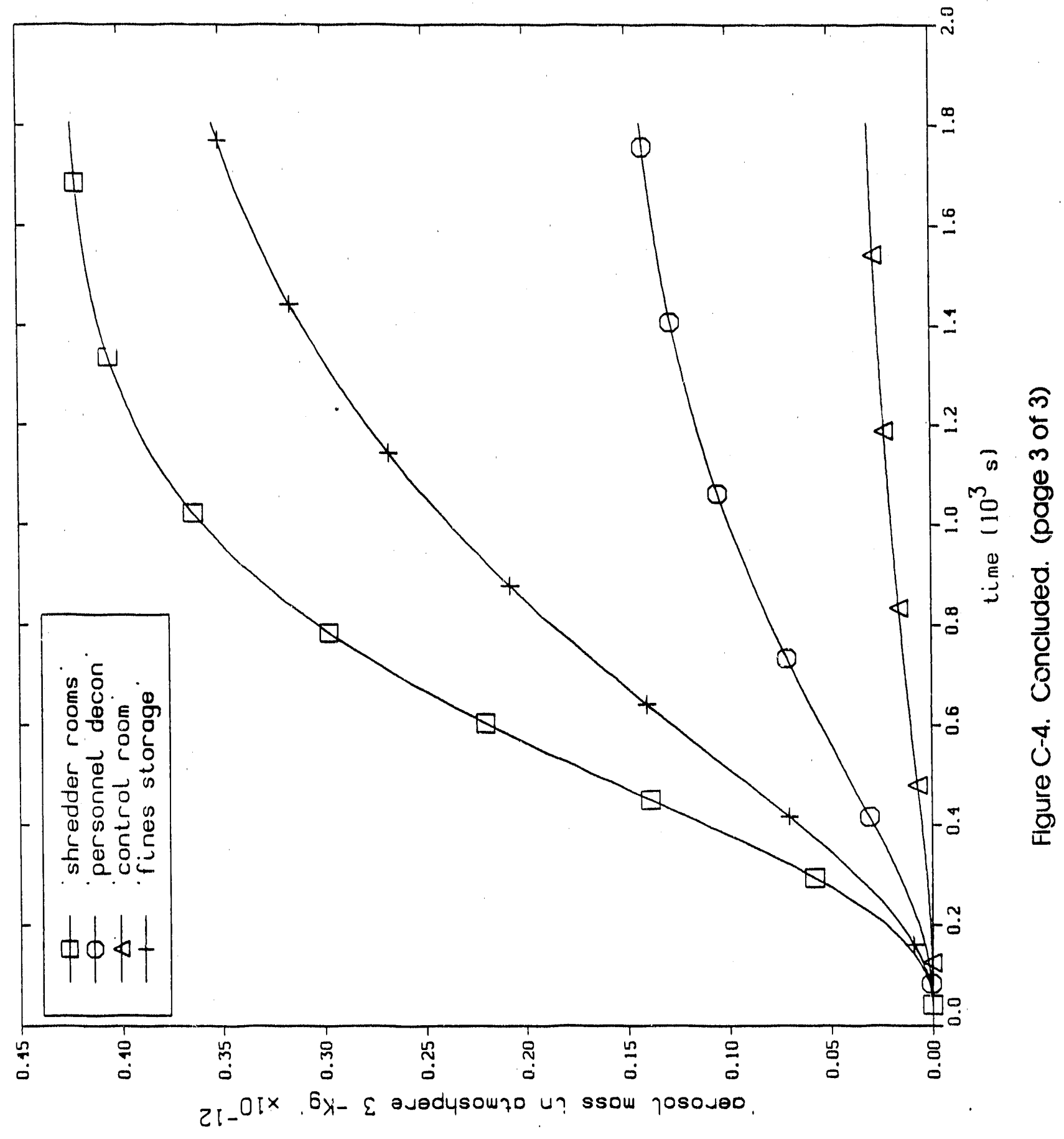

C-13 




C-14 


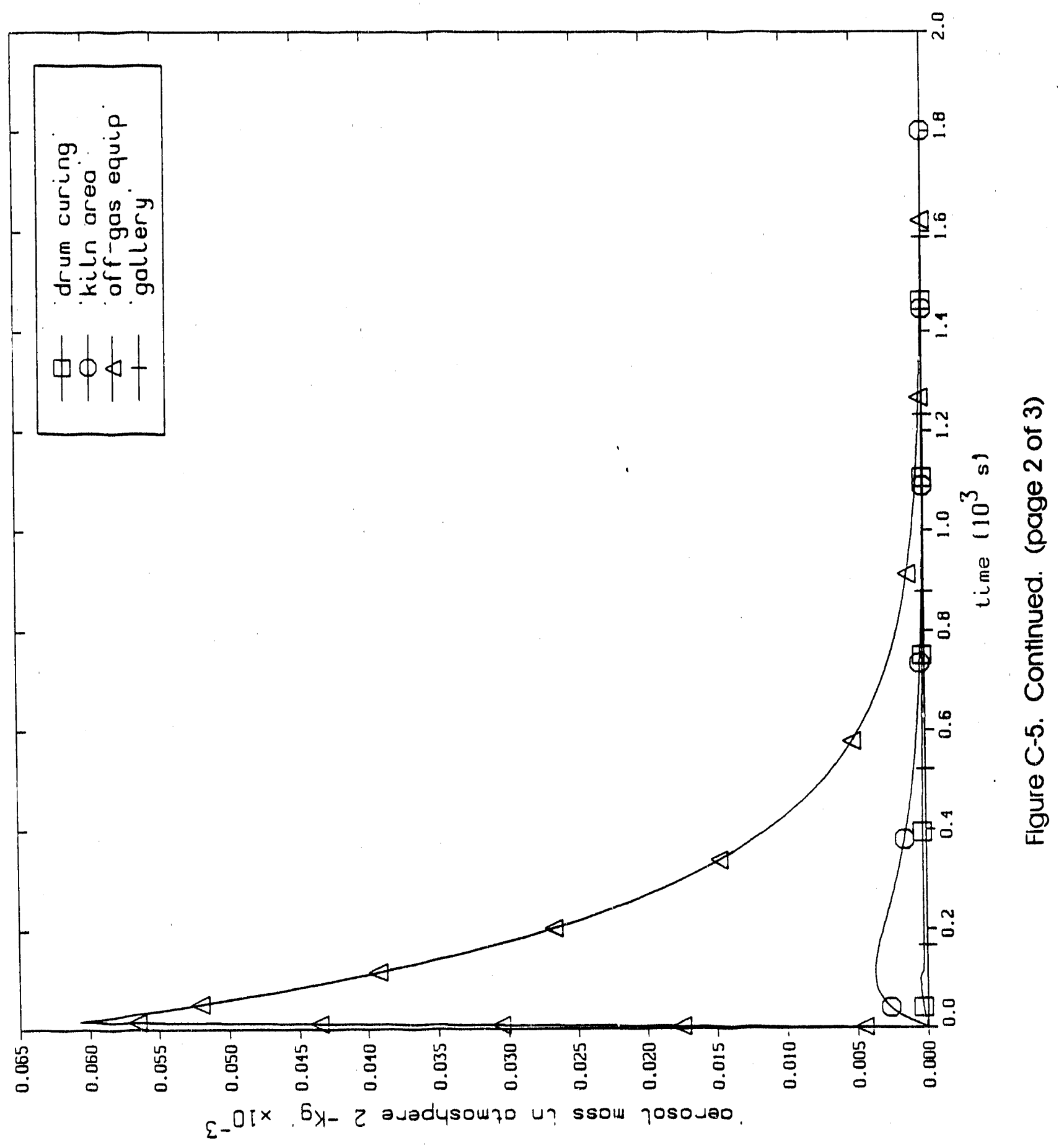

C- 15 


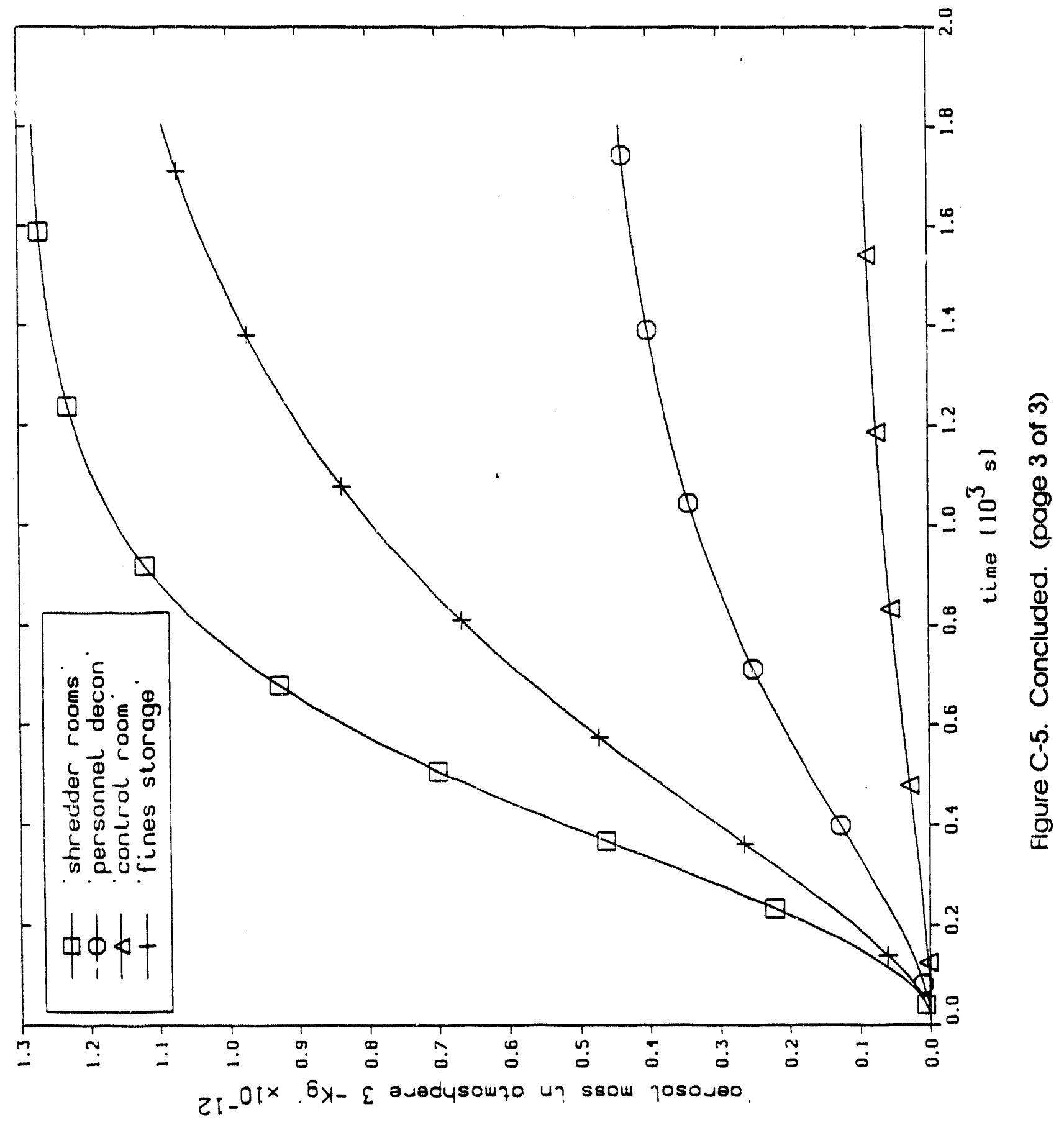

C- 16 







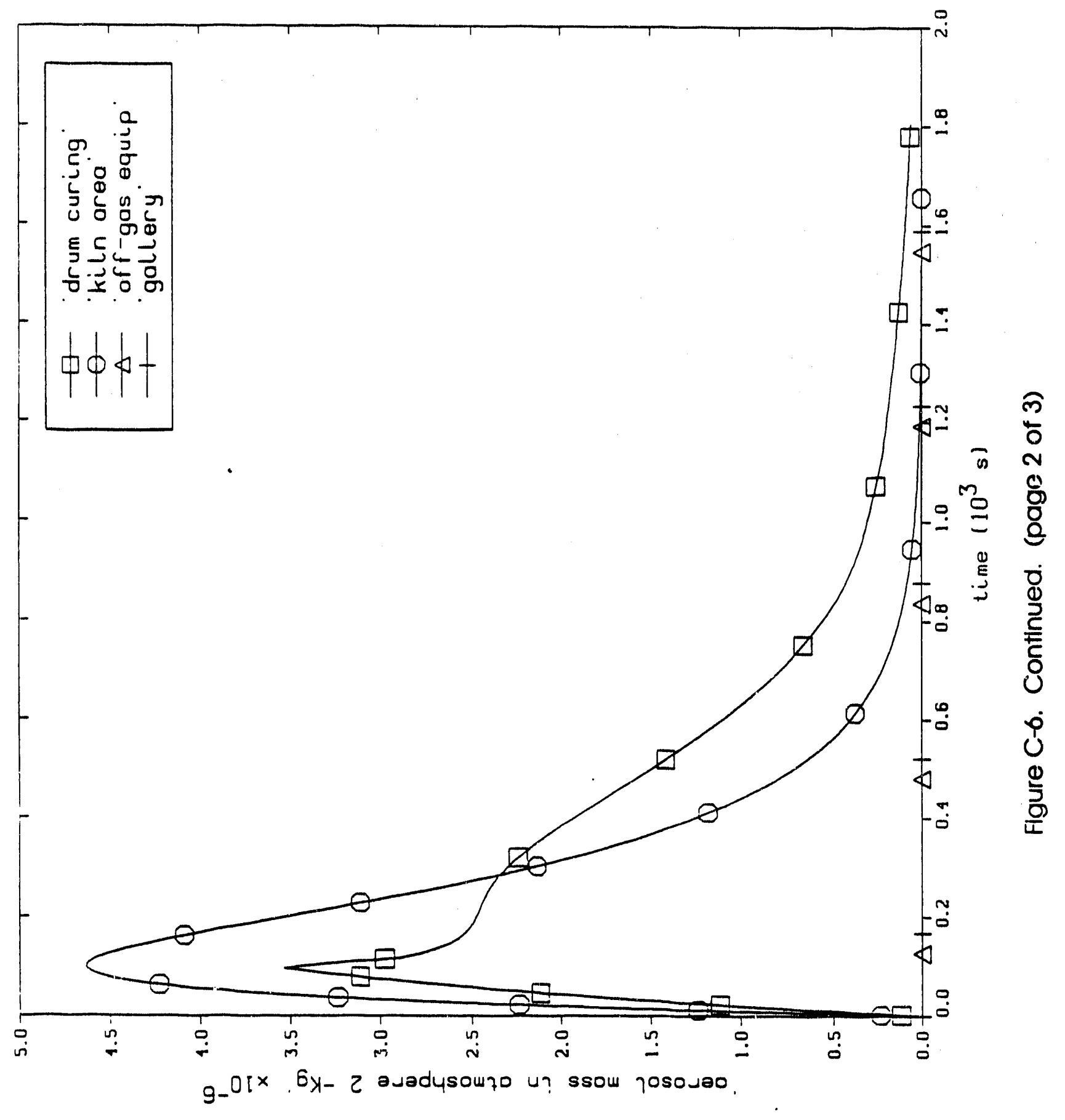

C. -18 


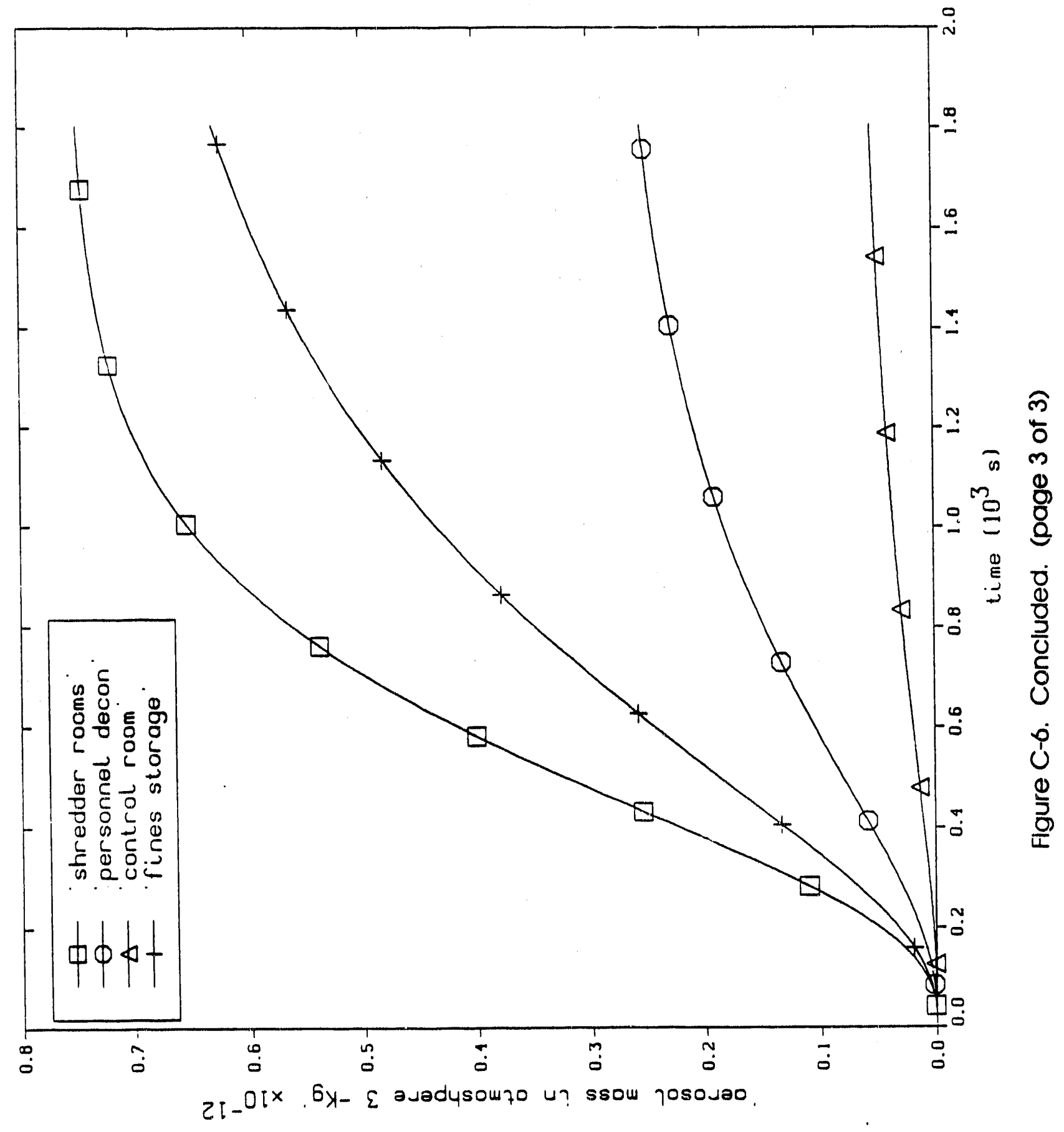

C- 19 







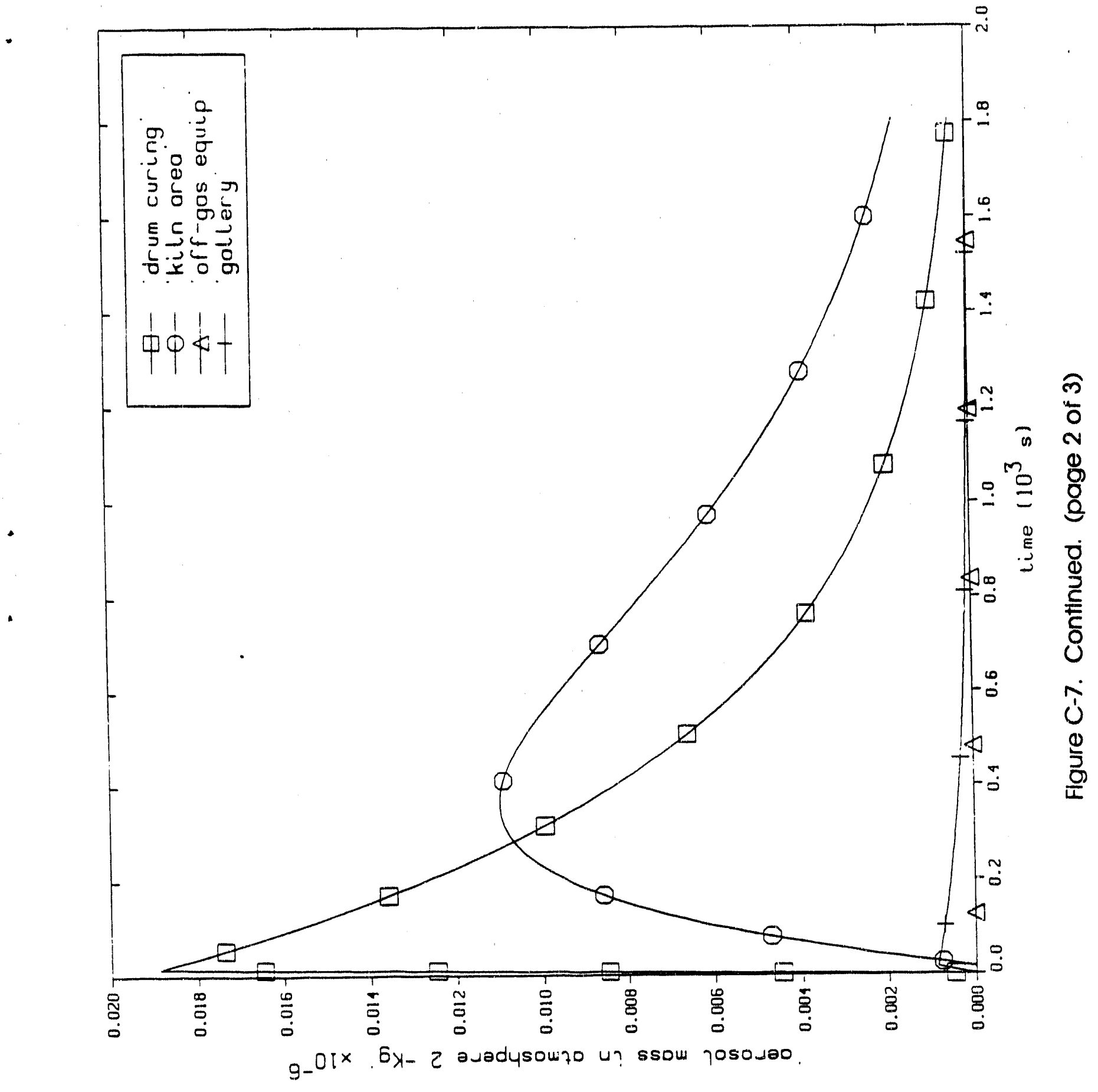

C-21 




C-22 


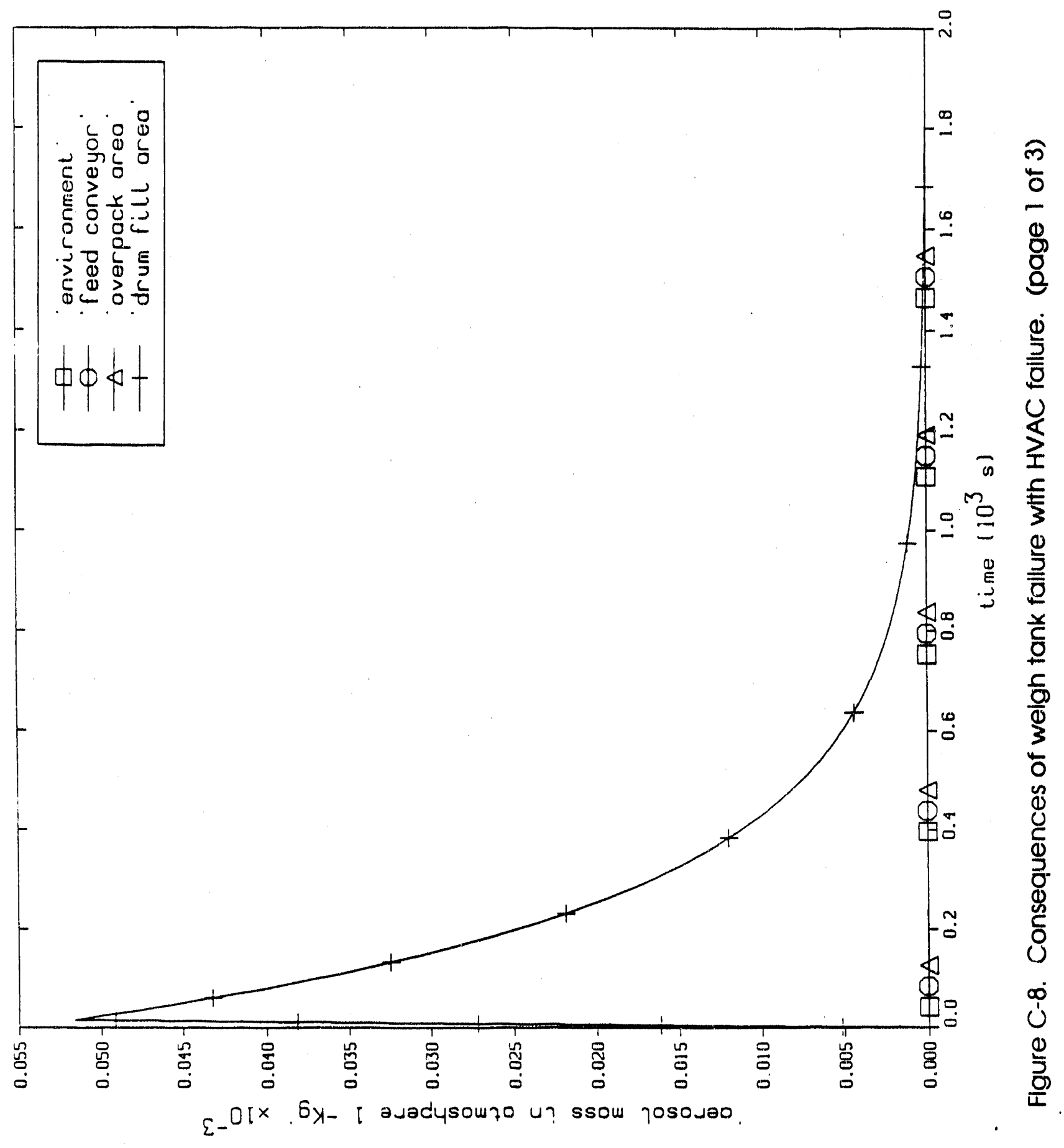

C- 23 


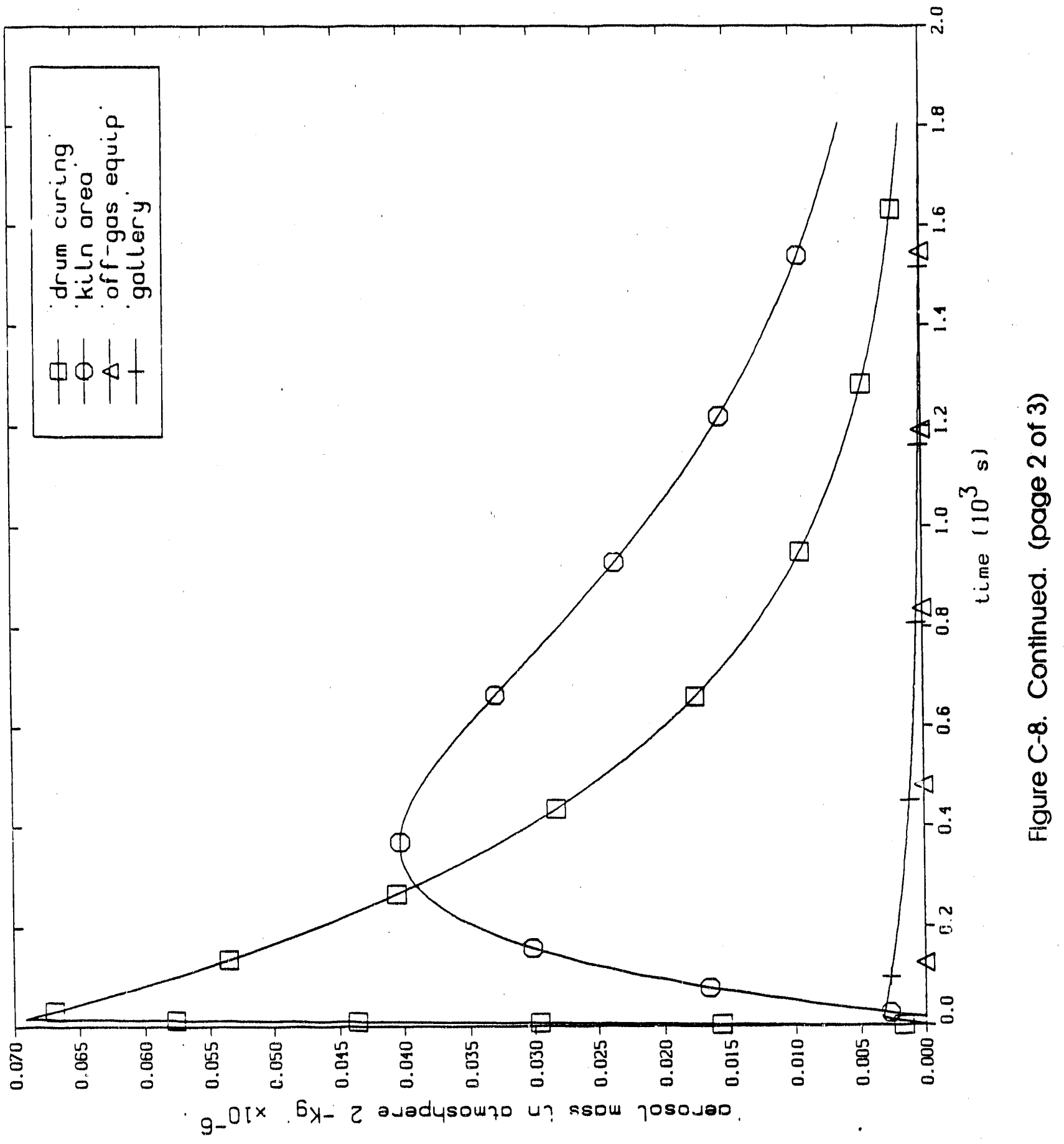




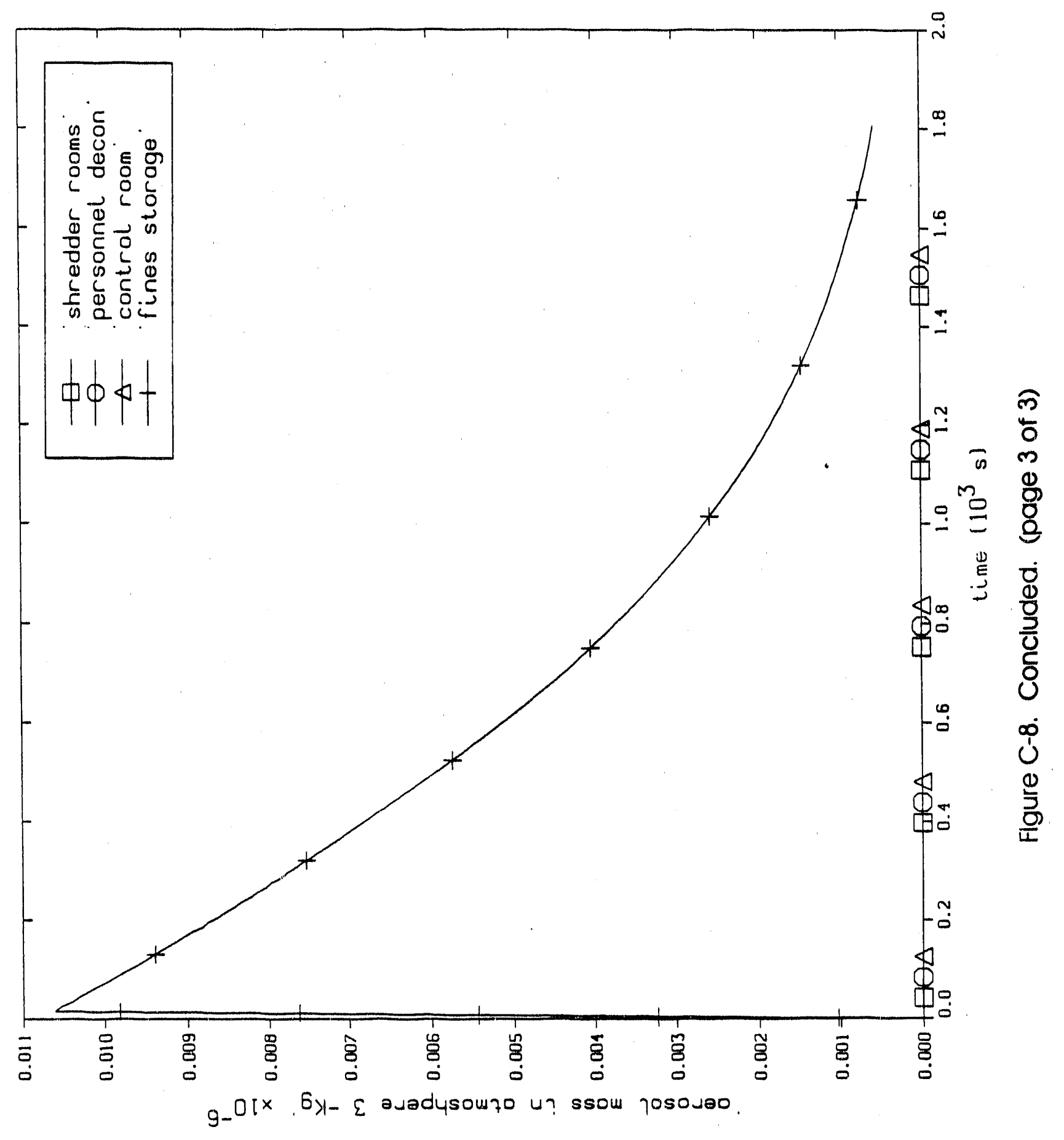




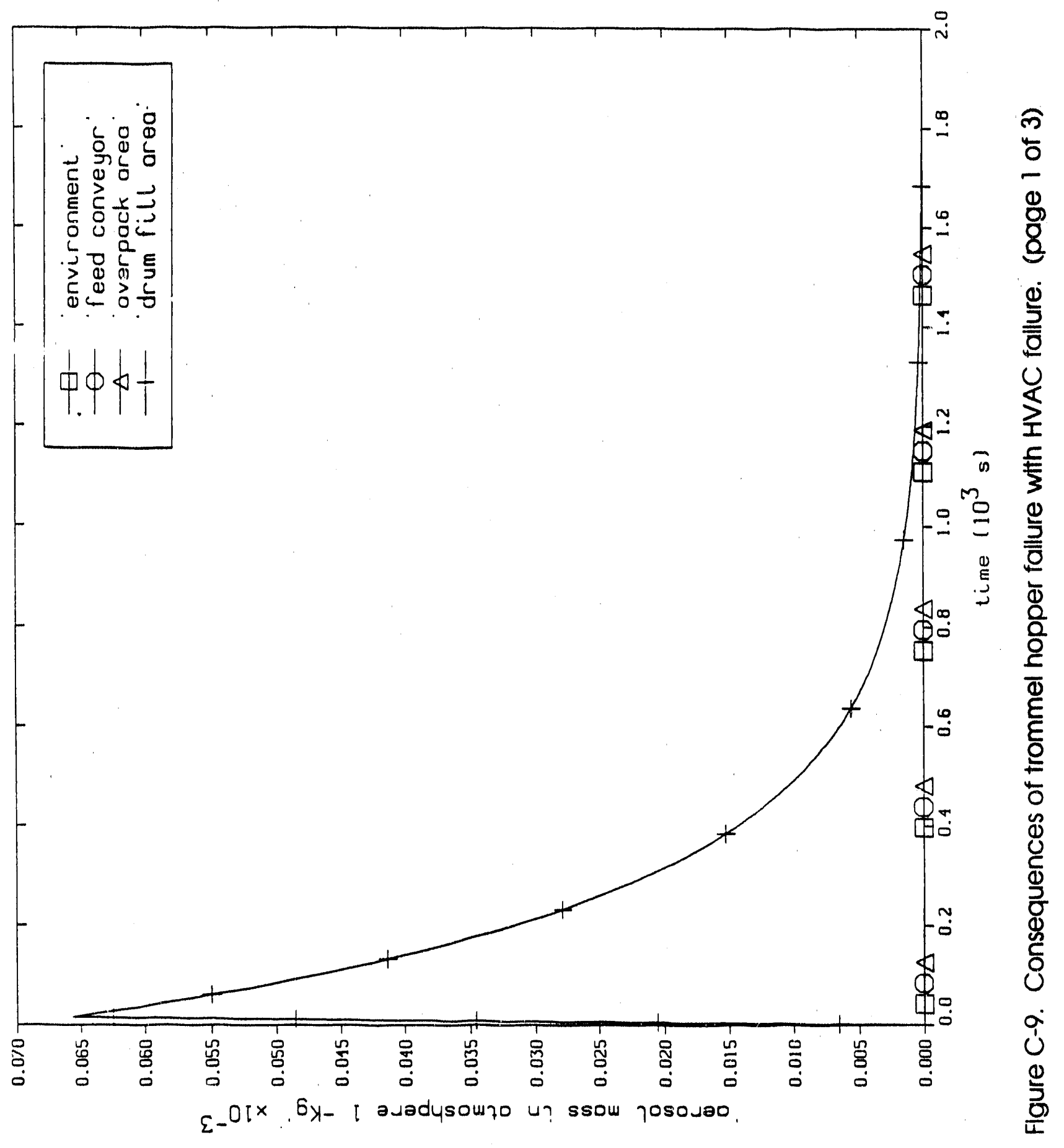

C-26 


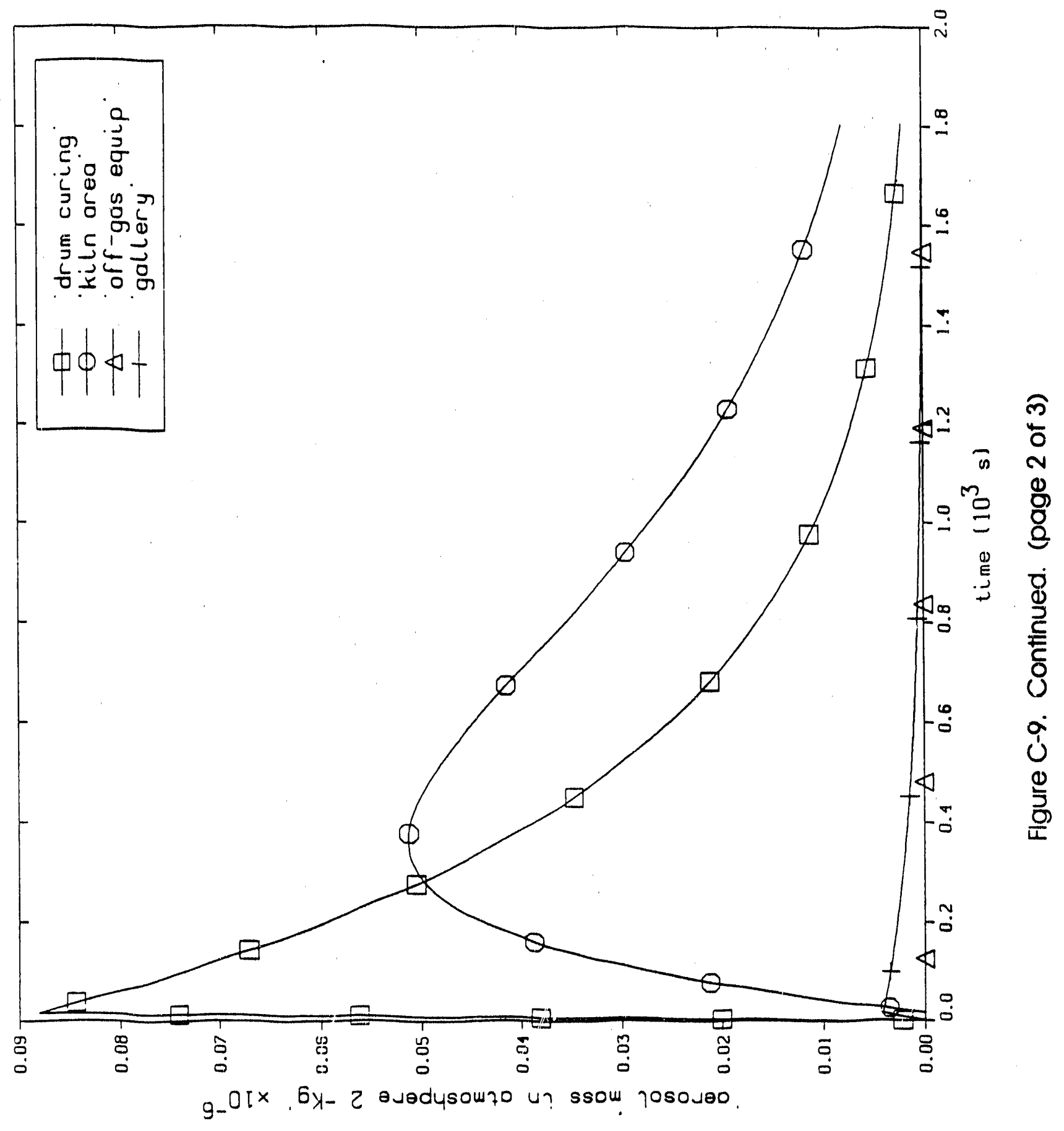

C-27 


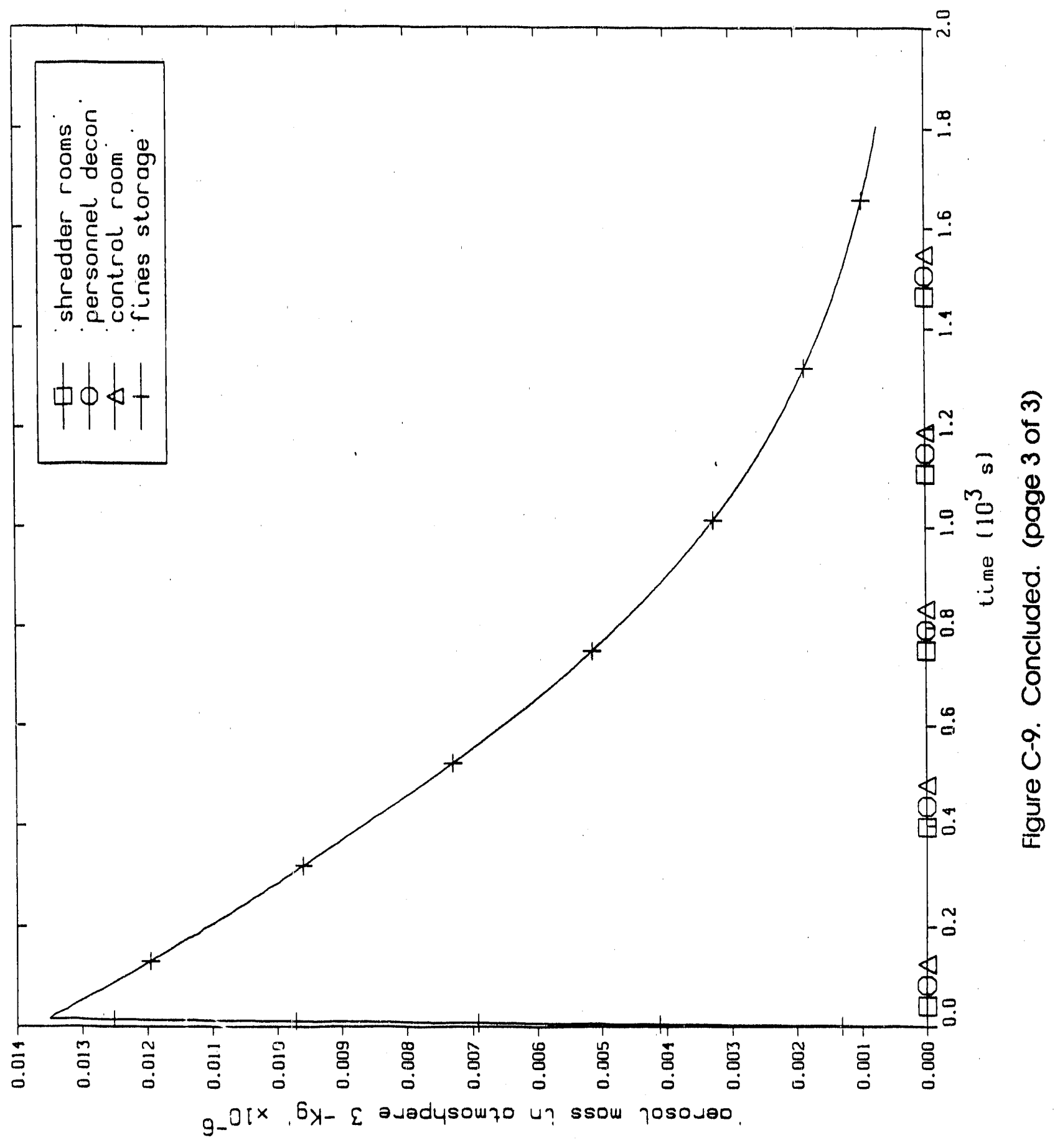

C-28 


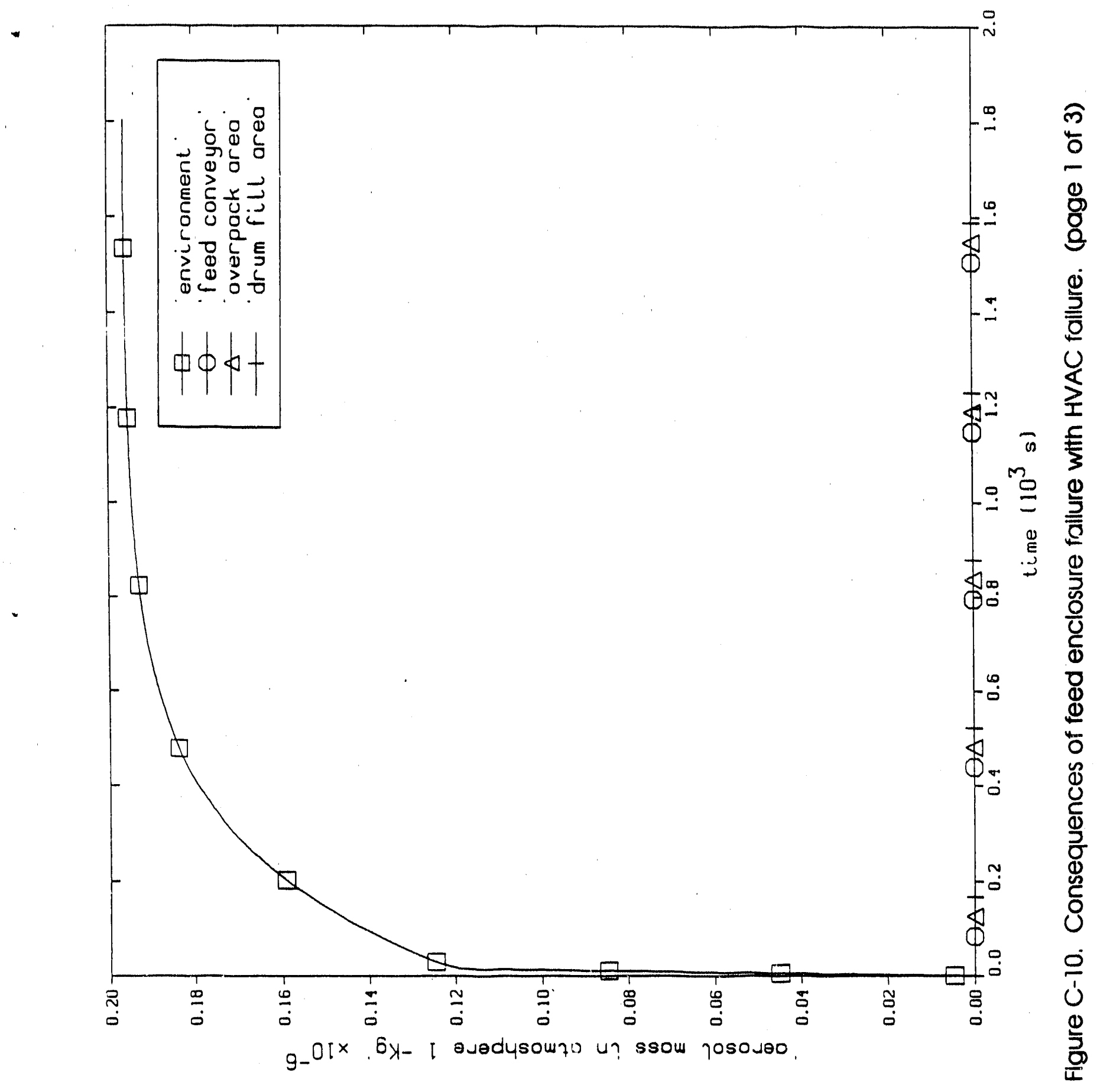




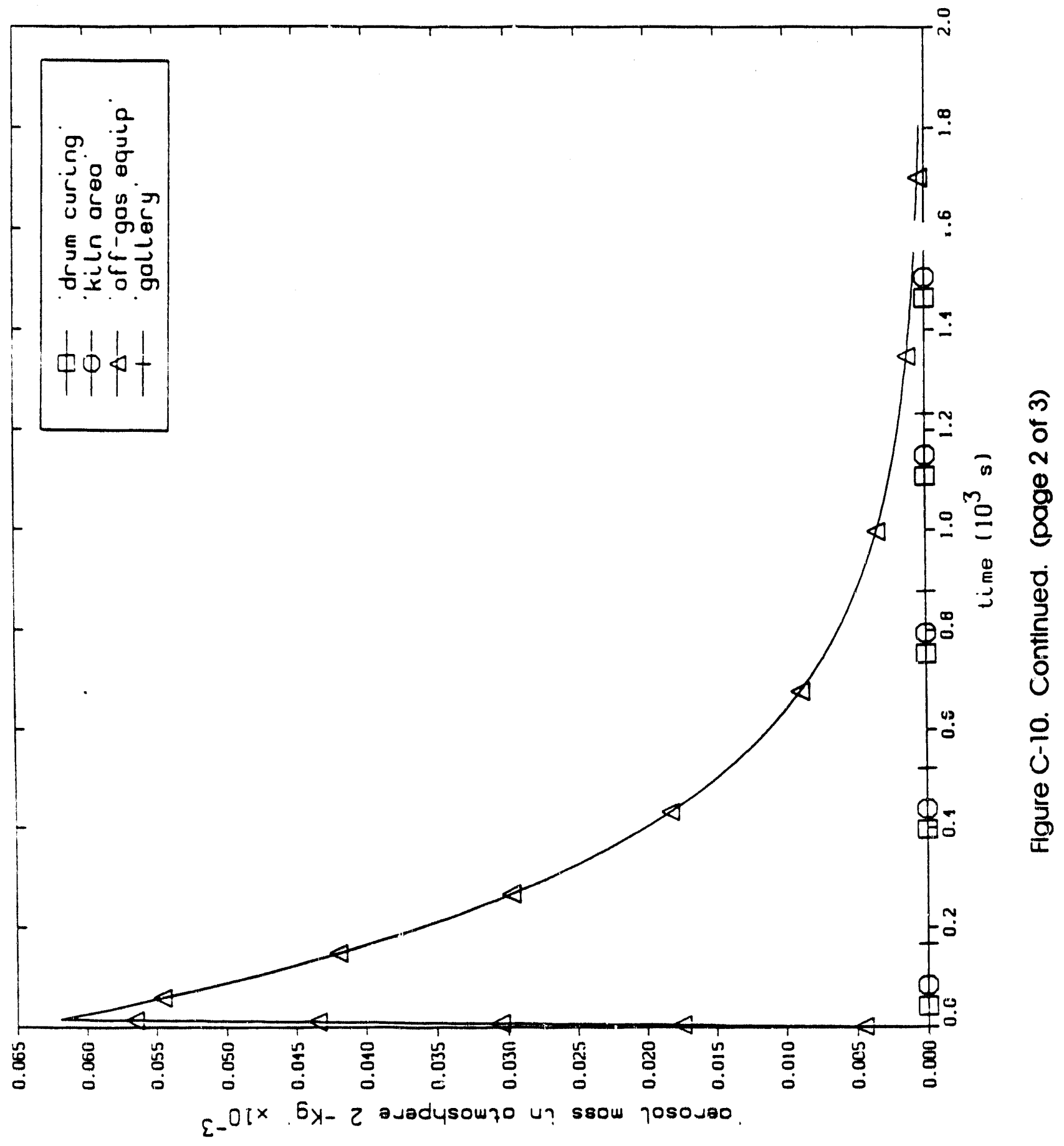




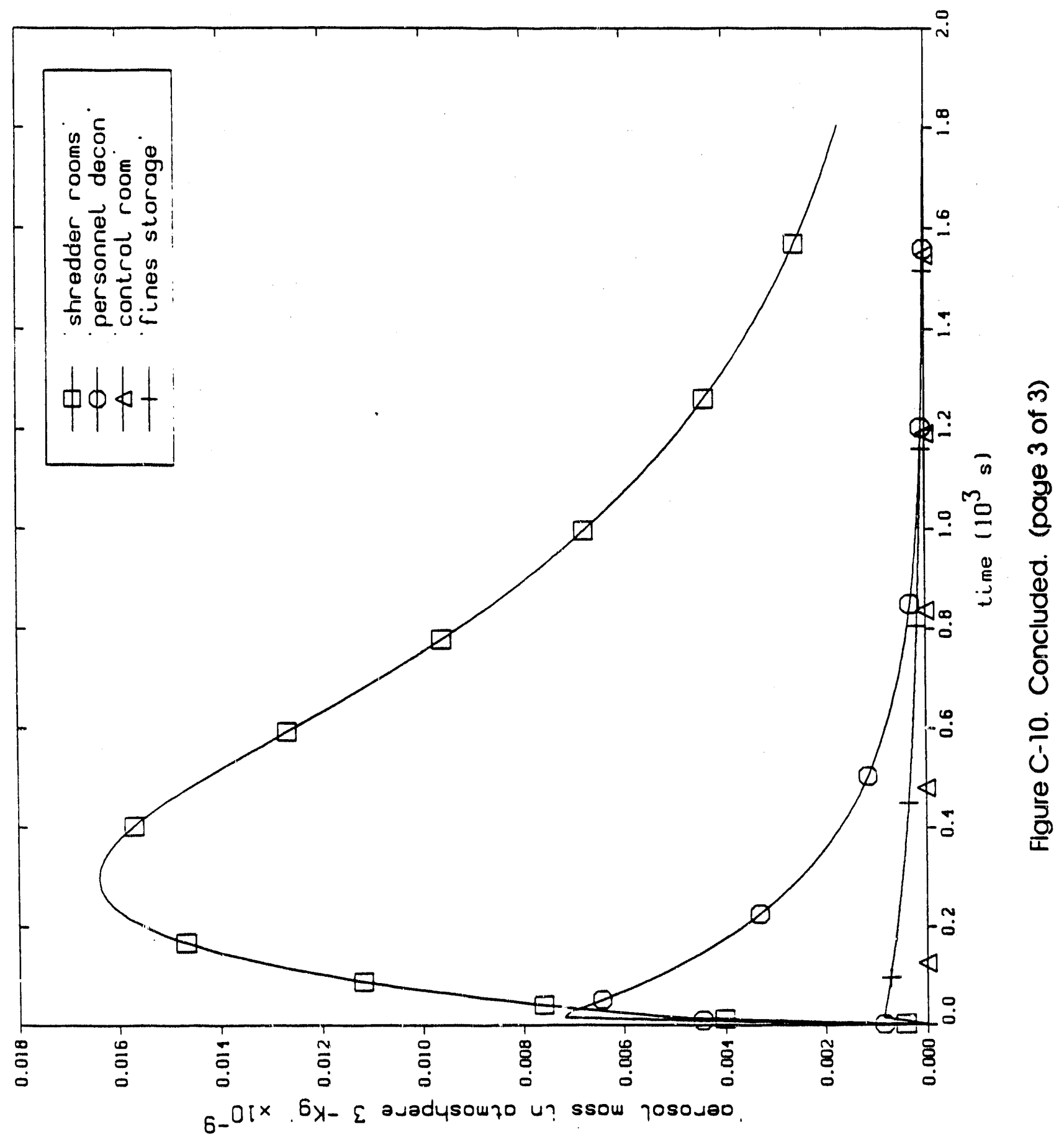

C-31 


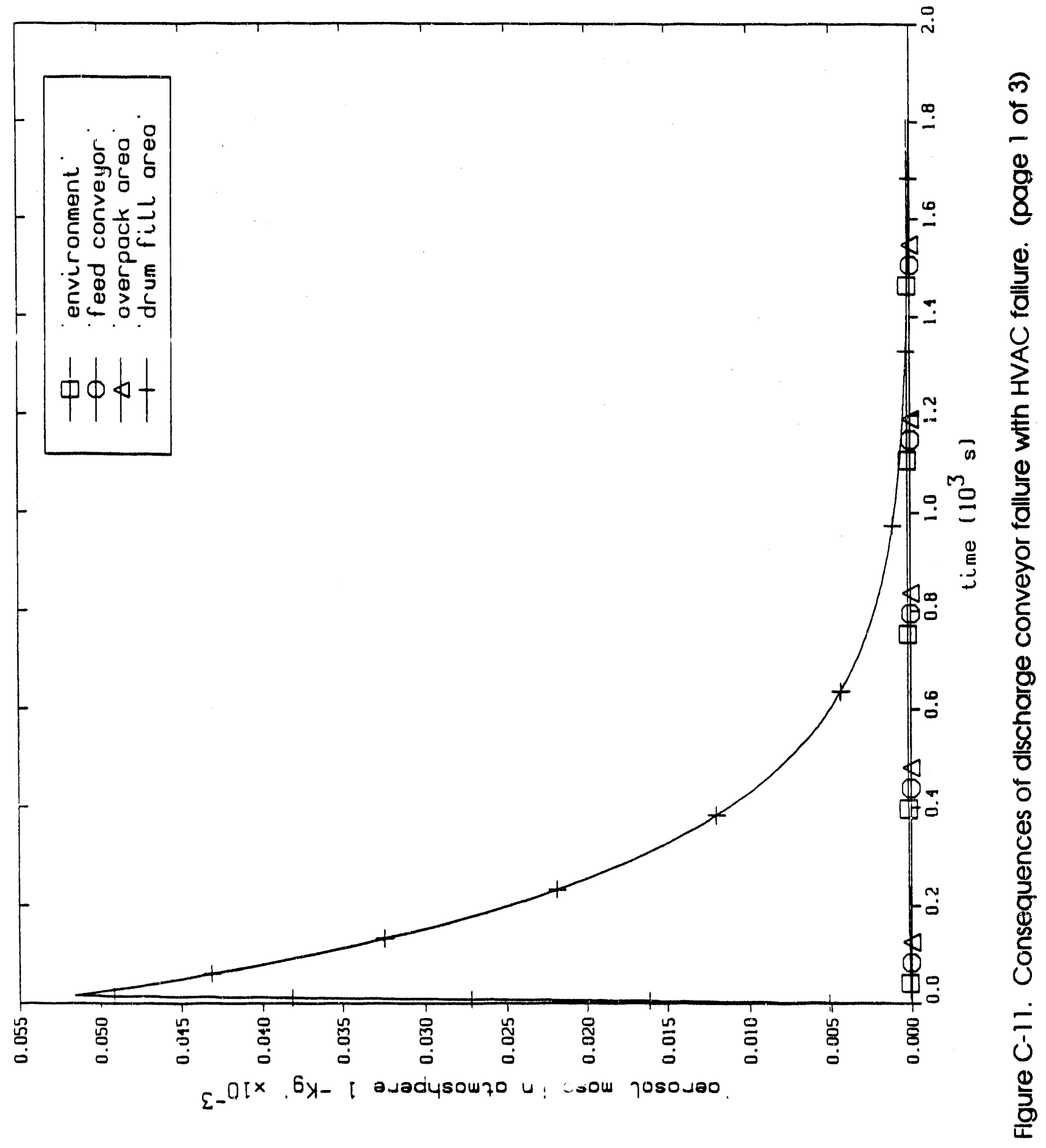

C- -32 




\section{C- -33}




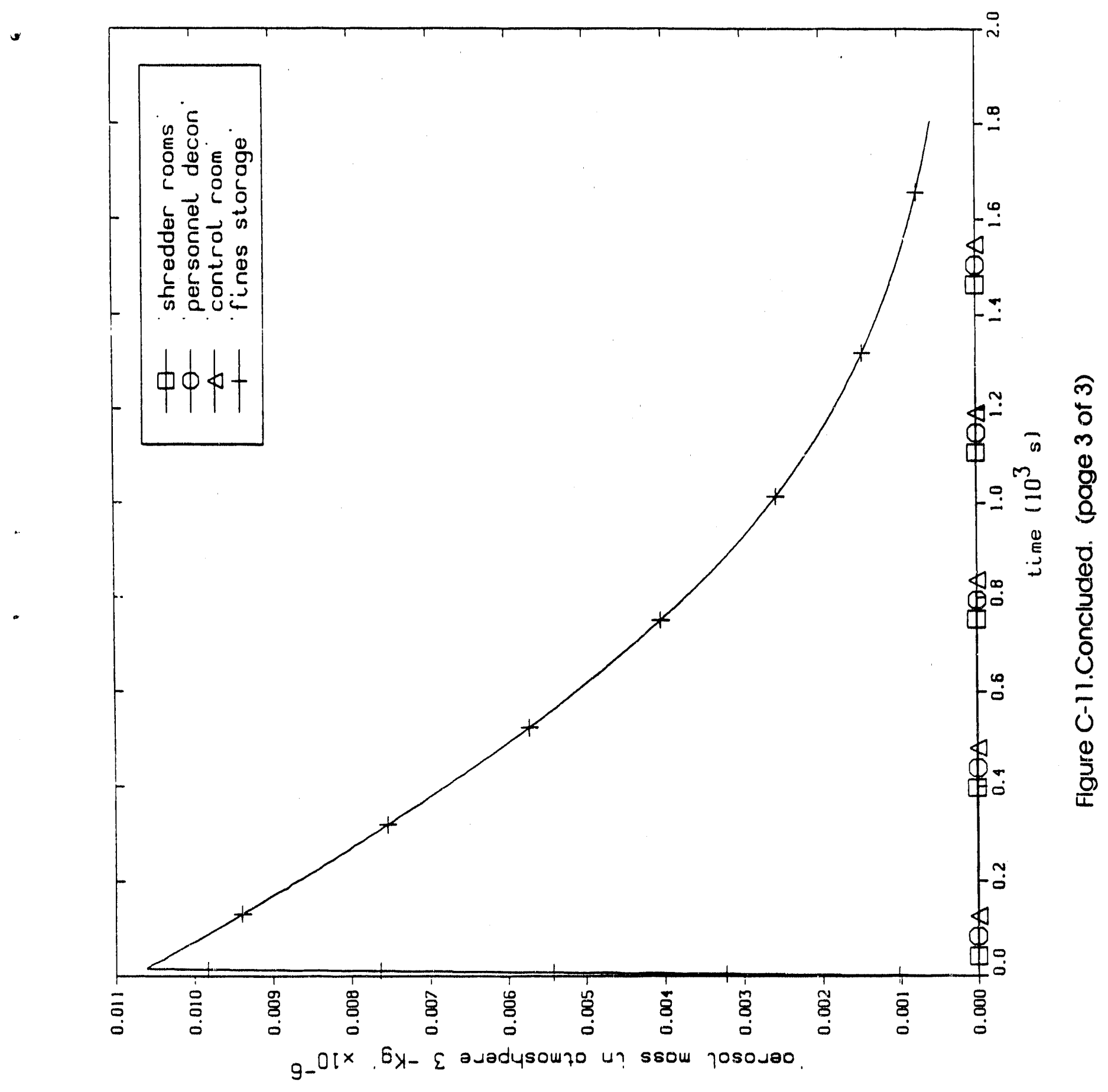






C- -35 


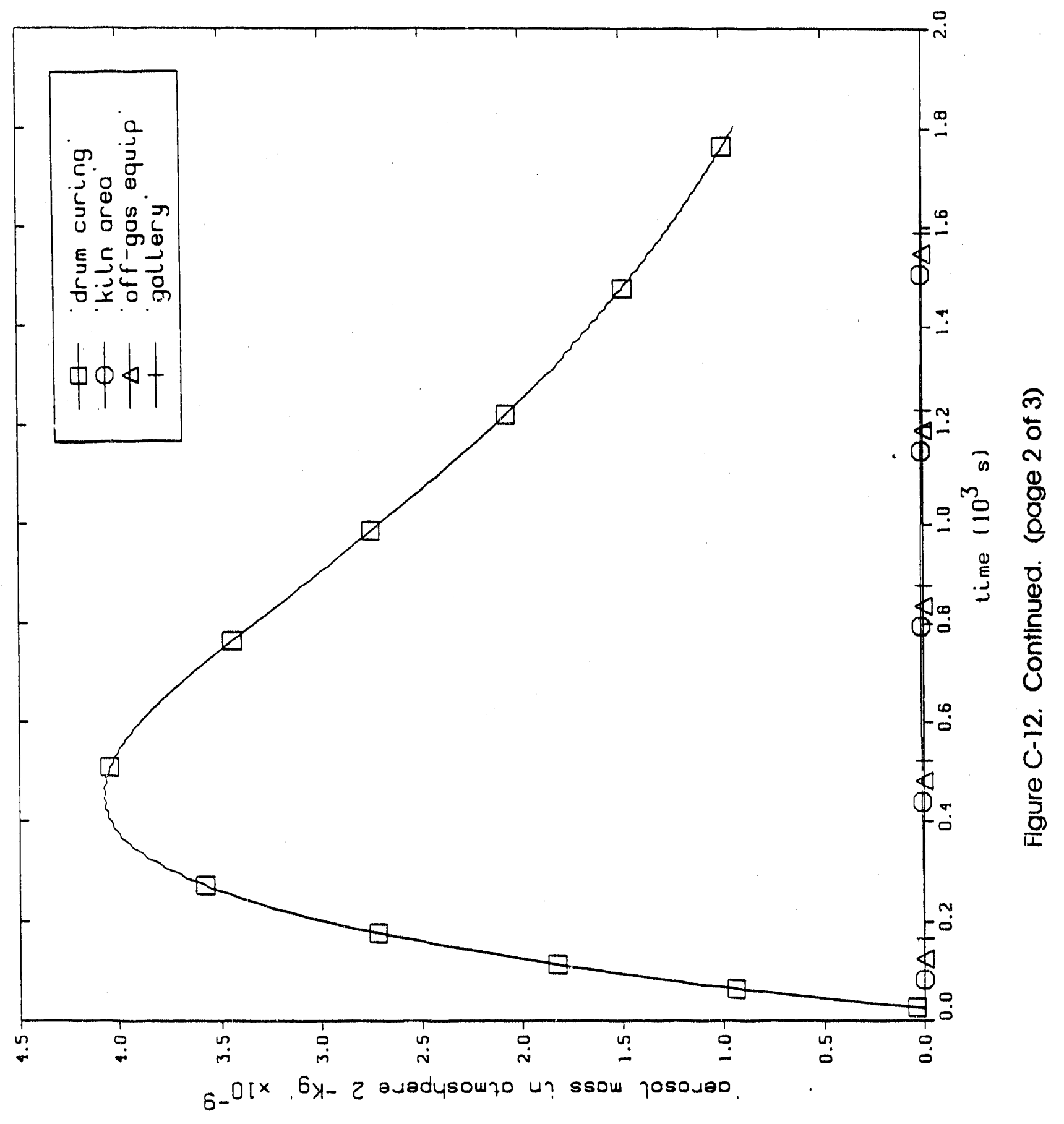








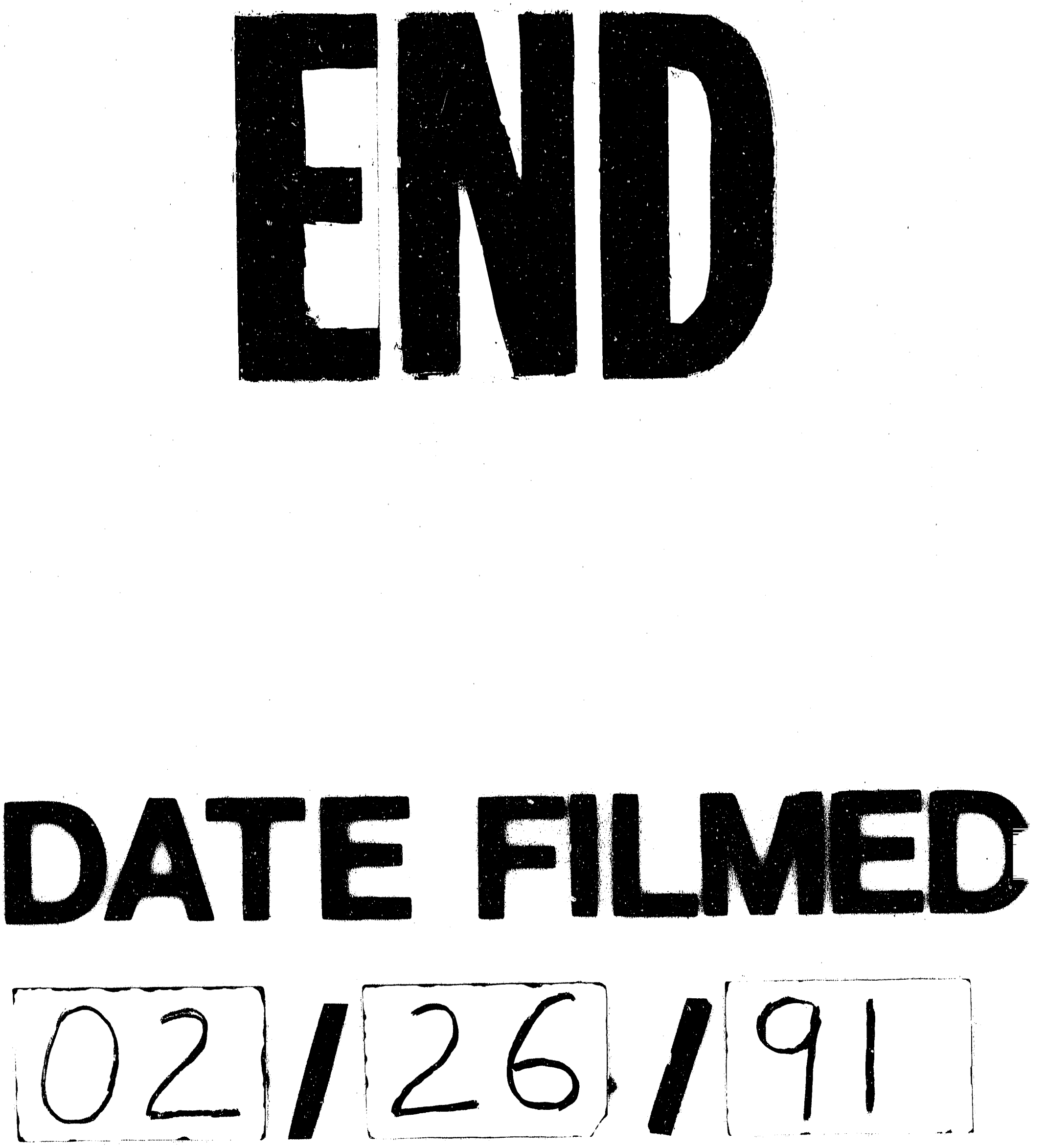
